\title{
PRAIAPAISAGEM: \\ A REDESCOBERTA DO ESPAÇO PÚBLICO NA PRAIA
}

\author{
Beachscape: \\ The Rediscovery of Public Space on the Beach
}

Tese apresentada ao Programa de Pós-graduação da Faculdade de Arquitetura e Urbanismo da Universidade de São Paulo para a obtenção do título de Doutor em Arquitetura e Urbanismo

Área de concentração: História e Fundamentos da Arquitetura e do Urbanismo. Linha de pesquisa: Espaço Público, Arte \& Arquitetura

Orientador: Prof. Dr. Agnaldo Aricê Caldas Farias 
AUTORIZO A REPRODUÇÃO E DIVULGAÇÃO TOTAL OU PARCIAL DESTE TRABALHO, POR QUALQUER MEIO CONVENCIONAL OU ELETRÔNICO, PARA FINS DE ESTUDO E PESQUISA, DESDE QUE CITADA A FONTE.

E-MAIL DO AUTOR: eduardo.aquinolumanitoba.ca

Aquino, Eduardo Silvério de

A657p Praiapaisagem: a redescoberta do espaço público na praia /

Eduardo Silvério de Aquino. -- São Paulo, 2014.

238 p. : il.

Tese (Doutorado - Área de Concentração: História e

Fundamentos da Arquitetura e Urbanismo) - FAUUSP.

Orientador: Agnaldo Aricê Caldas Farias

1.Paisagem urbana 2.Arquitetura 3.Planejamento territorial urbano 4.Arte 5.Espaço público 6.Arte pública 7.Praia 8.Superfície I.Título 


\section{AGRADECIMENTOS}

A Universidade de Manitoba pelos dois períodos sabáticos que permitiram a realização deste trabalho, e ao escritório do decano David Witty da Faculdade de Arquitetura da Universidade de Manitoba pelo subsídio de viagem durante este ciclo de estudo. Ao Plug In Institute of Contemporary Art em Winnipeg, que publicou o piloto desta investigação.

Sou muito grato ao professor Agnaldo Farias pelo apoio inquestionável à esta pesquisa, pelo seu acompanhamento astuto, pelos momentos extraordinários nas suas aulas, mas acima de tudo pela carinhosa amizade, o que influenciou e motivou este trabalho. Aos colegas Fernanda Fernandes e David Sperling pela atenção cuidadosa e pelo feedback precioso. Aos professores Ricardo Marques de Azevedo e Regina Meyer pelos momentos inestimáveis de aprendizado. Aos amigos Fernando de Mello Franco, Paulo Mendes da Rocha e Alexandre Delijaicov pelas conversas e colaborações durantes estes anos todos. A Eloísa Aquino, por tantas sugestões e pelo cuidadoso trabalho de edição. A Karen Shanski, que me fez ver uma Copacabana que eu não conhecia, o que resultou neste projeto.

Para papai e mamãe, que sempre me levaram à praia.

Para Juca e Zeca, quem eu sempre levarei. 


\section{SUMÁRIO}

006

1_RESUMO | ABSTRACT

008

2_INTRODUÇÃO: A PRAIA, ARTE E ARQUITETURA

008 I_A condição-praia: a transição do objeto para a relação

018 II_A redescoberta da praia como espaço público

020 III_ De scapes à praiapaisagem

022 IV_Antecedentes

035 3_ TRÊS DESENHOS: A QUEBRA DOS LIMITES DO ESPAÇO NA CONFLUÊNCIA ENTRE ARTE, ARQUITETURA E PAISAGEM

035 I_Le Cabanon: a praia como coisa

039 II_Delirium Ambulatorium: a praia como modus operandi

045 III_Barravento: a praia como narrativa

051 4_A PASSAGEM DO ATELIER PARA A RUA: DO OBJETO PARA A SUPERFÍCIE

051 I_ 0 crescimento das cidades e as práticas artísticas

055 II_ Habitando a metrópole: da rua à praia

061 III_ Do espaço da casa para o espaço da rua

065 IV_Rompimento interior

069 5_SITUACIONISMOS E A ATITUDE "PÚBLICA"

069 I_Situacionismo como resistência

076 II_ Os anos 1960 e a descoberta da rua

080 III_A rua como prática contemporânea

089 IV_A performance do dia-a-dia: ampliando o campo ampliado

094 6_EPISTEMOLOGIA DA SUPERFÍCIE: DO OBJETO PARA A PRAIA

097 I_ A superfície do objeto

107 II_ A superfície dura do objeto (o edifício)

109 III_ A superfície mole do objeto (a praia)

112 IV_Superfície-mundo: a manifestação de uma outra vida

122 7_ COPACABANA COMO MODELO URBANO

122 I_Copacabana: a praia e o mito

134 II_ A praia de Copacabana e Roberto Burle Marx

142 III_ 0 espaço público de Copacabana 


\section{8_ ESPAC̣O-VIDA DA PRAIA: DA SUPERFÍCIE PARA A RELAC̣ÃO}

156 I_Praia como cidade: Gesamtkunstoberfläche

159 II_ A superfície da cidade

162 III_Reprodução de poeira: total disponibilidade do solo urbano

165 IV_Gramática de superfície I Gramática profunda

$174 \quad V_{-}$A s superfície da praia

179

\section{PRAIAPAISAGEM}

179 I_Arquitetura como praia

191 II_Condições \& dispositivos

196 III_ Procedimentos de desenho

Urbanismo mão aberta / Reinventar o programa / Superfície indeterminada / Ocupação garantida / Superfície ampliada / Superfície inclinada / Materialidades maleáveis, materiais futuros / 0 desenho da superfície / Poetizar o urbano / Arte pública / Repensar a infraestrutura

223 IV_ Leça de Palmeira I 0 encontro derradeiro entre arquitetura e a praia

\section{10_REFERÊNCIAS BIBLIOGRÁFICAS}

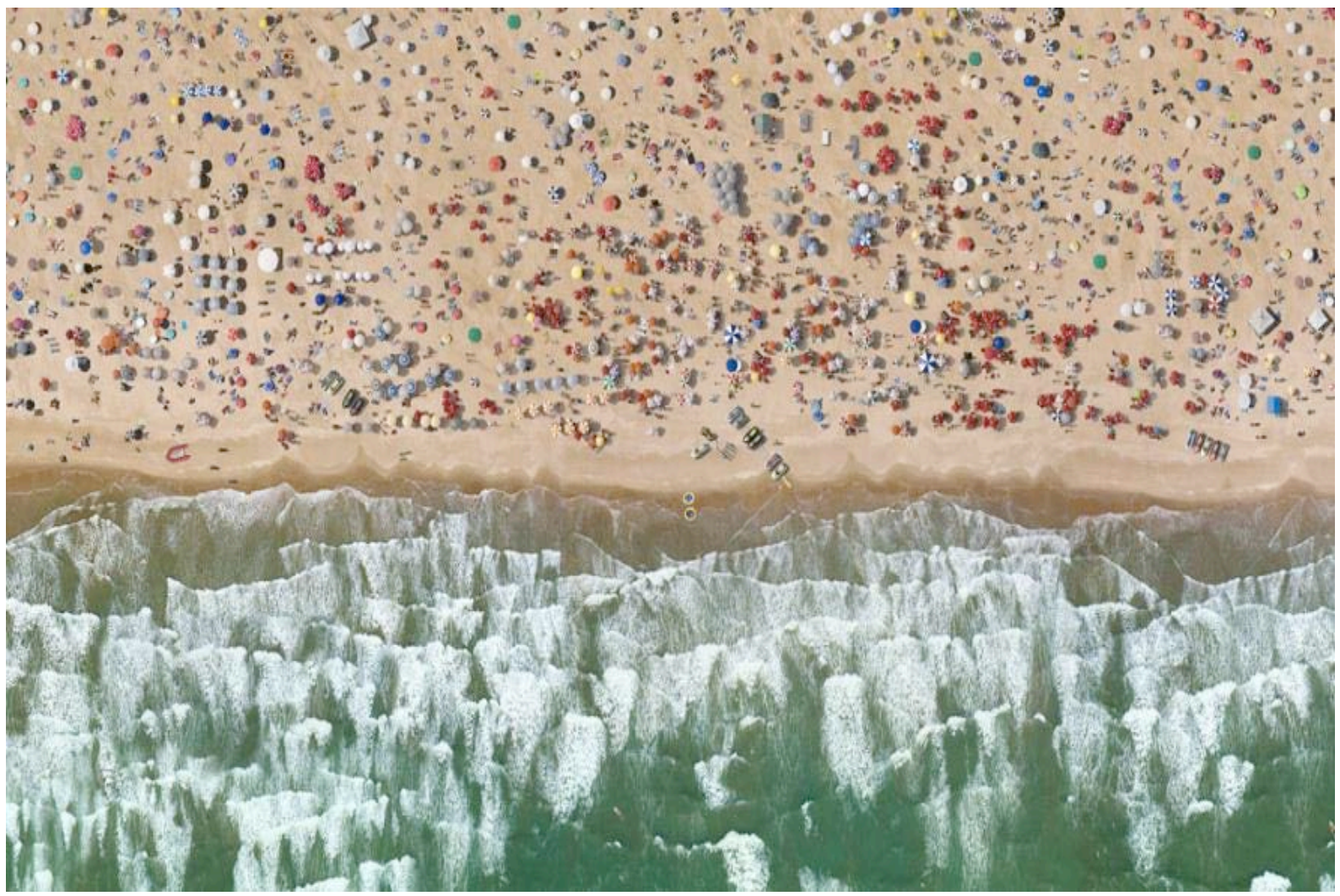

Cássio Vasconcellos, Praia (colagem): “Imaginei uma praia superpovoada, como seria em uma cidade grande." (2008-11) 


\section{1_RESUMO}

A praia urbana circunscreve um tipo de espaço dotado de um mecanismo flexível para a negociação entre pessoas e lugares, economias e culturas, arquiteturas e cidade, diferenciandose de estruturas urbanas mais estáveis definidas por edifícios ou infraestruturas.

A organização da cidade e a valorização da experiência urbana pode encontrar mais recursos nos fluxos da praia. Fluidez, mobilidade, feedback espontâneo e não-linearidade oferecem alternativas para a estabilidade, a previsibilidade, ou a racionalidade da cidade. Praiapaisagem identifica um espaço caracterizado por uma superfície dinâmica, onde as ações humanas estão em constante transformação, gerando um campo de possibilidades em face à estagnação da vida urbana.

Com o olhar situado na complexa experiência da praia este estudo estabelece como hipótese uma matriz para novas direções do desenho urbano como tática espontânea, contestando as convenções da prática tradicional. A praia é aqui entendida não como tipologia, mas como um sistema complexo, integrante da cidade, promotor e organizador da vida, expandindo-se e encolhendo-se simultaneamente aos experimentos humanos em constante movimento. A partir do cruzamento entre arte e arquitetura, e considerando o fenômeno da superfície como fundamento, uma epistemologia é proposta: o mapeamento da transição do objeto da arte (a obra de arte) e do objeto da arquitetura (o edifício) dos seus estados autônomos para o ambiente urbano, tanto em práticas artísticas como em arquitetura indicando uma rede de relações.

Usando como referência algumas atitudes específicas das vanguardas do século 20 o trabalho aponta para uma série de estratégias de reordenação da cidade contemporânea e das suas práticas afins. Empenhadas relacionalmente no locus da praia, tais práticas podem ser categorizadas em duas ordens: uma atua diretamente no âmbito da praia; a segunda, apreendendo-se das dinâmicas da praia, volta-se para a cidade, e utilizando-se do conceito de praiapaisagem como estratégia, busca a proposição de um outro desenho, um outro espaço público.

Palavras-chave: Arquitetura; urbanismo; arte \& arquitetura; escultura; espaço público; arte pública; superfícies; praia; paisagem. 


\section{1_ABSTRACT}

The urban beach circumscribes a type of space endowed with a flexible mechanism for negotiation between people and places, economies and cultures, architectures and the city, differentiating from more stable urban structures defined by buildings or infrastructure. The city organization and enhancement of the urban experience can find more resources in the fluxes located on the beach. Fluidity, mobility, spontaneous feedback, and nonlinearity offer alternatives to the stability, predictability, and rationality of the city. Beachscape identifies a territory characterized by a dynamic space, where human actions are in constant transformation, generating a field of possibilities in the face of the stagnation of urban life.

Considering the complex situation of the beach experience this study establishes the hypothetical matrix for new directions of urban design as spontaneous tactics, challenging the conventions of traditional practice. The beach here is understood not as typology, but as a complex system, an integral part of the city, promoter and organizer of life, expanding and shrinking while human experiments are in constant motion. Establishing a crossing between art and architecture, and considering the surface as a phenomenon, the work proposes an epistemology: mapping the transition from the art object (the artwork) and the object of architecture (the building) from its autonomous states toward the urban environment, both in artistic practices as in architecture, as a form to indicate a network of relationships.

With reference to some specific attitudes of the 20th century vanguard the work points to a number of strategies for reordering the contemporary city and its related professional practices. Relationally engaged in the locus of the beach, such practices can be categorized into two types: one operates directly on the beach; the second, seizing upon the dynamics of the beach, looks back to the city, and through the concept of beachscape envisions a strategy to propose another design, another public space.

Keywords: architecture, urbanism, art \& architecture, sculpture, public space; public art; surfaces; beach; landscape. 


\section{2_INTRODUÇÃO: A PRAIA, ARTE E ARQUITETURA}

Quem vem pra beira do mar, ai

Nunca mais quer voltar, ai

Quem vem pra beira do mar, ai

Nunca mais quer voltar

Andei por andar, andei

E todo caminho deu no mar

Andei pelo mar, andei

Nas águas de Dona Janaína

A onda do mar leva

A onda do mar traz

Quem vem pra beira da praia, meu bem

Não volta nunca mais ${ }^{1}$

$$
\text { - Dorival Caymmi }
$$

Você foi moleque de praia, não?

Fui. Passava vinte e quatro horas por dia, por assim dizer, na praia onde eu jogava pelada. Eu tinha mesmo loucura pela praia e gostava muito do cheiro do mar. ${ }^{2}$

$$
\text { - Nelson Rodrigues }
$$

Quando você era uma criança você sempre quis ser um arquiteto?

Não, nunca o pensamento me passou pela cabeça.

Quando eu era jovem estava mais preocupado em divertir-me.

Eu sempre fui à praia. ${ }^{3}$

- Paulo Mendes da Rocha

\section{I_A condição-praia: a transição do objeto para a relação}

Vamos à praia? A praia é o tema central deste estudo. A hegemonia da praia no universo brasileiro é tão presente e predominante no âmbito cultural e do lazer que impregna o inconsciente coletivo. Não podemos negar a fascinação que a praia tem no imaginário daqueles que tem acesso à praia, mas também, e até com mais intensidade, para aqueles que apenas imaginam a praia mas ainda não tiveram a oportunidade de encontrá-la. No contexto brasileiro talvez o encontro mais intenso deu-se nas praias do Rio de Janeiro. Aqueles que

\footnotetext{
1 Dorival Caymmi, “Quem vem pra beira do mar". Disponível em: http://letras.mus.br/dorivalcaymmi/688632. Acesso em: 12 de julho de 2013.

${ }^{2}$ Nelson Rodrigues, "Entrevista para o Ciclo de Teatro Brasileiro do Museu da Imagem e do Som" (Walmir Ayala, José Lino Grunewald, Fausto Wolff, Otto Lara Resende e Hélio Pellegrino). Disponível em: <http://www.nelsonrodrigues.com.br/site/comnelson_det.php?ld=16>. Acesso em: $14 \mathrm{de}$ dezembro de 2013.

${ }^{3}$ Paulo Mendes da Rocha, "Paulo Mendes da Rocha Interview”. Disponível em: <http://www.designboom.com/eng/interview/rocha.html . Acesso em: 14 de abril de 2012, tradução nossa.
} 
originalmente habitavam a paisagem carioca talvez desconhecessem a magnitude do lugar até pela sua própria familiaridade. Mas imaginamos que a primeira chegada na Baía de Guanabara pelos europeus ao confrontarem esta paisagem exuberante foi de um impacto enorme: os grandes penedos, a floresta tropical e o mar. A maior evidência desta intensidade inicial é o fato de tantas gentes terem elegido o Rio como um lugar para ficar. Esta escolha perdura até os dias de hoje evidenciada pelo crescimento populacional, com a insistência da favela e da ocupação dos morros cariocas, da permanência dentro da malha urbana da cidade. Outra medida do impacto de Copacabana no imaginário seria a reputação internacional do Rio de Janeiro como um destino turístico, por ser um "paraíso urbano tropical”, reconhecendo este conjunto paisagístico-urbano como excepcional. Aqui o sonho do paraíso tropical combinou com o desejo da metrópole, com o ideal de uma vida equilibrada, pautada na independência econômica, mas bem próximo dos maiores prazeres da vida e da natureza. Este desejo de ficar é expressado tão enfaticamente por Caymmi: Quem vem pra beira do mar, ai / Nunca mais quer voltar, ai / Quem vem pra beira do mar, ai / Nunca mais quer voltar. Caymmi comprovou esta realidade com a sua própria vida. Nascido e criado em Salvador elegeu o Rio como destino, tendo vivido em Copacabana a maior parte do tempo, até a sua morte.

Dorival Caymmi, como todos os outros cariocas, assumiu o Rio no seu próprio corpo com um jeito todo particular de ser que está envolto com esse desejo de viver na beira do mar. O chinelo de dedo, o jeito de andar, a sociabilidade espontânea, a preguiça de um sábado de manhã, a música na rua, o fulano que enche o saco, a conversa na calçada, o grito no trânsito, o pular do ônibus, o bar na esquina, e mais do que isso: o boteco - este símbolo carioca tão consequente quanto a praia. Estes são um dos poucos trejeitos encontrados nos cariocas. E como esse jeito de ser é diretamente influenciado pela praia? E como a praia contribuiu para tal formação? Com certeza uma outra noção de tempo foi introduzida, a começar pelo andar na areia fofa, pois é impossível andar rápido na areia fofa. Tem os cheiros da cidade e no caso da proximidade com a praia especialmente a maresia. A maresia estende a amplidão do oceano até as bordas das ruas. Tem também o sustentar do corpo, o estar no espaço no próprio corpo e em direta relação com a experiência da praia. Basta observarmos aqueles que não convivem diretamente com a beira do mar para sentirmos a diferença: o paulista acelera, o carioca moleja. 


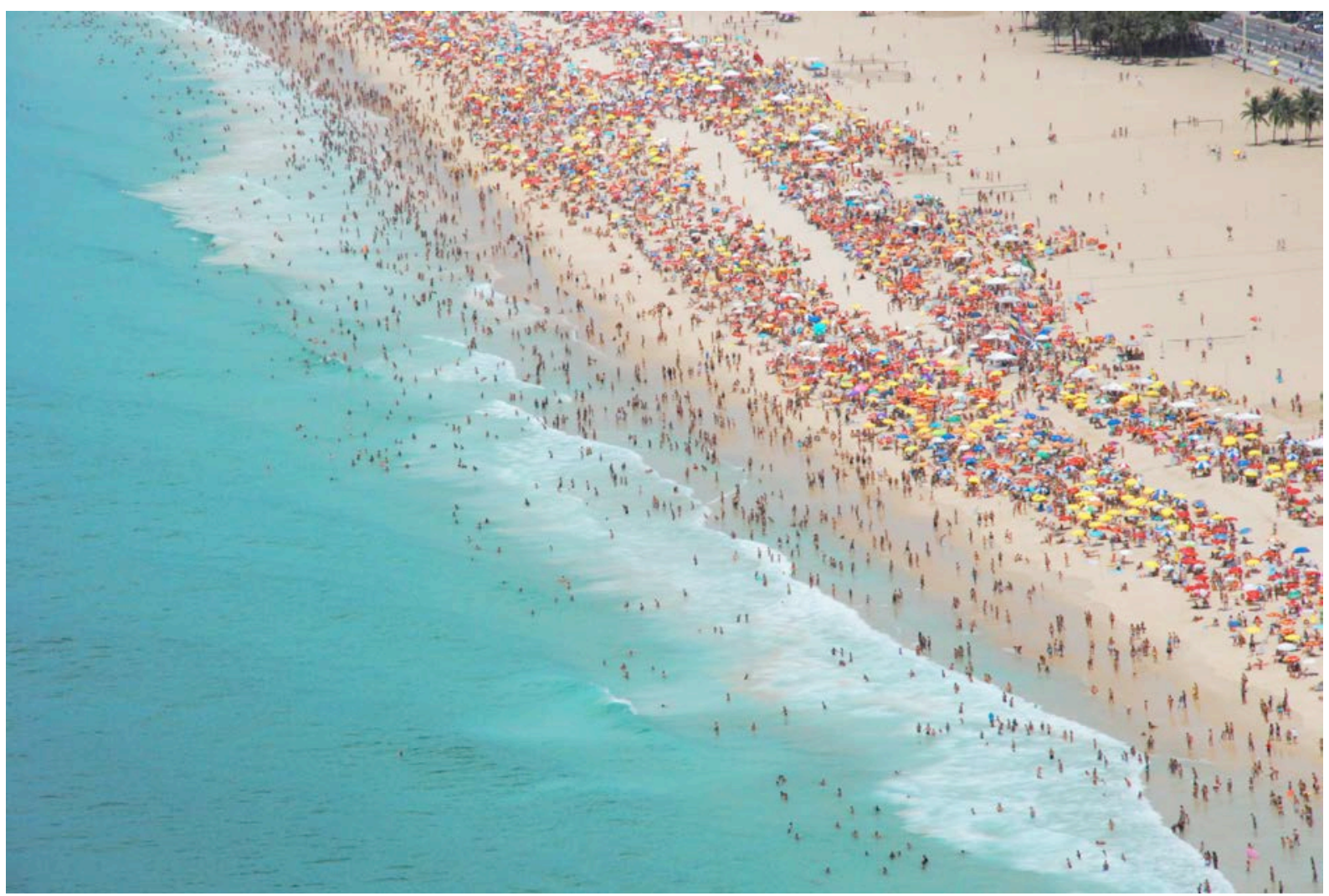

Flávia Costa, Copacabana

A praia desacelera o dia-a-dia e dita um novo ritmo de tempo. O carioca portanto é mais devagar, mais tranquilo. As centenas senão milhares de visitas à praia condicionaram a maneira de intuírem o corpo, a tal ponto que na sua nudez incorruptível chegam a aceitá-lo simplesmente da maneira como o é. É esta aceitação incondicional que informa uma outra maneira de andar, a postura do corpo em relação ao outro, como que a sua própria inconsciência confirmasse a informalidade das trocas, pois aquilo que se comunica, aquilo que se partilha é de fato superior a qualquer aparência física - o jeitinho carioca. O mesmo ocorre quando o carioca ocupa o espaço público, invadindo recintos e quebrando normas no limite da tolerância alheia. Olham-se um para o outro e silenciosamente desviam-se o olhar como uma forma de perdão, de aceitação. Não necessariamente como se qualquer comportamento fosse aceitável, mas na compreensão dos limites alheios é que se acolhe o mútuo engajamento num espaço compartilhado - se eu deixo você fazer, você também me deixa, e assim estamos de acordo. Tais condutas, tão cariocas no jeito de serem, são inconscientemente e até espontaneamente influenciadas pela experiência da praia.

O corpo no espaço, ou a presença da praia na definição completa do corpo, estabelece pelo seu inverso uma série de novas relações, consigo e com outros. Neste caso deixamos a 
abordagem antropológica ou social num segundo plano para nos aproximar de um processo de filtragem pelas vias da cidade, da própria história da evolução da cidade como forma de disciplina. Assim nos detemos no urbanismo e na experiência artística como capacidades estruturadoras da experiência urbana e na arquitetura resultante para mapearmos uma melhor compreensão do corpo social coletivo e do espaço público. Tal abordagem não poderia limitar-se aos aspectos físicos da experiência urbana, mas sim combiná-la com as mitologias do lugar, das expressões poéticas, daquilo que imprime significados humanos na expressão e vivência de cada lugar. Então qual seria o papel da praia na construção de um diálogo entre o urbanismo, a arquitetura e arte? Como a experiência da praia alimenta os conhecimentos específicos de tais disciplinas, e como elas ajudam a explicar o fenômeno da praia?

Mais recentemente, com o sucesso da introdução de uma praia nas bordas do Rio Sena em Paris (Paris Plage, a partir de 2002), a ideia da praia urbana espalhou-se pelo mundo, e hoje podemos encontrar situações semelhantes de praias urbanas que foram introduzidas em Roterdã, Copenhague ou Toronto. Mas por que então a praia? A praia é um território fértil, onde, através de observações das suas situações diversas, poderíamos identificar um diagnóstico do objeto da praia, da situação-praia e, neste processo de compreendê-la na sua riqueza, nos aproximar de melhores práticas para a produção do desenho. ${ }^{4}$ Mas aqui a praia subsiste também como conceito, que denominamos de praiapaisagem. Praiapaisagem prioriza as condições que criam a existência da praia como potencial de desenho. A intenção principal aqui é recuperar a praia como um fenômeno esquecido na discussão da cultura geral, mais especificamente no diálogo crítico da produção da arquitetura. A praia urbana está localizada num segundo plano quando consideramos as nossas cidades e a produção contemporânea, desamparada pela consciência geral de certa forma, apesar da sua influência significativa na formação do imaginário brasileiro.

Um outro fenômeno identificado aqui seria a presença de um sentido-praia em outras manifestações culturais não necessariamente vinculadas à praia através de uma relação direta. Tais situações acumulam qualidades observadas na praia - a extensão da superfície, o dinamismo coletivo, a atmosfera de ócio e prazer, etc. - sem estarem presentes na paisagem específica da praia em si. Referimo-nos aqui a tais manifestações como projetos, projetos-praia. Neles podemos sentir uma presença, um espírito, uma experiência análoga à praia. Não

\footnotetext{
4 "Desenho" no sentido de desejo: o que queremos para as nossas cidades?
} 


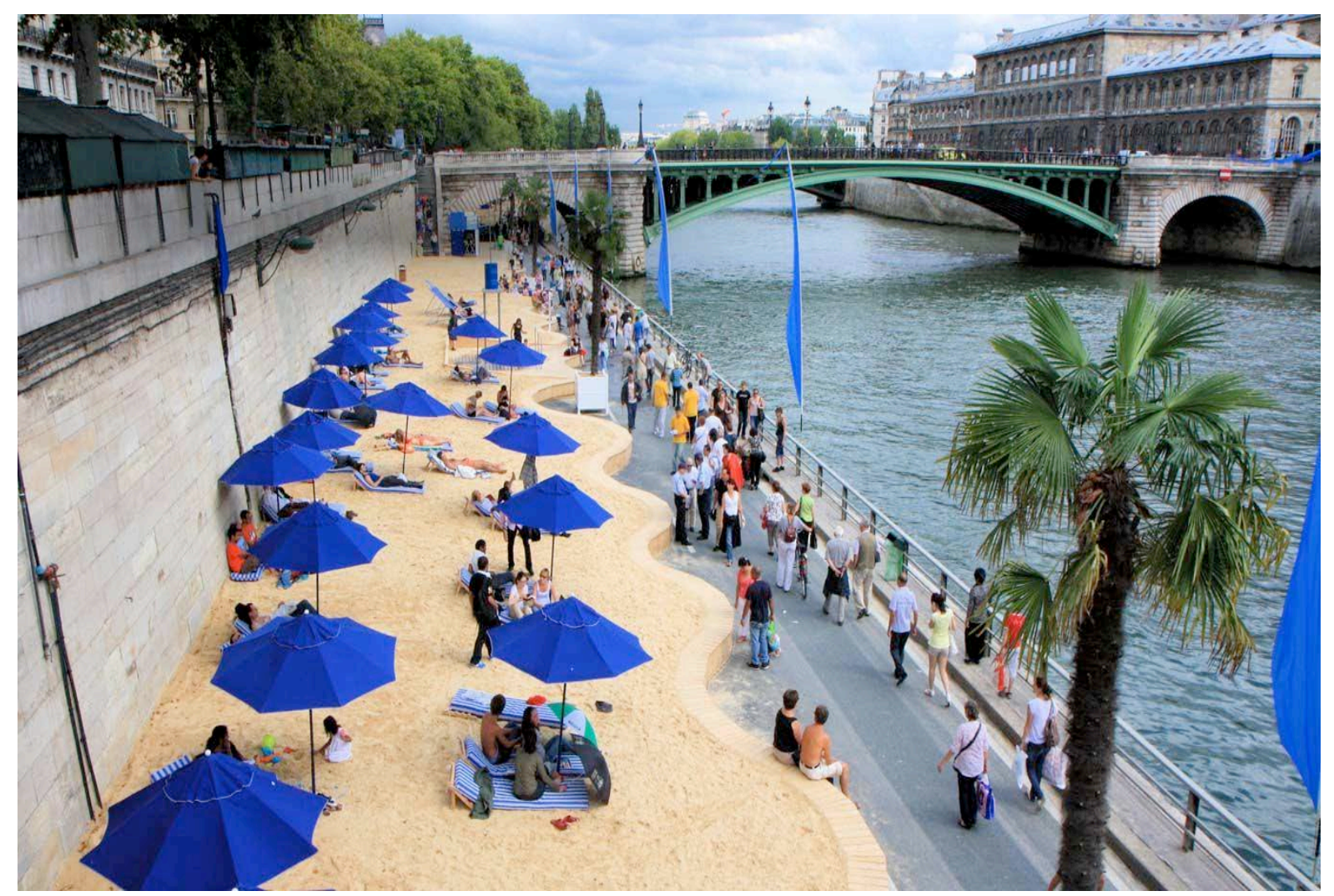

Jean-Christophe Choblet, Paris Plage (desde de 2002)

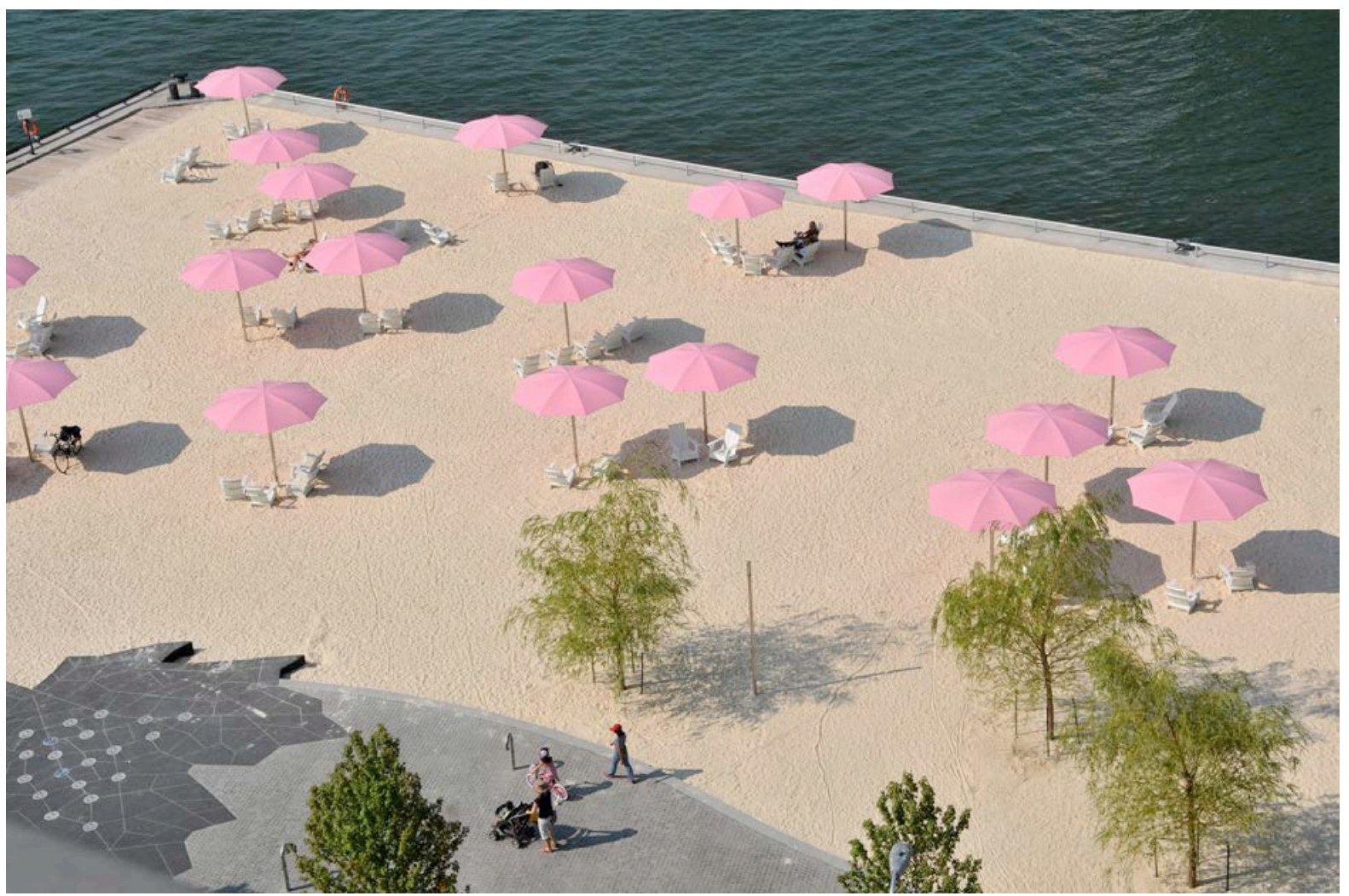

Claude Cormier, Sugar Beach, Toronto (2010) 
valorizamos apenas esses projetos isoladamente, mas, na tentativa de compreender o potencial que a praia traz às práticas contemporâneas, estendemos as suas significações ao contexto da discussão entre arte, arquitetura e urbanismo. A abordagem não se limita a esses campos, mas toca desde a fenomenologia até as dinâmicas sociais do espaço público. Os projetos agrupados aqui, representativos das condições observadas - alguns com papel protagonista na construção do conceito praiapaisagem e outros permanecendo como coadjuvantes na construção do conceito -, formam a matriz desta narrativa.

A praia se mostra como uma estrutura alternativa na apreensão de certas práticas e, como consequência, promove um olhar crítico como maneira de desencadear determinadas leituras sobre o universo urbano. Tais leituras, desenvolvidas a partir da produção de certos artistas e arquitetos, veem neste contexto uma particular fascinação, articulando assim uma síntese do imaginário da praia no âmbito do processo de criação, do desenho. A atenção à praia garantiria um outro olhar a tais práticas: arte e arquitetura permitindo uma nova percepção da cidade através da praia. O fenômeno da praia serve então como mecanismo para discorrer sobre certas questões entre arte e arquitetura. Mesmo que o mérito esteja localizado na confluência entre arte e a arquitetura e nos possíveis desdobramentos dos processos relacionados a este espaço-entre, a praia permite uma certa liberdade de entrada, pois o foco estaria suspenso, informado por uma outra característica fascinante: a ocorrência do real. $\mathrm{O}$ real a que me refiro seria o distanciamento lacaniano natural das coisas, forçando a verificação de certos significados através de uma outra entrada. ${ }^{5}$ Jacques Lacan discute o simbólico-realimaginário como um sistema interdependente de relações, originado pelo "palco do espelho", o primeiro momento em que tomamos consciência do eu. A praia entra nesta discussão como o "real", servindo aqui como um balanço entre as partes, criando um território mais livre de especulação, pois temos uma alusão mais tangível às especulações teóricas. São as expressões de uma gente que transformam o real em simbólico ou imaginário. O imaginário e o simbólico não habitam nas coisas em si, na realidade do mundo, e sim nas subjetividades de cada um. Por exemplo, a praia de Copacabana suscitou na criatividade carioca uma abundância de canções que agora fazem parte do imaginário do povo, como já mencionamos

\footnotetext{
${ }^{5}$ Ver Jacques Lacan, "Symbol and Language." In The Language of the Self. Baltimore: The Johns Hopkins University Press, 1956.
} 
em Caymmi, mas também em Tom Jobim, Alceu Valença, Fernanda Abreu, João de Barro, Billy Blanco e tantos outros. ${ }^{6}$

Tal motivação surgiu inicialmente fora do âmbito da produção cultural. Foi num momento desocupado em Copacabana que o desejo para tal projeto originou-se e consolidouse. Todos sabemos dos sérios problemas encontrados na zona metropolitana do Rio de Janeiro, dos espaços públicos conflitantes da cidade, mas mesmo assim Copacabana sobrevive como um espaço público digno e humano, profundamente influenciador da consciência do carioca. Adicionado a este fato, consideramos Copacabana um dos espaços públicos urbanos mais bem-sucedidos que conhecemos, por sua dimensão, completude, influência e cultura. $\mathrm{O}$ entendimento das dinâmicas que formam a complexidade deste recinto urbano específico desconstrói o mito da sua imagem. Então não nos atemos somente à sua imagem, mas como estratégia de abordagem empregamos um olhar mais específico sobre Copacabana, tentando deste modo assimilar as mais diversas camadas que constroem este lugar tão peculiar. Os fenômenos encontrados na paisagem empírica da praia urbana geram outras maneiras de pensarmos a cidade, agora como um espaço social em afinidade com a natureza humana e o ambiente urbano. Seria então plausível encontrar os mecanismos de procedimento de desenho para a proposição de arquiteturas e espaços públicos mais humanos, poéticos e sustentáveis a partir do modelo da praia?

A identificação inicial dessa potencialidade desenvolveu-se a partir de um mapeamento das práticas artísticas e arquiteturais onde a praia apresentava-se como referência direta enquanto localidade, tipologia, conceito ou estratégia. Projetos como a própria Copacabana de Roberto Burle Marx, as Piscinas de Leça de Palmeira de Álvaro Siza, ou mesmo Le Cabanon de Le Corbusier conversam com La Tumbona ou o Balneário La Perla, em Mar Del Plata, ambos de Clorindo Testa, ou com a Maritime Youth House de Julien De Smedt, em Copenhague. Marécaixão, Casco e Junco de Nuno Ramos, e Siestawatch de Fábio Marques seguem nos passos do namoro de Artur Barrio com o mar, ou com as fascinações urbanas de Hélio Oiticica. Ou mesmo os mais efêmeros e mitológicos In Search of the Miraculous de Bas Jan Ader, The Dig Cunt de Gelitin e B.C. México de Chris Burden, elegeram a praia como locus das suas imaginações. Foi a partir da identificação de expressões desta

\footnotetext{
${ }^{6}$ Antônio Agenor Barbosa, "Copacabana em música" (Vitruvius, Minha Cidade, 4 de outubro de 2003). Disponível em: <http://www.vitruvius.com.br/revistas/read/minhacidade/04.039/2035>. Acesso em 12 de novembro de 2012.
} 
natureza e definidas por uma afinidade profunda com a praia que o potencial da praia como modelo surgiu.

Mas consideramos a praia não só como o sítio destas experiências, mas também como citação, como referência a outras manifestações em espaços públicos desprovidos da totalidade que a praia apresenta, mas que assumem certas qualidades inerentes a ela. Esses espaços informais ou intuídos, intencionais ou construídos, articulados dentro de uma sensibilidade em relação ao solo urbano, oferecem a esperança dos espaços humanistas que regem a vida em comum, abraçando o respeito, a dignidade e a sociabilidade em uma espacialidade específica. Como não considerar a Piazza Del Campo de Siena, o Sheep Meadow do Central Park, ou a Place Georges Pompidou como alívios urbanos altamente utilizados e celebrados pelos seus habitantes? E o SESC Pompéia de Lina Bo Bardi ou o belvedere do MASP: não seriam esses verdadeiras praias urbanas? E a marquise do Ibirapuera ou o Minhocão num domingo de sol? Estes projetos que me refiro aqui como projetos-praia são, direta ou indiretamente, alusões à praia. Não à praia convencionada pela extensão de uma superfície de areia banhada pela água do mar, mas sim referências ao mitológico universo praiano, ao costume de ajuntamento humano numa superfície envolvente, sob uma intensa produção cultural contínua.

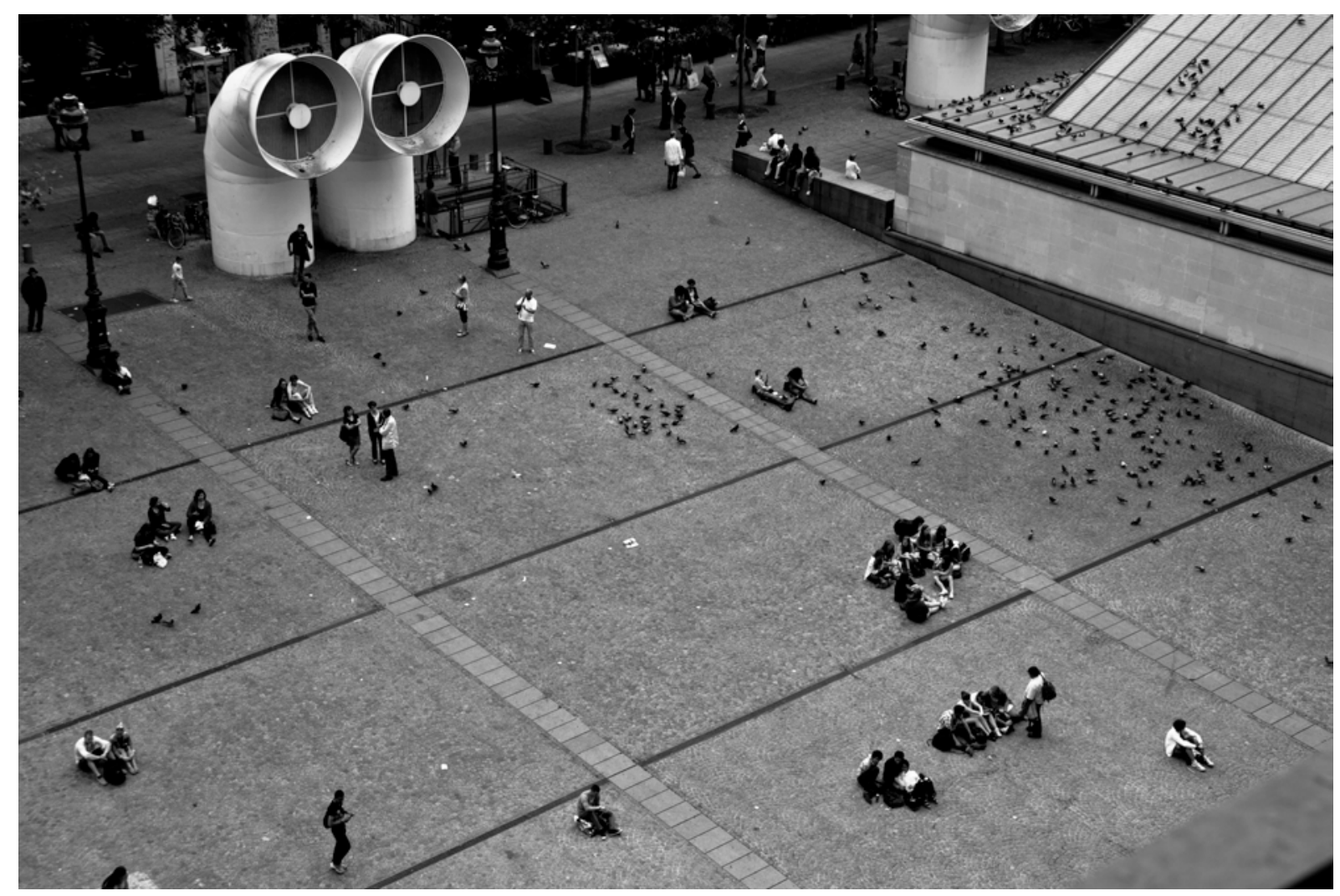

Place Georges Pompidou, Paris (1977) 
Acima de tudo, a praia urbana transforma o tédio das cidades em territórios eróticos, verdadeiros oásis do prazer. ${ }^{7}$ Tais projetos-praia, tanto arquiteturas como projetos de arte, traduzem o inato desejo de agrupamento social ou a simples necessidade de escape da multidão (ainda que estando no seu interior) indicando verdadeiras possibilidades para o espaço público urbano num estado erótico. Os espaços referidos como projetos-praia já demonstraram êxito com o comprovado teste do tempo. Escrutinamos aqui as especulações de tal êxito para assim traduzi-las em estratégias de desenho, dentro da operacionalidade do projeto.

Este território de prazer, fluido e experimental, marginal aos espaços de produção, opera em contraste com os respectivos comportamentos neoliberais. Os projetos mencionados acima, tanto os objetos de arte como as arquiteturas, estão, a rigor, fora dos contextos convencionais da galeria ou do museu (objeto de arte) ou do lote urbano (o edifício). Tanto o espaço da galeria quanto o lote urbano são instituições permanentes, partes do sistema de regulação da cidade e da cultura. Independente de um sistema ou outro, a praia aparenta ser uma válvula de escape para a imaginação e a experimentação, exatamente por se posicionar num lugar não ao todo definido, mas sim com uma qualidade de terrain vague com as suas potencialidades suspensas. A praia atua então como válvula para a congestão urbana, liberando variadas pressões da vida metropolitana para um espaço indeterminado e aberto de possibilidades.

A praia está para estes artistas experimentais (Barrio, Ramos e Marques) assim como o deserto estava para os artistas da Land art no final dos anos 1960. Projetos como Spiral Jetty de Robert Smithson, Roden Crater de James Turrell, ou City de Michael Heizer serviram de motivação para o deslocamento da experiência artística para fora dos limites da cultura urbana. Por analogia, saímos da cidade para a praia ou para o campo para nos livrarmos do congestionamento urbano. No caso dos artistas, o congestionamento era mais conceitual, psicológico ou político, relacionado ao confinamento cultural, então uma maneira de questionar o espaço da galeria como o lugar da obra, questões relativas à noção de confinamento cultural evidenciado nos escritos de Hélio Oiticica e Robert Smithson. ${ }^{8}$

\footnotetext{
${ }^{7}$ Paulo Mendes da Rocha sugere que a arquitetura tem que sempre perseguir a dimensão erótica da cidade (em conversas com o autor).

${ }^{8}$ Robert Smithson, “Cultural Confinement”. New York: Artforum, October 1972; e Hélio Oiticica, Aspiro ao grande labirinto. Rio de Janeiro: Rocco, 1986.
} 
$\mathrm{Na}$ trajetória destes questionamentos observamos que a análise convencional tanto da praia quanto dos projetos a ela relacionados limitam-se a especulações teóricas, o que nos impulsionou a examinar outras dimensões da praia. A praia, portanto, não pode ser tratada como objeto, nem como os projetos que trabalharemos aqui. Assim como a praia remota, bucólica, agregada à natureza, a praia urbana é mais do que um artifício autônomo e mostrase ao invés como uma rede de relações, como um componente integral à paisagem e às infraestruturas urbanas, dependendo de outras relações de lugar para existir. Esta interdependência com o lugar faz da praia mais do que um objeto e, sim, uma condição. Portanto o termo "praia" mostrava-se insuficiente e parcial, exigindo um novo termo para explicitar agora esta "condição-praia” não objetual. Então, o que poderíamos denominar "personalidades programáticas" ", as ações múltiplas que ativam o espaço da praia, chamamos agora de "condições", abrindo as possibilidades do argumento.

Redirecionamos assim a condição-praia para além de uma coleção linear e historicista de projetos e experiências, ficando evidente que o mais atraente é revelar esta condição-praia e as implicações teóricas que sugerem a praia como referência crítica à cultura urbana contemporânea. Para tanto, a coleção de projetos identificados ${ }^{10}$ é utilizada como uma genealogia crítica na articulação dos sistemas que pronunciam o fenômeno da praia além dos limites de simples paisagem ou objeto, mas agora como qualidade e fenômeno cultural. Ao invés de isolar cada projeto dentro das suas realidades específicas, vamos utilizá-los aqui na construção de uma matriz organizadora entre a praia e a cidade, entre as práticas instrumentais da arquitetura e do urbanismo e aquelas destinadas às conjunturas críticopoéticas. Se tanto a praia como os projetos-praia são tratados aqui como não-objetos, mas como condições, intencionamos claramente suspender a questão da praia em si, abri-la para uma nova leitura e experiência, e de nenhum modo exaurir as suas potencialidades. ${ }^{11}$

\footnotetext{
${ }^{9}$ Convenção tal mais frequentemente aplicada aos programas de arquitetura, os usos do edifício.

${ }^{10}$ No que se refere a este estudo nos concentraremos em cinco projetos-praia: Le Cabanon (Le Corbusier), Copacabana (Roberto Burle Marx), Éden/Tropicália (Hélio Oiticica), Marquise do Ibirapuera (Oscar Niemeyer) e Piscinas de Leça de Palmeira (Álvaro Siza).

${ }^{11}$ Para uma abordagem geral sobre a praia ver Lena Lencek e Gideon Bosker, The Beach: The History of Paradise on Earth. Viking, New York, 1998. Para uma abordagem específica sobre as praias do Rio de Janeiro ver Claudia Braga Gaspar, Orla carioca: história e cultura. São Paulo: Metalivros, 2004.
} 
II_A redescoberta da praia como espaço público

"Praiapaisagem"12 foi talvez primeiramente instigado por uma palestra, proferida em 2002, numa tarde quente em Havana, Cuba, no abafado salão do Convento de Santa Clara, a alguns passos da Plaza Vieja. Muitos sobreviviam pelas constantes abanadas de generosos leques. $\mathrm{Na}$ ocasião, o historiador Kenneth Frampton afirmou que o futuro da arquitetura residiria nas infraestruturas e na paisagem das cidades. ${ }^{13}$ Com um lúcido sentido de emergência Frampton deixou claro a necessidade premente de se recuperar a noção de relevância em práticas contemporâneas, com menos enfoque no edifício isolado (e glorificado) e nas políticas profissionais, e mais em uma arquitetura de relações que ambicione avançar as grandes questões urbanas e ambientais a serem enfrentados no século 21.

Com o olhar situado na experiência da praia, e considerando a transição do objeto da arte (a obra de arte) e do objeto da arquitetura (o edifício) dos seus estados autônomos para o ambiente urbano, tanto em práticas artísticas como em arquiteturas recentes, um momento significativo contribui na identificação contemporânea de tais práticas. Algumas atitudes específicas das vanguardas do século 20 relacionam-se ao conceito de praiapaisagem, indicando novas estratégias de ordenação da cidade contemporânea sugeridas por tais práticas. Para tanto o processo histórico nos levou a contextualizar a praia dentro da evolução dos processos artísticos. A praia assim é entendida não como uma tipologia isolada, mas como um sistema complexo, integrante da cidade, promotor e organizador da vida, expandindo e encolhendo simultaneamente aos experimentos humanos em constante movimento. ${ }^{14}$ A praia aqui é elemento central do questionamento da institucionalização da arte e a instrumentalização da arquitetura, estabelecendo-se como foco de uma tática espontânea e uma forma de investigação urbana alternativa apontando para uma estética de resistência.

Alguns procedimentos fundamentais desenvolvidos no século 20, especialmente

\footnotetext{
${ }^{12}$ Praiapaisagem é traduzida como Beachscape em inglês.

${ }^{13}$ Kenneth Frampton, "Globalization and its Discontents: Can eco-philosophy serve as a ground for contemporary environmental design?" Havana: Conferência Internacional da Association of Collegiate Schools of Architecture: Culture and the Challenges of Globalization, 2002. Nota-se o desenvolvimento da disciplina híbrida Landscape Urbanism (Paisagem-urbanismo) em universidades norte-americanas nos últimos vinte anos.

${ }^{14}$ Mesmo que a história da praia seja extremamente abrangente, como Alain Corbin nos mostrou de maneira fascinante em Le Territoire du vide: L'Occident et le désir du rivage, 1750-1840 [Paris: Flammarion, 1990], concentraremos os nossos esforços no estudo deste sistema complexo através da exploração sobre Copacabana.
} 
aqueles observados no processo de transição da prática artística do ateliê para a rua, nos ajudam a contextualizar o fenômeno da praia dentro da cultura teórica num momento de permanente transição. Então, as experiências de Charles Baudelaire ou Piet Mondrian, passando pelos situacionistas e pelas transformações dos anos 1960 (e.g. Vito Acconci, Allan Kaprow ou Valie Export), até chegarmos aos experimentos de Robert Smithson, e, no caso brasileiro, Hélio Oiticica, Ligia Clark, Artur Barrio e Nuno Ramos auxiliam na construção da presente narrativa. ${ }^{15}$ As manifestações mencionadas acima servem de referência direta à uma série de práticas contemporâneas investidas diretamente no locus da praia, e que são aqui categorizados em duas famílias: o primeiro grupo atua diretamente no âmbito da praia (sitespecific); o segundo, apreendendo-se das dinâmicas da praia, volta-se para a cidade, $\mathrm{e}$ utilizando-se do conceito de praiapaisagem como estratégia, busca a invenção de um novo espaço público (site-referential), sinalizando um ímpeto contemporâneo particular em relação à praia. Copacabana neste contexto surge como uma referência estrutural pois além de se posicionar de forma predominante na formação do imaginário brasileiro, também surge como suporte de experimentação da modernidade e das suas transformações através do século 20 adentrando no novo século.

Tanto a praia como os projetos-praia identificados aqui caracterizam-se por certas qualidades comuns: a expansão da superfície urbana, o fluxo constante, a definição de um campo em plena mutação, a ausência de objetos urbanos definidos, a multiplicidade de experiências e programas, e a noção de escape, de fuga. A praia assim nega uma situação fixa, de um objeto estático criado segundo às convenções do edifício, das infraestruturas ou do planejamento urbano. As suas condições estabelecem um novo conceito para o desenho urbano. Devido à sua categoria cultural o termo "praia” predispõe-se em comunicar adequadamente as complexidades desta condição em fluxo, pois sinaliza mais um objeto, uma pré-concepção, uma paisagem ou um destino. A utilização inicial do termo beachscape $e^{16}$ serviu de uma aproximação à esta nova condição, referenciando-se diretamente ao conceito de "scapes" de Arjun Appadurai.

\footnotetext{
${ }^{15}$ Todos estes artistas e outros desenvolveram projetos no contexto físico ou conceitual da praia.

${ }^{16}$ Eduardo Aquino e Karen Shanski. "Beachscape”. Complex Order: Intrusions in Public Space. Winnipeg: Plug In Editions, 2009, p. 42-47.
} 
III_ De beachscape à "praiapaisagem"

\begin{abstract}
Vejo localidade principalmente como relacional e contextual ao invés de escalar ou espacial. Vejo-a como uma qualidade fenomenológica complexa, constituída por uma série de conexões entre o senso de imediatismo social, as tecnologias de interatividade, e a relatividade dos contextos. ${ }^{17}$
\end{abstract}

O panorama cultural que produz um sentido único para a praia independente do contexto cultural onde ela se encontra, tanto quanto manifestação física quanto ideia, está presente em qualquer cultura do mundo. A praia convida e excita, a praia oferece preguiça e brinquedo, descanso e descompromisso independentemente de onde se localiza. A fascinação pela praia é mundial e inevitavelmente atracada aos movimentos da economia global. Esta economia não se resume aos fatores financeiros de trocas mas se expande pela troca cultural de ideias e desejos. A globalização da praia fica mais evidente via indústria do turismo. Não se frequenta mais e tão somente a praia local mas se viaja, se desloca enormes distâncias para se experimentar uma outra praia. Daí os "destinos turísticos", os resorts, os pacotes de viagem, etc. Dentro deste contexto a praia transforma-se em moeda corrente, assumindo um valor particular medido pela sua fascinação internacional.

Na tentativa de desvendar a lógica entre as trocas globais, sejam de informação ou ideias, o antropólogo indiano Arjun Appadurai utiliza o termo inglês scapes para designar uma condição mais adequada ao estado das transformações e complexidades do mundo contemporâneo, onde os processos encontram-se não mais estagnados, mas em constante fluxo entre as dinâmicas locais e as forças globais. ${ }^{18}$ Então, por exemplo, os processos midiáticos são tratados não como "mídia", um termo concluso e absoluto, mas sim como mediascapes, colocando em suspensão possíveis significados fechados. Appadurai propõe um esquema elementar para explorar essas disjunturas, especialmente em relação entre cinco dimensões de fluxos culturais globais que ele chama de: (a) etnopaisagens, (b) mediapaisagens, (c) tecnopaisagens (d) financiopaisagens e (e) ideopaisagens. Para Appadurai paisagem (scapes) como sufixo permite apontar a forma fluida, irregular destes horizontes.

Estes termos, utilizados com o sufixo paisagem em comum, indicam também que estas não são relações objetivamente estabelecidas, que aparentam ser exatamente o mesmo de

\footnotetext{
${ }^{17}$ Arjun Appadurai, Modernity at Large: Cultural Dimensions of Globalization (Public Worlds, Vol. 1). Minneapolis: University of Minnesota Press, 1996, p. 178, tradução nossa.

${ }^{18}$ Arjun Appadurai. Dimensões Culturais da Globalização. Lisboa: Teorema, 2005.
} 
todos os ângulos de abordagem, mas são "construções profundamente perspectivadas, inflectidas pela localização histórica, linguística e política de diferentes tipos de atores." ${ }^{19}$ Estes atores apresentam-se de formas variadas, incluindo estados-nações, empresas multinacionais, comunidades da diáspora, e grupos e movimentos sub-nacionais (sejam eles religiosos, políticos ou econômicos); também grupos íntimos e próximos, como aldeias, bairros, grupo de amigos e famílias.

Para Appadurai esta condição globalizante faz do indivíduo o último locus atuante deste conjunto perspectivado de paisagens, pois estas acabam por ser percorridas por agentes que vivem e constituem formações maiores, em parte à custa do seu próprio sentido que essas paisagens oferecem. A consequente noção deste processo é que este indivíduo, particularizado pelo próprio locus, se resguarda à sua própria imaginação como um ato de resistência às forças globalizantes, de uma certa forma sugerindo que o mundo globalizante faz o indivíduo ater-se no subjetivo local, o que ele chama de mundos imaginados.

A praia apresenta-se como um cenário ideal para a ação referida por Appadurai. A praia localiza-se entre ser paisagem e ser um mundo imaginado. Ao mesmo tempo mítica e provocante a praia urbana é uma paisagem que nos faz conceber um mundo constituído por imaginações historicamente situadas. A praia nos remete às subjetividades imaginárias no meio do coletivo objetivado. A paridade paisagem/mundo imaginado conceituado por Appadurai marca claramente a maneira de como Copacabana, por exemplo, impregna a vida do carioca. Se por um lado ela se apresenta como um espaço público acessível a qualquer momento, a praia em si como um território de ócio, ela também ocupa um lugar singular no imaginário local, nacional e global. A reinvenção do termo praia seria necessário então para a articulação dos conceitos apresentados aqui. Para tanto o sufixo scapes em português seria equivalente a agem (de paisagem ${ }^{20}$ ), então o termo aproximativo à complexidade dos desdobramentos desta discussão seria praiagem ou praiapaisagem. Estes pequenos ajustes da linguagem nos ajudam a estabelecer mais clareza nas direções da articulação do conceito. Abandonamos o termo original beachscape pois, mesmo fazendo mais sentido na linguagem de Appadurai, ficou evidente qual inapropriado seria utilizá-lo numa fala que está tão

\footnotetext{
${ }^{19}$ Idem, pp. 50-51.

${ }^{20}$ Etimologia: (1573) 'extensão de terra que a vista alcança' (Houaiss).
} 
próxima às questões da cultura brasileira e da nossa língua. Então a utilização do sufixo paisagem ${ }^{21}$ como complemento de praia consolida-se, portanto "praiapaisagem".

\section{IV_Antecedentes}

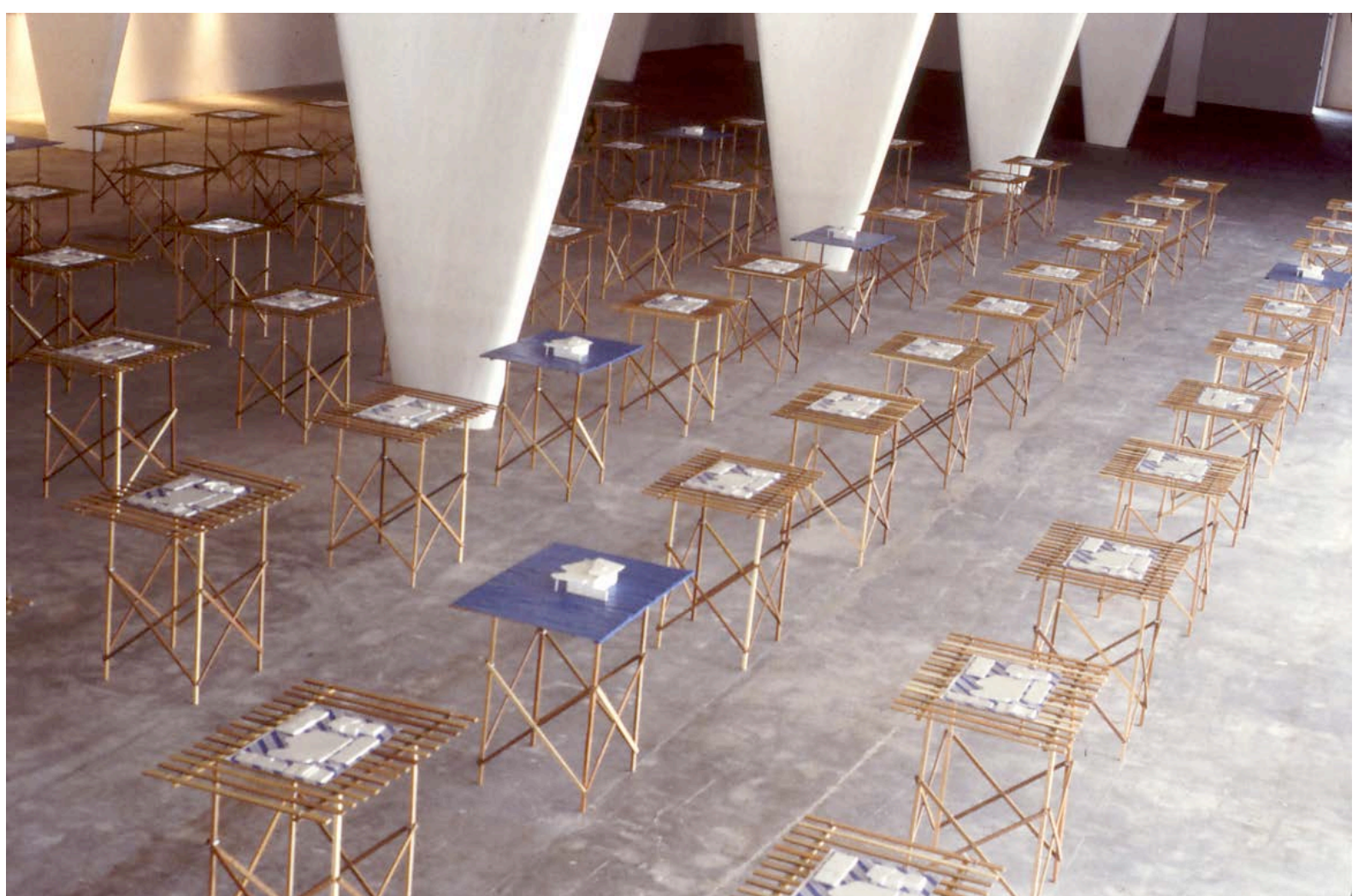

spmb, Projeto Camelô, Museu de Arte Moderna do Rio de Janeiro (2001)

A praia enquanto fenômeno só começou a fazer parte do meu processo formativo a partir das observações feitas durante a realização do Projeto Camelô ${ }^{22}$, no Museu de Arte Moderna do Rio de Janeiro em 2001, em colaboração com Karen Shanski. Mas é claro que desde criança frequento a praia. Originalmente através das férias de verão em Santos, Praia Grande e Itanhaém, depois na adolescência em Rio das Ostras e Ubatuba, e quando já adulto quando no Rio morei por três anos. Mas foi durante o Projeto Camelô que passei por uma transição entre o inconsciente e o consciente relativo à minha própria experiência pessoal com a praia. Na ocasião esta construção crítica do espaço da praia estabeleceu-se como elemento formador de uma outra consciência. Karen, vinda das pradarias canadenses, uma paisagem

\footnotetext{
${ }^{21}$ A tradutora Telma Costa da Editora Teorema traduziu o termo em inglês de Appadurai "scapes" para o sufixo "paisagens" em português. Adotamos aqui a sua tradução.

${ }^{22}$ Curadoria de Agnaldo Farias.
} 
interior desolada, despida de costas, densidades, topografias e fronteiras físicas, desenvolveu aguda percepção para os mais diversos aspectos e dinâmicas do espaço da praia de Copacabana, um espaço diametralmente oposto ao das pradarias. ${ }^{23}$ A praia, desde então, fazia parte somente do meu inconsciente imaginado.

Este distanciamento aguça as percepções sobre o "outro", como podemos notar em uma das abordagens sociológicas mais contundentes sobre as praias da zona sul carioca do acadêmico e geógrafo americano James Freeman. ${ }^{24}$ Confirmamos aqui a posição de Fredric Jameson $^{25}$, que considerou 'critical distance' como sendo um hábito típico do pensamento moderno, agora abolido no novo espaço pós-moderno. Para Jameson estamos submersos até o ponto onde nossos corpos são agora despojados de coordenadas espaciais, e praticamente (para não falar teoricamente) incapazes de distanciamento. Um distanciamento é necessário quanto da abordagem do objeto, e tanto Shanski nas suas observações intuitivas, quanto Freeman na sua crítica social ratificam a acepção de Jameson ao trazer o seu olhar estrangeiro à praia brasileira. Mais recentemente podemos também citar os trabalhos de Dawid Bartelt (Copacabana) e Julia O’Donnell (A invenção de Copacabana: Culturas urbanas e estilos de vida no Rio de Janeiro) como observações contemporâneas que atestam à esta nova consciência sobre a praia referenciando-se na significância de Copacabana.

Ao invés da concentração no simples objeto este universo onírico sugere novas relações da praia com outros processos da cultura contemporânea. Reentramos na cidade a partir da praia tendo nas práticas artísticas um mecanismo para se repensar os procedimentos de desenho, elegendo as intercepções entre as disciplinas para navegar com mais determinação através do desta complexa condição. A investigação da praia vem de encontro a algumas questões que se confundem com a recente historiografia da nossa arte e arquitetura dos últimos quatro decênios, definida pela rejeição do arquétipo simbólico gerado pelo ideário pós-moderno, e a persuasão do ideal regional moderno, impactado pela influência de Brasília, Niemeyer e Artigas. Uma contradição em relação à produção da arquitetura brasileira observou-se pela insistência de um quadro estigmatizado pela grande persuasão da tradição moderna brasileira às novas gerações. Do outro lado tínhamos uma produção artística de

\footnotetext{
${ }^{23}$ Por contradição as pradarias se localizam num fundo de um antigo mar, o glacial Lago Agassiz.

24 James Freeman. Great, good, and divided: the politics of public space in Rio de Janeiro. Journal of Urban Affairs, v. 30, n. 5, pp. 529-556. Hoboken, NJ: Wiley, 2008.

${ }^{25}$ Fredric Jameson. Postmodernism, or, The Cultural Logic of Late Capitalism, London: Verso, 1991.
} 
cunho experimental que alcançou enorme autonomia através da influência de artistas da geração do neoconcretismo, especialmente Lygia Clark e Hélio Oiticica, que, acima dos mandatos coletivos de um momento estético, nunca abandonaram seus próprios projetos pessoais, afastando-se de quaisquer dogmas, desenvolvendo assim um compromisso com a invenção pura.

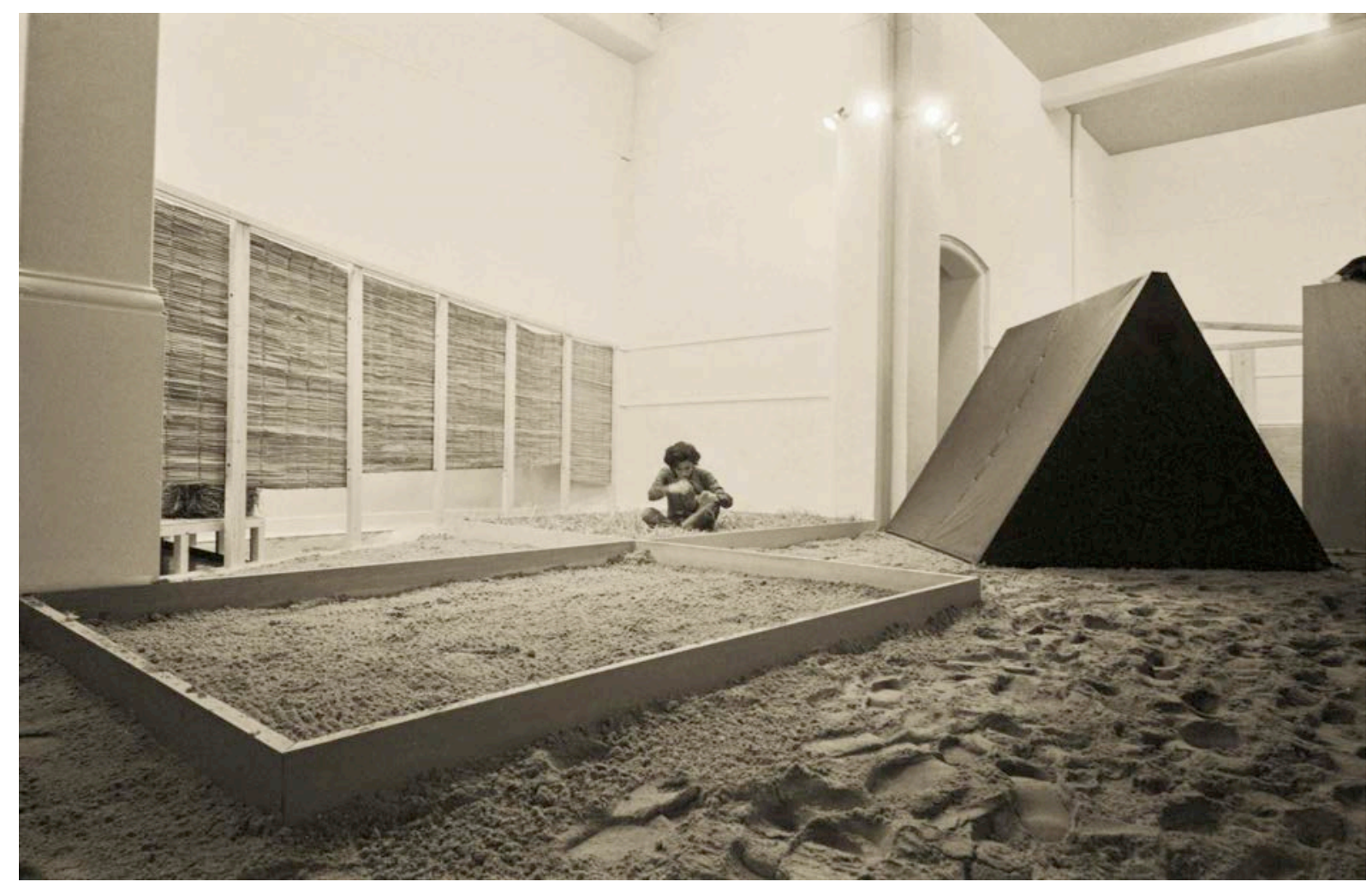

Hélio Oiticica, Éden, instalação incluindo PN5 Tenda Gil e Caetano, Whitechapel Art Gallery, Londres (1969)

O deslocamento do olhar sobre o objeto e o enviesamento para a praia constitui uma estratégia paralela de problematizar a leitura crítica dos procedimentos do fazer arte e arquitetura. Para evitarmos aqui armadilhas formais abordamos pelo viés político e filosófico deste argumento, identificando uma nova evidência nas questões que vão de encontro aos grandes problemas enfrentados pelas nossas cidades e seus espaços urbanos. ${ }^{26}$ Estas questões, colocadas nos interstícios entre arte e arquitetura, tombam instantaneamente no problema do espaço, do espaço topológico e conceitual, do espaço tridimensional, do espaço físico, do espaço público, dos espaços das nossas cidades. O espaço da cidade é então considerado uma

\footnotetext{
${ }^{26}$ Rem Koolhaas afirma que "a cidade é tudo o que temos". Ver Rem Koolhaas, “What Ever Happened to Urbanism?" In OMA (with Bruce Mau), S,M,L,XL. New York: The Monicelli Press, 1995, pp. 959-971.
} 
somatória de todas as complexidades espaciais, pois, simultaneamente o espaço não pode ser isolado por categorias autônomas, mas sim compreendido como uma entidade em contínuo permanente, onde as suas fisicalidades conversam incessantemente com todas as suas consequentes dinâmicas. A cidade com seus tecidos urbanos inchados, infraestruturas falíveis, problemas crônicos que a inadequação de uma arquitetura ensimesmada, fechada em seu próprio isolamento e obcecada pela aura do edifício, não encontra direções para responder à situação urbana contemporânea. ${ }^{27} \mathrm{O}$ redirecionamento do projeto intercepta procedimentos urbanísticos com as possibilidades da praia levando assim a um novo esclarecimento da vocação do desenho dentro de uma visão urbana renovadora.

Neste sentido as manifestações em arte e arquitetura, se colocadas em diálogo direto, demonstram atitudes e viabilidades de praiapaisagem como conceito e estratégia. Estes projetos, não mais assumidos como objetos finais de análise, mas inter-relacionados às teorias, organizam as informações, a reflexão crítica, e as análises necessárias para articular e construir praiapaisagem, focados aqui em três encaminhamentos: [1] A identificação do fenômeno da praia em seus vários desdobramentos e a apreensão da sua complexa estrutura formativa; [2] A abordagem crítica das condições espaciais fundamentais encontradas na praia; [3] A revelação de táticas de ação para um novo desenho do objeto e do desenho urbano, visando a constituição de espaços públicos, pautando-se por projetos específicos.

Duas vertentes se valeram como motivação central, formando uma dialética em relação a este tema: num mesmo momento em que um distanciamento geográfico e cultural permitiu as aberturas à sua percepção, ${ }^{28}$ uma necessidade premente de desviar os olhos do objeto surgiu para evitar um esvaziamento imediato com as proximidades que a questão apresentava — de tão próximos não conseguimos ver — fato este devido ao "inconsciente da praia" na experiência brasileira.

A praia é uma síntese, uma epítome do universo cultural brasileiro, qualificando-se como um espaço público triunfal, que alivia frequentemente a congestão urbana através de um indeterminado equilíbrio ambiental e social, injetando um enorme espírito positivo na psique brasileira. Tais fatores não se reservam às características ambientais dos sistemas ecológicos da praia, da faixa tropical, do acúmulo exorbitante do número delas no nosso

\footnotetext{
${ }^{27}$ Ver Pier Vitorio Aureli, “Toward the Archipelago: Defining the Political and the Formal in Architecture." New York: Log Journal 11, 2008, pp. 91-119.

${ }^{28} \mathrm{O}$ meu deslocamento Brasil-Canadá desde de 1987, e retornos repetitivos e constantes.
} 
litoral, mas principalmente nas maneiras que este tipo de lugar se assentou no espírito e na rotina das pessoas. A praia apresenta-se como infraestrutura urbana essencial em alguns casos (e.g., o bairro de Copacabana), articulando a transição das relações entre o homem e a natureza, e entre os homens com eles mesmos por apresentar-se como suporte para as relações sociais. Poderíamos então qualificar a praia como um modelo a informar estratégias de projeto para outros espaços públicos, influenciando a maneira de como desenhamos as nossas cidades?

A praia transforma-se em um estratagema para refletir sobre o território urbano, o local do encontro humano, o lugar em que habitamos a cidade, desvendando um outro desenho, a partir de um gesto aparentemente invisível que se dá intensa e cotidianamente na praia urbana. Nesta viva complexidade vemos uma esperança humanística para a continuidade da construção dos espaços em que habitamos em harmonia aos grandes balanços ecológicos futuros. Ecologia aqui no sentido mais amplo de oikos: casa, lar e família. Oikos não cria uma separação entre homem e natureza no sentido da administração dos recursos naturais e da proteção à natureza, mas considera o binário homem-natureza como uma totalidade. Tanto a praia quanto os espaços públicos das cidades tem que ser tratados como as nossas próprias casas, como que tivéssemos o mesmo senhorio sobre os nossos espaços públicos que temos em relação às nossas casas, às nossas famílias. Casa aqui não é tratada no senso piegas de "lar", mas no seu sentido maior, da construção do lugar. Numa primeira instância desconstruímos a praia enquanto objeto ao tratá-la como um campo. A praia então revela um laboratório de possibilidades para outros tipos de ocupação e experiência na cidade: o espaço público e a casa.

A praia aqui não é mais vista como a faixa litorânea de areia. Consideramos que esta superfície é algo difícil de mesurar ou de analisar segundo as convenções urbanísticas tradicionais. Tais procedimentos não fariam jus à sua própria complexidade. A praia não se limita à uma condição visível e palpável, sujeita à quantificações, e portanto representável, mas sim evolve como um fenômeno múltiplo onde o físico, espacial, ambiental, cultural e social vivem integrados dentro de uma continuidade indeterminada e temporal. Tal como a análise crítica de um edifício não se vincula simplesmente ao seu caráter construtivo mas passa também por constitutivos históricos e da própria experiência fenomenológica do habitar, a praia em si demanda uma outra abordagem crítica. Os projetos agrupados aqui, representativos das condições discutidas, alguns com papel protagonista na construção do 
conceito praiapaisagem, e outros permanecendo como coadjuvantes na construção do conceito formam a matriz desta narrativa.

Historicamente, as práticas de vanguarda iniciadas no século 19, que tanto informou a transformação da prática moderna, lançou um empenho ético e político na realização de escolhas absolutamente livres e impreteríveis, produzindo um novo "público”. Surge a partir dos movimentos dos anos 1960 um ator participante nos processos e rapidamente informando as práticas artísticas da época: o participante. Um novo questionamento do espaço da galeria é formado como uma oportunidade de fugir do confinamento cultural, agora ativando e ocupando a rua como sítio e suporte do trabalho, gerando uma outra experiência estética, definida pelo aparelho de operações ditados pela indeterminação do espaço urbano. Imediatamente a questão do lugar da arte é tratada em relação às transformações sociais e políticas da esfera pública, desafiando igualmente a questão formal do objeto. O artista está de volta à rua. No caso do Brasil, no inicio do século 20, a partir da metropolizacão dos centros urbanos em crescimento, as referências iniciais à praia surgem. Primeiro pela ocupação ociosa da praia nos anos 1920, como no caso de Copacabana, onde se descobre que podemos finalmente "ir à praia". A performance original foi na verdade da atriz francesa Sarah Bernhardt quando foi ao Rio 1886 para se apresentar no Teatro São Pedro. Na sua estadia na cidade chocou os moradores ao tomar banho na praia de Copacabana. Mas foi bem mais tarde, nos idos dos anos 1920, que a visita à praia bem como o banho de mar tornaram-se comportamentos aceitáveis até serem reconhecidos por decreto municipal.

Através das táticas situacionistas os anos 1960 representaram uma reinterpretação da imagem da praia com fins políticos. Confundidas pela a ocupação do solo urbano através do movimento estudantil - sob o asfalto, a praia! - o processo situacionista assume o inverso, pois não mais sonhando com o ideal idílico que a praia oferecia, poderia assim transformar este ideal na realidade do solo urbano onde as lutas libertárias estavam localizadas. A superfície urbana então era transformada num território habitado por implicações críticas para uma nova noção de público e democracia. Tais referências à praia podem ser localizadas nas barricadas estudantis onde o paralelepípedo das ruas parisienses eram removidos pois a sua fixação, dependendo somente da areia, provavam uma flexibilidade enorme de movimentação dos blocos, ao mesmo tempo que revelava na sua superfície ulterior a imagem da praia, do sonho da praia revelado pela presença da areia solta no meio da cidade - a praia vira um ideal de liberdade e democracia. 
Simultaneamente às ações de cunho situacionista em Paris e através do mundo, no âmbito das práticas artísticas os trabalhos de Robert Smithson, Artur Barrio e Hélio Oiticica da época sinalavam uma condição para além das convenções dos circuitos tradicionais da obra. Se por um lado as primeiras referências em Smithson aparecem na praia bucólica e distante (Mirror Displacement, praia Chilsea, Portland Island, Inglaterra, de 1969 ou Fourth mirror displacement, praia do Golfo do México de 1968), e em proximidade com a ideia de deserto [Land Art], a sensibilidade com a praia para Barrio (Uma Observacão........6 Aproximacões.........1 Recuo......., de 1975, ou Serpente de 1983), ou Oiticica (um dos seus Bólides tem água da Praia de Ipanema e o asfalto da Avenida Presidente Vargas) apresenta-se mais urbana e serve como um curto-circuito das relações entre o território público e a arte, expandindo a superfície urbana do interior dos seus limites simbólicos, e ampliando a operacionalidade do objeto de arte, agora não mais confinado ao espaço da galeria. Na esfera da contemporaneidade esta superfície expandida e indeterminada vira o locus da prática de forma frequente e familiar, resultado de um longo processo histórico.

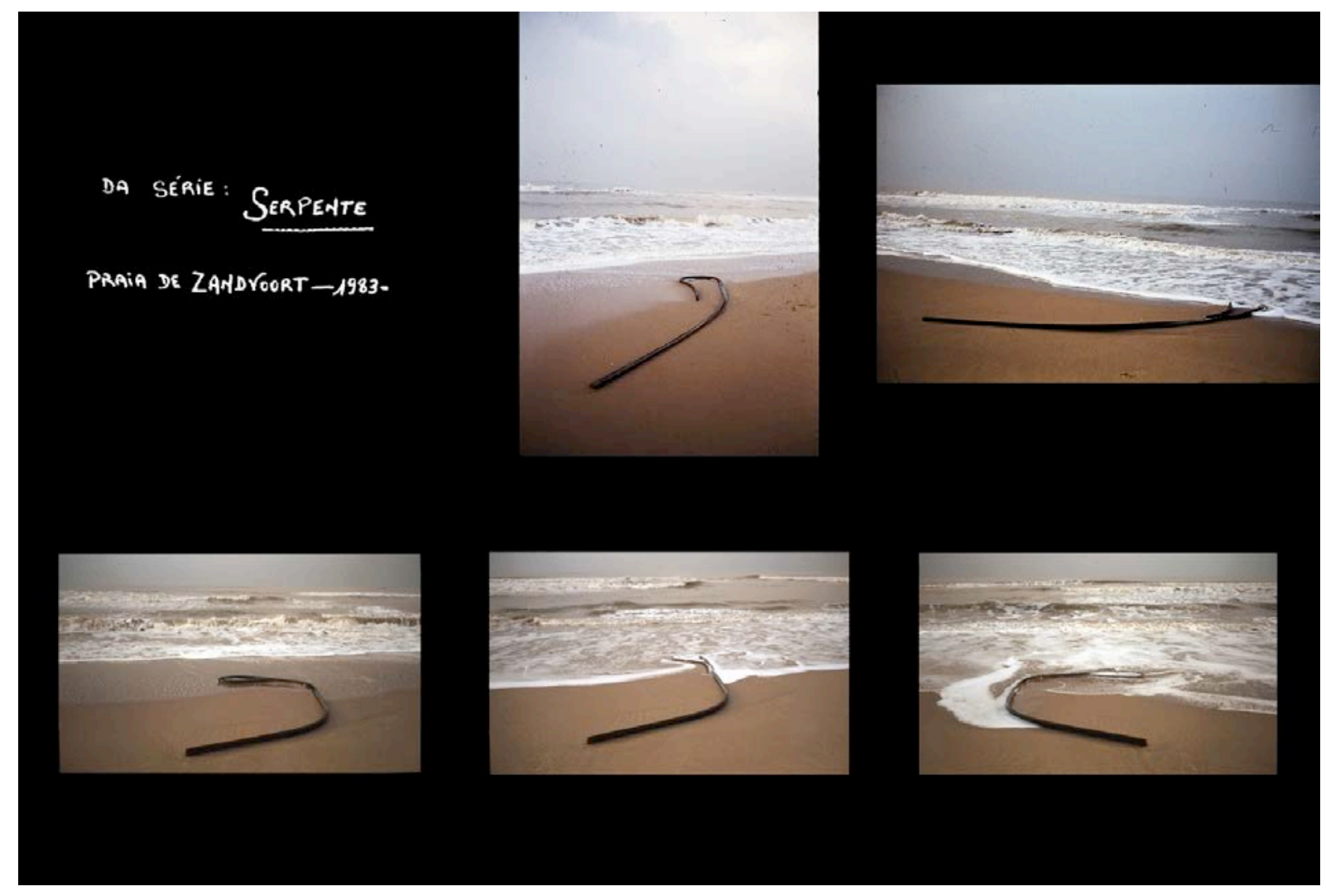

Artur Barrio, Serpente, Praia de Zandvoort (1983) 
Nesta mesma época existe o amadurecimento no Brasil do Neoconcretismo, e na América do Norte do minimalismo. Neste processo a passagem da escultura rumo à instalação e outras manifestações no espaço crítico da tridimensionalidade começam mesclar algumas teses fundamentais da escultura em relação com a arquitetura. Nesta progressão contínua da tela ao objeto $>$ da escultura à instalação $>$ do ateliê à rua $>$ da instalação à arquitetura $>$ da performance ao espaço público - fica instaurada a nova complexidade do objeto que agora desvencilha-se da lógica estruturalista para explodir-se e desdobrar-se abrindo um novo modo de operação transversal. Estes processos não se dão mais segundo uma coerência linear, mas sim colapsam-se em momentos díspares e invertidos. Assim como a arquitetura se transforma em representação ${ }^{29}$ e a escultura em forma habitada, o espaço público detêm um novo papel na construção de uma outra genealogia do espaço, agora sob as implicações das complexidades de um território público-social, tornando-se uma expressão artística independente, um novo gênero. ${ }^{30}$

Tais práticas se relacionam às questões centrais na construção de praiapaisagem. Nas aproximações entre os trabalhos de Gabriel Orozco e Richard Serra, por exemplo, observamos um diálogo aparentemente improvável que tenta localizar alguns pontos de tangência em relação à situação da produção tridimensional contemporânea. Um dos vínculos propostos entre as duas obras seria a passagem da verticalidade à horizontalidade dentro dos seus procedimentos artísticos formais, contextualizados aqui com outras manifestações em escultura a partir dos anos 1960, e apresentados como uma maneira de compreender as aberturas radicais das definições e limites contemporâneos que os dois artistas propõem. Uma outra tangente seria o contraste enquanto às suas escolhas materiais, e como tais escolhas (efêmero no caso de Orozco / permanente no caso de Serra, leve no caso de Orozco / pesado no caso de Serra) produziram consequências distintas relacionadas ao tratamento da gravidade e do tempo. Neste processo de articulação de praiapaisagem as transformações do objeto pelos procedimentos experimentais em escultura são primordiais na construção de uma epistemologia própria, pois tanto conceitualmente ou fenomenologicamente, constituem

\footnotetext{
${ }^{29}$ Por exemplo, o movimento Paper Architecture na Rússia, ou as teorias e experimentos dos Five Architects nos Estados Unidos no anos 1980 apontam para a ressurreição da arquitetura como forma pura de arte.

${ }^{30}$ Ver Susan Lacy, Mapping the Terrain: New Genre Public Art. Seattle: Bay Press, 1994. New Genre Public Art: grafite, arte pública, paisagens experimentais, performance, instalações efêmeras são só algumas manifestações que consideram nos seus fundamentos o "público" como material.
} 
uma estrutura de abordagem com mais afinidade ao estudo da praia do que as convenções quantitativas do urbanismo instrumental, haja visto a sua condição de efemeridade.

A partir da construção desta improvável aproximação entre a praia e as práticas artísticas temos um território híbrido que revela temas como a monumentalidade (Henri Lefebvre), arte como serviço (Walter Grasskamp), ou mesmo simbolismo e arquitetura (Dan Graham). Se para Lefebvre os monumentos em espaço público significam a consolidação de um símbolo opressivo, podemos então considerar a praia como um anti-monumento, pois na sua grandeza simbólica convida o cidadão para o seu interior ao invés de expulsá-lo, oprimilo. A questão da arte como serviço, abordada por Grasskamp, nos remete à transformação do monumento através do aparecimento da arte pública como prática. É nesta nova zona de ação aonde o trabalho de Dan Graham desenvolve-se. O objeto escultural vira arquitetura sintetizando a relação entre o simbólico e o fenomenológico: nos seus pavilhões o símbolo central não é mais o objeto da arquitetura em si mas sim aquele que a experimenta.

Se voltamos aos estreitamentos e lacunas entre os trabalhos de Richard Serra e Gabriel Orozco observamos uma aparente disparidade, apontando para a um componente comum: o ressurgimento da superfície como elemento constitutivo do vocabulário escultórico. Aqui propomos a ideia de que uma superfície vertical converge-se à visão, e uma superfície horizontal tende ao convite à participação, à relação direta com o corpo (como no caso de Carl Andre, Bert Theis, Gabriel Orozco, Félix González-Torres ou Andrea Zittel). A genealogia da superfície pela história da escultura do século 20, sintetizando a passagem do vertical ao horizontal, marcam um renovado interesse pela superfície tanto em relação à obra de arte, quanto à evolução da superfície urbana e tecnológica.

A transposição da superfície da escultura para a superfície urbana constrói uma nova dialética entre o objeto, o lugar e o corpo, demandando uma nova expansão das significações da cidade em relação à arte: a cidade vira o material e o lugar da ação. Fenomenologicamente a escultura se aproxima da cidade como uma síntese, como um modelo estruturador de relações paralelas. O objeto (de arte / o edifício) por sua vez perde a aura da autonomia nostálgica e passa a assumir o papel de negociador destas relações, não mais ocupando a função tradicional como fazia a escultura - elemento embelezador, estetizante do espaço público. Em urbanismo um processo similar desenvolve-se pela atenção recuperada aos objetos urbanos (edifícios), investindo-se mais nas dinâmicas entre eles, assinalando uma outra ordem transferida à superfície urbana. Este desvio ocorre devido à percepção de que 
edifícios na cidade não significavam apenas representações mas que de fato carregam o potencial da produção dinâmica dos espaços urbanos, organizando também as experiências que se passam através deles.

Daí a renovação da disciplina "arte pública" que veio, a partir dos conflitos encontrados com as experimentações desenvolvidas a partir dos anos 1950, e culminadas por Richard Serra com o Tilted Arc (1981), transformar a idéia do objeto autônomo. A controvérsia final sobre o Tilted Arc pode ser resumida pelos direitos ao espaço público e pelos paradoxos entre o vertical e o horizontal. A imponente verticalidade da escultura, muito mal compreendida na época pela sua inusitada implantação (atravessando o caminho de pedestres) competiu com a horizontalidade da Federal Plaza, pois esta superfície já possuía no seu desempenho original a capacidade de receber a ação dos pedestres de maneira espontânea. Então, quando da instalação de Tilted Arc, ficou claro na percepção daqueles que haviam clamado o espaço público que um direito tinha sido removido pela obra de arte. A escultura em seus termos clássicos encontra uma reação, pois vista no contexto do espaço público é reinventada agora pelas novas lógicas urbanas, residindo entre a valorização do capital neoliberal e as resistências localizadas.

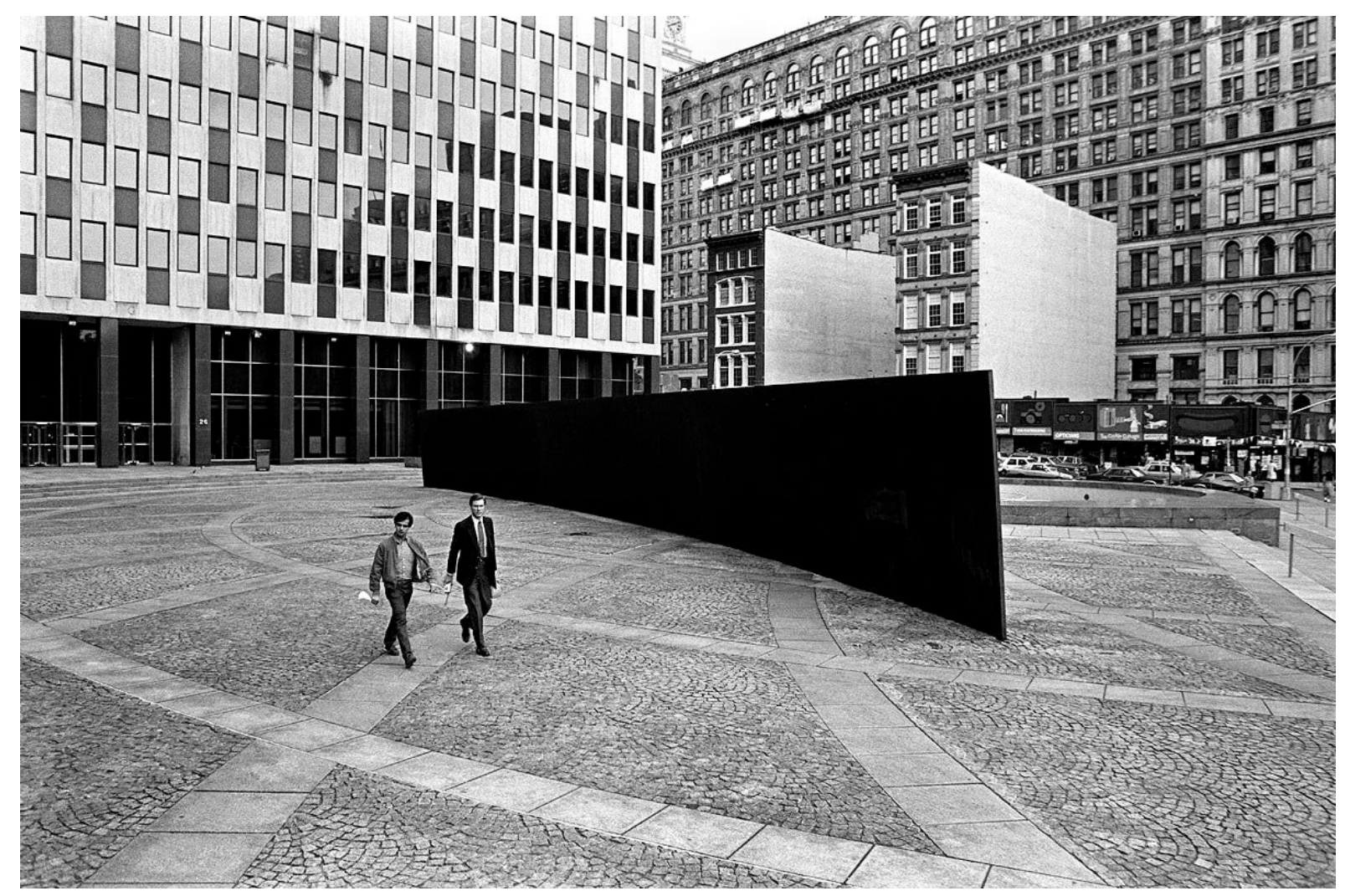

Richard Serra, Tilted Arc, Federal Plaza, New York (1981) 
A partir destas novas dinâmicas a relação entre o corpo, a obra e a cidade, e noções como o site specific, aproximam arte e arquitetura como constatado na sua gênese no trabalho dos minimalistas Dan Flavin, Donald Judd, Sol Lewitt, na produção pós-minimalista de Dan Graham, Bruce Nauman ou Michael Heizer, ou no devaneio de Hélio Oiticica no contexto urbano-cultural brasileiro. Por outro lado, a especulação sobre a paisagem, arquitetura e cidade começa a ser discutida com o surgimento da disciplina Landscape Urbanism (Paisagem Urbanismo) em meados dos anos 1990. Como estas relações encontram-se no espaço público, surge a necessidade de complementar a tríade arte / arquitetura / cidade respondendo ao enquadramento proposto por Landscape Urbanism.

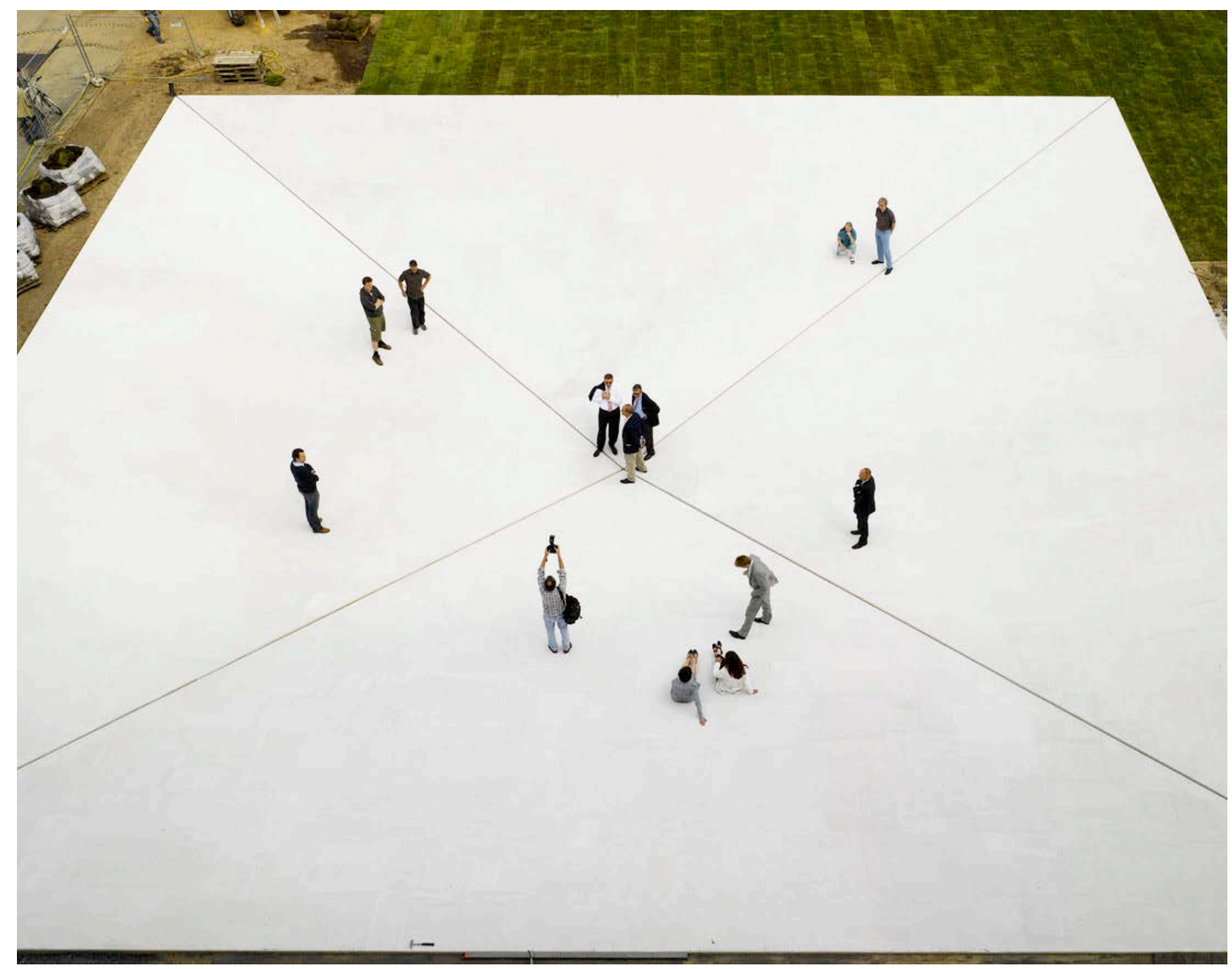

Bruce Nauman, Depressed Square, Münster (1977-2007)

Henri Lefebvre afirmou que "no futuro a arte não será artística e sim urbana" ${ }^{31} \mathrm{O}$ legado teórico do pensamento urbanístico das últimas décadas do século 19 até as primeiras

\footnotetext{
${ }^{31}$ Henri Lefebvre, Writings on Cities. Malden: Blackwell Publishers, 2000, p. 173, tradução nossa.
} 
do século 20, incluindo a emergência e a crise da cidade funcionalista, os paradigmas do urbanismo americano, até ao urbanismo contemporâneo apontam situações conflitantes entre plano e projeto, exigindo uma referência mais precisa e generosa tanto em relação à evolução das formas urbanas, como da compreensão da praia numa leitura no contexto urbanístico. As pautas do urbanismo contemporâneo incluindo as suas escalas, o crescimento urbano, a nova dimensão das aglomerações urbanas, a mobilidade e a expansão urbana oferecem uma oportunidade de observarmos a praia como superfície e infraestrutura urbana. O projeto de Lille de Rem Koolhaas/OMA, por exemplo, indica a reinvenção urbana da cidade através da articulação de uma peça infraestrutural urbana que adiciona qualidades de conectividade entre o antigo centro histórico e o novo bairro e o centro de serviços. Esta peça urbana desdobra-se igualmente em uma superfície estendida onde provem serviços como circulação e estacionamento no seu interior, multiplicando-se na dinâmica da cidade e tratando a sua parte superior como um novo parque urbano, uma praiapaisagem.

Praiapaisagem, contrariamente, indica um retorno à experiência da metrópole do século 19 e Charles Baudelaire, não só pela experiência do flâneur através da figura da desocupação e do ócio, mas também representada pela experiência de Walter Benjamin através da sua estratégia de montagem. Sendo assim, o espaço urbano assume o papel da obra e a superfície urbana a forma estruturadora do seu contexto. Não mais como objeto urbano isolado e secundário, a praia vira protagonista geradora de sistemas complexos produzindo uma nova taxonomia do espaço. Como a arquitetura é aparentemente ausente pois não existem "edifícios" em si na praia, o objeto de arte não mais pode ser considerado segundo as antigas regras, confinados na sua própria objetividade, dentro da autonomia escultórica. A aura tridimensional, tão dogmatizada pelo projeto moderno, se dissolve em múltiplas dimensões constituindo agora a nova razão do objeto. Estas novas dimensões, vistas através da experiência da praia, servem como plataforma comum entre arte, arquitetura e cidade. Em contrapartida, alguns aspectos da informalidade dos espaços urbanos públicos da praia apontam para certos padrões de ocupação que se relacionam com a maneira de conceber o espaço a partir da cultura informal, considerando a superfície da praia como um sistema urbano macio, transformando a superfície urbana num "campo indeterminado", num "urbanismo interior". A partir desta constatação as infraestruturas urbanas e as suas relações com os tecidos urbanos adjacentes tornam-se essenciais na compreensão da praia como fator 
central na constituição das cidades praieiras. A praia agora é vista "em relação" aos outros objetos urbanos e não apenas como destino pitoresco final.

O fenômeno da praia no contexto das questões vigentes na interseção arte e arquitetura expandem o enquadramento das narrativas dominantes, pois estas relações, dadas as complexidades observadas, navegam simultaneamente entre arte, arquitetura e o espaço público, estabelecendo um campo de argumentação onde a condição contemporânea da cidade são regidas pelas produções culturais influenciadoras das manifestações urbanas. Podemos aqui dizer que nem as especulações teóricas, nem as observações de campo seriam o suficiente para localizarmos o fenômeno da praia de forma sistemática. Então a discussão limita-se necessariamente a duas direções: na abordagem epistemológica da condição predominante da superfície a partir da experiência da escultura como sendo a condição topológica análoga à praia, atendo-se principalmente aos paralelos verificados nos processos artísticos bi e tridimensionais (do objeto para a superfície); e na segunda direção concentra-se na transição dos fenômenos localizados no discurso crítico-teórico do objeto (de arte) para o espaço público (da superfície para a relação), incorporando a cidade e seus atores como elementos íntegros da praia.

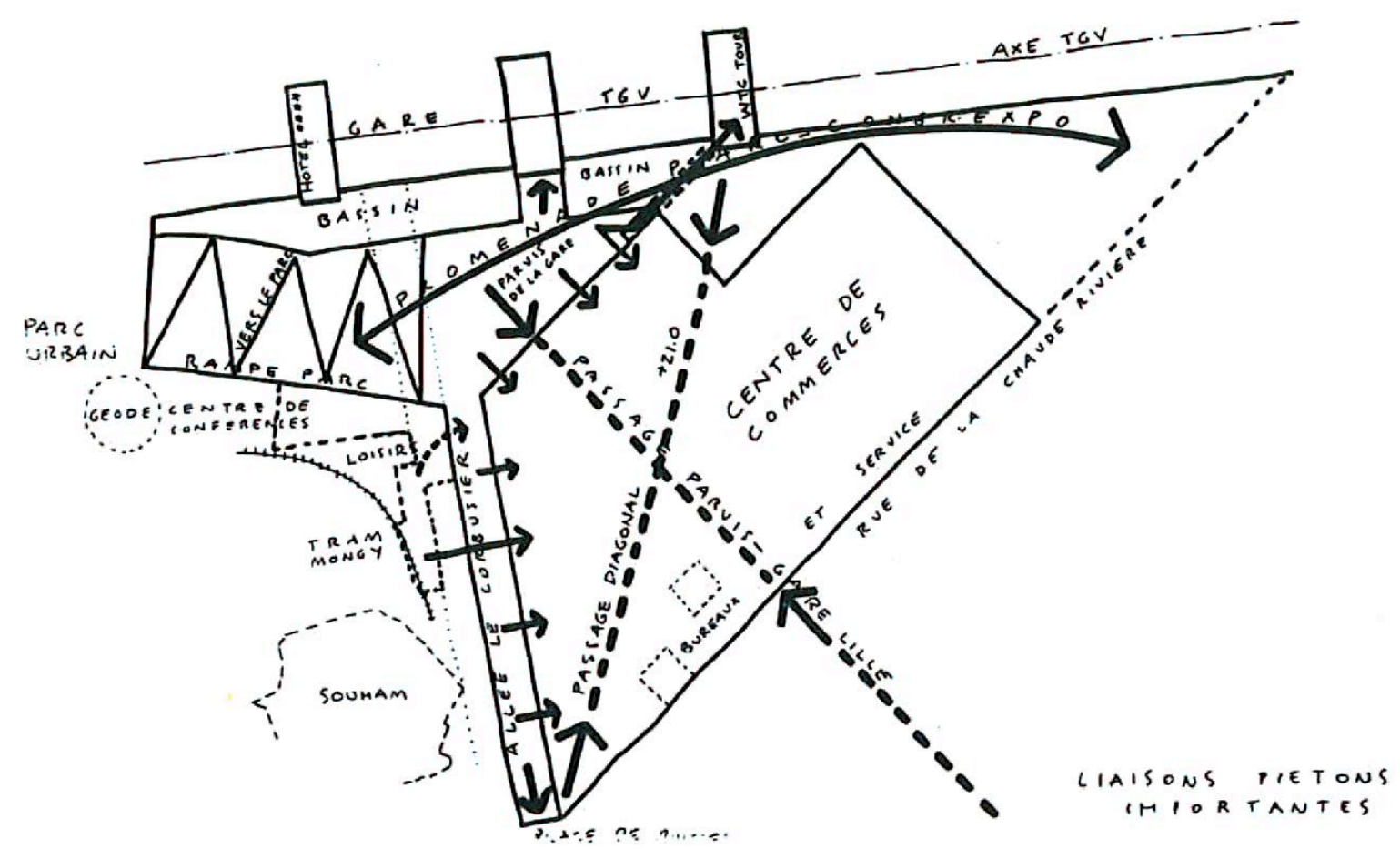




\title{
3_ TRÊS DESENHOS: A QUEBRA DOS LIMITES DO ESPAÇO NA CONFLUÊNCIA ENTRE ARTE, ARQUITETURA E PAISAGEM
}

\author{
I_Le Cabanon: a praia como coisa
}

Uma notícia:

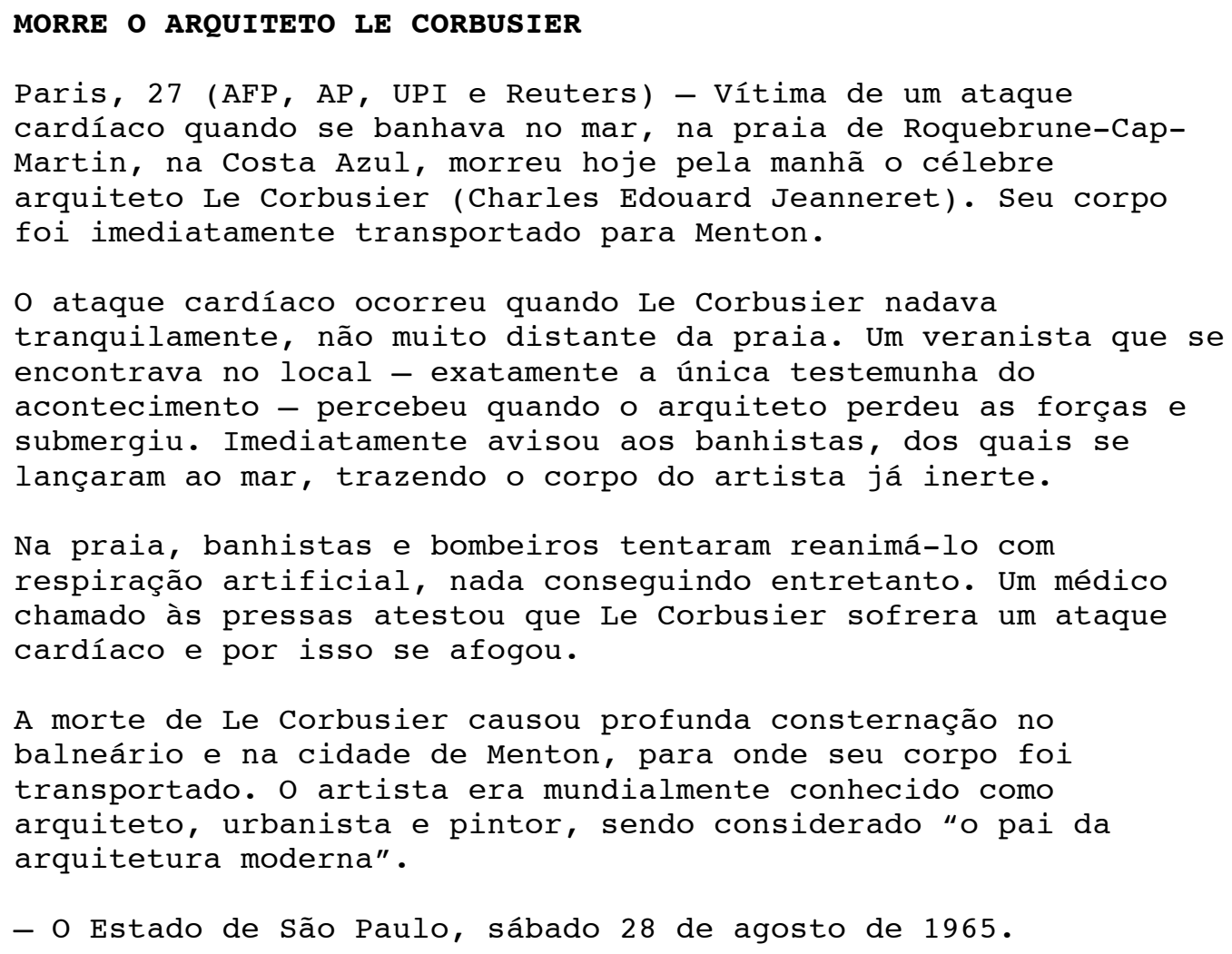

A notícia da morte de Le Corbusier em 1965 traz em si a epítome do homem que decidiu partir pela praia, preconizado pelas palavras de Caymmi: "é doce morrer no mar". Ele se banhava tranquilamente, então podemos imaginar o seu corpo numa posição horizontal, o que remete à sua própria fala sobre a morte: a contradição de partir na horizontal quando se passa uma vida inteira na vertical. Uma apologia à gravidade? A notícia também oscila entre as categorias de arquiteto / artista, confundindo-o entre as duas. Mas o que o levou a Cap Martin foi uma casinha de praia que ele tinha projetado e construído para ele e a esposa passarem os seus verões. Le Cabanon, como era chamado, foi construído por volta de 1952, e nos seus diminutos $15 \mathrm{~m}^{2}$ apresenta uma síntese das ideias de Corbusier: a planta livre, a honestidade dos materiais, a contextualização precisa com o sítio, a articulação balanceada entre arte, arquitetura e paisagem. Le Cabanon também serviu como um protótipo para testar 
suas ideias relacionadas ao Modulor, produzido na mesma época. Assim Corbusier descreve o processo:

Em 30 de dezembro de 1951, em uma mesa de canto em uma pequena lanchonete da Riviera, desenhava como um presente para o aniversário de minha esposa os planos para um "galpão" que construí no ano seguinte em um pedaço de rocha agitado pelas ondas. Estes desenhos foram feitos em três quartos de hora. Eles são finais: não mudou nada. 0 barracão foi construído usando estes próprios desenhos. Com o Modulor, a confiança no processo foi total. 0 interior contém todas as sutilezas que 0 arquiteto pode tirar do bolso. ${ }^{32}$

Le Cabanon poderia ser considerado como uma síntese da relação entre Corbusier e a praia. Situado na vila de Roquebrune-Cap-Martin, da Côte d'Azur, foi implantado vizinho ao seu restaurante favorito, l'Étoile de Mer. Negociando uma co-propriedade com Robert Rebutato, o dono do restaurante, foi decidido que Corbusier poderia ocupar um cantinho do terreno em troca de serviços arquitetônicos para o desenvolvimento de uma série de cabanas turísticas a serem exploradas por Rebutato. Corbusier, desejando um estilo de vida existenz minimum, manteve o programa do chalé reduzido ao mínimo necessário, mas por outro lado aumentou o coeficiente programático da pequena casinha ao incorporar o comer/beber/sociabilizar ao edifício do restaurante, e mais tarde construiu um alpendre no exterior para utilizá-lo como ateliê. Construído com materiais locais, Le Cabanon era constituído de um espaço único que integrava todos os programas do morar, como dormir, ler, trabalhar, descansar, comer, se lavar, etc. A organização espacial estabeleceu-se pelas relações ergonômicas obtidas nos estudos para o Modulor. Alturas, tamanhos, aberturas, passagens foram precisamente calculadas para responderem ao corpo de maneira espontânea e confortável. A posição elevada no morro em relação à praia garantiu uma vista aberta para o mar, expandindo perceptivamente o comprimido espaço do Le Cabanon. Uma grande árvore produzia uma considerável sombra e também oferecia um outro tipo de vizinhança, pois sua presença dialogava com a escala do pequeno edifício.

\footnotetext{
32 Jean Petit, Le Corbusier Lui-même. Genebra: Rousseau, 1970, p. 112, tradução nossa).
} 


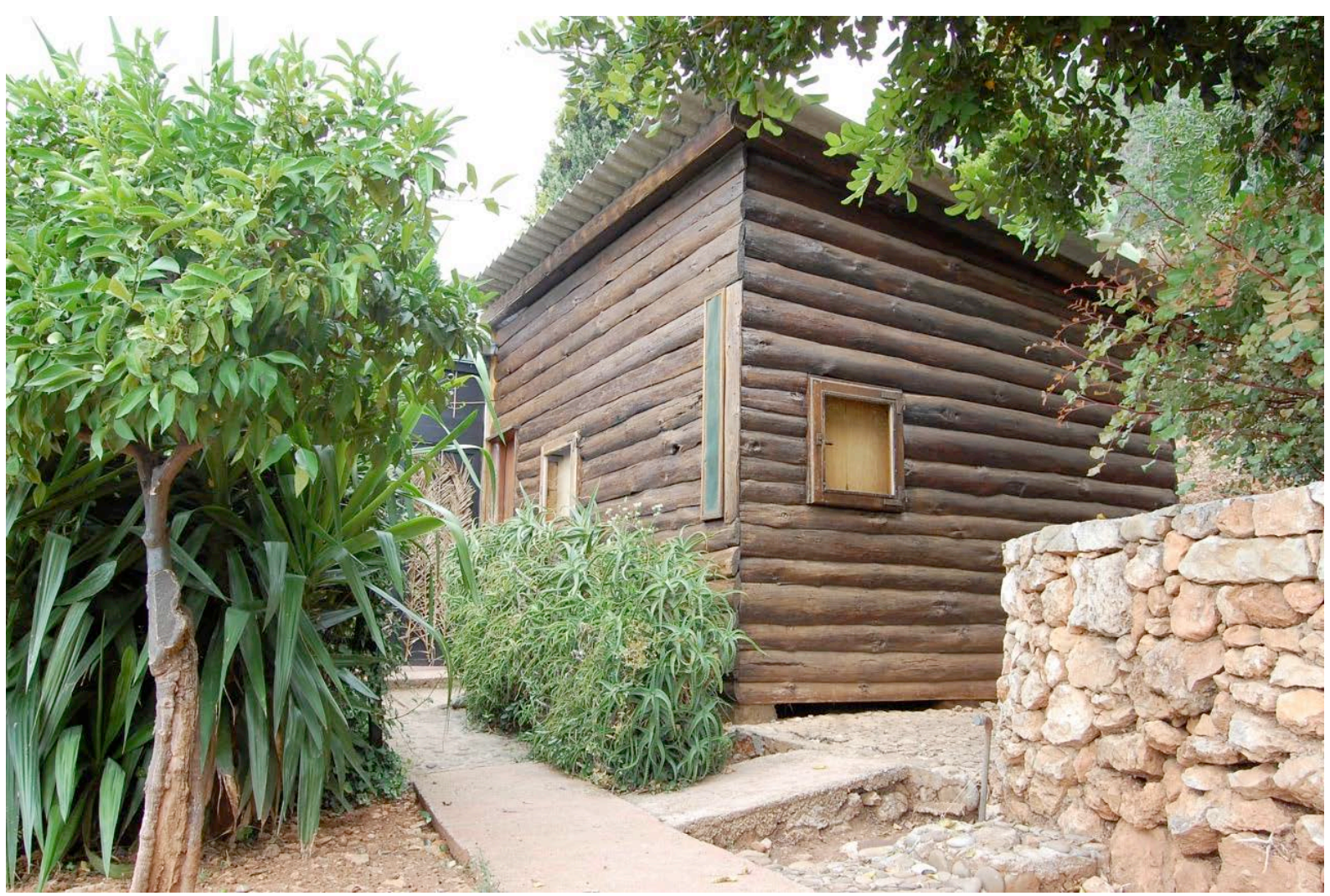

Le Corbusier, Le Cabanon, Roquebrune-Cap-Martin (1951)

O que nos interessa aqui é a aproximação de Le Corbusier com a praia, do desejo de lugar, articulando no interior desta experiência intimista e pessoal o que talvez seja o seu menor edifício. Além do fato de sua morte ter ocorrido numa praia, observamos aqui a sua escolha pela praia, por estar perto do mar. Le Corbusier ficava bastante tempo na praia, especialmente depois dos anos 1940, e é conhecida a sua apreciação em coletar conchas, pedras, refugos, talvez inspirado pelo filósofo e ardente colecionador Paul Valéry, como sugere Niklas Maak. ${ }^{33}$ Especula-se que Corbusier teria mudado a direção no seu racionalismo geométrico inspirado exatamente na cuidadosa observação de outras formas geométricas, aproximadas de uma lógica mais alinhada com a morfologia natural do universo praiano, fato este atestado em Ronchamp e Chandigarh. Costumava também afirmar de que a natureza era a sua fonte de inspiração. Maak propõe que o grande avanço nas ideias de Corbusier, e consequentemente da arquitetura moderna, se iniciou na praia e se radicalizou quando frequentava a praia mais assiduamente durante os anos 1940.

\footnotetext{
${ }^{33}$ Ver Niklas Maak, The Architect on the Beach. Munique: Hirmer Verlag, 2011.
} 


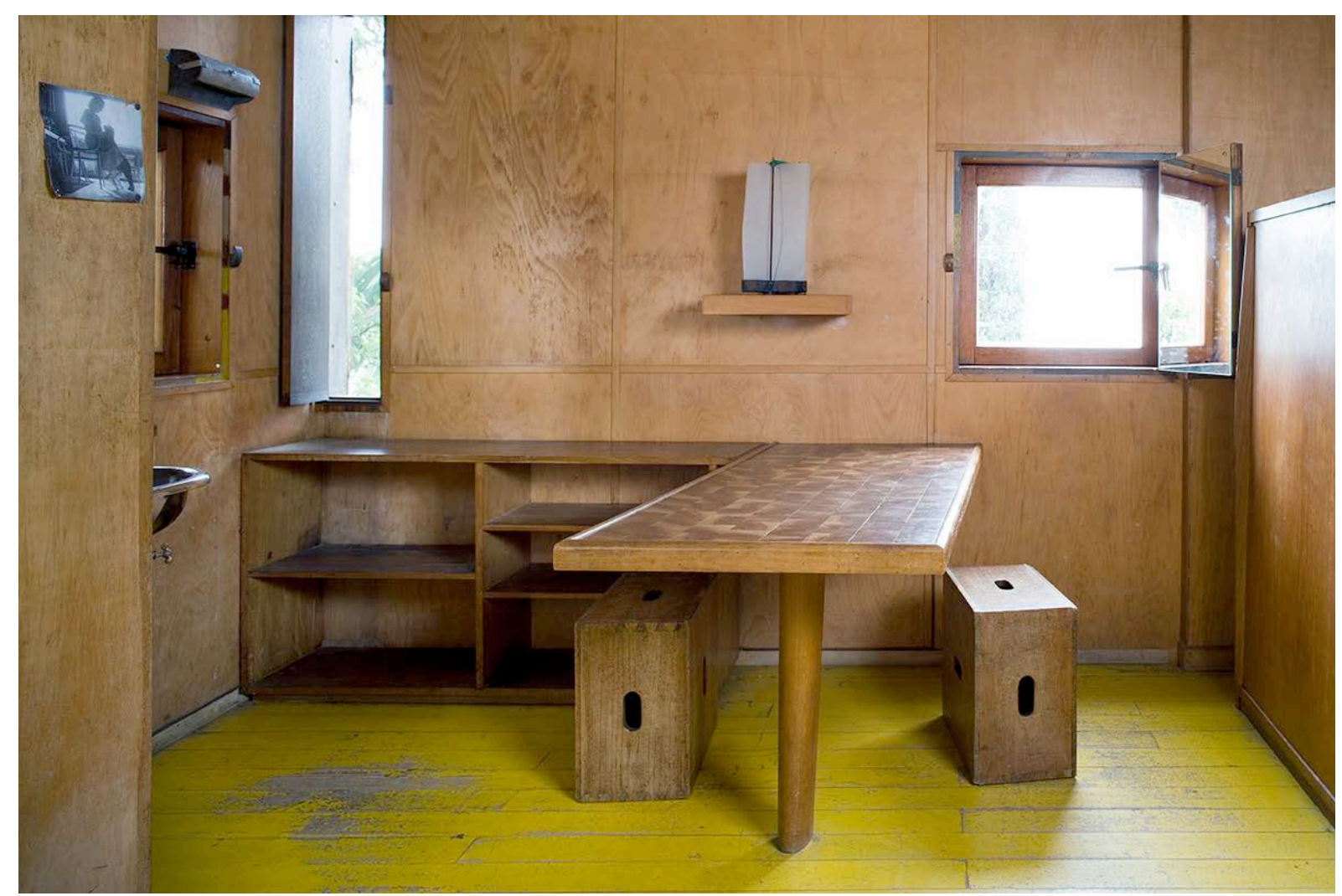

Le Corbusier, Le Cabanon, Roquebrune-Cap-Martin (1951)

Em seu texto Petit Cabanon, a crítica Inês Moreira associa o singelo projeto com a definição de "coisa" da maneira em que foi colocada por Heidegger. Moreira desloca Le Cabanon da sua significação enquanto objeto arquitetônico, distanciando-se da sua representação, linguagem, história, preservação, reconstrução e comunicação, e pensa-o pelo seu inverso, enquanto performance, haja vista os encontros e improvisos do/no espaço no contexto da obra. A “coisa” para Heidegger, explica Moreira, é o lugar definido pela reunião de um conjunto de pessoas com os mesmos interesses e preocupações, organizadas pela mesma causa. Para Heidegger a etimologia germânica de "coisa" (ting), que significa encontro/assembléia, remete à espacialização da causa, isto é, à origem da esfera pública. Seria então a "coisa", ou a "causa", que criaria os recintos públicos e reuniria pessoas em encontros de experiências e, como consequência, tomariam forma os “objetos" arquitetônicos que as alojam. Nesta reflexão, todos os locais relativos ao Le Cabanon formam a espacialização dos temas que reúnem a comunidade em torno do projeto. ${ }^{34}$

\footnotetext{
${ }^{34}$ Inês Moreira, Petit Cabanon. Porto: Dafne lopúsculo 7), 2007, p. 14.
} 
Em Le Cabanon, Corbusier traz para os confins da Riviera Francesa uma lógica urbana e aplica nesta situação específica uma visão de vida pública que não é restrita à ideia de propriedade privada, mas por uma estratégia que almeja uma vida em comum com a sua comunidade, de forma espontânea, informal, ampliando assim o caráter infraestrutural de um pequeno edifício em uma relação de vizinhança integral. Ao compreendermos arquitetura como um ato performático, no sentido de uma maneira de viver, Le Cabanon pode ser considerado a extensão do corpo à arquitetura, do edifício na paisagem, no território, visto que o edifício é desconstruído física, social e politicamente para responder aos âmbitos desta nova proposta de vida. Le Cabanon multiplica-se para além da estrutura do chalé central, incorporando o restaurante e o seu pátio, o alpendre de trabalho, a grande árvore protetora que agora funciona como varanda, o denso paisagismo adjacente, e finalmente a praia como a extensão primordial desta nova vida. Aqui a ideia da casa é transformada na própria totalidade do universo de Roquebrune-Cap-Martin: não se vive mais entre paredes, mas sim no habitar de uma paisagem estendida onde todos estes elementos formam uma arquitetura praiana, comunitária, uma outra ideia de viver-praia.

\section{II_Delirium ambulatorium: a praia como modus operandi}

Em 1978, em um estacionamento da Rua Augusta, em São Paulo, Ivald Granato organizou Mitos Vadios, um evento artístico-experimental de contracultura que pretendia uma saída ao marasmo do confinamento cultural, e como uma crítica cáustica à Bienal de São Paulo, isso tudo durante o ápice dos anos de chumbo da ditadura militar. Era um tempo onde expressões radicais estavam surgindo como reação aos anos pós-Herzog que iniciariam o caminho de volta à democracia. Granato convidou Hélio Oiticica para participar do evento e Oiticica propôs Delirium Ambulatorium, um happening que lançaria a ideia de que cada um poderia "poetizar o urbano".

Além de caminhar pela área da performance, Oiticica pretendia “ambulatoriar”, isto é: "inventar coisas para fazer durante a caminhada". ${ }^{35}$ Para isso levou, do Rio, em sacos, fragmentos de asfalto da Av. Presidente Vargas, terra do Morro da Mangueira, água da Praia

\footnotetext{
${ }^{35}$ Texto-release de Hélio Oiticica de Delirium Ambulatorium acerca de sua participação em Mitos Vadios de Ivald Granato, Programa Hélio Oiticica, Itaú Cultural. Disponível em:

$<$ http://www.itaucultural.org.br/aplicexternas/enciclopedia/ho/index.cfm?fuseaction=documentos\&co $\mathrm{d}=165 \&$ tipo=2>, Acesso em: 18 de maio de 2012.
} 
de Ipanema, entre outros. Na sua participação, Hélio usou óculos de mergulhador, um casaco rosa-choque, sapato de salto prateado, uma camiseta dos Stones, peruca e mais ironicamente vestiu uma sunga, que, pelo seu aspecto inusitado - o seu uso no centro de um espaço totalmente urbanizado e afastado de qualquer referência natural - causou um grande contraste imagético para o evento. Oiticica parecia um super-herói tupiniquim que, no seu deambular crítico-criativo desejava alterar as convenções do espaço público e por ações indeterminadas, mais coniventes com uma atividade na praia, transformava o estacionamento em uma superfície de experimentações.

Todos os ingredientes estavam propostos: o asfalto da Av. Presidente Vargas, a terra do Morro da Mangueira, a água da Praia de Ipanema, os óculos de mergulho e principalmente a sunga nos remetem diretamente ao dizer situacionista: "Sob o asfalto, a praia!” Os procedimentos também: poderíamos compreender o seu “ambulatoriar” com o détournement, a deriva de Guy Debord. Oiticica mais tarde falou:

\section{O Delírio Ambulatório é um delírio concreto. Quando ando e proponho que as pessoas andem dentro de um penetrável com areia e pedrinhas, estou sintetizando minha experiência da descoberta da rua através do andar, do espaço urbano através do detalhe de andar, do detalhe da síntese do andar. ${ }^{36}$}

O andar dentro de um penetrável com areia e pedrinhas alude ao andar na praia, o que instantaneamente transpõe à experiência da rua. $\mathrm{O}$ andar aqui é o perambular, o andar irresponsável sem um objetivo claro, mas com consequências criativas. Frederico de Morais denominou a participação de Hélio no Mitos Vadios como pura "vadiagem artística". ${ }^{37}$ Foi assim, com essa roupa de "tolkens" cariocas que se intrometeu no evento paulista, deslocando assim o universo descompromissado carioca tão distinto da rigidez urbana da paisagem paulista. A vadiagem a que Morais se refere também pode ser associada a outra qualidade da praia: o ócio. Mas o ócio agora está presente no centro da grande capital da produção: a capital do capital. O ócio é porém visto como um vadiar saudável, pois tem nele a intenção crítica junto ao ato criativo. O "ambulatoriar" (em ressonância às outras atividades programadas do Mitos Vadios) transforma o espaço público pela crítica. Um estacionamento, outrora ocupado pelo desejo rodoviarista é agora tomado por H.O. e seus amigos, alterando

\footnotetext{
${ }^{36}$ Cf. Solon Ribeiro, “Mitos Vadios”, Disponível em: <http://solonribeiro.multiply.com/journal/item/3>. Acesso em: 15 de junho de 2012.

${ }^{37}$ Celso Favaretto, A Invenção de Hélio Oiticica. São Paulo: Editora da Universidade de São Paulo, 2000, pp. 224-225.
} 
esta superfície numa praia urbana efêmera, num espaço público transformado, improvisado e indeterminado, pois na deambulação tudo pode acontecer.

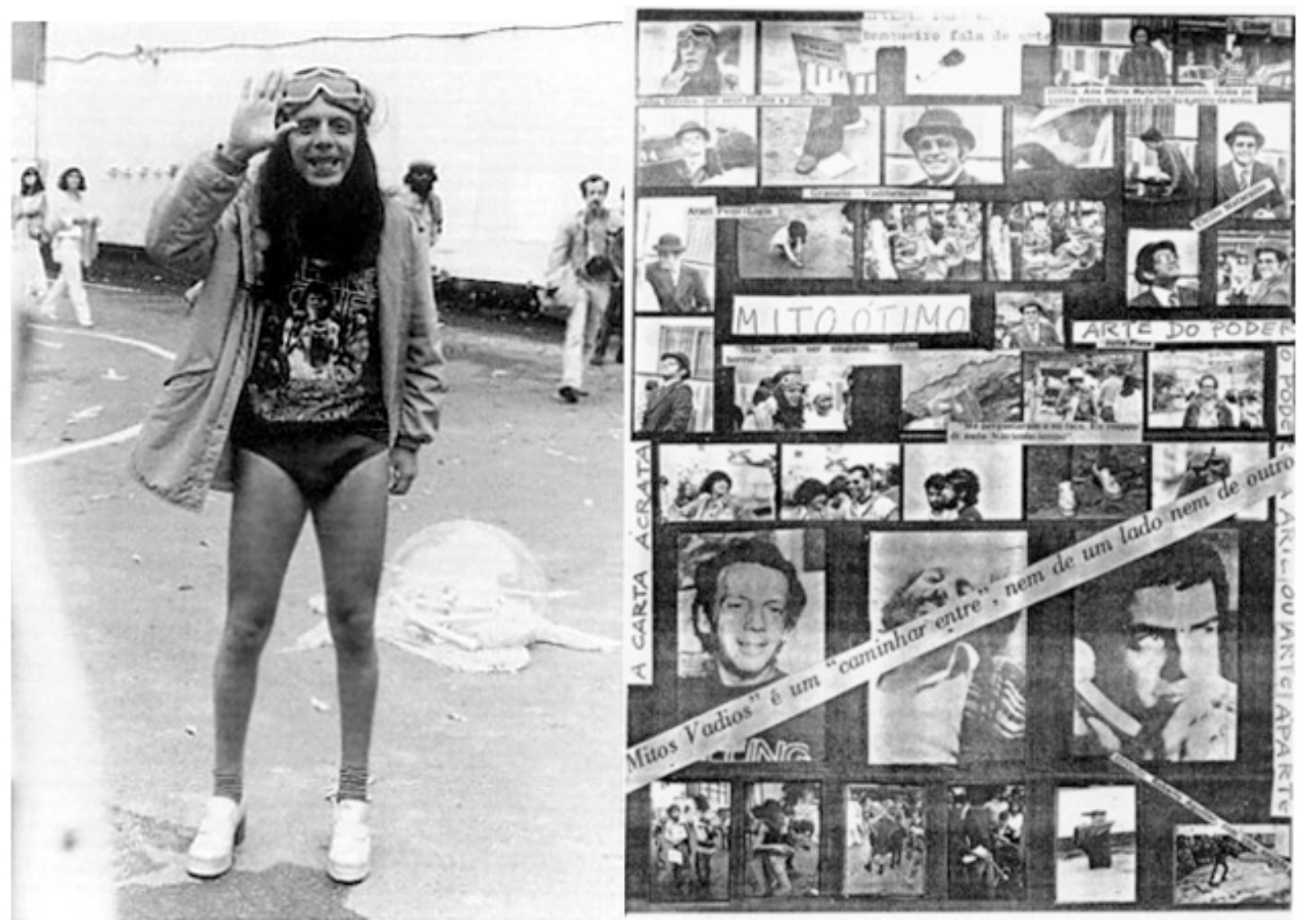

Hélio Oiticica, Delirium Ambulatorium, São Paulo (1978)

Mas no ócio é onde encontramos a motivação central para irmos à praia. Existe uma diferença fundamental entre o ócio e o nada fazer, entre o ócio e a preguiça. O ócio existe para contrabalançar as atividades produtivas, o trabalho de segunda a sexta-feira. O ócio como pausa assume um aspecto criativo pois durante o ócio é que se recuperam as capacidades reflexivas sobre a vida, sobre a razão a respeito daquilo que nos ocupamos. Os sistemas de produção entendem muito bem este processo, haja visto a preservação do fim de semana, da separação entre o trabalho e o lazer. Na sociedade pós-industrial, com o crescimento do individualismo, as distinções entre trabalho e o lazer diminuíram, pois uma parte daqueles que trabalham exercem uma atividade que lhes trazem muito prazer, diminuindo assim as dissonâncias entre produção e descanso. De acordo com Domenico de Masi o ócio dentro do contexto pós-industrial assume o papel de atividade criativa - “ócio criativo" - como sendo uma atividade necessária em relação aos próprios meios de produção: 
Não se trata de preguiça ou desinteresse mas de um estado de graça, comum a várias atividades intelectuais, que se determina quando as dimensões fundamentais da nossa vida ativa - trabalho que produz riqueza, estudo que produz conhecimento, jogo que produz bem-estar - se hibridam e se confundem dando origem ao ato e ao produto criativo... É o estado de espírito que vive um artista quando realiza uma obra de arte, uma criança quando constrói um castelo de areia, um empresário quando guia seu time em direção à uma meta inovadora, um cientista quando conduz com metodologia e tenacidade suas pesquisas... O Mestre na arte da vida faz pouca distinção entre o seu trabalho e o seu lazer, entre a sua mente e o seu corpo, entre a sua educação e a sua recreação, entre o seu amor e a sua religião. Ele dificilmente sabe distinguir uma coisa da outra. Ele simplesmente persegue sua visão de excelência em tudo que faz, deixando para os outros a decisão de saber se está trabalhando ou se divertindo. Ele acha que está sempre fazendo as duas coisas simultaneamente. ${ }^{38}$

A praia dentro deste contexto de produção capitalista assume o papel de palco para aqueles que praticam o ócio criativo, pois ela não é somente um destino final mas é também um meio de criatividade. Então, atividades como leitura, encontro, conversa, contemplação, relaxamento, distração, o não-fazer-nada são na verdade ações indiretamente relacionadas às atividades de produção, e altamente influenciadoras da qualidade de vida do trabalhador, e da qualidade final daquilo que é produzido. Portanto a praia atua inconscientemente no processo de significação das ocupações que se dão fora do seu contexto de produção. No caso de Copacabana, por exemplo, por ser uma praia localizada no centro de uma metrópole produtiva atrai um grande contingente daqueles que participam dos processos de produção, naturalmente transformando-se num palco ideal para a prática do ócio criativo. Neste ambiente de lazer estas distinções ficam muito menos evidentes até para aqueles que estão imersos em atividades produtivas como donos de barracas e camelôs, pois o ócio vira também a base de uma economia informal, enquanto a praia alivia as pressões sobre o trabalhador. Trabalhar na praia não seria melhor do que trabalhar em uma linha de produção industrial? Não só em Delirium Ambulatorium mas em toda a produção de Hélio Oiticica a imagem do ócio criativo fica evidente, ou reiterando Frederico de Morais: "vadiagem artística". Mais do que uma atividade paralela à sua produção Oiticica utiliza o ócio como material central do seu trabalho. E é por isso que encontramos tantos paralelos entre a sua obra e o brincar, o jogar, o dançar, o deitar, o contemplar, exprimindo "o estado de espírito que vive um artista quando realiza uma obra de arte".

\footnotetext{
${ }^{38}$ Domenico de Masi, Ócio Criativo. Disponível em: <http://www.domenicodemasi.it/pt/paradigma/\#oziocriativo>. Acesso: 10 de agosto de 2013.
} 
Existe o ócio, mas também o palco onde o ócio é praticado, sendo a praia um exemplo notável. Mas em geral as nossas queridas cidades, sempre generosas em alimentar os nossos desejos, em acomodar a ânsia moderna de viver juntos, deveriam receber um tratamento em troca, no mínimo à mesma altura em que inspiraram e apoiaram as manifestações de Mitos Vadios. A congestão urbana, às vezes insuportável, no limite do "ser" humano na cidade, força-nos a considerar o espaço público não mais como terrain vague simplesmente, resultado acidental do crescimento urbano, mas sim como um lugar capaz de traduzir o "público" dos espaços públicos em reais possibilidades de ação. Para Ignasi de Solà-Morales, a ideia do terrain vague ${ }^{39}$ não se limita à identificação de vazios urbanos sem programas definidos, e sim aborda o reconhecimento das potencialidades destes espaços urbanos residuais, como, por exemplo, um estacionamento. Neste sentido terrain vague são as potencialidades que habitam estes espaços, e não o caráter existente do espaço em si. Num mesmo sentido o ócio também demonstra as potencialidades que habitam a criatividade humana, e não o caráter existente de cada um.

A intencionalidade de Mitos Vazios, qualquer que seja, aponta para a transformação lúdica de um espaço urbano, que, pela duração daquelas horas, se tornou, dentro dos seus limites e loucuras, um paraíso urbano. Tais sensibilidades, provindas dos mistérios e imaginários dos nossos espaços domésticos e interiores, das nossas deambulações cotidianas e anônimas, traduzidas nas mais intrigantes obras de arte, como Delirium Ambulatorium, poderiam influenciar de modo mais direto a produção e gestão destes espaços. Essa energia que emana de tantos gestos poéticos, gerados pela própria experiência humana na urbis, influenciariam as máquinas que regem a tecnoburocracia das nossas cidades, determinando um outro desenho para os espaços urbanos. Se o artista moderno foi capaz de fugir do calabouço das instituições e ir para a rua, será que o próximo passo não seria retornar e mudar estas mesmas instituições num ato coletivo subversivo à la Augusto Boal? Paola Berenstein Jacques identifica e elege em Hélio Oiticica o porta-voz do nosso delírio urbano, sugerindo que talvez o sonho de um espaço urbano mais poético seja possível:

Talvez a maior crítica dos errantes urbanos [artistas] aos urbanistas [tecnocratas], tenha sido exatamente o que Oiticica resumiu de forma tão clara em "poetizar o urbano". Os urbanistas teriam esquecido, diante de tantas preocupações funcionais e

\footnotetext{
${ }^{39}$ Ignasi de Solà-Morales, "Terrain Vague”. In Anyplace. New York: Any Corporation / Rizzoli, 1995, pp. $118-23$.
} 
formais, deste potencial poético do urbano, algo tão simples, porém imprescindível, principalmente para os amantes da cidade. ${ }^{40}$

E Hélio Oiticica, admirador de Mondrian e amigo de Gullar, que embarcou na grande aventura da modernidade do século 20 , que abraçou de modo lúcido toda a mobilidade das experiências estéticas do período, que se desdobrou em tantos para substanciá-las e sintetizálas em atos poéticos plenos de resplendor; pela recepção das impressões sensoriais da cidade e da vida, deslocando-as do plano dos Monocromáticos para a presença dos Bólides, da representação dos Metaesquemas para o ato performático dos Parangolés, de dentro dos Núcleos para fora das arquiteturas das Tropicálias Subterrâneas, da casa dos Penetráveis para a rua das Cosmococas, e para as urbanidades de Agripina é Roma Manhattan, de um indivíduo (o persistente de-ambulante) para o outro (o constante agente), de Jerônimo da Mangueira até Lygia Clark - nos presenteia:

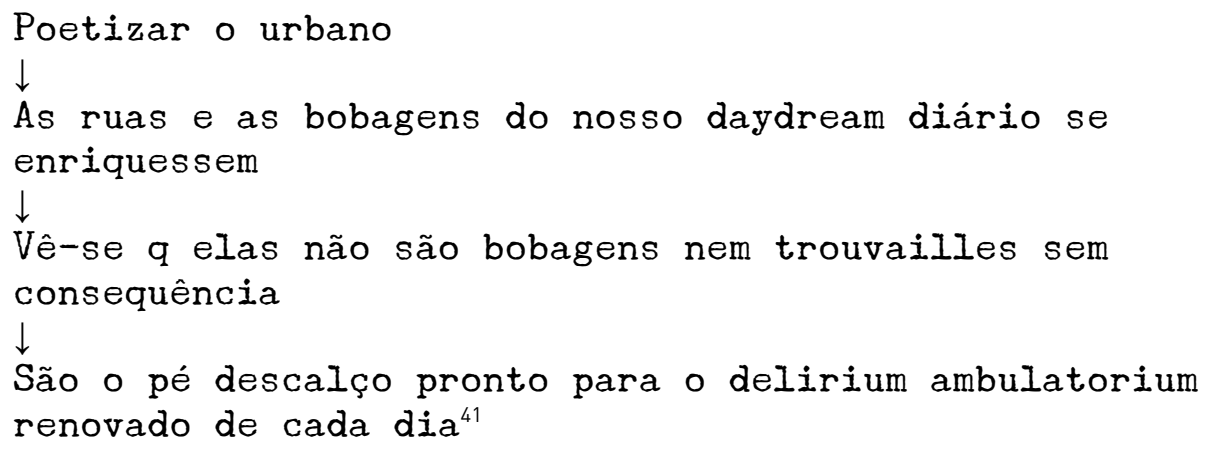

Na transgressão do processo de Oiticica a praia está plenamente presente em suas diversas formas. Estas expressões não se baseiam numa alusão icônica-metafórica direta da imagem da praia, mas sim no potencial poético-público que a praia carioca oferece. Desde o modelar dos seus Bólides, com suas areias de cores extasiantes, até às suas Tropicálias, que tão incisivamente trouxeram a paisagem praiana para dentro do museu, e consigo trazendo também o deambular e o ócio para dentro da instituição. Neste delirium ambulatorium cotidiano ele propõe uma praia urbana nos Jardins, como a que foi manifestada em Mitos

\footnotetext{
${ }^{40}$ Paola Berenstein Jacques, "Elogio aos errantes: Breve histórico das errâncias urbanas", 2004. <http://www.vitruvius.com.br/arquitextos/arq000/esp256.asp.> Acesso em: 18 de fevereiro, 2012.

${ }^{41}$ Hélio Oiticica, Eu em mitos vadios, Ivald Granato, 1978 (original de Oiticica). Disponível em: $<$ http://www.itaucultural.org.br/aplicexternas/enciclopedia/ho/index.cfm?fuseaction=documentos\&co $d=462 \&$ tipo=2>. Acesso: 8 de fevereiro 2012.
} 
Vadios, mas por extensão, ele propõe a praia mais do que um novo lugar na cidade: a praia como uma nova atitude, a praia como modo de vida, a praia como modus operandi na cidade.

\title{
III_Barravento: a praia como narrativa
}

\begin{abstract}
Grande extensão do céu. Nuvens vão correndo, fecham escuras e pesadas. Superfície do mar encapelado. Palhas de coqueiro agitam. Camisa do pescador agita sob o vento. Espumas formam um "carneirinho" sobre as águas. Pescador. A mão sobre o olho volta o rosto para cima. Movimento. Nuvem cobre o sol totalmente. Trazido pelo o açoite da onda, o rosto do pescador avança para a objetiva. 0 pescador foge de costas, levado pela onda. Equilibra-se por cima da jangada. Mar fechado. Jangada perdida no meio, como minúsculo ponto. Tempo fechado, violento... Um jorro d’água lava o rosto do pescador. Onda alta para a objetiva. A onda. A onda quebra envolvendo tudo. ${ }^{42}$
\end{abstract}

Estas são as primeiras linhas do roteiro de Barravento, primeiro longa-metragem de Glauber Rocha, filmado em 1962 na praia de Buraquinho, a alguns quilômetros ao norte de Salvador da Bahia. A narrativa de Barravento descreve o drama de uma vila de pescadores de xaréu, descendentes de escravos vindos da África, que traziam com eles os antigos cultos místicos associados ao candomblé. ${ }^{43}$ A história se concentra nos conflitos criados a partir do retorno de Firmino, que abandonara a vila fugindo para Salvador com o intuito de se livrar da pobreza. O seu retorno altera o ambiente sereno do lugar, criando conflitos não só sociais, mas também de natureza política, sexual e religiosa, afetando assim profundamente a estabilidade da cultura local.

Já na sua gênese a obra de Glauber demonstra uma clara intenção de articular, através de uma narrativa mística, o microcosmo da sociedade brasileira e suas questões, especialmente em se tratando de um momento tão conflitante como aquele em que o filme foi realizado (os anos 1960). A esquizofrênica ideologia e crítica glauberiana contrabalança um profundo sentimento religioso e o desejo de avançar o ideário marxista. Contudo, o que nos interessa está aquém da história de Firmino: Barravento acontece quase que exclusivamente,

\footnotetext{
${ }^{42}$ Glauber Rocha, (Orlando Senna, org.). Roteiros do terceyro mundo. Rio de Janeiro: Alhahambra Embrafilme, 1985, p. 49.

${ }^{43}$ Barravento é o termo no candomblé que se refere ao estado de estonteamento que precede a posse da filha ou filho-de-santo pelo orixá, caracterizado por transe com movimentos descoordenados, agitação, tremores e também ao toque rápido de tambores que produz esse estado. Para a mais completa leitura crítica de Barravento ver Ismail Xavier, "Barravento: Glauber Rocha, 1962, alienação versus identidade" [1983]. In Sertão Mar: Glauber Rocha e a estética da fome [São Paulo: Cosac \& Naify, 2007].
} 
totalmente na praia. A praia como cenário torna-se central à narrativa, e não somente um coadjuvante, um pano de fundo com o qual os atores se deparam. No filme, o termo "barravento" é expandido também como uma ideia de paisagem, referindo-se à agitação do mar e dos ventos, aos movimentos dos coqueiros, elemento conector da terra ao céu, à superfície da areia como território de todas as possibilidades e contradições sociais, o mar como gerador de economias e enigmas, e assim por diante. Esta relação entre corpo e paisagem, entre o artista e o lugar, faz da praia um ator fundamental e integral na estrutura da narrativa.

A predominância da praia como elemento estruturador da narrativa é um artifício épico na visão do cineasta, inserindo-a, como resultado, na consciência e imaginários da audiência. Em contrapartida é surpreendente observar quão inconsciente é o papel da praia no próprio processo de reflexão e expressão da construção civilizatória brasileira. Com uma presença possante e definidora dos comportamentos e sentidos da cultura brasileira, a praia ainda ocupa uma presença marginal nas discussões críticas sobre a formação do espaço brasileiro. Talvez de tão próxima, não podemos vê-la apropriadamente. Glauber sempre posicionou-se neste espaço crítico através da sua libertina "militância político-ideológica de efeitos imediatos, num contexto de reivindicações pela reforma urgente da sociedade brasileira" ${ }^{44}$ Daí sua capacidade poético-heróica de poder compreender o potencial da praia como expressão criadora.

Mas é claro que a praia, então como expressão artística popular, não está presente somente em Barravento. Existem exemplos da presença da praia em outras produções artísticas, como nas canções de Dorival Caymmi, nas pinturas de Carybé, ou nas histórias de Jorge Amado. Estas expressões pitorescas, mais graciosas e envolventes, mais próximas da sensibilidade das gentes, contrastam com a apreensão da praia numa vertente mais glauberiana, isto é, como manifestação crítica de vanguarda. Glauber, ao invés de descobrir a praia com a simples candura que a vida praiana sugere num primeiro momento, sublime e contemplativa, utiliza-a como um vértice veemente na problematização das complexidades da vida brasileira, propondo soluções estilísticas que vão além de uma imagem aparente e precipitada, tornando-se um espaço crítico. O que Barravento oferece é esta posição crítica, ou seja, ao olharmos o espaço da praia do ponto de vista da arte e da arquitetura, deveríamos também nos orientar através de manifestações que superem o comum e o ordinário, o puro

\footnotetext{
${ }^{44}$ Idem, Ibid.
} 
comercial, o esperado. Ao incorporar uma atitude crítica como em Barravento, lidando com os imperativos do engajamento e dentro de uma escassez de meios (para não falar de um sentido premente de urgência), visualizamos uma problematização da praia localizada em soluções estilísticas que esbocem as suas complexidades.

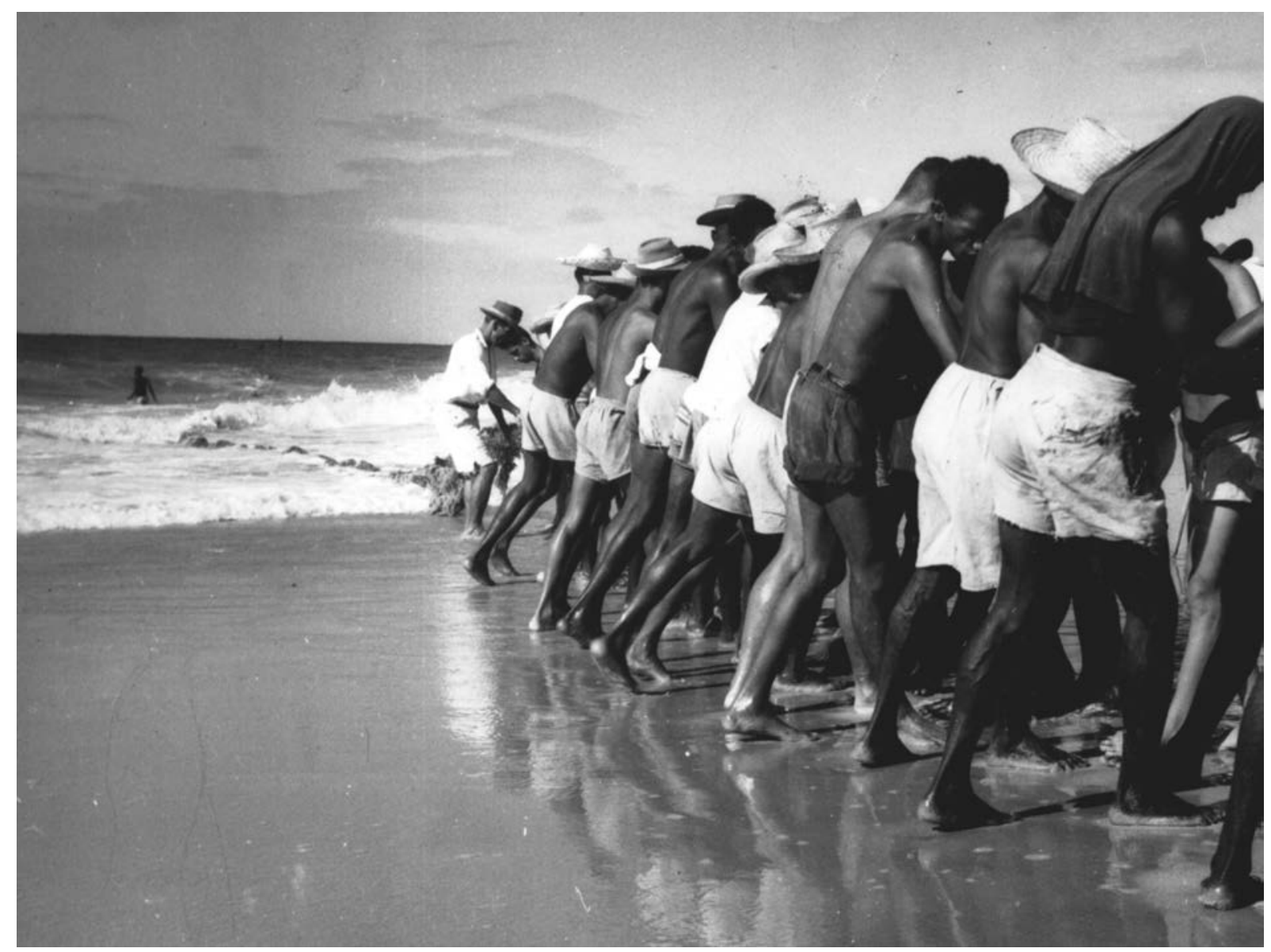

Glauber Rocha, Barravento (1962)

Como o Le Cabanon de Corbusier traz para Roquebrune-Cap-Martin uma lógica urbana num cenário bucólico e aplica a esta situação específica uma visão de vida pública, assim o faz Oiticica em Delirium Ambulatorium, trazendo a lógica da praia para o cerne da vida urbana. Em Barravento, esta transição entre a praia e o urbano só é alimentada pela imaginação de Firmino que deixa a vila para se estabelecer na cidade. A consciência da cidade se dá pelo invisível, pela ausência, suspendendo qualquer certeza de uma vida melhor fora de Buraquinho. A totalidade da vida se dá na praia: nascimentos e mortes; disputas e encontros; amor e sexo; trabalho e descanso; meditação e neurose são eventos cotidianos em Barravento. A vida em comunidade na praia não é uma escolha, mas um estado a fortiori da existência. A 
praia em Barravento não oferece uma condição de vida: ela é a própria vida, o protagonista do filme, um realismo sujo dificílimo de se escapar. ${ }^{45}$

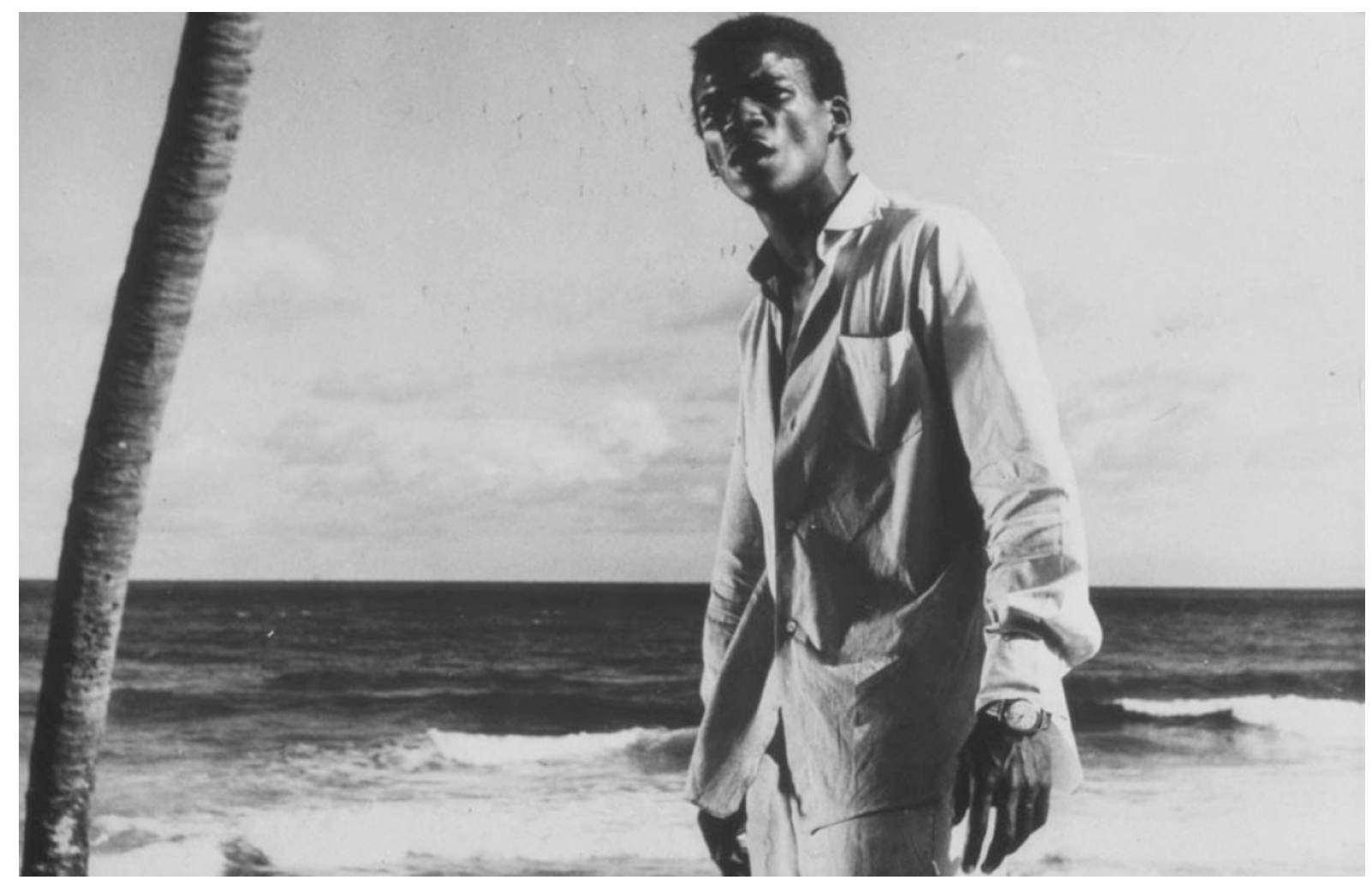

Glauber Rocha, Antonio Pitanga (Firmino) em Barravento (1962)

Por contraste, no Le Cabanon e em Delirium Ambulatorium a condição onírica da praia é recuperada e utilizada como tática para a conquista do desejo de uma vida em comunidade num espaço radicalmente modificado. Neles a praia manifesta-se de forma espontânea, informal e lúdica, ampliando o caráter infraestrutural de espaços estagnados (um pedaço de terreno ao lado de um restaurante / um estacionamento vazio num fim de semana) que esperam por uma injeção de intensidade. O caráter infraestrutural é identificado nos dois projetos: um pequeno edifício que se considera a extensão da paisagem integrado à sua

\footnotetext{
45 “Realismo sujo é um tipo de trabalho de ficção de uma nova geração de autores americanos. Eles escrevem sobre o lado sombrio da vida contemporânea - um marido abandonado, uma mãe solteira, um ladrão de carros, um batedor de carteiras, um viciado em drogas - mas escrevem sobre isso com um distanciamento perturbador, às vezes beirando a comédia. Discreto, irônico, às vezes selvagem, mas com uma compaixão insistente, essas histórias constituem uma nova voz na ficção." Bill Buford da revista Granta, descrevendo o movimento no verão de 1983. Charles Bukowski talvez seja o originador do gênero. Disponível em: <http://www.granta.com/Archive/8.>. Acesso em: 16 de junho de 2012.
} 
vizinhança; uma superfície bruta, estendida e anônima de um estacionamento convertido em uma praia urbana.

Em Le Cabanon e Delirium, o objetivo derradeiro é a conquista de um equilíbrio entre o lúdico e o ócio. Em Barravento, a narrativa acentua as razões políticas de disputa e a alienação mística dos seus habitantes a partir de um terreiro de polêmicas, nada onírico, lúdico, ou ocioso. A praia em Barravento se apresenta em constante tensão, pois sua superfície está permanentemente ativada pelas contradições e lutas sociais que afligem a comunidade. Barravento oferece um contraponto efetivo ao olhar consumista da praia, removendo quaisquer resquícios idealistas de classe média, que vai à praia como um destino paradisíaco. A abordagem neorrealista de Glauber não deixa dúvidas quanto às condições contrastantes entre estas duas imagens díspares de um mesmo objeto. Objeto este tão fantasiado pelo imaginário brasileiro.

Quanto ao Le Cabanon e Delirium Ambulatorium, os dois projetos se definem como um ato performático, como foi sugerido por Moreira: possibilidade de uma arquitetura performática. Os dois propõem uma outra maneira de viver, numa posição diametralmente oposta àquela de Barravento, isto é, uma outra ideia sobre a paisagem da praia, com a inserção da "coisa" na paisagem, no território, na cidade, incorporando todas as potencialidades do conjunto para assim alterar a sua arquitetura. Os dois projetos, dentro das particularidades contrastantes dos seus contextos, decodificam a praia como a extensão primordial desta nova vida, de uma vida impossível em Barravento, mas que aqui é realizada como uma nova perspectiva. Le Cabanon / Delirium Ambulatorium / Mitos Vadios indicam outras formas de habitar o mundo e consolidam uma confluência entre arquitetura, espaço público e arte, desafiando os seus próprios limites disciplinares. ${ }^{46}$ A proposta é liberar a arquitetura de seus próprios confinamentos e compreendê-la como um território estendido habitável, onde todos os elementos disponíveis - as potencialidades do terrain vague — formam uma infraestrutura comunitária, e admitindo a praia como tática lúdica direta, propõe uma outra ideia de viver, o viver-praia, uma nova imagem da vida pública na cidade. Se por um lado Barravento distancia-se da praia enquanto desejo, mas a apresenta como território real de disputa de classe, Le Corbusier e Oiticica oferecem a oportunidade da reinvenção lúdica do

\footnotetext{
${ }^{46}$ Tanto Le Corbusier quanto Hélio Oiticica compreendiam intuitivamente as relações entre arte e arquitetura. Le Corbusier era um artista realizado, e Hélio era um artista que engajava e discutia a arquitetura no seu trabalho, fazendo assim ambos exímios experimentadores transdisciplinares.
} 
território transpondo os limites de suas respectivas disciplinas e das próprias convenções sociais, e no processo criam campos dinâmicos - praiapaisagens.

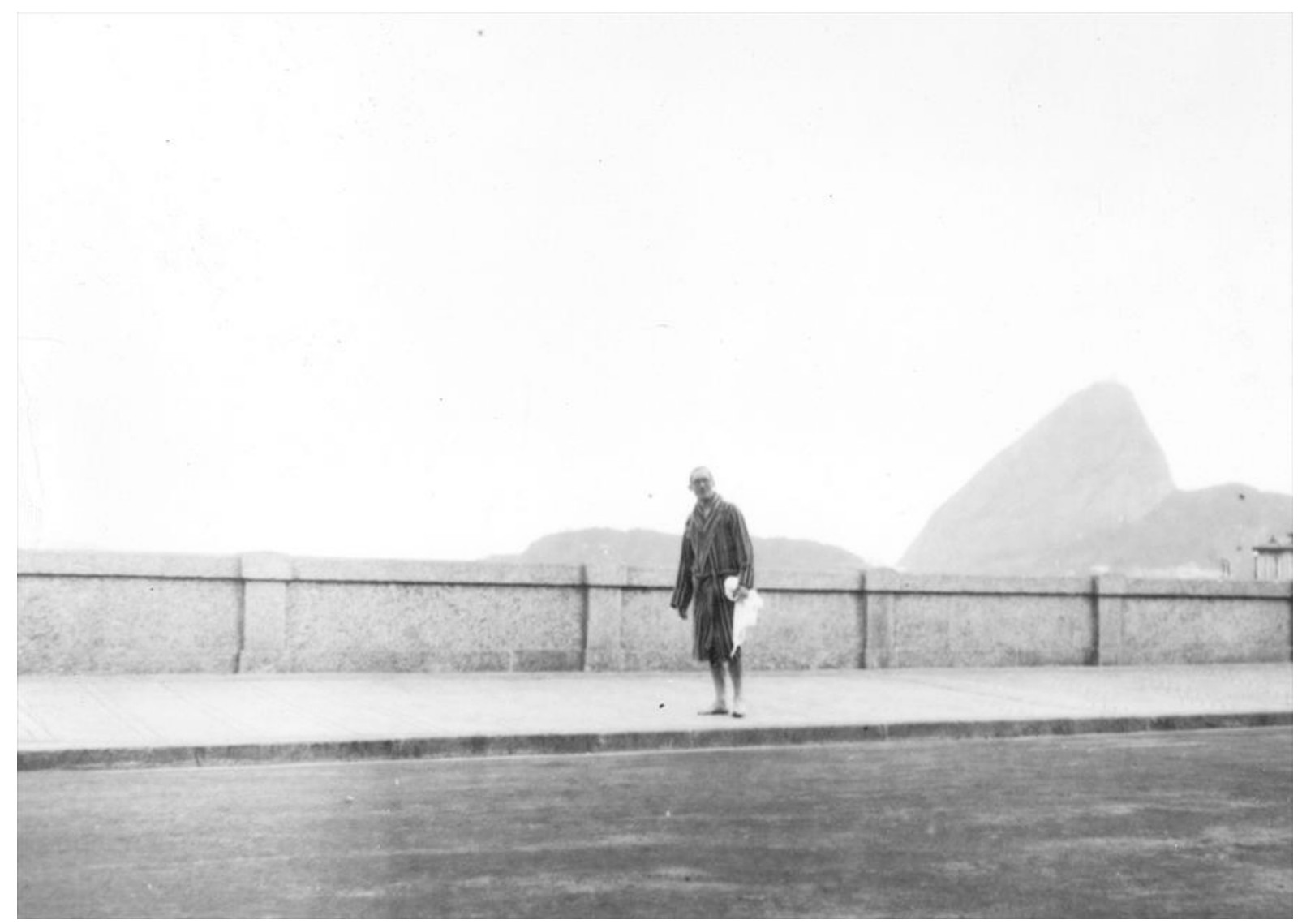

Le Corbusier no Rio de Janeiro, Fondation Le Corbusier (1929) 


\title{
4_A PASSAGEM DO ATELIER PARA A RUA: DO OBJETO PARA A SUPERFÍCIE
}

A contextualização e construção do conceito praiapaisagem em termos dos seus antecedentes históricos pode ser traçada a partir das vanguardas do século 19 e de certa forma a evolução da modernidade mapeia a sua progressão até às questões contemporâneas como a arte relacional e a reinvenção das infraestruturas urbanas, enquadrando a questão do espaço público como prática artística numa linhagem histórico-teórica, bem como ampliando o contexto da discussão da praia em relação à arquitetura através de conceitos como campo, infraestrutura, urbanismo interior e paisagem-urbanismo. Mas qual foi a origem desta enorme atração humana para o mar, para a praia?

\section{I_ 0 crescimento das cidades e as práticas artísticas}

\begin{abstract}
Os meios de apreciar o mar com a visão das populações que habitavam as suas margens não eram apenas uma questão de hábito individual, nível cultural ou sensibilidade. A maneira de estar juntos, a cumplicidade entre os turistas, os sinais de reconhecimento e os procedimentos em criar distinções também determinaram os meios de desfrutar este lugar. As maneiras em que o tempo foi utilizado e o espaço construído foram moldadas pelas formas organizadas de sociabilidade e, em seguida, distribuídas pelas frentes marítimas. A gama de distrações, prazeres e obrigações que resultaram ditou a forma da beira-mar, então ainda incipiente. É interessante ponderar como este novo cenário social desenvolvido foi estimulado pelo desejo de desfrutar da praia, e como as primeiras práticas foram reformulados de acordo com esta nova finalidade. ${ }^{47}$
\end{abstract}

A utilização da praia como superfície ocupada de lazer, como um espaço público legítimo consolidou-se com o desenvolvimento inicial da metrópole moderna, a partir das transformações ocorridas na Paris do século 19, com as primeiras ocupações da praia como o intuito de lazer. Independentemente da evolução capitalista via revolução industrial a congestão urbana indicou claramente um desejo coletivo de habitar junto, de viver junto, resultando em acúmulo populacional urbano. Nota-se que foi na mesma época que a noção da praia como destino turístico também amadureceu, mas agora como destino longe da cidade, criando assim a estância balneária. Tanto a praia urbana como a estância balneária foram consequências do rápido crescimento urbano entre a segunda metade do século 19 até o início do século 20. Este processo de urbanização foi também calcado por um processo de crescimento em urbanidade - não só viver junto, mas viver junto com dignidade e civilidade

\footnotetext{
${ }^{47}$ Alain Corbin, “Inventing the Beach”, The Lure of the Sea: The Discovery of the Seaside 1750-1840. London: Penguin Books, 1995, p. 250, tradução nossa.
} 
— indicando que as oportunidades sobre o solo urbano não eram somente categorizadas pelos novos modos de produção, mas propunham uma nova qualidade de vida, com novas oportunidades para uma vida emocionante, eletrizante na cidade, e especialmente com uma nova sociabilidade, como Alain Corbin propõe. O flâneur de Charles Baudelaire surgiu como uma das primeiras manifestações poéticas desta nova condição urbana e protagonizou um dos braços das vanguardas do século 20 ao sugerir o potencial da rua e dos espaços públicos como locus e material para as novas expressões artísticas. Não podemos esquecer que o flâneur é uma síntese do ócio, daquele que, na cidade, decide perambular sem objetivos nenhum, removendo-se da estrutura produtiva urbana, mas paradoxalmente ativando o espaço urbano com o seu ócio particular.

$\mathrm{Na}$ oclusão entre o surgimento da praia como espaço público e a metrópole moderna a partir da experiência de Paris criou-se um evento paralelo entre estes dois fenômenos: uma atitude moderna perante a cidade. Começando por Baudelaire algumas práticas foram fundamentais para a consolidação do espaço público como agente e suporte das novas atitudes. O desenvolvimento de tais práticas invadiu o campo do urbanismo, focado agora em responder aos drásticos movimentos do solo urbano devido ao seu adensamento físico, às infraestruturas urbanas e às implicações das exigências sociais e psicológicas da nova metrópole. ${ }^{48}$ Tais práticas - as artísticas de vanguarda, o urbanismo e a psicanálise - se desenvolveram considerável e simultaneamente com o crescimento das complexidades da metrópole e da vida moderna, e, em um contexto paralelo, laços se formaram em relação à própria evolução da praia enquanto elemento cultural urbano. Observando tais relações podemos compreender a praia e os seus antecedentes históricos segundo os seus principais condicionantes para assim poder articular a sua dimensão contemporânea, e desenvolvendo no processo praiapaisagem como tática aplicada ao espaço público.

Com o desenvolvimento da metrópole do século 20, e a consequente concentração humana e de capital, observou-se um fenômeno novo na história das práticas artísticas deste período. Apoiados por atitudes vanguardistas, a arquitetura e o urbanismo se distanciaram da instrumentalização industrial e dos processos de produção, e, adotados por artistas, estabeleceram-se como um novo aparato, como uma estratégia emancipada de criação artística. A arquitetura sempre foi uma disciplina conectada à industria e à produção, mas,

\footnotetext{
${ }^{48}$ Ver Georg Simmel, “The Metropolis and Mental Life”. In Simmel, The Sociology of Georg Simmel. London: Mcmillan, 1950.
} 
mantendo-se autônoma o suficiente para ser considerada também uma forma poética e artística, integra o percurso da história da estética. Governos, sistemas políticos e economias se utilizam da arquitetura não só para a estruturação de condições sociais (habitação, saúde, serviços), de produção (industrias, comércio, educação), e governo (instituições, parlamentos, cultura), como parte de uma evolução socio-técnico-científica, mas também como instrumento ideológico. Poderíamos então conceber a arquitetura e o urbanismo como disciplinas desvinculadas da tradição do uso e da indústria da construção, das cidades como simples infraestrutura, assumindo uma autonomia no campo das significações e da estética. Poderíamos então considerar a pressão dos novos modos de produção como a energia geradora desta nova atitude, adotando agora o edifício ou do desenho urbano um novo status de obra de arte?

Esta nova autonomia da arquitetura espalhou-se pelos grandes centros da Europa e das Américas, e, apoiada por ideologias visionárias - incluindo o Construtivismo russo - virou uma forma habitual para a um segmento da vanguarda que reconheceu na técnica da arquitetura e do urbanismo uma possibilidade de transformação social, possibilidade que outras práticas já haviam adotado, incluindo a escultura e a pintura. De repente as técnicas tradicionais podiam referir-se como arte, respondendo a outros avanços na sociedade. Este poder formal da arquitetura produziu variantes que estenderam as possibilidades estéticas do objeto de arte incluindo elementos formais, técnicas construtivas, alterações de escala, presença fenomenológica e cromáticas distintas. Tais aproximações formais da arte com a arquitetura viraram ocorrência comum, e podiam ser observados no trabalho de vários artistas - das colunas de Constantin Brancusi às estruturas suprematistas de Kazimir Malevich; das construções excêntricas ou contra-construções de Theo van Doesburg aos monumentos de Vladimir Tatlin; dos espaços ortogonais de Gerrit Rietveld ao plasticismo pictórico de Le Corbusier; das cenas imaginárias de El Lissitzky às arquiteturas visionárias de Ivan Leonidov. Em todas estas manifestações, ficou evidente que o traspassamento entre arte e arquitetura - artistas se utilizando de técnicas e valores formais frequentemente ligados à prática da arquitetura / arquitetos consolidando qualidades conceituais e materiais tradicionalmente conectados às práticas artísticas — tornou-se parte de um sistema criativo comum. A arquitetura não mais necessitava restringir-se aos caprichos dos governos, dos magnatas ou da indústria. Quanto à cidade, ela se postou como uma geradora de experiências estéticas para aqueles que se lançaram à ela. As oscilações estéticas, ideológicas e políticas 
motivaram os arquitetos a se desvincularem dos tradicionais processos de produção da arquitetura, criando uma nova autonomia do objeto. Art Nouveau é um grande exemplo para este caso, pois serviu de um ressurgimento do ornamento, agora em profunda integração do feitio artístico-escultórico através das suas formas orgânicas com a essência arquitetural do edifício, portanto afirmando a não-existência de separação entre arte e arquitetura.

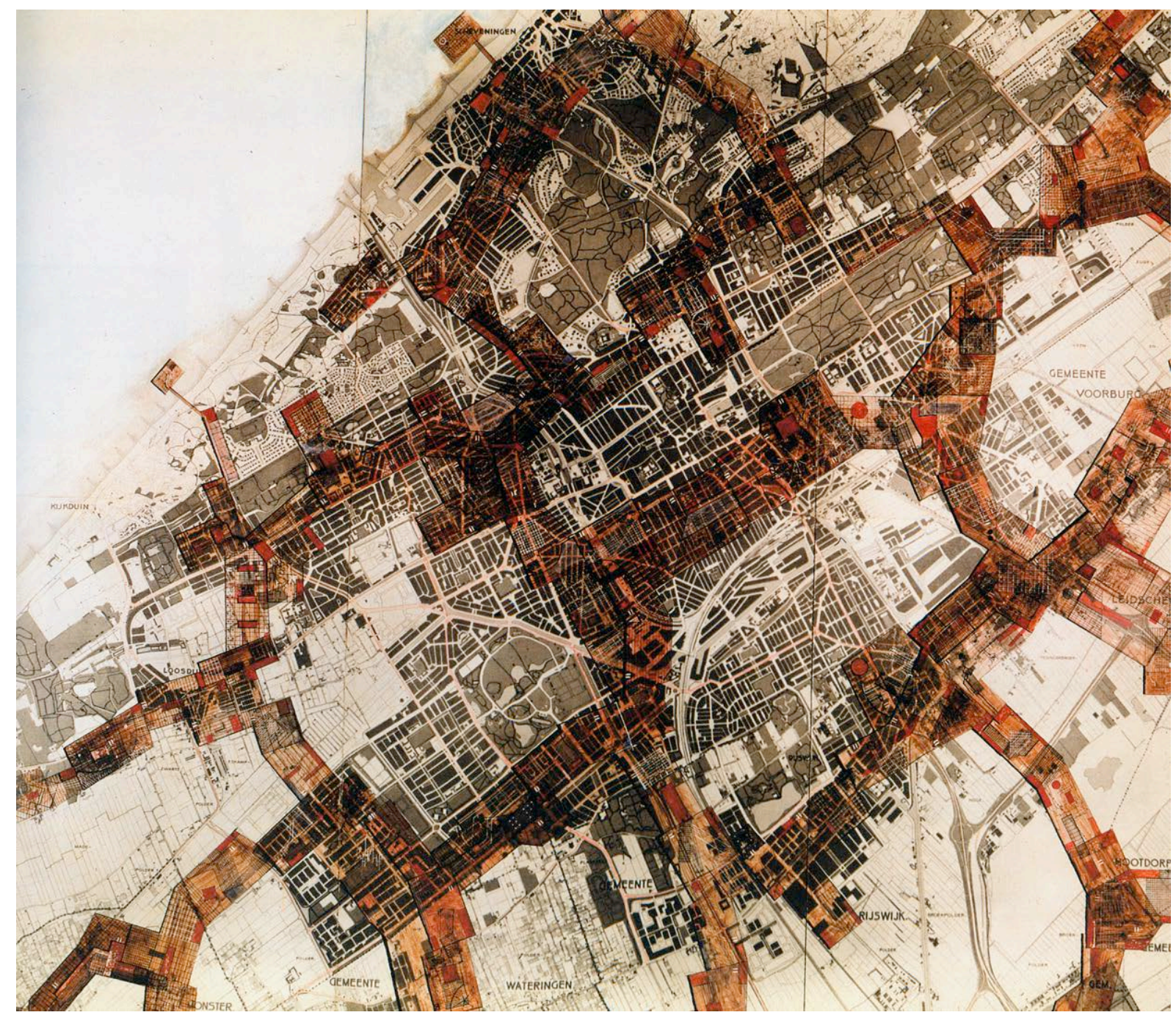

Constant Nieuwenhuys, Nova Babilônia (1959-74)

Esta dilatação dos procedimentos sintáticos da arquitetura em pleno desenvolvimento a partir da passagem do século 19 para o 20, e em plena maturação a partir dos anos 1920, traça um paralelo com a evolução histórica da escultura, o que Rosalind Krauss refere-se como campo ampliado da escultura. ${ }^{49}$ A prática do urbanismo resistia ao desenho da cidade, permitindo

\footnotetext{
${ }^{49}$ Rosalind Krauss, "Sculpture in the Expanded Field". In Hal Foster, The Anti-Aesthetic: Essays on Postmodern Culture, pp. 31-42.
} 
assim uma outra leitura crítica-poética do espaço urbano por aqueles artistas que se dedicavam a compreender o meio urbano. Tais práticas artísticas abriram um novo campo de investigação como o de se pensar as cidades, utilizando-se da arte em si como um instrumento de produção. Vistas lado a lado o Merzbau, do artista austríaco Kurt Schwitters, a Nova Babilônia, do holandês Constant Nieuwenhuys, e as Máquinas de Leitura, metaprojetos do arquiteto Daniel Libeskind ${ }^{50}$, surgem como um novo campo a ser identificado e questionado. Quais foram tais motivações e quais condições históricas que permitiram estas experimentações? Poderiam tais deslocamentos simultâneos da arquitetura via instrumento da escultura, e da escultura via instrumento da arquitetura, inseridos na nova dinâmica urbana, sugerir um campo ampliado da arquitetura, e assim influenciar não somente o destino das práticas artísticas, mas também o desenho das nossas cidades? ${ }^{51}$

II_Habitando a metrópole: da rua à praia

A rua tornou-se a habitação do flâneur; ele se sente em casa tanto entre as fachadas das casas quanto dentro das suas quatro paredes. Para ele as placas de esmalte brilhante das lojas são tão bonitas quanto as pinturas da sala burguesa. Os muros são a escrivaninha na qual ele repousa os seus cadernos de notas; as bancas de jornais são as suas bibliotecas e os terraços dos cafés são as sacadas de onde observa o seu domínio depois de um trabalho bem feito. ${ }^{52}$

Na história das vanguardas do século 20 vários avanços se sucederam dentro das práticas artísticas, criando transformações sucessivas na maneira de abordar a obra de arte, do constante re-posicionamento do artista perante à obra, o espaço e a sociedade.$^{53}$ Poderíamos considerar que tais mudanças se deram devido ao rápido desenvolvimento industrial, às

\footnotetext{
${ }^{50}$ Antes de exercitar arquitetura Libeskind foi um músico de êxito. Começou a sua atuação na profissão através da realização de desenhos, colagens, e construções efêmeras. Trabalhou antes de tudo com a imagem do texto como forma de estruturação da linguagem no espaço.

${ }^{51}$ A tentativa de compreender as relações entre arte e arquitetura se originaram em conversas com Sophia da Silva Telles nos anos 1980 e 90. Até aonde a arquitetura existe como escultura, e escultura como arquitetura? Poderíamos identificar uma prática distinta formada dos interstícios da arte e da arquitetura? A questão não se passa pelo simples campo das definições, mas tenta entender os procedimentos que transformaram e estenderam estes processos e definições. Tais diálogos, mesmo que sempre muito breves e esporádicos, motivaram inicialmente a presente pesquisa. Em 1993, em colaboração com o professor Ricardo Castro, ministramos o seminário Architecture in the Expanded Field (McGill University, Montreal), uma das primeiras tentativas estruturadas para abordar este tema.

${ }^{52}$ Walter Benjamin, Charles Baudelaire. London: Verso, 1997, p 37.

${ }^{53}$ Poderíamos considerar o desaparecimento da base na escultura, e a ruptura dos limites do quadro na pintura exemplos clássicos que demonstram estas transformações radicais.
} 
transformações tecnológicas radicais, e aos processos migratórios resultantes do amadurecimento capitalista e da consequente concentração de capital. Os processos políticos, incluindo duas guerras mundiais, promoveram em parte tais processos. Também pode-se observar que a estruturação da produção artística através da comercialização e institucionalização da obra de arte por publicações, galerias e museus rendeu, respectivamente, uma nova escala para a circulação de obras e idéias. O mundo artístico no seu contexto de produção, circulação e divulgação ascendeu a um novo patamar onde novas atividades se desenvolveram aceleradamente, como a do crítico, do historiador de arte e do curador, mencionando alguns dos exemplos mais evidentes. Tais novos mecanismos de suporte da produção artística criaram um palco favorável para o consumo da arte produzindo audiências cada vez maiores, e intensificando a comunicação de idéias nos meios artísticos, entre artistas e galeristas, historiadores, críticos, e pessoal de museu. Uma nova geografia urbana estabeleceu-se, produzindo centros como Paris ou Nova York, com a movimentação de artistas entres estes centros ou de locais de menor influência para estes centros. Porém, além das condições acima apresentadas, foi o crescimento das cidades em si, e a nova escala metropolitana, com a consequente concentração massiva do valor cultural/capital, que mais favoreceram tais transformações nas práticas artísticas. Este crescimento e consequente transformação da escala urbana patrocinaram também o congestionamento, potencializando a praia como um novo território de ocupação, como escape espacial, social e psicológico.

A densidade metropolitana junto com a concentração de capital geraram novas oportunidades empreendedoras e uma nova classe de consumo. O desenvolvimento industrial permitiu a utilização de novas técnicas de construção, mais predominantemente as estruturas metálicas, que permitiam a criação de espaços públicos internos na escala urbana, na escala da rua, com coberturas em vidro e luz zenital, bem como a criação de locais de estoque dentro das lojas, o que preconizou o aparecimento das lojas de departamento. A cidade respondeu com novas tipologias arquitetônicas, mais notadamente as galerias (Paris e Milão), que consolidaram esta nova paisagem urbana. A iluminação das vias públicas permitiu uma nova relação com o espaço, trazendo maior segurança por um tempo mais longo. ${ }^{54} \mathrm{O}$ crescimento

\footnotetext{
54 “Mas quando começou a escurecer a multidão logo aumentou, e tão logo as lâmpadas se iluminaram em toda sua potência, duas ondas densas de gente passavam pela porta [do café]. Nunca havia experimentado tal coisa num começo de anoitecer, e o tumultuado mar de cabeças inundaramme numa deliciosa emoção nova. Desisti de todas as coisas que residiam dentro do hotel e me absorvi pela cena a qual contemplava." Edgar Allan Poe, O Homem na Multidão, citado em Walter Benjamin,
} 
da cidade, com a reprodução industrial de textos e imagens provocou o início do fenômeno da cultura de massa. Uma série de camadas visuais qualificavam o espaço urbano, agora com maior número de pedestres, vitrines, pôsteres, e placas de todos os tipos. ${ }^{55} \mathrm{~A}$ partir do momento em que foi trazida para este contexto, a obra de arte se tornou, talvez pela primeira vez, não só objeto de consumo intensificado, mas também material promocional de consumo: a arte como propaganda. Esta nova paisagem visual, o que Walter Benjamin chama de fantasias desejadas ${ }^{56}$, influenciou significantemente o inconsciente coletivo.

A ampliação destes espaços internos urbanos permitiu o ajuntamento das massas em uma condição controlada pela primeira vez na história das cidades: o conforto térmico e ambiental permitiu que uma maior multidão interagisse no espaço urbano, gerando assim um urbanismo interior. Urbanismo interior refere-se a arquiteturas que correspondem à ideia de um espaço público, mas numa condição controlada e protegida. Originalmente podemos classificar as galerias européias como os primeiros urbanismos interiores. A presença de uma superfície expansiva, apresentando uma flexibilidade programática como o deck do SESC Pompéia, o térreo do Copan, ou a Marquise do Ibirapuera podem ser considerados também urbanismos interiores, e além desta qualidade urbana controlada também se relacionam ao conceito praia urbana interior.

Havia um motivo maior que atraía um maior número de frequentadores para tais centros: o que não se podia adquirir podia-se ao menos desejar, e desejar pelos olhos, o que custava somente o esforço de se deslocar para tais centros de desejos e se enveredar neste ambiente comunicativo. O conhecido flâneur, que Benjamin (via Baudelaire) tão bem identificou, não era o indivíduo que se deslocava para tais ambientes urbanos com um intuito objetivo de comprar, sociabilizar, trabalhar, ou observar, mas sim aquele que se deslocava para perder-se no espaço urbano, e consequentemente perder-se no próprio inconsciente. A figura do flâneur surgiu neste ambiente propenso à compactação visual e de novas relações humanas, entre indivíduos, e entre indivíduos e a arquitetura, conexões intensificadas com o espaço urbano. Havia então muito mais motivos - físicos, visuais, perceptivos - para se perder na cidade e entre as multidões. A figura do artista flâneur surge como um modelo

\footnotetext{
“Paris, Capital of the Nineteenth Century". Apud Neil Leach, Rethinking Architecture: A Reader in Cultural Theory, London: Routledge, 1997, pp. 33-40.

${ }^{55}$ Este processo se apresenta contínuo até os dias de hoje. Podemos estabelecer um paralelo entre as galerias parisienses como concentradores da cultura de massa e a internet como concentradora dos processos globalizantes atuais.

${ }^{56}$ Idem, p. 37.
} 
paralelo à prática do ateliê, pois o artista se viu convidado a retirar-se do próprio espaço de trabalho, o ateliê, onde havia controle total da obra. Agora, atraído pelas paisagens de desejo que a metrópole oferecia, saía de casa, e problematizava o próprio processo criativo, antes internalizado física e psicologicamente, desestabilizando assim a estrutura fechada na qual anteriormente atuava.

O desejo, agora encontrado no espaço público, provocou um movimento de dentro pra fora no processo artístico, quando o artista começou a se relacionar com o espaço exterior, interpondo-se também na nova realidade de troca, num ambiente onde o fenômeno da cultura de massa começava a tomar forma. Neste momento Baudelaire delineava a base de uma nova atitude em relação à cidade e à obra de arte a partir da sua própria relação com a nova cidade, a metrópole. Baudelaire perambulava no espaço da metrópole como um anônimo, mas mais do que isso, como um anônimo que se distancia da multidão, que, além de se perder no seu meio, transforma-se no espectador inconsciente, como se a cidade fosse um território somente de sonhos e desejos. A intensificação da informação, especialmente da informação visual, cria uma nova paisagem urbana permitindo este novo estado de consciência: de proximidade física, mas de distanciamento mental; condição necessária para o poeta flâneur. A concentração de informação e a sua distribuição favoreceu também o investimento de trocas entre idéias vanguardistas, incluindo uma observação mais meticulosa dentre as disciplinas: mais gente informada e interessada pela produção do outro, iniciando assim um processo de rompimento entre as fronteiras disciplinares. 


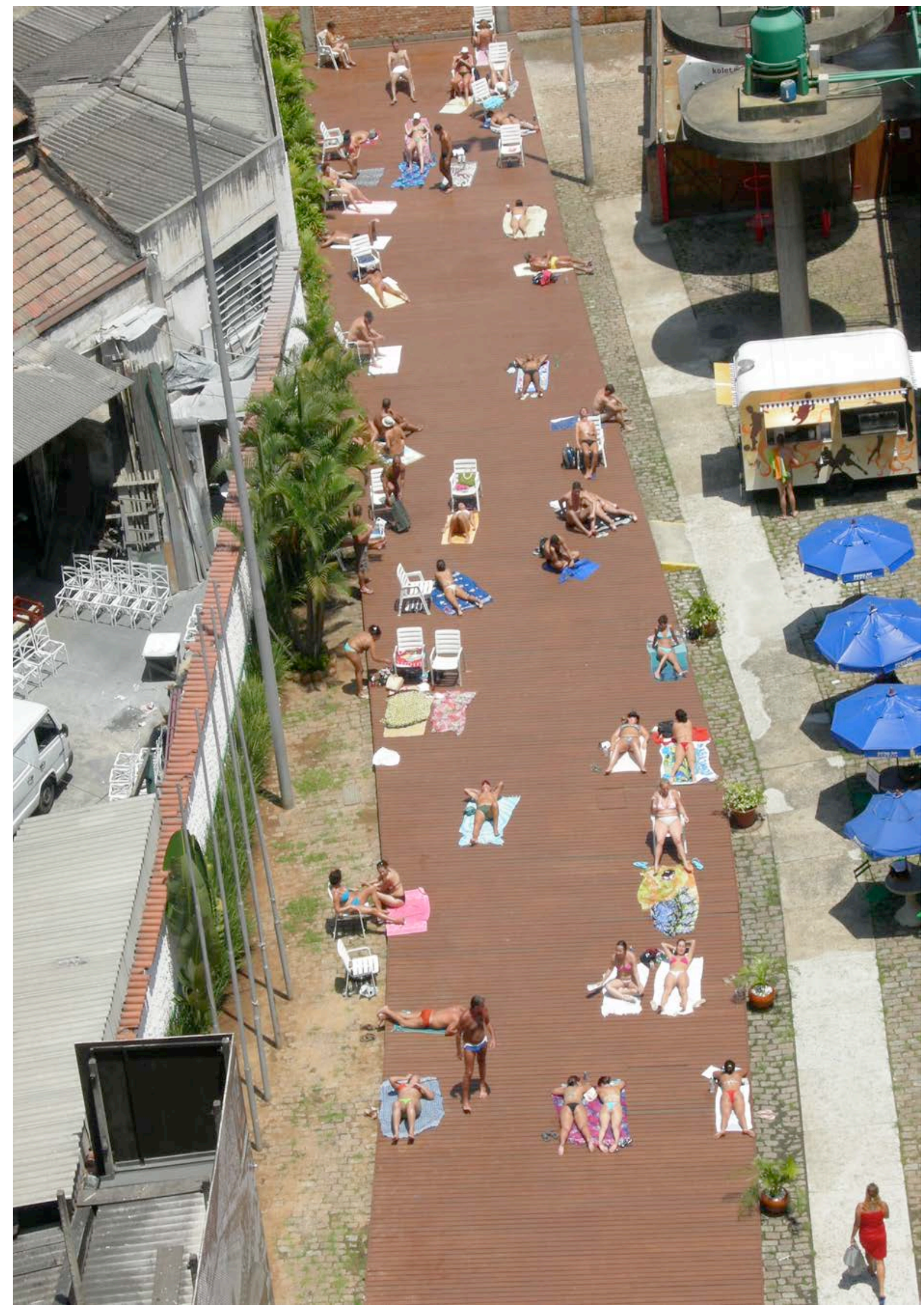

Lina Bo Bardi, SESC Pompéia, São Paulo (1982) 
Foram estas transformações na cidade e na vida urbana que impulsionaram o artista flâneur a utilizar recursos ainda não cogitados em relação à obra de arte, não mais se limitando aos recursos tradicionais do livro (ou da biblioteca) do quadro ou do objeto autônomo da escultura (ou do ateliê). Foi assim iniciado um outro processo histórico com Gérard de Nerval, possivelmente o primeiro artista flâneur, que, perambulando pelo Palais Royal nos idos dos 1840, utilizava de uma estratégia de deslocamento para assim transformála em material poético. ${ }^{57}$ Podia-se, entretanto, imaginar de Nerval (tão como Baudelaire) habitando a cidade como um todo, e não somente os locais onde as multidões encontravam-se com o consumismo. A flânerie se sucedia então por uma série de movimentos do artista dentro da cidade que passava do espaço doméstico do estúdio aos espaços inteiramente públicos, inconscientemente identificando esta passagem, do espaço individualizado do artista ao espaço público. Antes, era só a obra que circulava (galerias, livros, museus, bibliotecas, etc.) Agora, além do artista em si sair do ambiente tradicional de criação, o espaço público urbano se apresenta como o material da obra, e até mesmo como a obra em si. ${ }^{58}$ Além do espaço metropolitano, haviam os espaços de deslocamento mais alargados, que significaram tanto para a evolução das artes do século 20. Movimentos político-culturais, e diferentes fatores econômicos provocaram longos deslocamentos entre metrópoles, especialmente entre Paris e Nova York, possibilitados pelas novas tecnologias de transporte aéreo ou terrestre, facilitando a contaminação social, criativa e intelectual para tantos artistas. Estes deslocamentos seriam reconhecidos como um novo estado mental, associados à nova energia da metrópole. $\mathrm{O}$ artista agora habitava definitivamente a grande cidade.

Num segundo momento do processo metropolitano, onde o congestionamento urbano apresentou-se como problema, como um estanque da cidade, os sonhos e desejos se transferiram do flâneur para a praia, preconizando a identificação da praia como território de prazer. As primeiras histórias da habitação da praia surgiram como uma progressão natural da experiência da rua, forçadas exatamente pela pressão urbana que crescia gradativamente.

\footnotetext{
57 James Trainor, "Walking the Walk: the Artist as Flâneur". Winnipeg: Border Crossings Magazine, no. 88, 2003, pp. 82-92.

58 “A cidade favorece a arte, é a própria arte, disse Lewis Munford. Portanto ela não é apenas, como outros depois dele explicitaram, um invólucro ou uma concentração de produtos artísticos, mas um produto artístico ela mesma." Giulio Carlo Argan, História da arte como história da cidade, p. 73.
} 
III_ Do espaço da casa para o espaço da rua

A superfície das coisas dá prazer, a sua interioridade produz a vida. ${ }^{59}$

Em 1926, época em que já vivia em Paris, Piet Mondrian escreveu o texto Home-Street-City ${ }^{60}$, no qual sintetiza os paradigmas do Neo-Plasticismo e sinaliza a cidade como ambiente ideal para o equilíbrio entre os homens, num clima aberto de união. Esta visão ideal da cidade aparece em associação com o próprio programa estético de Mondrian, no qual procurava, a partir de composições organizadas por linhas, planos e cores primárias, um espaço pictórico ideal. Mesmo sendo um defensor árduo do novo individualismo que a metrópole possibilitava, Mondrian favorecia um pleno coletivismo baseado num sentimento cívico e a possível busca por um espaço urbano organizado pelos pressupostos do Neo-Plasticismo. Em Home-Street-City Mondrian traça as relações entre o Neo-Plasticismo e a experiência urbana, resultando em um questionamento sobre a estética a partir do ponto de vista da cidade.

O mérito maior de Mondrian foi a localização de uma continuidade entre o dentro e o fora, entre o espaço doméstico e o espaço público, dando como possível uma coerência integral entre os espaços, ou o que ele chamou de "ação recíproca de opostos, para dentro, para fora (espírito e natureza)" ${ }^{61}$ Neste caso Mondrian via a casa como parte de um todo, um elemento estrutural da cidade. Mondrian propunha uma condição espacial sem divisões definitivas, mas que ao invés expunha uma possível continuidade (espacial, social e perceptiva), contrastando com a dialética dentro e fora de Bachelard, onde estas duas distintas condições espaciais são sempre apresentadas como opostos, como sim e não. ${ }^{62}$

A dicotomia apresentada pelas características maiores destes distintos conjuntos de espaços, a casa e a cidade, tendo a casa como um espaço em constante mutação, alterado diariamente por seus habitantes, apresentava-se em contraste evidente com caráter permanente, imanente da rua. Esta permanência da rua que Mondrian menciona reporta-se à

\footnotetext{
${ }^{59}$ Piet Mondrian citado em Michel Seuphor, Abstract Painting, New York: Dell Publishing Co., 1964, p. 11, tradução nossa.

${ }^{60}$ Publicado no primeiro número da revista i10, em janeiro de 1927 sob o título "Neo-Plasticisme: De woning-de straat-de stad" (Casa-Rua-Cidade). H. Holtzman, e M. S. James, The New Art-The New Life: The Collected Writings of Piet Mondrian, pp. 205-212.

${ }^{61}$ Idem, "The New Plastic in Painting", p. 47.

62 “Dentro e fora formam uma divisão dialética, uma óbvia geometria que nos cega tão logo começamos a lidar com circunstâncias metafóricas." In Gaston Bachelard, The Poetics of Space, p. 211.
} 
descrição do urbanismo barroco de Ricardo Marques de Azevedo: "uma totalidade acabada, na qual as relações estão meditadamente controladas, subordinando-se à unidade." ${ }^{63} \mathrm{~A}$ riqueza dos espaços interiores se dá pelas possibilidades individuais e às dinâmicas cotidianas de mudança, gerando um espaço ao mesmo tempo menos controlado e mais conectado às identidades pessoais, diferentemente da rua, que se apresenta como a providente soberania do sistema de controle urbano. ${ }^{64} \mathrm{O}$ ideal mondriano era encontrar este equilíbrio entre os espaços interiores e os espaços exteriores da experiência urbana, e aí apontava tal integralidade como a solução dos problemas da cidade grande, substituindo o lírico pelo puramente plástico. Tal simplismo pode ser considerado como uma estetização exacerbada da complexidade dos espaços e experiências da rua e todas as suas relações e ramificações, sugerindo uma solução quase que exclusivamente formal, originada na composição do quadro, e agora transposta para a escala do planejamento urbano. Fica pelo menos transparente que o artista do início do século 20 observa atentamente o fenômeno espacial para além do plano de representação, abrindo-se agora para o sentido do próprio corpo (via percepção de deslocamentos individuais) e o espaço urbano como locus da experiência física, cultural e estética.

A proximidade de Mondrian com o conceito de arquitetura como plástica desenvolveu além das observações e relacionamentos que estabelecia com os espaços inerentes à sua própria pintura. A amizade com Van Doesburg ${ }^{65}$, e o conhecimento que tinha do trabalho de Ritveldt, De Stijl, e seus outros colegas holandeses o levaram a refletir sobre as possibilidades concretas da arquitetura. Em Londres foi persuadido a deixar a Europa para ir a Nova York depois da invasão nazista de 1940. Foi em Nova York que abriram-se novas possibilidades de experimentações sobre as relações entre os espaços compositivos da tela com a experiência espacial urbana. Dois momentos marcantes se sobressaíram neste processo de novas descobertas: as pinturas Broadway Boogie-Woogie e Victory Boggie-Woogie; e o projeto ambiental do seu último estúdio, na rua 59.

Em ambos trabalhos pictóricos Mondrian simula o espaço da rua, ramificando planos e linhas a ponto de aproximar-se do espírito da rua Broadway, como os seus painéis luminosos, e até mesmo com o traçado e a dinâmica de Manhattan. Em Victory Boggie-

\footnotetext{
${ }^{63}$ Ricardo Azevedo, op. cit., p. 9.

${ }^{64}$ Idem, p. 9.

${ }^{65}$ Interrompida depois que escreveu Home-Street-City, pois Van Doesburg era defensor da idéia de separação entre representação e o espaço por acreditar que a arte é oposta à natureza e não convinha desejar portanto uma integralidade, a qual Mondrian defendia.
} 
Woogie, sua derradeira pintura, ele executa uma rotação de $45^{\circ}$, intensificando ainda mais as relações com os movimentos da cidade, neste caso mais específico, com Times Square, a poucos quarteirões do seu estúdio. A Broadway é uma das únicas vias de Manhattan que, inclinada, sai da grade reguladora da estrutura urbana da cidade, e quando chega em Times Square, entre as ruas 42 e 44 a compressão normal entre os quarteirões se expande, pois no interstício rua/quarteirão não existe superfície suficiente para uma ocupação normal de um bloco. Esta inusitada espacialidade urbana, expandida pela intersecção diferenciada na grade regular cria um evento urbano de rara energia. Podemos até dizer que o sucesso de Times Square se dá por esta inesperada expansão no meio da densa grelha da cidade. Victory BoggieWoogie é a pintura mais aglomerada da sua fase geométrica-abstrata, e, mais densa e movimentada que Broadway Boogie-Woogie, foi influenciada pela recente experiência de Mondrian com a rua e com a música. ${ }^{66}$

Com um gesto mais próximo e radical em relação à integralidade espacial que defende em Home-Street-City, desde o espaço mais íntimo (casa), ao mais público (rua), Mondrian realizou, durante os quatro últimos meses de vida, um projeto ambiental para o seu estúdio. Ali criou dois componentes principais: instalou planos coloridos em cartão compostos ao longo das paredes; e desenhou e fabricou todo o mobiliário, muitos dos elementos construídos com caixotes de frutas encontrados na rua.

Aqui encontramos um Mondrian mais próximo daquele que se propôs a encontrar a integralidade entre os espaços urbanos de Home-Street-City, escrito dezenove anos anteriores a este episódio final. Com estes últimos atos criadores ele deixou uma herança significativa na história dos processos estéticos, de que, na verdade, é possível considerar a plenitude de espaços e representações numa mesma experiência estética, exatamente no interior do qual habitamos. A arte se mostra instrumental na absorção perceptiva dos espaços, e mais que isso, sintoniza-se com a vida cotidiana, ou como ele mesmo concluiu:

\footnotetext{
${ }^{66}$ Haja vista o interesse de Mondrian pelo jazz (Jazz and Neo-Plasticism, 1927). Boogie-woogie é uma forma de blues caracterizada por uma linha de baixo e ritmos propulsivos de oito notas. Quando Mondrian chegou em Nova York em 1940, o boogie-woogie passava por uma renascença comercial e foi adotado por grupos de jazz e big bands. Mondrian preferia a versão original para piano e frequentava o Café Society Downtown para ouvir o trio Boogie-Woogie, com os pianistas Meade "Lux" Lewis, Pete Johnson e Albert Ammons. Mondrian contou para Sidney Janis, seu galerista, que o seu uso de cores desde que chegou em New York dava ao trabalho "mais boogie-woogie". Disponível em: <http://www.artmuseums.harvard.edu/mondrian/glossary.html>. Acessado em: 14 de julho de 2010.
} 


\begin{abstract}
... a casa não pode mais estar selada, fechada, separada; nem pode a rua.
Enquanto preenchem funções diferentes, a casa e a rua devem formar uma unidade. Para obtê-la temos que parar de olhar para a casa como uma caixa, ou um vazio. A idéia de "lar" - "lar-doce-lar" - deve ser destruída ao mesmo tempo que a idéia convencional de rua. A casa e a rua devem ser vistas como a cidade, numa unidade formada por planos compostos neutralizando a oposição que destrói toda exclusividade. 0 mesmo princípio deve governar o interior da casa, que não pode mais ser um conglomerado de cômodos - quatro paredes com buracos para portas e janelas - mas uma construção de planos em cores ou planos incolores unificados com mobiliário e objetos domésticos, que não serão nada em si mas partes de um todo. E o homem? Nada em si, mas se tornará parte deste todo; e perdendo o mesquinho e patético orgulho individual, ele será feliz no Éden que criou! ${ }^{67}$
\end{abstract}

Tanto quanto às instalações interiores de Mondrian, quanto às experimentações pictóricas de Broadway Boogie-Woogie e Victory Boggie-Woogie indicam não só a visão e o desejo de conquistar artisticamente o espaço publico, agora como uma continuidade indiscutível do espaço doméstico da casa, mas sugerem uma mudança transformadora da superfície urbana através da programação mais dinâmica desta mesma superfície. Ao compor Broadway Boogie-Woogie e Victory Boggie-Woogie Mondrian não se atem ao mapa de Manhattan em si, mas reinventa-o, imaginando uma nova vida tanto em casa como na cidade. Esta transformação sugere no campo da representação uma nova maneira de alterar a maneira como habitamos a casa e a cidade, propondo um novo programa de maneira inequívoca.

Poderíamos assim imaginar o destino artístico de Mondrian diretamente para a rua, um precursor incubado da arte pública. Então por analogia consideramos a passagem da tela para a rua paralela ao processo de conscientização da praia como superfície. A superfície tanto da tela quanto da praia não é inócua ou simplesmente acidental mas ela recebe as expressões de um povo da mesma maneira que na tela residem as expressões do artista. Esta energia também não se limita ao campo da representação mas assume a escala direta da vida. Da mesma maneira que Time Square "penetra" na tela de Mondrian, a vida penetra na praia cotidianamente. Arte pública emergiu para negociar as diferenças entre a representação e a realidade da vida pela sua inesperada presença no espaço público contribuindo igualmente com uma propriedade crítica ao urbano: duas superfícies aparentemente distintas mas com enorme carga energética e de significados.

\footnotetext{
${ }^{67}$ Piet Mondrian, In H. Holtzman, e M. S. James, The New Art-The New Life: The Collected Writings of Piet Mondrian, p. 212.
} 


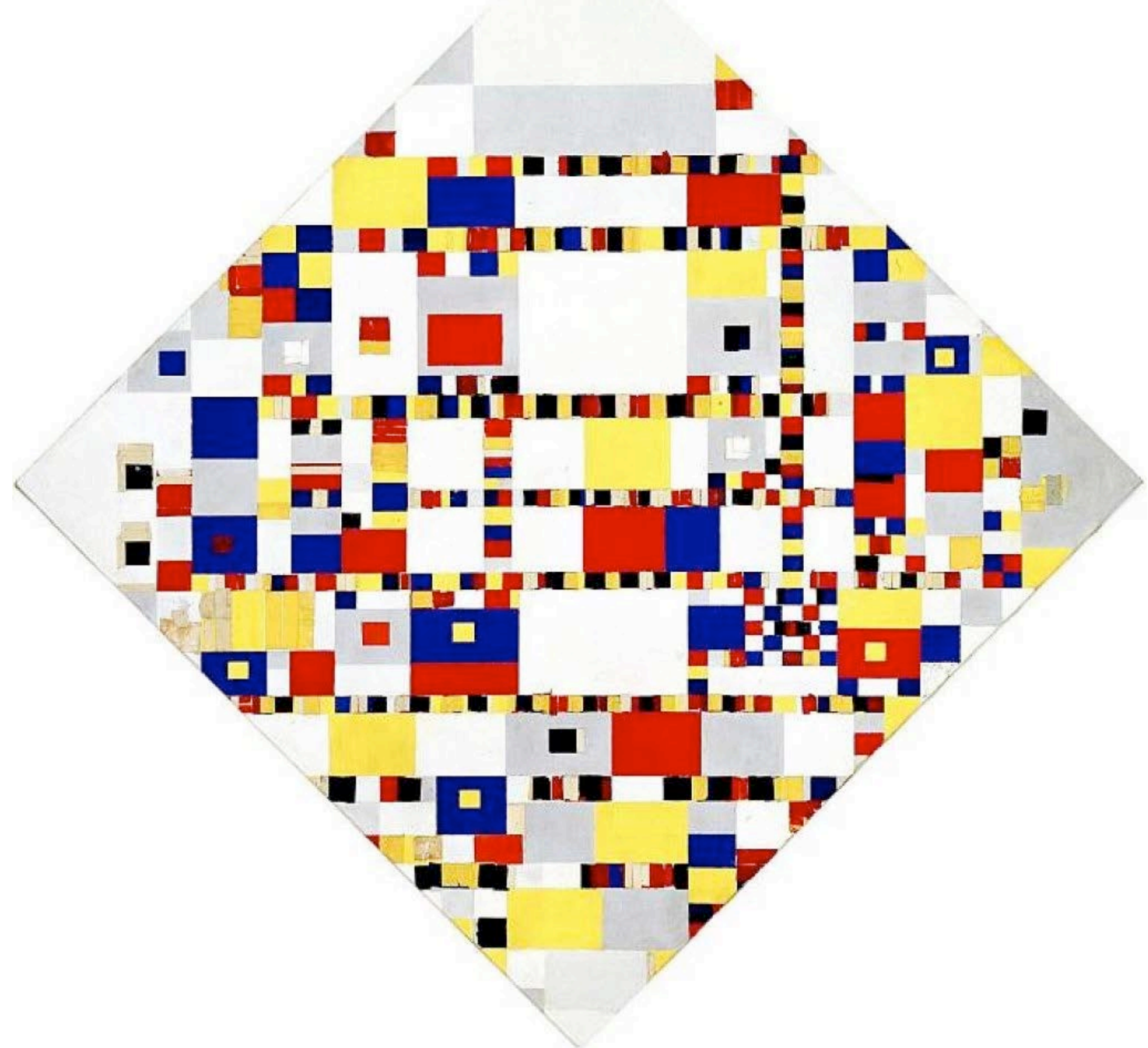

Piet Mondrian, Victory Boggie-Woogie (1944)

IV_Rompimento interior

O que ficou como grande desafio estético para Mondrian virou realização para Marcel

Duchamp. Migrantes europeus, contemporâneos, vivendo em Nova York, tiveram trajetórias distintas mesmo que interessando-se por questões análogas. A hesitação mondriana, reduzida a elementos formais colocados no espaço, em Duchamp transforma-se no espaço mítico duchampiano, como observamos em Door: rue Larrey, trabalho realizado no mesmo ano em que Mondrian publicou Home-Street-City (1927). Aqui, Duchamp, ávido em explorar e expandir o conceito épico do readymade, transforma, com a ajuda de um carpinteiro, uma das 
portas do seu apartamento em Paris. Por definição uma porta divide dois ambientes, às vezes separando dentro e fora, ou programas distintos. Aqui a porta do estúdio da rua Larrey é transformada para dar acesso a duas entradas simultâneas (banheiro e quarto). Na única imagem conhecida deste trabalho sugere que tal resposta não corresponde à uma necessidade funcional pois a porta pode se fechar para um ambiente, mas porque então deixar um espaço aberto para os outros dois restantes? Uma porta de acesso a três ambientes? E quando a porta encontra-se aberta, nunca está totalmente aberta (pois o totalmente aberto para um dos cômodos significaria fechado para outro), mas encostada, e então entreaberta para os três cômodos.

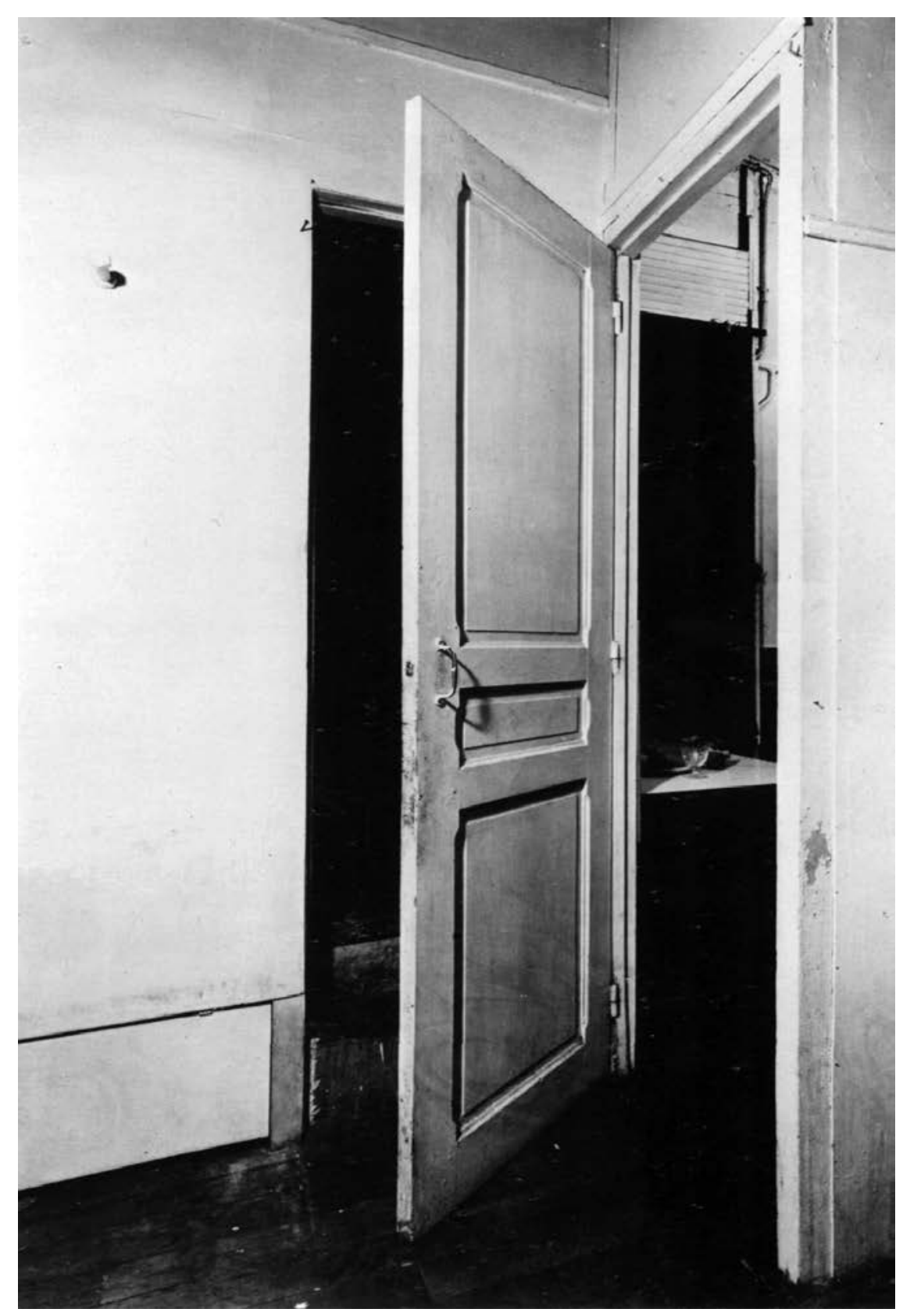

Marcel Duchamp, Door: rue Larrey (1927) 
Duchamp consideraria tal projeto um readymade modificado (sendo a porta o readymade, e a alteração pelo carpinteiro a modificação). Aqui Duchamp altera a definição de porta pela própria reinvenção da sua função original (fechar ou abrir, dar acesso, etc), pois não mais necessariamente executa somente as suas tarefas originais. ${ }^{68} \mathrm{~A}$ partir deste ato, a porta, ainda que parte da estrutura original do apartamento, da sua arquitetura, assume um novo significado pela nova vocação, agora também existindo como obra de arte. O que fundamentalmente separa o ato mondriano do duchampiano é que Duchamp reconhece imediatamente o valor e o potencial estético em um objeto incorporado à arquitetura enquanto Mondrian ainda adiciona arte ao ambiente. Duchamp não vê necessidade em acrescentar arte ao ambiente, mas reconhece que o ambiente apresenta-se como a obra em si. No entanto, o que resta de significativo nestes procedimentos é a consolidação da relação entre o artista e a cidade, entre o artista e o seu espaço doméstico íntimo.

Poderíamos qualificar dois tipos de artistas: revisionistas e renovadores. Os primeiros resguardam-se por trás do conforto (conflito?) historicista e residem num estado contínuo de argumentação formal (Mondrian). Os renovadores são aqueles que sempre buscam uma ruptura dos processos históricos e se capacitam em executá-la pois são hábeis em acionar percursos de rompimentos no interior dos próprios atos criadores (Duchamp). Entre revisionistas e renovadores existem aqueles que só procuram o melhor, aquilo que vai além das expectativas, uma outra visão de mundo, evolucionária, melhor no sentido de modernidade, a qual transmitirá não só a compreensão de um sentido presente, mas que proporá uma mudança a partir de tal sentido abrindo as comportas para mais descobertas. Jurgen Habermas também identifica Baudelaire como o inaugurador do espírito e da estética moderna, e, atentando para uma definição desta mesma atitude moderna ${ }^{69}$, descrita acima através de duas proposições distintas mas complementares, avança a questão:

A modernidade estética é caracterizada por atitudes que acham um foco em comum numa mudança de consciência do tempo. Nestes períodos a consciência se manifesta

\footnotetext{
${ }^{68}$ Mais tarde, nos anos 1960, Joseph Kosuth desdobra a Porta de Duchamp em uma outra obra, Uma e Três Cadeiras (One and Three Chairs, 1965), na qual apresenta três representações diferentes, lado a lado, para o mesmo objeto: uma definição de dicionário impressa, uma foto da cadeira, e a cadeira em si, parte da série Art as Idea as Idea. Separadas tais representações são apenas definições convencionais para o objeto. Justapostas elas criaram uma das mais reconhecidas obras da arte conceitual.

69 Jurgen Habermas, “Modernity - An Incomplete Project”. In Hal Foster, The Anti-Aesthetic: Essays on Postmodern Culture, Seattle: Bay Press, 1983, pp. 3-15.
} 
através de metáforas da vanguarda e da avant-garde. Por vanguarda compreende-se como aquela que invade territórios desconhecidos, expondo-se aos riscos repentinos, encontros chocantes, conquistando um futuro ainda não ocupado. A vanguarda deve encontrar uma direção numa paisagem onde ninguém aparenta ter-se aventurado ainda. ${ }^{70}$

Se, há mais de meio século atrás, Gérard de Nerval e Charles Baudelaire introduziram a atitude moderna através da imagem do artista flâneur, que se entrega para a cidade, consome e é consumido por ela, Piet Mondrian e Marcel Duchamp ajudaram a fortalecer, junto com muitos outros artistas do século 20, a ruptura interdisciplinar entre arte e arquitetura e se tornaram precursores no processo de engajamento urbano.

A visão do artista contempla o objeto tradicional da arte, e busca uma nova vocação, pois aquilo que se apresenta defronte dele não capacita a sua ambição estética, vinculada a uma problemática permanente. $\mathrm{O}$ artista não se preocupa com a classificação simplista da obra de arte (o que é / o que não é), com o locus da obra (onde se encontra / onde deveria estar), tarefa esta que cabe ao crítico ou ao historiador. Na busca de novas relações um novo território abre-se dentro do panorama das artes do século 20. A arquitetura se distancia das vocações técnicas e econômicas do pós-guerra, onde limitava-se à reconstrução e massificação através da produção industrializada; e a arte escapa dos calabouços institucionais e dos circuitos fechados das galerias e dos museus.

Quando estes dois mundos se expandem, eles se encontram no espaço comum da metrópole, e inevitavelmente novas formas são geradas a partir da presença do artista na cidade, a partir destes encontros inevitáveis, e das sugestões de que a abstração, gerada agora pelo novo inconsciente subjetivo/coletivo, é o condutor da nova arte. ${ }^{71}$ Enquanto estes processos de transformação se sucediam objetivamente no interior do processo de criação de Mondrian e Duchamp um processo paralelo se davam inconscientemente na psicologia daqueles que habitavam a metrópole. Esta força interna que empurrava o indivíduo da casa para o espaço público ao mesmo tempo transformava a maneira doméstica de viver diminuindo as barreiras entre o dentro e o fora, criando uma continuidade de vida entre o universo doméstico e o público. Estas forças dinâmicas, em uma maneira diferenciada de viver, promoveram rapidamente o acesso à praia urbana, agora claramente compreendida como extensão natural da casa.

\footnotetext{
${ }^{70}$ Idem, p. 5.

${ }^{71}$ Ver capítulo 2 “A Metrópole”, em Ricardo Azevedo, Metrópole: Abstração, pp. 9-18.
} 


\title{
5_ SITUACIONISMOS E A ATITUDE "PÚBLICA"
}

\section{I_Situacionismo como resistência}

No processo de transformação das praticas artísticas em Mondrian e Duchamp e no reconhecimento da casa e da rua como condições primordiais no processo de desconstrução do espaço artistas começam a utilizar de procedimentos que arquitetos tradicionalmente usam, e arquitetos se voltam cada vez mais para atitudes observadas no trabalho de artistas. John Hejduk diferencia tal atitude pelo valor inverso que a arquitetura injeta nestes processos, coexistindo entre dois mundos agora antagônicos, o da imaginação e o da construção:

\begin{abstract}
... como se sabe, o papel tradicional do arquiteto tem sido prover o que outros podem prover mais eficientemente e no ponto. 0 que me interessa não é o que os arquitetos podem prover que outros também podem (um tipo de paralelismo), mas aquilo que só o arquiteto pode prover. Acredito que agora, mais do que nunca, só o arquiteto pode prover aquilo que afeta o espírito. Espírito é uma palavra enorme e amórfica, mas nada menos do que isso, qualquer tentativa ou estudo ou investigação que não se mova para este ponto central - iria dizer irrelevante - simplesmente não é arquitetura. $^{72}$
\end{abstract}

Hedjuk, como seu trabalho tão bem testifica, busca para a arquitetura uma nova ordem de valores, extintos por força do supercapitalismo do pós-guerra, e recupera um sentido, centrado no espírito, que sempre foi a motriz da existência da arquitetura. O que Hedjuk deixa claro é que a arquitetura sempre foi parte da família das artes e não da indústria da construção, e como tal, a questão da arquitetura sempre foi, antes de tudo, poética. Tais redefinições, acompanhadas com as transformações sociais da época, liberaram uma nova gama de possibilidades, bem recebidas por artistas nos anos 1960 e 70, resultado do confronto intelecto-político emanado nos anos 1950.

Os movimentos feminista, gay, estudantil e black power, por um lado; o pósestruturalismo, representado especialmente por Jacques Derrida e Michel Foucault, por outro lado, desestabilizaram a ordem normativa e a hegemonia do pensamento ocidental criticando o estruturalismo (lógica, razão científica) que defendia a idéia da autonomia e pureza de pensamento (ou do objeto de arte). O pós-estruturalismo questionou tal posição inserindo a idéia de que quaisquer processos (filosófico, artístico, etc) são resultados de complexas

\footnotetext{
72 John Hedjuk, apud J. Brand e H. Janselijn, Architectuur en Verbeelding (Voorwoord), p. 5
} 
organizações (sistemas de conhecimento) e de outros contextos e eventos, e têm que, necessariamente, incorporar componentes culturais sob todas as circunstâncias. Tais componentes seriam a localidade, a economia, o autor, a audiência, e a sociedade em que o evento se encontra (em geral, e em particular a localizada por causas comuns, e o indivíduo). Foucault, por exemplo, questionou as relações de poder, como eram geradas, e como eram administradas. Mais especificamente, no caso da tipologia arquitetônica, usou o panopticon como exemplo de análise para desmontar e explicar as estruturas de controle e poder. Como resultado deste processo, novas disciplinas foram criadas como a teoria cultural, e o consequente rompimento da superespecialização de disciplinas. ${ }^{73}$ Fica claro que existe sim um novo/velho âmbito a ser explorado, e mais que isso, ficou aberta a possibilidade para intercampos de procedimentos.

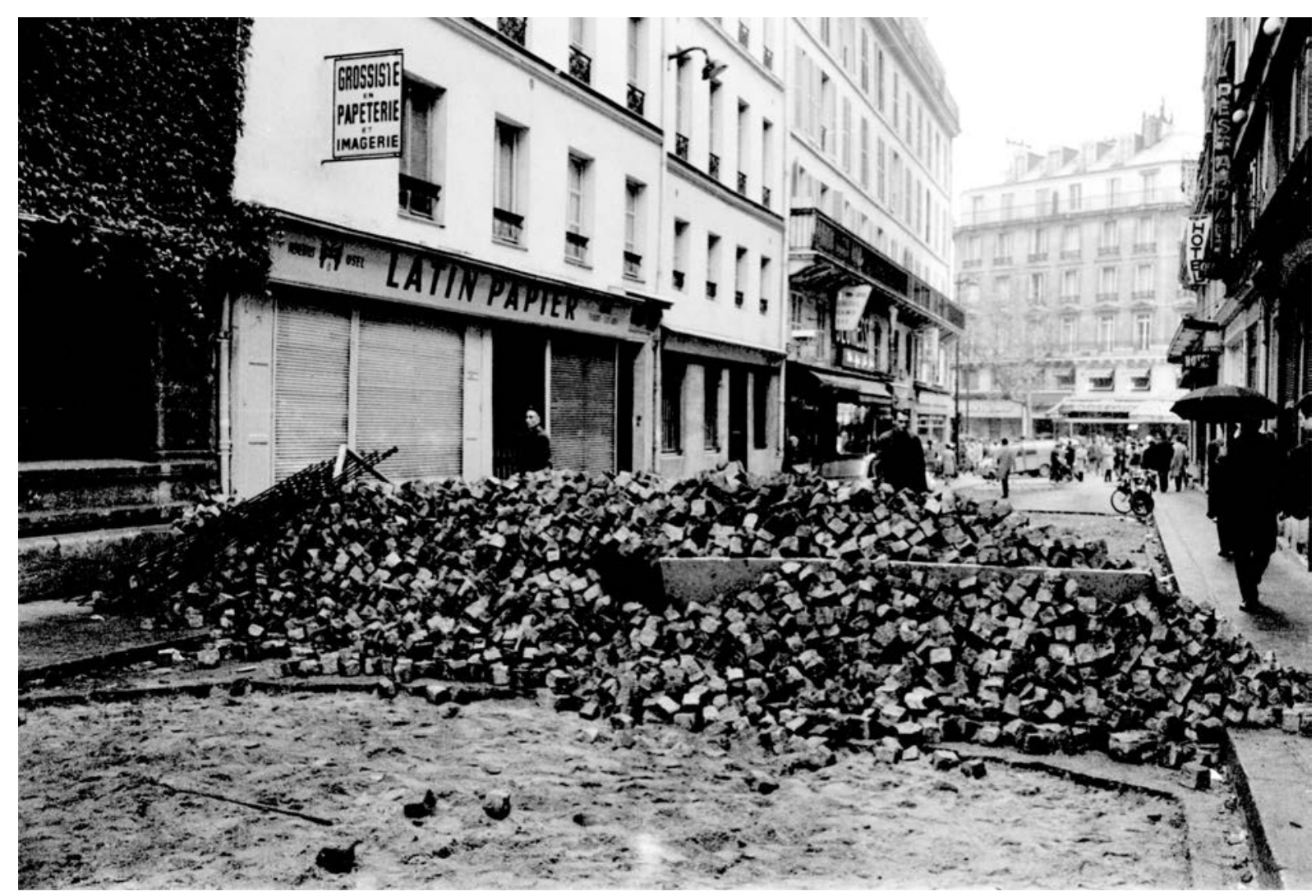

Situacionista Internacional, Sob o asfalto a praia! (maio de 1968)

\footnotetext{
73 "Nos últimos dez ou quinze anos, a enorme e proliferada criticabilidade das coisas, das instituições, das práticas e discursos; um tipo de sentimento geral de que o chão se desmoronava sob nossos pés, especialmente em lugares que nos pareciam mais familiares, mais sólidos, mais perto de nós e de nossos corpos, dos nossos próprios gestos. Mas, acompanhando este desmoronamento e a assustadora eficácia das descontínuas e específicas críticas localizadas, os fatos estavam também revelando algo... debaixo desta temática toda, através dela e mesmo no seu interior, nós temos visto o que poderia ser chamado de a insurreição dos conhecimentos subordinados." Michel Foucault, Society Must be Defended: Lectures at the Collège de France, 1975-76 (7th January 1976). London: Picador, 1983. Tr. David Macey.
} 
Se considerarmos tais inter-relações e ramificações entre arte e arquitetura, duas direções evoluíram nas práticas contemporâneas do pós-guerra, determinadas por condições espaciais que se apresentavam como indagações ao lugar tradicional da arte (o espaço da galeria; a instituição do museu). Fica claro que, através destas novas manifestações, havia uma crítica intrínseca a tais práticas, que claramente resistiam ao circuito oficial das artes. Por um lado, identificamos um tipo de ação que se dá na rua: artistas engajados no espaço urbano e gerando o trabalho neste contexto. A outra manifestação se constitui num galanteio, numa apropriação devassa dos elementos da arquitetura, transformando-os através do domínio de sua tectônica em obras de arte autônomas. Poderíamos identificar um terceiro grupo que seria o dos arquitetos, que, mesmo não abandonando as práticas tradicionais vinculadas ao escritório e ao edifício, ensaiaram experimentos que mais se assemelhavam àquilo que os artistas estavam realizando. Dentro deste grupo podemos citar Daniel Libeskind, Siah Armajani, Rem Koolhaas, Bernard Tschumi, Leon Krier, Juan Navarro Baldeweg, Andrea Branzi, dentre outros. Um quarto grupo seria o dos adeptos da Land Art, que, apesar de possuírem motivações semelhantes, deixaram a cidade para realizar os seus experimentos em territórios remotos, como no deserto. Seria então vital citar estes grupos, mais especificamente: os artistas que atuam na rua e aqueles de se utilizam da sintaxe da arquitetura. Na genealogia de tais atitudes, no reconhecimento tanto das condições históricas (Baudelaire $>$ Mondrian $>$ Duchamp $>$ Hedjuk), como da consolidação da nova esfera pública que agora apara as novas práticas, a topologia avança como elemento determinante da obra de arte e da arquitetura. Então, na transposição das práticas, da arquitetura valorizando a representação, e das artes plásticas reivindicando o espaço enquanto expressão um novo campo é descoberto. Começa assim a se formar um novo gênero de ação criadora com os seus limites dissolvidos: a gênese da matriz de praiapaisagem.

O rápido domínio internacional americano, apoiado pelo supercapitalismo resultante do pós-guerra, bem como a guerra fria e a desestabilização política dos anos 1950 provocaram reações várias no mundo inteiro. A nova reorganização política permitiu brechas de resistências na comunidade artística, entre a intelligentsia acadêmica, entre os jovens estudantes, grupos políticos minoritários, e nos grupos sociais subordinados. Um dos grupos que emergeu neste panorama foi a Situacionista Internacional, originado em 1957. Localizado inicialmente em Paris e inspirado por ideologias marxistas, teve como um dos seus principais líderes o teórico francês Guy Debord. A Situacionista Internacional tinha como regra 
principal construir situações com o intuito de provocar a esfera pública para assim causar as grandes transformações políticas e sociais que o grupo defendia. Não cabe aqui transcorrer sobre a incongruente história e a eficácia política duvidosa do $\operatorname{grupo}^{74}$, mas sim ressaltar a grande proximidade que existia entre suas posições políticas e o contexto artístico daquele momento.

Para a Situacionista Internacional a arte era um vínculo de ação prescindível pois, em espírito e técnica, associava-se construtivamente aos ideais situacionistas. O espaço urbano, apresentado na sua permanência militar através dos boulevares Haussmanianos com o seu controle reacionário, virou palco perfeito onde a resistência se expressava contra as autoridades vigentes. No famoso maio de 68, a Situacionista Internacional participou ativamente dos eventos revolucionários estudantis a ponto de ter ocupado e defendido junto com os estudantes e trabalhadores as barricadas da Sorbonne. Anos antes, Christo e JeanClaude tiveram a premonição de tais condutas de controle espacial através da "situação" Muro de baris de óleo, Cortina de ferro (1962) ${ }^{75}$ que articulou um comentário simultâneo em torno dos enlaces políticos com o território urbano e com um contexto maior das políticas internacionais. Durante oito horas Christo and Jeanne-Claude fecharam a rua Visconti com 240 barris de óleo. A barricada obstruiu a maioria do tráfego da Rive Gauche. Aqui a obra de arte torna-se ação política, e sem perturbar permanentemente a infraestrutura, torna-se situacional pela sua efemeridade e contextualização. São eventos como este que tornaram possível uma proximidade entre a SI e os movimentos de vanguarda. ${ }^{76}$ As estratégias paralelas da SI e dos artistas reivindicavam uma mesma meta, isto é, arte como revolução, e, de tempos em tempos, se localizavam exatamente no mesmo território.

\footnotetext{
${ }^{74}$ Para uma coletânea online de textos de autoria de autores situacionistas, veja o site <http://www.nothingness.org/SI>. Para a mais completa coleção de escritos situacionistas, veja Ken Knabb, Situationist International Anthology, Berkeley, Bureau of Public Secrets, 1995.

${ }^{75}$ Disponível em: <http://www.christojeanneclaude.net/fe.html>. Acessado em: 23 de julho de 2011.

${ }^{76} \mathrm{~A}$ origem da Internacional Situacionista foi na verdade localizada em grupos de vanguarda dos anos 1940 como o movimento letrista de Paris (Isidore Isou, Gabriel Pomerand), o Grupo Cobra (Asger Jorn), os surrealistas de Bruxelas (René Magritte, Paul Bourgignie) e o Grupo Experimental Holandês (Karel Appel, Corneille e Constant Nieuwenhuys).
} 


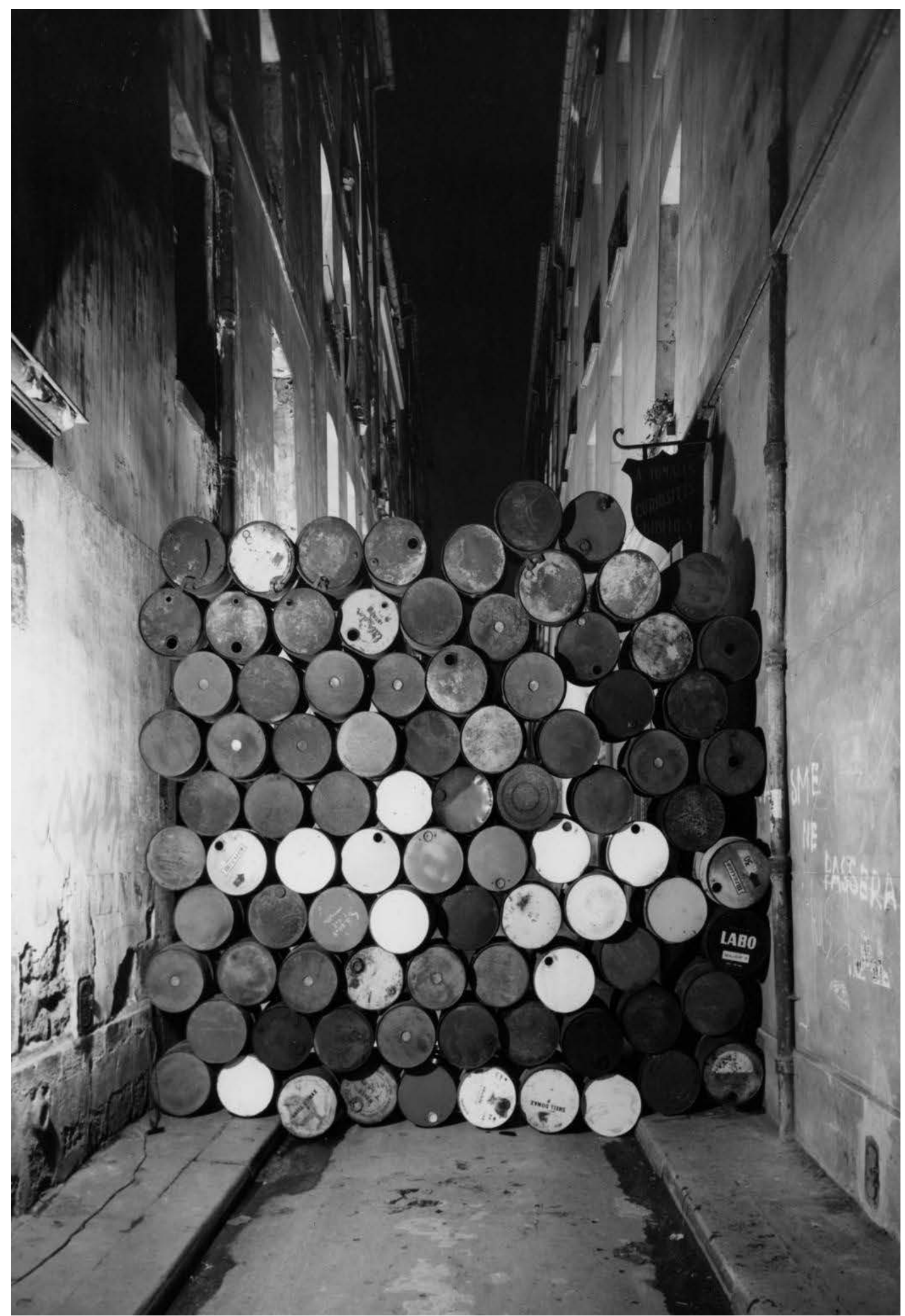

Christo e Jeanne-Claude, Wall of Oil Barrels - The Iron Curtain, Rue Visconti, Paris (1961) 
Esta estética de resistência proposta pela Situacionista Internacional, tão claramente baseada em um mandato ideológico-político serviu para revelar contraditoriamente o espaço da praia como espaço urbano ideal. Nos seus gestos os espaços conquistados temporariamente não se transformaram em espaços públicos permanentes ficando assim apenas a sua imagem. A praça urbana é em si uma outra demonstração desta estética de resistência, agora consolidada como espaço público. Localizada entre a condição temporária e a condição de permanência a praia assume cotidianamente ambas qualidades. A diferença é que nos situacionistas de maio de 68 a expressão de deu pela força - gesto que não sobreviveu enquanto a resistência da praia urbana se dá pelo desejo coletivo de preservá-la como espaço público. A praia urbana seja talvez a expressão maior de um ideal democrático expresso através de um espaço público coletivo.

A Situacionista Internacional motivou alguns avanços políticos, especialmente na sua participação junto ao movimento estudantil de maio de 68 , mas foi criticada veementemente pelas contradições encontradas entre as posições teóricas herméticas para muitos e a então fatal distância entre o grupo e os movimentos trabalhistas e estudantis, formando uma aliança elitista e de esquerda, uma das maiores contradições dentro do grupo. Mas, se por um lado a SI deixou uma herança política ambígua, considerando-se a limitada visão crítica da realidade e dos protocolos políticos viáveis para avançar uma suposta mudança radical da sociedade, é incomensurável a importância da sua influência nas artes, especialmente nas práticas que se sustentam pelo engajamento do espaço público urbano. A psicogeografia, um dos baluartes metodológicos estabelecidos por Guy Debord e seus precursores, iniciou uma nova tradição na leitura crítica dos espaços urbanos a partir do "estudo de efeitos específicos do ambiente geográfico, conscientemente organizado ou não, baseado nas emoções e comportamentos de indivíduos" ${ }^{77} \mathrm{Na}$ cultura atual a psicogeografia é tão ubíqua, tão presente na vida do intelectual, pesquisador, estudante, artista urbano, arquiteto e em todos aqueles que estão envolvidos no estudo da cidade que nem percebemos mais a sua real dimensão, um modus operandi.

Aqui a imagem do flâneur se renovou, influenciada pelas novas sensibilidades e percepções de um espaço urbano cada vez mais denso e complexo. Se o flâneur original buscava o anonimato e a vagueação sem nenhum intuito específico, agora o flâneur da segunda metade do século 20, imerso na metrópole em constante metamorfose, estrutura uma

\footnotetext{
${ }^{77}$ Ken Knabb, Situationist International Anthology, p. 143.
} 
sensibilidade consciente, intencional, objetiva, e com um claro produto proveniente da experiência, como, por exemplo, os mapas psicogeográficos. Debord redefine flânerie e prefere o termo dérive ou détournement, para indicar exatamente a claridade de tais mudanças, do estado inconsciente do flâneur original, em direção a uma carga significativa de desejos políticos e sociais, ${ }^{78}$ buscando caminhos para a revolução do cotidiano, a ser documentado e circulado pelos meios da avant-garde política, e posteriormente, artística. No interior da Situacionista Internacional vários exemplos destas novas técnicas de mapeamento surgiram. The Naked City ${ }^{79}$ e Guide psychogéographique de Paris, ambas de 1957, se tornaram exemplos clássicos da nova atitude.

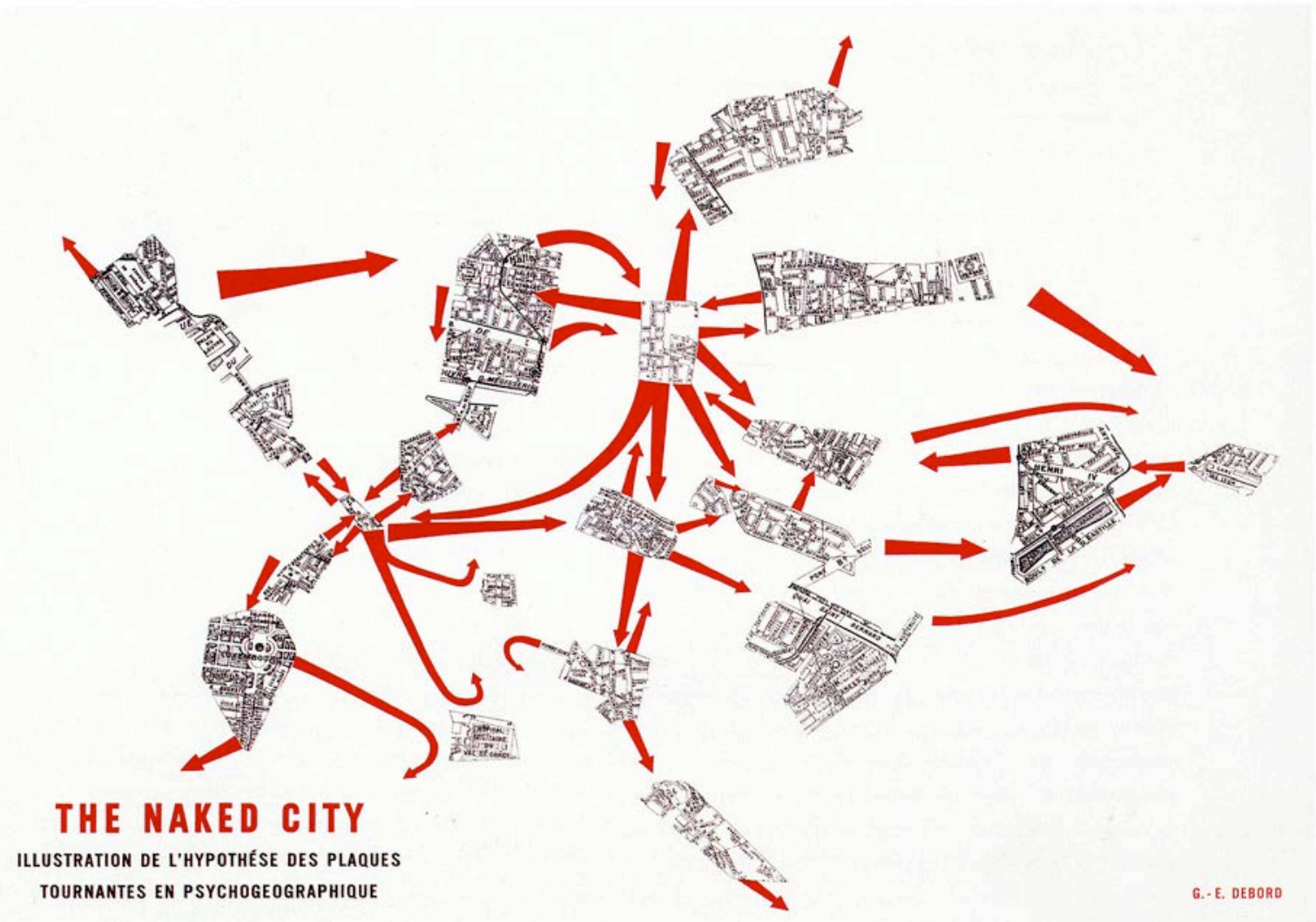

Guy Debord, The Naked City (1957)

\footnotetext{
${ }^{78}$ Estéticos também, mesmo considerando que os membros da SI negavam tal finalidade.

79 "The Naked City, um mapa realizado por Guy Debord, ilustra a preocupação dos situacionistas com a construção e percepção do espaço urbano. 0 mapa é composto por 19 secções recortadas de um mapa de Paris, impresso em tinta preta, que são conectados com setas vermelhas demonstrando a invenção de novos distritos, o seu deslocamento sobre as relações espaciais e seus grandes espaços brancos não-realizados. The Naked City visualiza uma cidade fragmentada que é o resultado de múltiplas reestruturações de uma sociedade capitalista, e a própria forma de uma crítica radical da sociedade." Descrição de Tom McDonough, Cambridge, Mass.: October 67, Inverno 1994, pp. 58-77.
} 
Então qual seria a herança situacionista no contexto da praia? O situacionismo gerou três condições influenciadoras que ajudam explicitar o fenômeno da praia e neste processo expor praiapaisagem: 1] Não poderíamos considerar todos aqueles que engajam diretamente com a praia hoje flâneurs contemporâneos? 2] O projeto situacionista quando idealizou o espaço público encontra na criação, desenvolvimento e implementação de praias urbanas no mundo todo a concretização do seu ideal. Não seria Paris Plage a manifestação deste último gesto? Sem se impor pela força a permanência de Paris Plage no seio da cidade surge agora como um gesto delicado, leve e moderado, sendo uma resposta ao mandato situacionista original, estabilizado exatamente pela geração de maio de 68 que agora ocupa os cargos políticos que permitem a criação e consolidação de espaços públicos deste gênero. Então este desejo, o sonho pela praia, extravasou o movimento estudantil e invadiu a cultura popular. 3] A proliferação dos meios de registros digitais é uma resposta direta à psicogeografia, uma prática comum e leviana na sua maioria, mas que mapeia intensamente e constantemente a situação urbana.

II_Os anos 1960 e a descoberta da rua

Artistas captaram a importância da psicogeografia de imediato, e, a partir dos anos 1960 uma mudança dos hábitos representacionais da cidade tomou conta desta geração. Os novos procedimentos ultrapassaram a ideia da cidade como tema, e a cidade se tornou o próprio cenário da ação através da utilização de técnicas psicogeográficas (cognitivas de mapeamento) como técnica de registro da experiência, e até como a experiência em si. A proximidade sensível e ideológica com a Situacionista Internacional fez do grupo Fluxus um dos maiores incorporadores das tácticas de détournement, especialmente através da criação de happenings. Benjamin Petterson e Robert Filliou organizaram tours de Paris e Nova York que duravam o dia inteiro, na qual encontravam-se com pessoas no caminho que tinham sido informadas do evento a partir de folhetos instrucionais. Yoko Ono escreveu partituras nas quais convidava as pessoas para "caminhar por toda cidade com um carrinho de bebê vazio ou pisar em todas as poças de água da cidade" (City Pieces, 1961). ${ }^{80}$ Jenny Holzer espalhava os seus famosos truísmos através de posteres pela cidade, enquanto Daniel Buren criava

\footnotetext{
${ }^{80}$ Christel Hollevoet, "Wandering in the City: Flânerie to Dérive and After: the Cognitive Mapping of Urban Space". In The Power of the City, the City of Power. New York: Whitney Museum of American Art, 1992, pp. 35-36.
} 
coreografias específicas a serem seguidas por grupos que conduziam os seus estandartes de faixas (Seven Ballets in Manhattan, 1975), e Stanley Brouwn pedia para passantes desenharem o mapa do melhor caminho para algum destino aleatório (This way Brouwn, 1961). Mesmo que seguindo uma trajetória paralela, o Teatro do Oprimido de Augusto Boal utilizava tácticas, muitas vezes mais efetivas e consequentes que artistas de vanguarda e da SI, que podem ser consideradas partes deste mesmo processo de détournement, especialmente através das improvisações psico-políticas em espaços públicos realizadas em Paris e Nova York nos anos $1960 . .^{81}$

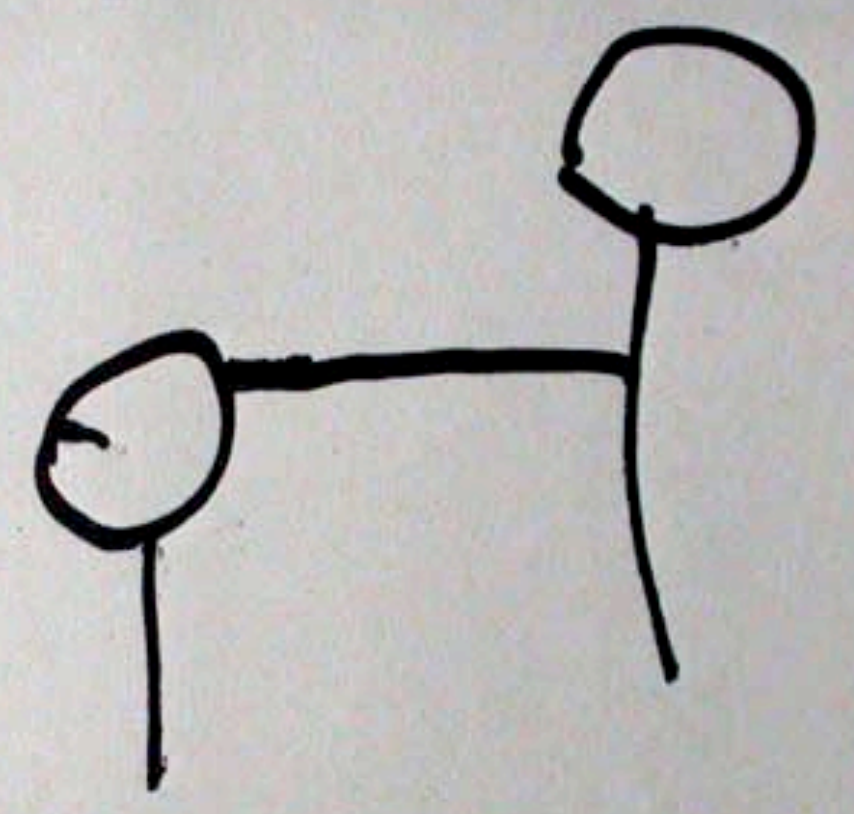

\section{this way brouwn}

Stanley Brouwn, This way Brouwn (1961)

Havia assim um novo espírito coletivo da vanguarda, o qual dignificava a experiência urbana acima do objeto da arte através de formas alternativas de engajamento com o público, e métodos simples de registro da experiência, muito próximos dos procedimentos da arte

\footnotetext{
${ }^{81}$ Nota-se que em 1992 Boal foi eleito vereador no Rio de Janeiro utilizando-se das mesmas técnicas.
} 
conceitual. Vito Acconci, iniciado como poeta, passou a desenvolver técnicas de rastreamento urbano. Em Following Piece (1969), Acconci escolhia e seguia indivíduos na rua até que eles deixassem o espaço público. Acconci personifica o novo flâneur, pois, se o seu destino é desconhecido, o objeto da sua procura tem um foco específico, na pessoa a quem segue. $\mathrm{O}$ mais intrigante é o registro da própria ação, pois o fotógrafo, aquele que caminha nas costas de Acconci, permanece anônimo durante a ação, como uma sombra do artista. A imagem da sombra é reiterada de maneira mais meticulosa no trabalho de Sophie Calle (Suite Vénitienne, 1979), e como Acconci, ela decide um dia seguir nos rastros de um indivíduo que ela pouco conhecia. Ela descobre que ele partiria de Paris para Veneza e ela o segue nesta viagem. Chegando em Veneza descobre onde ele se hospeda e convence o vizinho no edifício da frente do hotel a alugar um quarto para a sua estadia na cidade. Do quarto ela observa todos os passos deste, seguindo-o quando possível. Simultaneamente ao ato ela o fotografa e publica um diário (textos e imagens) no jornal Libération, transcrevendo todas as suas observações. Aqui, o ato anônimo clandestino de Calle faz contraponto com a apresentação totalmente pública do trabalho, expondo o seu autor no diário parisiense. A obra é então relocalizada e recaracterizada pelos deslocamentos nos quais se submeteu, e pela sua transposição num veículo mediático. Tal exacerbação da imagem da sombra é salientada por Jean Baudrillard como um desaparecimento final:

\footnotetext{
0 ato da sombra faz o outro desaparecer no inconsciente daquele que o segue, nos traços que deixa para trás - Veneza é uma cidade extinta, onde toda a história desapareceu e onde alguém desaparece - e a fotografia é em si a arte do desaparecimento, que capta o desaparecido em frente da lente e preserva-o em filme, o que, diferentemente do olhar, não guarda nada do outro mas somente a sua presença ausente. De acordo com Barthes não é bem a morte que pode ser lida aqui mas sim o desaparecido. Morte é a fonte moral do medo, desaparecimento é a única fonte "sedutora" da estética do desaparecimento. ${ }^{82}$
}

O vai-e-vem do flâneur contemporâneo, entre presença e ausência, entre consciência e um estado de torpor, entre a realidade da cidade e a abstração interior, entre o fazer e a representação, é confirmada pelo espaço mediático baudrillardiano que vai desde a tela da TV até o pára-brisa do carro como campo de relações. Alguém que trafega num congestionamento está num estado de consciência e ausência (abstração) constante, como uma faísca que, sem parar, move o pistão do mesmo automóvel. Este estado entre presença e

\footnotetext{
82 Jean Baudrillard, Please follow me. Disponível em: <http://www.sophiecalle.net/wrtings.htm>. Acesso em: 18 de fevereiro de 2012, tradução nossa.
} 
ausência, entre consciência e torpor condiciona também aquele que experimenta a praia: algo entre o ócio e o lazer, entre a reflexão lúcida, o pensamento criativo e a imaginação devaneia. A experiência da praia promove e enfatiza esta condição pois entre o indivíduo e o coletivo, entre o espaço pessoal interno e as aberturas às trocas sociais, muitas vezes reforçadas pelos aspectos sedutores do ambiente, o calor e a brisa, os sons, corpos seminus e olhares constantes, e até mesmo o deambular daqui para ali são comparações próximas às experiências vanguardistas que compreenderam o espaço público e o papel do flâneur como material performático, e a relação incógnita entre as pessoas, e entre as pessoas e o lugar, como fonte do pensamento criativo. Esta experiência, passando ou não por um processo de registro, assume vividamente o caráter da psicogeografia, o que ocorre no caso da praia, na sua maioria, de modo inconsciente.
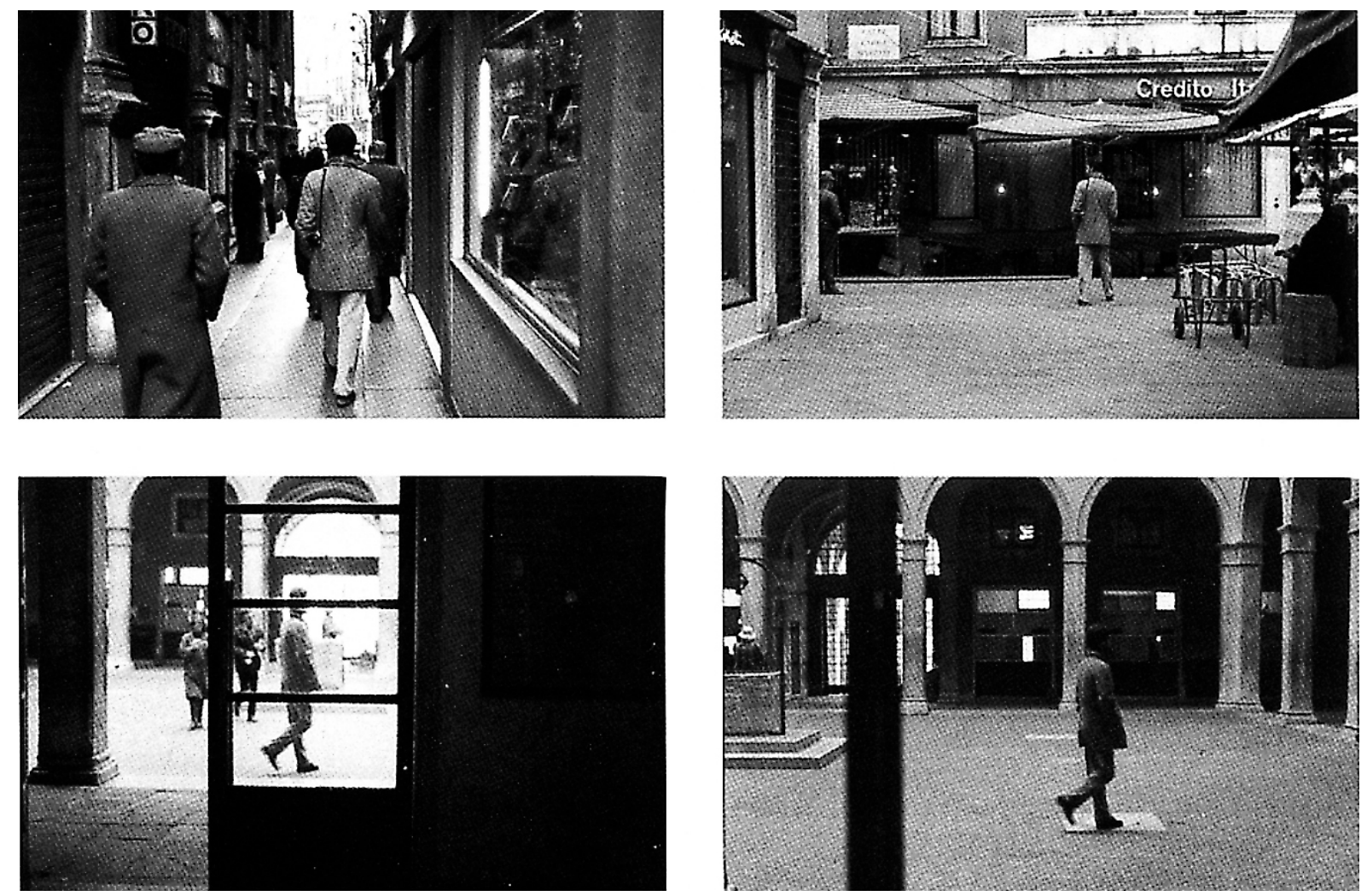

Sophie Calle, Suite Vénitienne (1979) 
III_A rua como prática contemporânea

A materialização da rua como prática contemporânea promove uma expressão maior, mais explícita do sentido "público". Se por um lado é imperativo reconhecermos historicamente o processo de transição do ateliê para a rua, são nas práticas contemporâneas que observamos o exercício crítico que contribui na formação de praiapaisagem. O artista público contemporâneo detecta através do seu trabalho as questões mais prementes relativas à cidade e assim detecta e provoca significantemente as questões urbanas mais urgentes. Neste espírito o artista belga-mexicano Francis Alÿs (que obteve educação formal em arquitetura) se desloca pela cidade a pé, mas se difere de Vito Acconci e Sophie Calle no que visa: não o parceiro andarilho urbano anônimo, mas as dinâmicas sociais do espaço da rua. Em Alÿs a cidade surge como um local de descobertas que tem reveladas suas contradições no ato de andar.

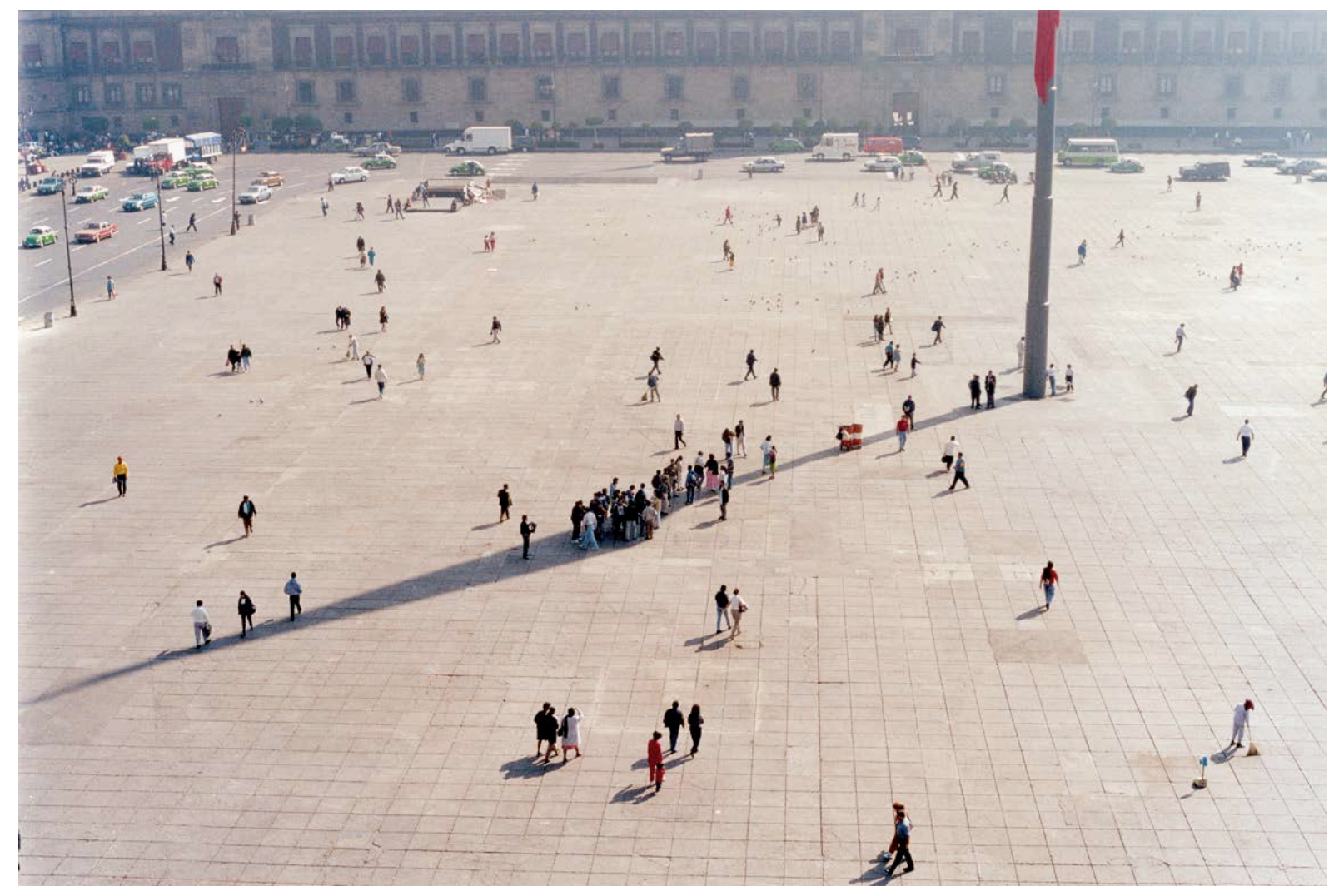

Francis Alÿs, Zocalo, México City, 1999

Em Paradox of Praxis (1997), o artista empurrou um bloco de gelo comercial pelas ruas da Cidade do México até ele se derreter. Aqui o "objeto de arte" desaparece no ato da 
obra, mas deixa um traço, mesmo que momentâneo, do trajeto do artista na cidade. $\mathrm{O}$ traço então, associado ao próprio deslocamento do corpo do artista, viram a obra em si. O tempo substitui o bloco de gelo perdendo então a sua aura enquanto objeto. Em O Colecionador (1991), um cachorrinho de brinquedo sobre rodas que ele leva para passear todos os dias, é coberto por imãs, coletando assim detritos metálicos encontrados pelas ruas. Em Reenactment (Re-dramatização, 2000) ele anda pelas ruas da Cidade do México com uma Beretta de $9 \mathrm{~mm}$ na mão direita até ser preso pela polícia. Em São Paulo, Alÿs andou pelas ruas de Pinheiros com uma lata de tinta na mão com um furinho em baixo, marcando o percurso caminhado até a tinta acabar. Nos seus atos urbanos Francis Alÿs investe no contexto cultural coletivo através de uma relação direta com o seu público (da rua) e aborda questões sociais das mais variadas seja pelos fragmentos folclóricos de uma economia instável (O Colecionador), pela percepção suspensa de um ato absurdo (Paradox of Praxis), ou pelo caráter psicológico que o espaço urbano sustém (Re-enactment).

Em relação a experiências muito mais próximas de nós tivemos em São Paulo a ação contínua entre 1979 e 1982 do grupo 3NÓS3 (Hudnilson Jr., Rafael França e Mário Ramiro) ${ }^{83}$, que realizaram vários projetos de espírito situacionista, onde o deslocamento dentro da cidade, a ativação de ingerências em ícones urbanos (estátuas, monumentos, viadutos e túneis), adjacente a uma técnica de marcações no território, formavam o princípio central do grupo. Alegam a influência direta das ações urbanas de Flávio de Carvalho dos anos 1930 aos 50, e também de Hélio Oiticica, especialmente com Delirium Ambulatorium e eventos como Apocalipopótese (RJ) e Mitos Vadios (SP). ${ }^{84}$ Desde Baudelaire várias práticas baseadas na modernidade do flâneur surgiram durante o século 20, e, sendo reinventadas pela SI como medida e crítica de situações urbanas com intuito político de desmantelar o urbanismo oficial através da psicogeografia do mapeamento cognitivo, alcançando esta última passagem de século plenamente absorvida e adaptada por práticas contemporâneas. ${ }^{85}$ Seria tal aceitação

\footnotetext{
${ }^{83}$ Para um apanhado detalhado das ações do Grupo 3Nós3, veja o artigo "The Outside Expands" de Mário Ramiro, revista Parachute, Montreal, número 116, 2004, pp. 41-53.

${ }^{84}$ Para um apanhado histórico especificamente do caso brasileiro ver o artigo de Paola Berenstein Jacques, “Elogio aos errantes: Breve histórico das errâncias urbanas". Disponível em: <http://www.vitruvius.com.br/arquitextos/arq000/esp256.asp>. Acesso em: 24 de janeiro de 2012.

${ }^{85}$ Mais recentemente uma pletora de grupos e indivíduos investindo em estratégias de flânerie, dérive ou détournement como Stalker (Itália), Ministry of Walking e Janet Cardiff (Canadá), Free Walking (Chicago), tem surgido com as mais variadas agendas: artísticas, de pesquisa ou políticas. Para um apanhado completo da prática do caminhar como pratica artística ver o trabalho de Francesco Careri, Walkscapes: El andar como práctica estética. Barcelona: Gustavo Gili, 2001.
} 
geral resultado do massivo crescimento dos centros urbanos nos últimos cem anos, surgindo como necessidade inexorável de compreender-se definitivamente as relações físicas, sociais e fenomenológicas com a cidade, agora infinitamente mais complexas que a Paris de le Peintre de la vie moderne?

Mas uma outra aproximação situacionista ainda maior com a praia é a relação entre o lúdico e o status econômico. Os situacionistas entenderam a deriva psicogeográfica como método de "desnudar a cidade", e também como maneira lúdica de reivindicar o seu território, como Francesco Careri comenta:

\begin{abstract}
A cidade é um brinquedo para ser usado como prazer, um espaço para a vida coletiva, para a experiência de comportamentos alternativos, um lugar em que se perde tempo útil de modo a transformá-lo em tempo lúdico-construtivo. Era preciso desafiar essa afluência vendida como felicidade pela propaganda burguesa ... Foi necessário partir do conceito de circulação como um complemento do trabalho e distribuição nas várias zonas funcionais da cidade a um conceito de circulação como prazer e aventura, para assim poder experimentar a cidade como um território lúdico a ser utilizado na circulação de pessoas em direção a uma vida autêntica. 0 necessário era a construção de aventuras. ${ }^{86}$
\end{abstract}

Se por um lado vimos que o espaço urbano se tornou um novo campo das práticas estéticas pelos processos evolutivos da flânerie, voltemos a Mondrian e o seu mantra: "integrar os espaços interiores domésticos com a rua, com a cidade, criando uma integração de espaços mas também uma integração da vida”. Se Hélio Oiticica se aproximou das condições públicocomunitárias, inicialmente pela sua experiência com a favela carioca, como base do seu projeto construtivo, carregava no seu processo a consciência da integralidade mondriana:

Talvez não tenha Mondrian deixado nenhuma específica instrução quanto a isso; mas quando vemos as fotos do seu ateliê em Nova lorque, com a ambientação que criara para a condição, para o nascimento de cada obra sua, vemos que estas viviam muito mais ali, antes de entrarem no consumo "cultura-comércio" em que se transformaram posteriormente, guardadas delicadamente atrás de grossos vidros em salas atapetadas etc. Por que então, para sermos fiéis ao pensamento do artista, não se reconstituem os seus ambientes pelas fotos?... Agora, com o tempo e as novas experiências, outro problema bem mais grave aparece: o do recinto-obra, indeslocável pela sua natureza, ou seja, o lugar-recinto-contexto-obra, aberto à participação, cujos significados são acrescentados pela participação individual neste coletivo... casa-obra como realização estética da vida, ou seja, a aplicação de uma determinada estrutura, que seria a mais universal possível (ortogonal de Mondrian),

\footnotetext{
${ }^{86}$ Francesco Careri, Walkscapes: El andar como práctica estética. Barcelona: Gustavo Gili, 2001, p. 108, tradução nossa.
} 
levando a um comportamento adequado aí adquirido, ou que fosse resultado de um comportamento estético da vida... sua proposição que hoje nos interessa: totalidadeobra. ${ }^{87}$

Não se trata aqui de uma genealogia cronológica, pois não sabemos se Oiticica conhecia Home-Street-City de Mondrian, ou mesmo Door: rue Larrey de Duchamp, mas sim de uma sincronicidade de ideias e proximidades onde tais questões acabam achando um caminho comum no pensamento, o que atesta tão eloquentemente as observações e a própria obra de Oiticica. Esta transformação do objeto através do contexto encontra o que Oiticica chama de totalidade-obra (uma alusão ao termo germânico Gesamtkunstwerk). O caráter essencial desta nova natureza do objeto é a indissociabilidade com o espaço da arquitetura, um lugar onde não mais existem distinções entre a obra de arte e a arquitetura onde ela existe, onde a obra é inteiramente integrada ao espaço. Esta coexistência gera um novo apelo estético, um novo valor impregnando arquiteturas com a poética e as escolhas estéticas provindas da vanguarda artística. Esta totalidade-obra que Oiticica propõe encontra na praia uma outra evidência marcante: uma superfície urbana flexível que acumula e organiza uma experiência totalizante entre o corpo e o lugar.

Na definição do próprio lugar, Yves Klein também experimentou um lugar onde não mais existem distinções entre a obra de arte e a arquitetura onde ela existe, um conceito que praiapaisagem reconhece, isto é, um lugar onde as demarcações entre o corpo e o lugar, entre a cidade, a arquitetura e a paisagem são dissolvidas. Previamente, na sua fase monocromática, Klein reduz a pintura à sua materialidade essencial e sintetiza a experiência cromática visual a uma cor única, o azul, e vai mais adiante ao escolher uma tonalidade única, que ficou conhecido como o azul Klein, patenteada, derrubando qualquer predisposição perante a obra de arte: a cor agora é a cor pura e não aquela associada ao gosto, às preferências individuais. Em 1958 Yves Klein instaurou um importante precedente com o seu trabalho Le vide. Em Le Vide Klein esvazia a galeria Iris Clert, pinta-a de branco, e convida 3500 pessoas para a exposição. ${ }^{88}$ Para a surpresa de muitos não havia nada no espaço da galeria, e lá habitava

\footnotetext{
${ }^{87}$ Hélio Oiticica, "A obra, seu caráter objetal, o comportamento", em Aspiro ao grande labirinto. Rio de Janeiro: Rocco, 1986, pp. 118-119.

88 'Le Vide. Iris Clert vous convie à honorer, de toute votre présence affective, l'avènement lucide et positif d'un certain règne du sensible. Cette manifestation de synthèse perceptive sanctionne chez Yves Klein la quel le picturale d'une émotion extatique et immédiatement communicable. Lundi 28 Avril 1958, h. 21. Iris Clert, 3 rue des Beaux-Arts, Paris." In Dominique Bozo, Yves Klein 1928-1962 - A Retrospective, Institute for the Arts. Houston: Rice University, 1982.
} 
exatamente o cerne da intenção - que o espaço na sua forma mais pura era o espaço ideal a ser conquistado:

Período Pneumático: 0 objetivo deste esforço: criar, estabelecer, e apresentar ao público um estado pictórico palpável nos limites de uma galeria de pinturas. Em outras palavras, a criação de uma ambientação, um clima pictórico genuíno, e, portanto, invisível. Este estado pictórico invisível dentro do espaço da galeria deveria ser tão presente e dotado de vida autônoma que deveria literalmente ser o que então tem sido considerada a melhor definição de pintura: resplendor. ${ }^{89}$

A elegante estética kleiniana veio selar a união entre o espaço pictórico da tela com o espaço da galeria, transformando-os numa ambientação, um clima pictórico genuíno. Klein salienta que aquele espaço é ainda pictórico, pois impregná-lo com algum uso seria eliminar o sistema de significações que tinha articulado até aquele momento. Assim, ao negar o espaço da galeria como arquitetura, ele determina uma qualidade para a arquitetura que é o equivalente à sua melhor definição de pintura: resplendor.${ }^{90}$ Com tal gesto Klein realiza uma abertura na maneira de olhar o espaço da galeria, e mais do que isso: as relações entre o objeto de arte e o espaço da galeria. Le Vide representou uma atitude proto-minimalista, ajudando a desencadear as mutações ocorridas no objeto durante os anos 1960. Poucos anos depois, em 1964, Dan Flavin criou Monumento para V. Tatlin, no qual dispôs uma série de tubos fluorescentes comerciais, não modificados, no espaço da galeria. A própria presença deste objeto trivial é o que permite a sua observação, pois ele mesmo é a fonte de luz, e por ser um objeto de presença comum no cotidiano, esta familiaridade com o cotidiano, é o que o faz desaparecer como objeto [de arte]. O que sobra é o entre-espaço, entre objeto e galeria. De certa forma Monumento para $V$. Tatlin pode ser considerado uma síntese dos procedimentos de Duchamp (o readymade), com os de Klein (o monocromático / a galeria vazia), e num momento cultural tão generoso como foram os anos 1960, tais energias se fundiram e emplacaram como uma nova instrumentação do objeto que agora se expandia nas relações com o espaço da galeria. A partir deste momento o reconhecimento do espaço da galeria

\footnotetext{
${ }^{89}$ Idem.

${ }^{90}$ Basta notar que durante o evento um estudante atentou desenhar em uma das paredes e foi veementemente admoestado por Klein, que o expulsou da galeria, como se as paredes assumissem uma vocação idêntica à da tela em relação à pintura.
} 
como parte da experiência da obra ficou evidente para uma toda geração de artistas. ${ }^{91} \mathrm{O}$ minimalismo, mesmo nas suas limitações, tinha chegado definitivamente para ocupar um lugar de destaque naquela contemporaneidade.

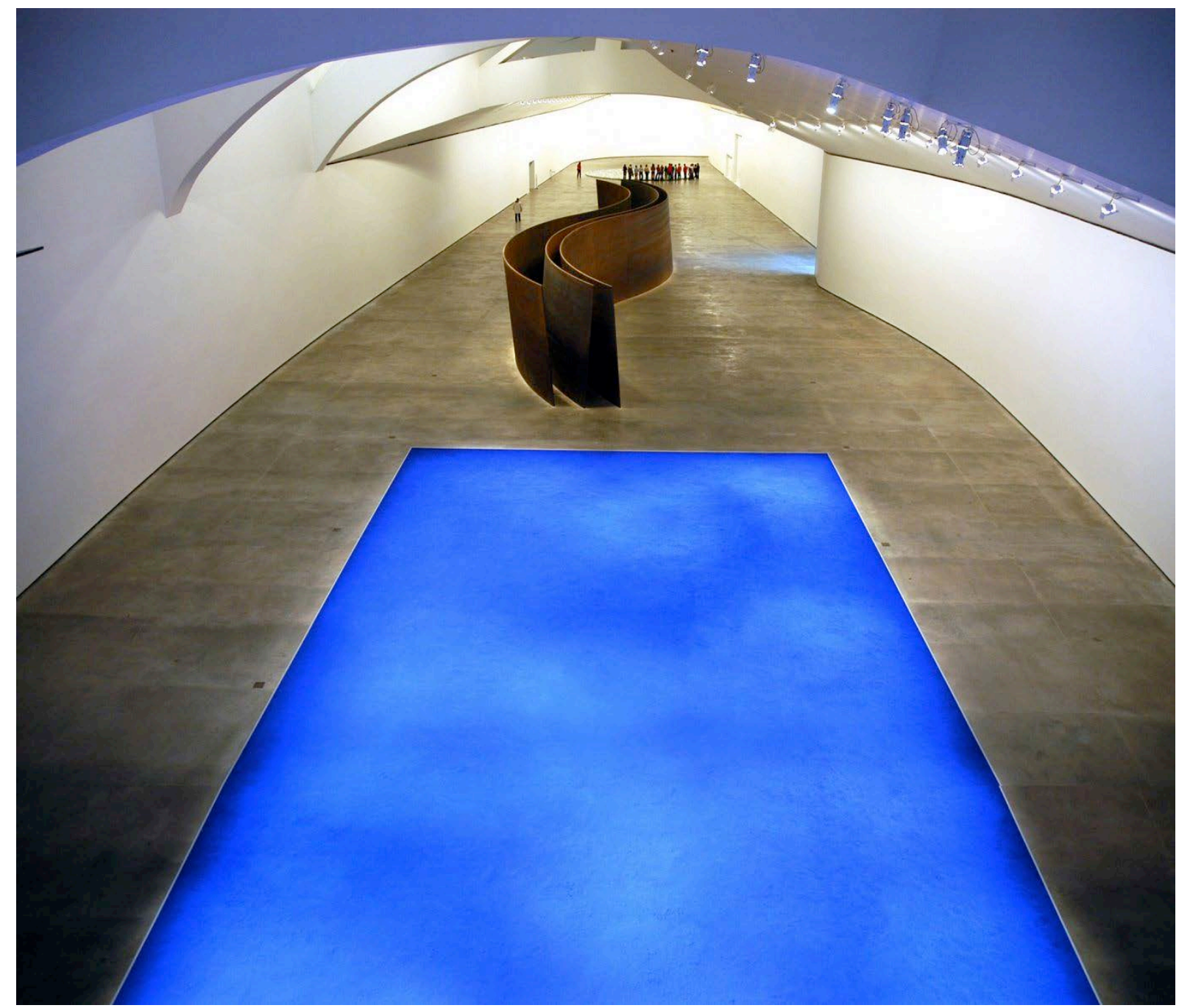

Yves Klein e Richard Serra no Guggenheim de Bilbao

A experiência minimalista dos anos 1960 foi em grande parte restringida ao espaço da galeria, limitada aos usos de materiais e técnicas industriais, e, mesmo que reconhecendo a percepção do espaço como parte da obra, tinha pouca capacidade de engajamento com o público. Assim sendo, mostrava certas fragilidades que motivaram muitos dos artistas mais

\footnotetext{
${ }^{91}$ Carl Andre, Robert Morris, Richard Serra, Mary Miss, Alice Aycock, Dan Flavin, Sol LeWitt, Frank Stella, Donald Judd, Robert Irwin, Robert Smithson, Nancy Holt, Larry Bell, Michael Heizer, dentre tantos outros.
} 
jovens a se enveredarem por outras direções. ${ }^{92}$ Mesmo que iniciando as suas atuações dentro do grupo minimalista, Robert Smithson e Dan Graham identificaram algumas deficiências no novo vocabulário, e acabaram por extrapolar os preceitos estabelecidos, aprofundando-se assim nas suas pesquisas pessoais. Dan Graham se interessou pelo aspecto social do objeto tanto materialmente, através do uso frequente de espelhos semitransparentes / semirefletores, que permitiam o visitante observar tanto o entorno como a si mesmo, e também investiu no programa do objeto, quando começou a projetar pequenos pavilhões em parques e loci urbanos específicos, incorporando-os com atividades definidas como assistir a vídeos, observar a paisagem ou a si mesmo em relação à paisagem, sentar, olhar, passar, etc.

Robert Smithson alterou as suas proposições para além da galeria, trabalhando na escala da paisagem (Land art) e na escala da arquitetura. Um projeto em particular estruturase entre estas duas entidades: a paisagem e a arquitetura. Em Partially Buried Woodshed ${ }^{93}$ (Kent State University, Ohio, 1970), Smithson enterrou parcialmente uma estrutura abandonada no campus da universidade. A idéia de enterrar uma estrutura já existia, e foi então o caso de simplesmente encontrar uma estrutura adequada para poder realizar o projeto. A terra foi acumulada no telhado do prédio até romper a viga principal, o que definitivamente destituiu a estrutura do seu uso original. Woodshed foi o primeiro projeto Land art de Smithson, e carrega na sua complexidade relações de dentro/fora (passagens originais interrompidas, novas aberturas criadas pela destruição); de características ficcionais (às vezes parece um cenário de um acidente, outras de uma demolição); de materialidade (de qualquer ângulo que é abordada, de dentro ou de fora, se observa a terra e a construção simultaneamente, arquitetura e paisagem em coexistência); e de tempo (como muitos dos projetos de Smithson Woodshed sempre se transformou com o discorrer do tempo - em constante mutação, nunca manteve as mesmas qualidades dois dias seguidos, representando um grande desafio para a instituição que a possui, a Kent State University, para mantê-la ou

\footnotetext{
${ }^{92}$ É convencionalmente reconhecido que a tendência crítica mais direta ao minimalismo, que tentava suprir as suas limitações técnico-formais, ficou conhecida como pós-minimalismo, sendo a arte povera na Europa, mais especificamente na Itália, considerada uma forma de pós-minimalismo. Os representantes maiores na Itália são Giovanni Anselmo, Alighiero e Boetti, Luciano Fabro, Jannis Kounellis, Mario e Marisa Merz, Giulio Paolini, Giuseppe Penone, Michelangelo Pistoletto e Gilberto Zorio. Alguns artistas mais influentes na América seriam Bruce Nauman, Robert Smithson, Dan Graham, Eva Hesse, Gordon Matta-Clark e Félix González-Torres.

${ }^{93}$ Barraco de madeira parcialmente enterrado (tradução nossa).
} 
mesmo de preservá-la como objeto de arte. A natureza do objeto foi reinventada ao assumir esta dupla personalidade de arquitetura/paisagem.

Tais procedimentos incorporaram na constituição da obra elementos convencionalmente vinculados à arquitetura, como o site-specific, a possibilidade de introduzir a ideia de programa no corpo da obra, a relação integral com a paisagem e a utilização de técnicas ligadas à construção. Estas estratégias abriram novas possibilidades para o objeto de arte e também estimularam a arquitetura a desenvolver um diálogo com os discursos artísticos. Este curto-circuito da produção e do pensamento acabaram influenciando a própria produção crítica da arquitetura revitalizando as relações arte/arquitetura. Quando em retrospecto olhamos para a praia em relação a estes novos processos verificamos a manifestação de dinâmicas paralelas, mas agora fora dos parâmetros institucionais de produção e ao invés no interior do espaço público. Tais relações são experimentadas de maneira equivalente: o quiosque e a barraca são análogos ao pavilhão de Graham, a areia e seus deslocamentos análogos à paisagem de Smithson, e as mudanças cotidianas de ocupação relacionadas ao programa de arquitetura - a produção pós-minimalista colocou em evidência todos estes comportamentos de lugar.

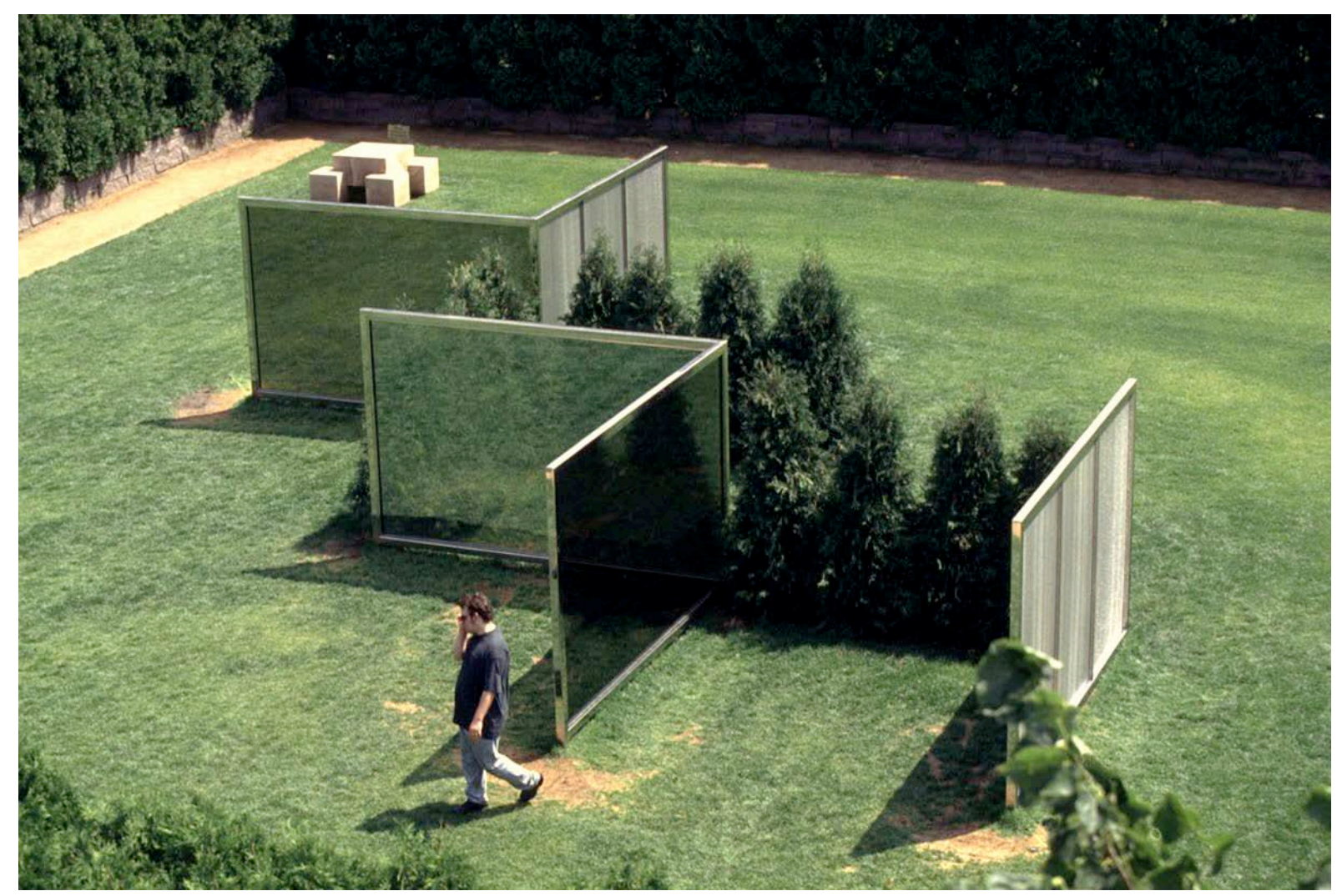

Dan Graham, Two-way Mirror Punched Steel Hedge Labyrinth, Walker Art Center (1994) 

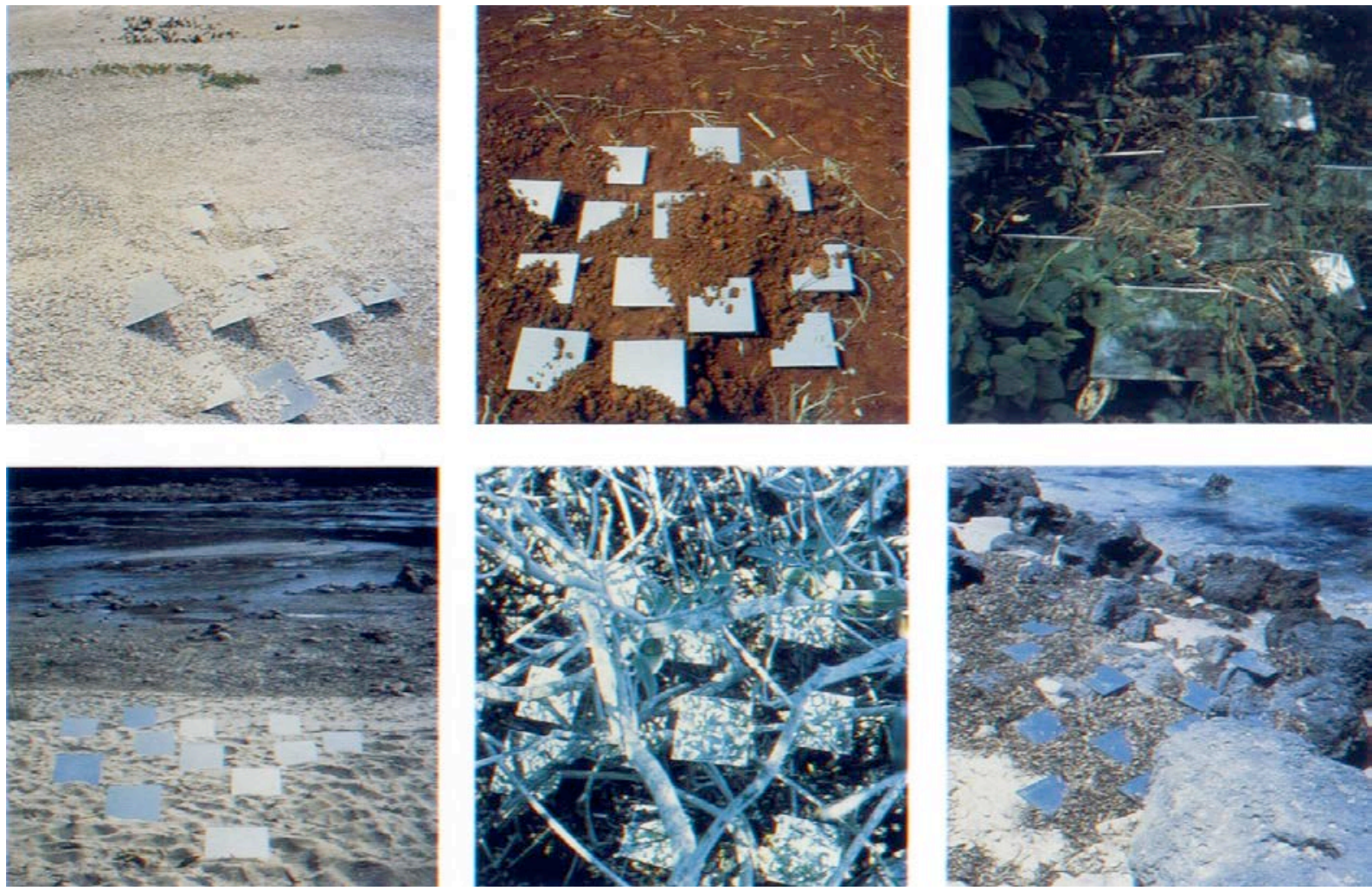

Robert Smithson, Mirror displacements (1969)

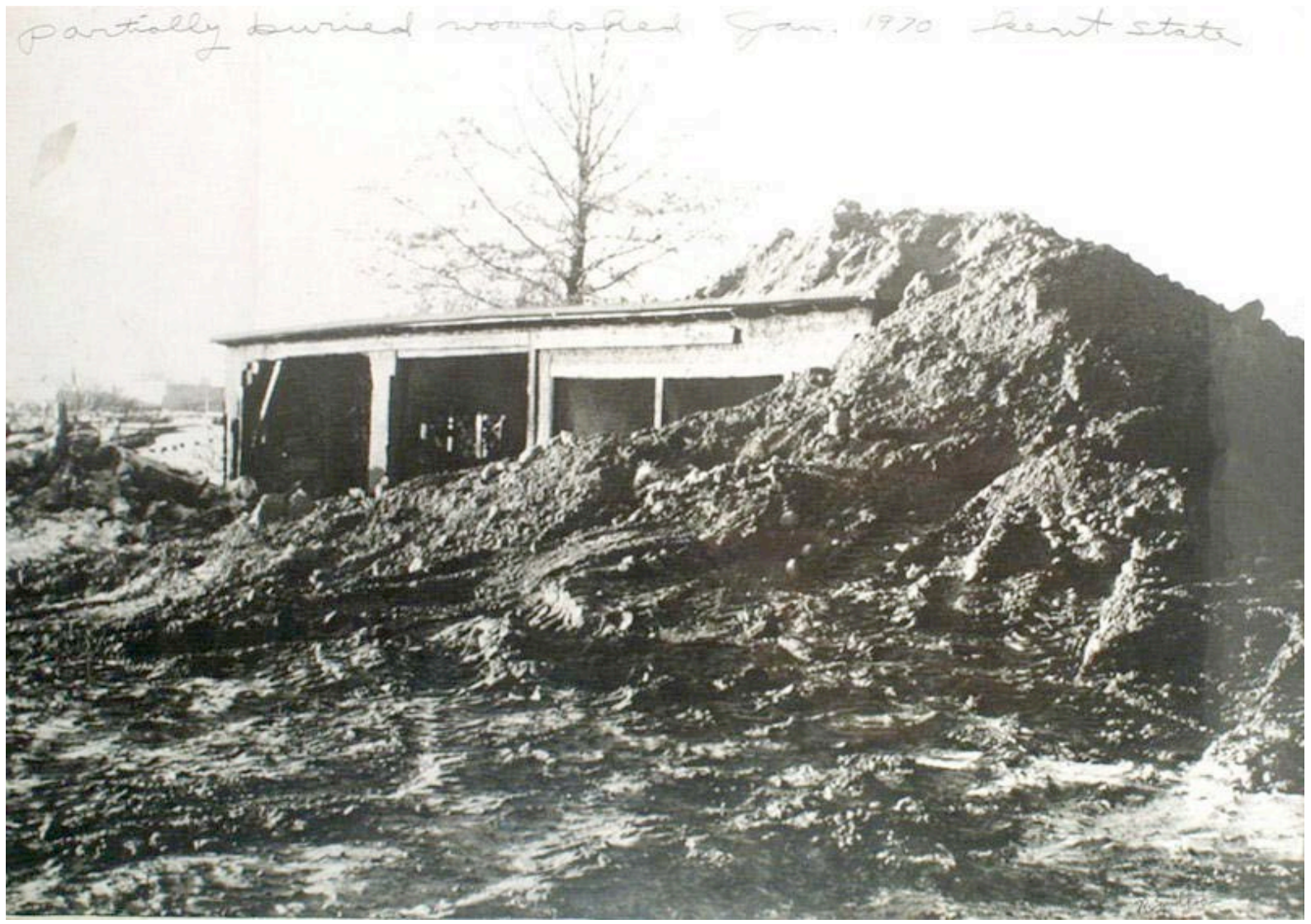

Robert Smithson, Partially Buried Woodshed, Kent State University, Ohio (1970) 
IV_A performance do dia-a-dia: ampliando o campo ampliado

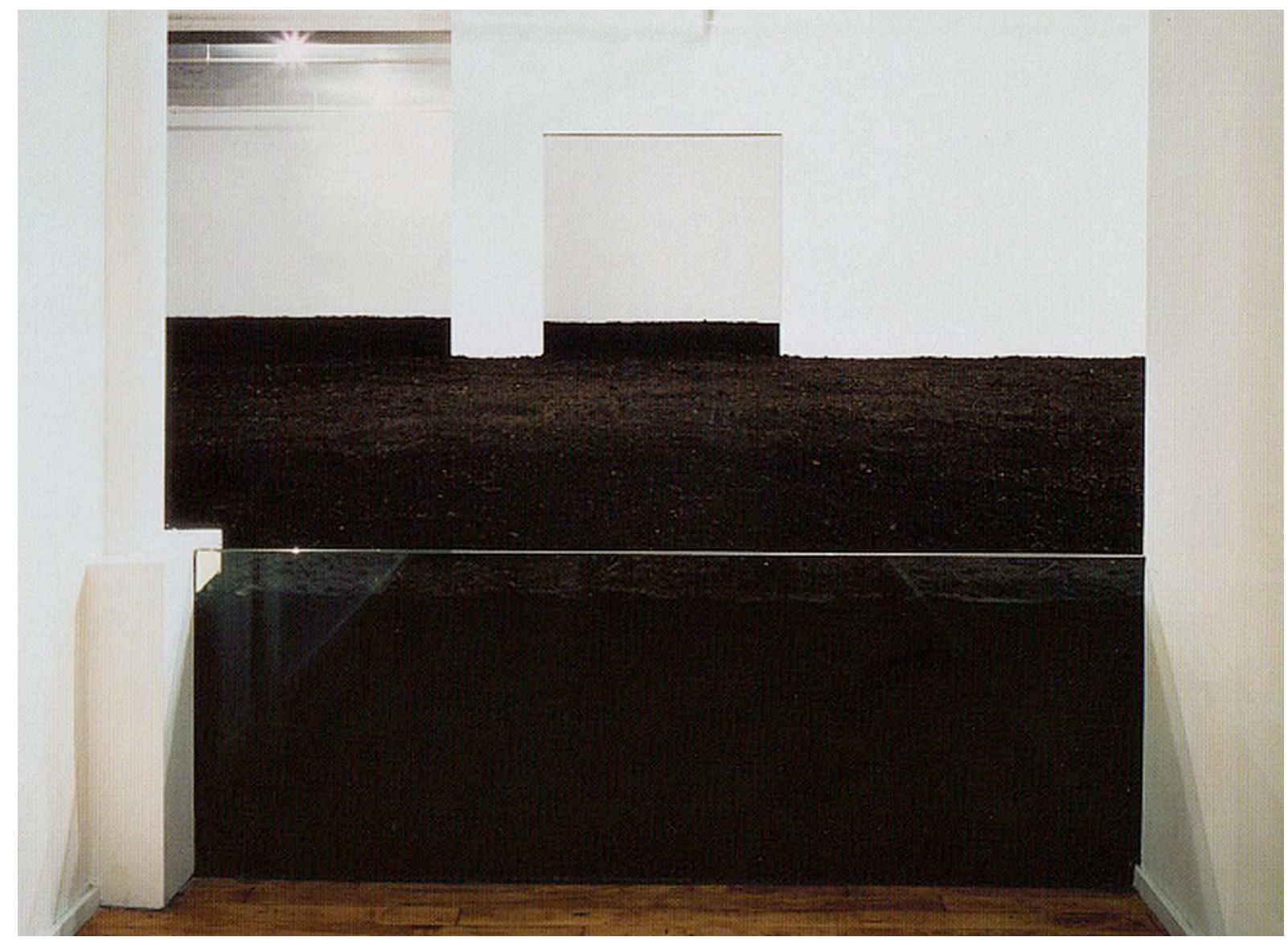

Walter de Maria, New York Earth Room (desde 1977)

Descrevendo um processo ligado à tradição da escultura, Rosalind Krauss definiu estas novas relações como o campo ampliado da escultura. Na época em que escreveu o texto, nos fins dos anos 1970, as sintaxes sendo exploradas tinham atingido uma explosão de procedimentos que não necessariamente podiam ser referenciados com uma terminologia específica e fechada: é isso ou aquilo. Acompanhando o Woodshed de Smithson, e reiterando a concordância arquitetura/paisagem, Walter de Maria preencheu o espaço de uma galeria com terra (New York Earth Room), se tornando a mais longa exposição num espaço de galeria independente da história, em exposição desde 1977. Mary Miss tinha construído uma cavidade subterrânea na paisagem e dado acesso através de uma escada. Robert Morris fabricou dois cubos de espelho e também os colocou num jardim. Bruce Nauman construía corredores com circuitos fechados de vídeo dentro da galeria. Hamish Fulton e Richard Long caminhavam por paisagens remotas e deslocavam materiais encontrados para o espaço da galeria. Denis Oppenheim e Michael Heizer desenhavam na superfície do deserto com 
motocicletas. Richard Serra usava o próprio espaço do ateliê como molde para suas esculturas. Gianni Pettena cobria edifícios inteiros com água no meio do inverno boreal (Minneapolis), gerando um congelamento de caráter fantasma. Robert Irwin fabricava ambientes com telas (scrims) semitransparentes e luz. Gordon Matta-Clark, utilizando-se das mais tradicionais técnicas escultóricas (remover material de uma massa), esculpia a partir de edifícios abandonados. Hélio Oiticica construía os Penetráveis, labirintos de cor e experiência. Seu amigo pessoal, Ferreira Gullar, executou com a ajuda de Oiticica o Poema Enterrado em 1960, no quintal da casa do pai de Oiticica, de certa forma pressagiando as práticas que começavam a germinar. ${ }^{94} \mathrm{Na}$ descrição de Gullar:

\begin{abstract}
O poema-enterrado era o seguinte: é uma sala abaixo do chão, no subsolo. Você desce por uma escada, abre a porta do poema, e entra no poema. É um cubo de 2 metros por 2 metros: uma sala que foi construída no quintal do Oiticica. (Eles iam construir uma caixa d'água, mas aí ele insistiu que tínhamos que construir o poema, e o pai dele, também pirado, construiu.) Era quase como um túmulo. No centro dessa sala tinha um cubo vermelho de meio metro de lado. Então levantava-se o cubo. Embaixo tinha um cubo verde com trinta centímetros de lado. Levantava-se este cubo. Aí sobrava um cubo branco, este, sólido, compacto, de 15 centímetros de lado e pousado no chão. Ao levantar este cubo, sob a face pousada no chão, lia-se a palavra 'Rejuvenesça'. ${ }^{95}$
\end{abstract}

Poema Enterrado assume a arquitetura da caixa, na habitação rigorosamente poética de um recinto, ou, além disso, uma obra aberta que se sustém exatamente das relações de proximidade e significação com as artes plásticas e a arquitetura. A palavra se abre para o espaço e no espaço vira o poema, e o poema espaço, ou como Gullar mesmo afirma: "a única literatura no mundo com um endereço!" Com o Poema Enterrado, ele interrompe prematuramente o seu processo neo-concreto, abandonando os procedimentos de vanguarda do grupo ${ }^{96}$, e volta para a poesia pura via a literatura de cordel declarando: "Quando eu vi isso, eu tomei um susto. Pensei assim: “Onde é que eu vou parar? Não sou arquiteto, não sou

\footnotetext{
${ }^{94}$ Oiticica incluiria depois o Poema Enterrado na sua proposta/multi-instalação Projeto cães de caça de 1961.

${ }^{95}$ Ferreira Gullar em entrevista a Weydson Barros Leal no Jornal da Poesia. Disponível em: <http://secrel.com.br/jpoesia/gular01.html>. Acesso em: 3 de outubro de 2011.

96 “Abati a poesia, calquei-a sob os pés, mijei nela. Lavei as mãos, virei concretista, neoconcretista, enterrei o poema numa casa da Gávea. E sepultei com ele a metafísica." Ferreira Gullar, “Corpo a corpo com a linguagem". Disponível em <http://portalliteral.terra.com.br/ferreira_gullar/porelemesmo>. Acesso em: 23 de junho de 2011.
} 
escultor, não sou artista plástico. Eu vou parar, por aqui não dá pra continuar." ${ }^{97}$ Precoce ainda na sua teorização como em toda nova descoberta, Poema Enterrado se transformou num dos maiores simulacros do neo-construtivismo brasileiro, e com ele ficou um legado de que, um novo espaço, poderia ser sim constituído de pura poesia. Gullar se posiciona ao negar a sua própria condição criadora: "não sou arquiteto, não sou escultor, não sou artista plástico." Negando, ele afirma o sentido determinante e inverso daquilo que o Poema Enterrado era: arquitetura, escultura, arte - elementos interagindo simultaneamente para gerar uma nova experiência estética.

Como Gullar, Krauss havia chegado à sintetização da situação da escultura também pela sua lógica inversa ${ }^{98}$, isto é, pela soma daquilo que não era: não era paisagem, não era arquitetura. Tal sentido, essa pura negatividade que identificava uma combinação de exclusões, começava orientar a compreensão de uma produção coletiva momentaneamente amórfica. Eram situações encontradas nos mais diversos contextos: modificações na paisagem, construções na paisagem, novas construções, construções existentes modificadas, inserções em cenários urbanos, inserções na paisagem, deslocamentos e marcas. Krauss, tentando achar uma definição para tais manifestações, inverteu a sua abordagem explicitando o que não eram. E não eram paisagem, nem eram arquitetura. Não haveria maior interesse se não fosse a pletora de artistas que começaram a praticar dentro de tal sensibilidade. Os pólos negativos poderiam ser traduzidos positivamente: não-paisagem = arquitetura / não-arquitetura = paisagem. Através de vários movimentos de significações opostas, ela ensaia, pelo avesso semiótico das ações, não uma nova definição para escultura em si, mas ao invés reconhece que tal produção significa simplesmente uma expansão da atividade escultórica, e que agora incluiria no campo da escultura as seguintes práticas abertas: construções em locais específicos, locais específicos marcados e estruturas axiomáticas.

O campo ampliado é então gerado pela problematização de uma série de opostos entre os quais a categoria moderna escultura é suspendida. Tão logo isso ocorra, tão logo se possa pensar dentro desta expansão, existem, logicamente, três outras categorias visualizadas [construções em locais específicos, locais específicos

\footnotetext{
${ }^{97}$ Em entrevista a Caco Xavier e grupo. Disponível em: <http://www.casadobruxo.com.br/poesia/f/fgullarent.htm>. Acessado em: 14 de julho de 2010.

${ }^{98}$ Ver Rosalind Krauss, "Sculpture in the Expanded Field", em H. Foster, The Anti-Aesthetic: Essays on Postmodern Culture, pp. 36-38, tradução nossa. No ensaio Krauss descreve com detalhes como baseou a sua lógica na matemática do grupo Klein, chegando à conclusão de que uma nova complexidade estética tomava conta das novas relações entre escultura, paisagem e arquitetura.
} 
marcados e estruturas axiomáticas], todas elas uma condição em si do campo expandido, mas nenhuma delas necessariamente assimiláveis como escultura. Como vemos, escultura não é mais o meio termo privilegiado de duas outras coisas que não é. Escultura é então um termo na periferia de um campo onde existem possibilidades diferentemente estruturadas. ${ }^{99}$

Este espaço-entre que Krauss localiza caracteriza o momento onde praiapaisagem frutifica. Poderíamos até considerar que praiapaisagem é então um termo na periferia de um campo onde existem possibilidades diferentemente estruturadas - não-paisagem = arquitetura / não-arquitetura = paisagem. Esta condição de suspensão direciona aos novos espaços públicos, pois não mais definidos por elementos predeterminados e fixos permitem a constante invenção da sua configuração e ocupação, exatamente como o processo de evolução da escultura transformando-se a partir do objeto isolado, contemplativo e glorificado. Também em suspensão, a escultura se abre e constrói dialéticas possíveis com a outras situações. Baseado em observações mais recentes, incluindo as teorias em torno das estéticas relacionais de Nicolas Bourriaud, Adrian Blackwell especula que as ampliações de Krauss podem ser ainda mais ampliadas, distendidas. Blackwell vai além e inclui - como parte de uma matriz que ensaia ser totalmente inclusiva - performance, performance cotidiana, e espaços teatrais. ${ }^{100}$ Blackwell argumenta que a influência de mídias como vídeo e televisão nos circuitos artísticos, e as possibilidades associadas a estas, como a temporalidade e novos potenciais de representação motivaram artistas para o campo da participação e engajamento, propondo invenções as quais consideram as relações sociais como obra de arte, e não somente os objetos.

Se a performance do dia-a-dia ganha força em relação às oficiosas artes dos museus como contraponto à desestabilização da escultura nas três últimas décadas, não estaríamos aqui reconhecendo novamente a deambulação e as sensibilidades situacionistas como prova e poder de uma nova era, como ponto crítico fulminante às acelerações hipertensas do capitalismo desmesurado da nossa passagem de século? Viemos e voltamos - seria então a continuação de uma caminhada iniciada pela modernidade de Baudelaire?

Quantas outras modernidades podemos delinear a partir de todas as transformações que o objeto sofreu desde o autor de Spleen? O que o quadro pós-estruturalista promoveu foi

\footnotetext{
${ }^{99}$ Idem, p. 38.

${ }^{100}$ Adrian Blackwell, "Not Architecture Not Performance: Reworking the Expanded Field". In Jen Budney e Adrian Blackwell, Unboxed: Engagements in Social Space. Ottawa: Gallery 101, 2005, pp. 1729.
} 
um questionamento mais rigoroso das relações, quaisquer relações — de poder, de participação, dialéticas e relações espaciais. Os artistas sempre se moveram na direção das sociedades e suas idéias, buscando mais do que uma simples tradução dos movimentos sociais, culturais, mas a compreensão mais profunda das complexidades que governam uma cultura. Mesmo que vivamos num tempo em que as rupturas radicais se apresentam mais tênues, imperceptíveis ou até ausentes, e as atitudes individuais se fragmentam e multiplicam, tornando quase impossível a categorização e classificação dos fenômenos. O sentido de vanguarda resvala num equívoco histórico e reavalia-se não mais em relação aos âmbitos individuais, aos desejos internalizados, mas em relação a um senso coletivo de relevância além do exclusivamente estético - portanto social. ${ }^{101}$

No percurso destas procuras a cidade, a metrópole do século 20, foi o local e o ator principal de tais mudanças, engendrando um vai-e-volta constante entre o dentro e fora. Quase que habitando permanentemente o divã do analista, as forças artísticas questionaram o valor e o papel da obra de arte e resistiram o máximo possível às seduções capitalistas que regeram o assustador crescimento da arte como veículo de comunicação e comodidade neste período. Na simples figura do artista flâneur, ou aquele que sai do ateliê para ver o mundo lá fora poderíamos resumir este gesto - partir para um outro território. Se por um lado mapeamos mais uma atitude do que uma sequencia de eventos e objetos, fica claro que as relações entre arte e arquitetura assumiram uma importância além do simples ilustrativo para conceber de fato um gênero artístico, que, por pura sorte, não recebeu um nome, ou um título, escapando assim de aniquilar-se nos anais da história da arte. A falta de uma nomenclatura para determinar estas dinâmicas é o que as mantém em aberto. Neste contexto é que praiapaisagem propõe um kit de articulações para o espaço público informada pelo processo delirante das artes dos últimos cinco decênios, pois é a partir dos processos artísticos que podemos identificar outras possibilidades de propor um novo espaço, pois na própria compreensão destes processos que o espaço em si é discutido e desafiado para além das instrumentalidades do poder e do controle das tecnocracias. As práticas artísticas ainda possuem a capacidade crítica de apontar novos rumos e de propor novas possibilidades, influenciando os seus próprios processos e a evolução em outras áreas de conhecimento.

${ }^{101}$ Nota-se o sucesso das mídias sociais entre as novas gerações. 


\title{
6_EPISTEMOLOGIA DA SUPERFÍCIE: DO OBJETO PARA A PRAIA
}

\begin{abstract}
A palavra superfície não pode deixar de evocar o que está sob dela, uma palavra contingente, inseparavelmente ligada ao seu oposto, a coisa da qual ela faz parte, impossível com os seus antônimos: interior, profundo, completo, sólido, cobertura, afundamento. É a superfície de alguma coisa, e o que está abaixo desta superfície: a superfície de uma pintura, a superfície da água, a superfície do texto, superfície do significado, a pavimentação de uma rua, a gramática de superfície de Wittgenstein e a sua gramática profunda. ${ }^{102}$
\end{abstract}

Em uma fotografia tirada pelo meu pai, em 1967, eu, a minha irmã e dois primos se encontram na rampa de acesso do Teatro Nacional de Brasília, projeto de Oscar Niemeyer, e com o reconhecido tratamento de fachada de Athos Bulcão, Relevo em concreto. O que altera a imagem é que a câmera foi girada para fora do seu eixo normal para que a margem do visor retangular acompanhasse o plano inclinado da fachada do teatro, alterando perceptivamente a posição horizontal das quatro crianças, agora inclinadas, sugerindo que talvez estivessem desestabilizadas dos seus eixos gravitacionais. Meus primos “se seguram” respectivamente nas coxas e na cintura, e minha irmã "se segura" pelas costas, talvez cansados pela escalada. Eu, com os olhos fixos na câmera, de calças escuras e ereto, sou o único que não se apóia no próprio corpo, depositando ao invés crédito irrestrito na arquitetura da rampa de acesso.

Vários aspectos emergem da imagem: o centro de gravidade foi desviado, pelo menos perceptivamente para aquele que a observa, fazendo os corpos parecerem inclinados; existe uma clara co-dependência dos corpos em relação à arquitetura: será a arquitetura que serve como pedestal para o corpo, ou são as presenças dos corpos que a justificam? O plano inclinado da fachada e o relevo de Bulcão proporcionam uma consonância, adjacências interdependentes de qualidade mítica, uma coisa de pirâmide, atemporal, apontando para uma síntese íntegra entre tempo e espaço. A superfície estendida de Bulcão, adaptada à arquitetura de Niemeyer, cobrindo a fachada até os limites do edifício, traduz arte em arquitetura sem um limite, compondo um código único, até de forma mais persuasiva que os seus murais e trabalhos em superfícies lisas (azulejos), e talvez pela protuberância geométrica que elegeu, Relevo em concreto torna-se mais espaço e menos imagem, distanciando-se da representação ao construir uma relação intrínseca com a arquitetura.

${ }^{102}$ Christa Robbins, "Surface", Chicago: The Chicago School of Media Theory (Keywords), inverno de 2002. Disponível em: <http://lucian.uchicago.edu/blogs/mediatheory/keywords/surface>. Acesso: 22 de maio de 2010, tradução nossa. 


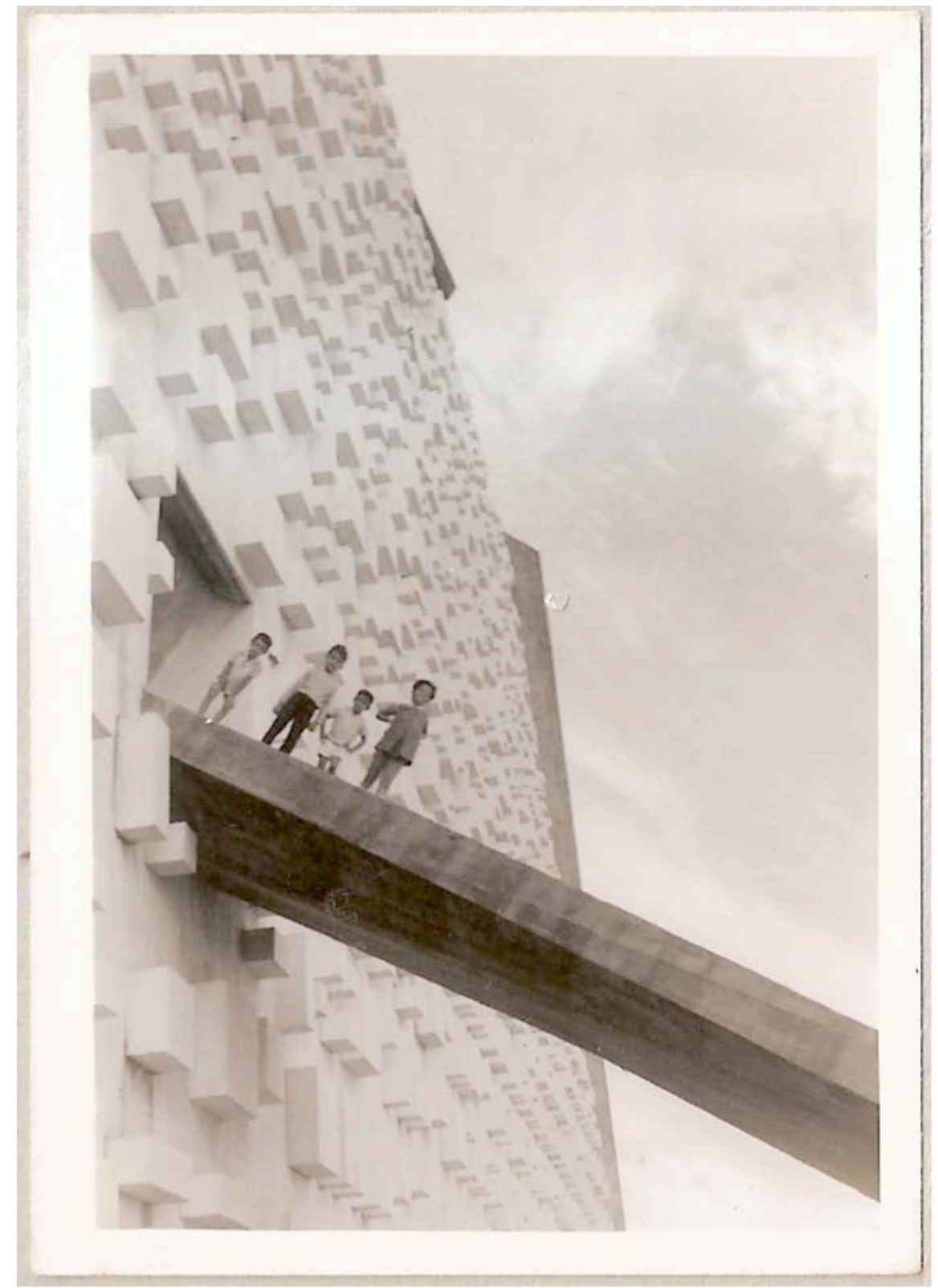

Minha irmã, meus primos e eu no Teatro Nacional de Brasília (1967)

Escultura como imagem? O que se olha? Uma escultura habitando a fachada do edifício? A arquitetura como depositário de uma obra de arte, ou como composição uníssona, sem distinção entre uma e outra? No momento da imagem intuitivamente apreendi os sentidos daquele espaço as suas complexas potencialidades no meu inconsciente, naquela minha própria pré-história, e então esta zona indefinida entre a prática do artista e do arquiteto era plantada. O gênese desta experiência forma a percepção para a identificação de praiapaisagem: a partir de uma superfície incomum encontra-se uma nova experiência, tornado a superfície viva e exuberante, imaginando uma vida a partir do objeto. A minha primeira memória foi, na verdade, a de um evento: como não é de se duvidar para um 
menino, imaginei-me escalando esta mesma superfície. A memória do evento é tão forte quanto a imagem. Representação e experiência marcam referências primordiais.

Independente de uma leitura autobiográfica, mesmo legitimado pela experiência pessoal, um breve mapeamento desta "superfície estendida", a partir da sua identificação original com a escultura, e da constatação que o discurso sobre o fenômeno-superfície em arte e arquitetura ${ }^{103}$, organize a matriz fundadora dos procedimentos de praiapaisagem. O fenômeno-superfície em arte e arquitetura serve como uma referencia de experiência pessoal apontando para a impossibilidade de disjunção entre teoria e prática. Neste caso específico caminhamos o olhar para a praia por esta ser essencialmente uma superfície ocupada, uma superfície de experiências complexas, mas manifestada fisicamente através de um desenho.

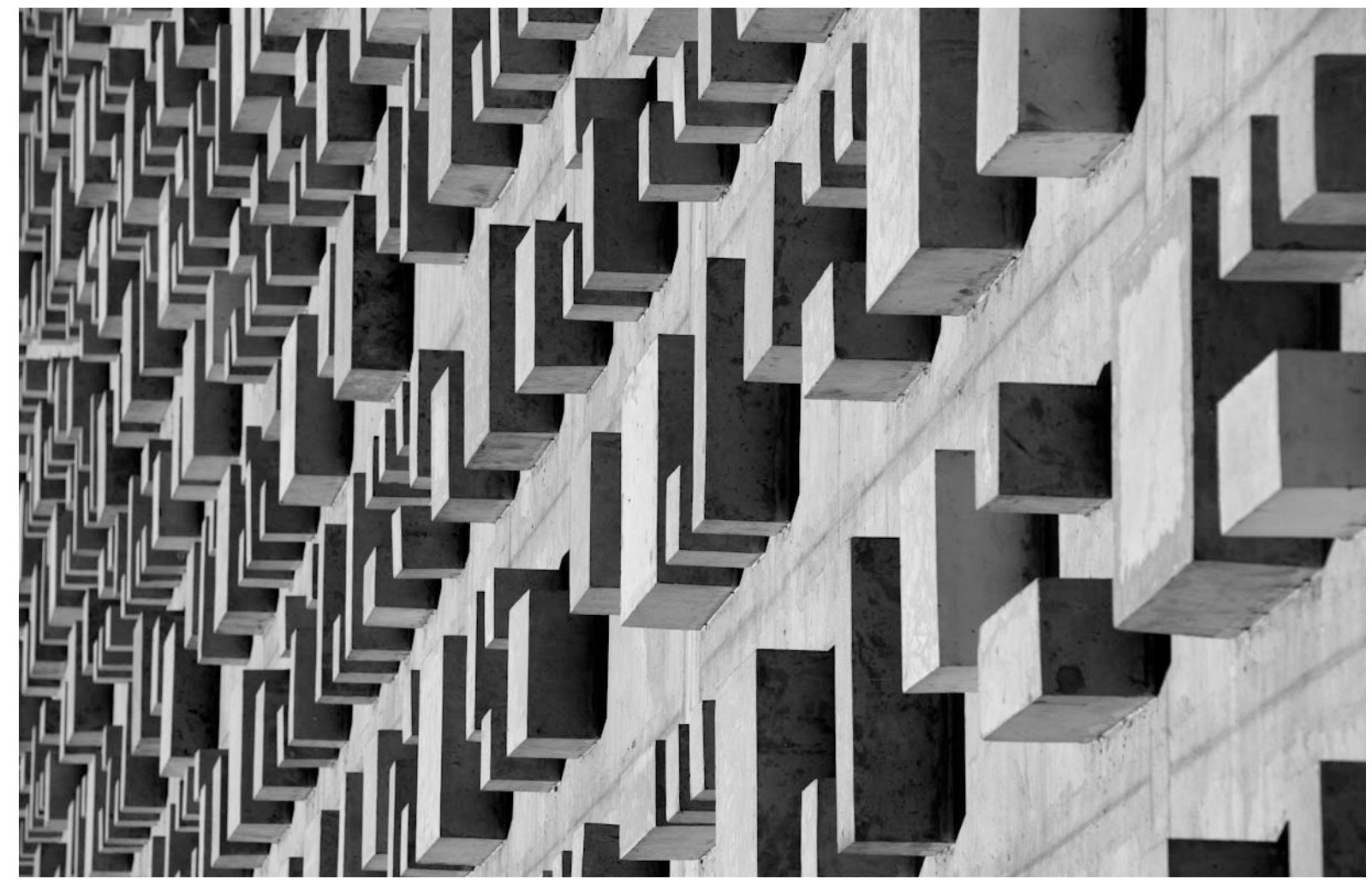

Athos Bulcão, Relevo em concreto, Teatro Nacional de Brasília (1966)

\footnotetext{
${ }^{103}$ De acordo com Franklin Leopoldo e Silva, fenomenologia "é aquilo que é dado ou aquilo que pode ser objeto de conhecimento a partir das estruturas cognitivas do sujeito. Vê-se portanto que o fenômeno é entendido como a realidade apreendida nos limites de uma perspectiva humana." Por sua vez esta perspectiva é formada não só pela racionalidade euclidiana, mas também pela compreensão perceptiva do mundo que envolve todos os sentidos dentro de um âmbito cultural e subjetivo.
} 


\section{I_A superfície do objeto}

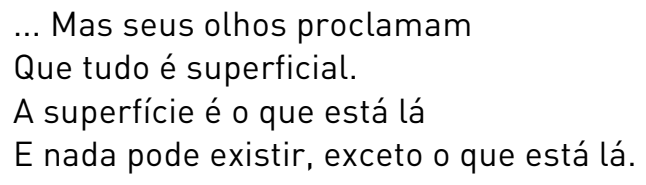

... E assim como não há palavras para a superfície, isto é, Não há palavras para dizer o que realmente é, o que não é Superficial, mas um núcleo visível, então não existe Um caminho para sair do problema entre pathos vs. experiência. ${ }^{104}$

- John Ashbery, Self Portrait in a Convex Mirror

$\mathrm{Na}$ experiência artística, tanto para aquele que observa uma obra de arte, quanto para aquele que a produz, um elemento se apresenta de imediato, mediando as relações perceptivas entre o objeto (a obra) e o sujeito (o observador ou o fazedor da obra). Da maneira mais evidente possível esse elemento imediato/mediador, a face, a cara, aquilo que se aborda primeiro, que se vê primeiro, de bate pronto, seja esse reconhecido ou não, é a sua superfície - toda obra de arte apresenta por conseguinte uma superfície. Ao mesmo tempo, por analogia, o fenômeno do primeiro contato com a superfície do objeto de arte pode ser associado com o primeiro momento do primeiro contato com a superfície da praia. A partir desta evidência inicial, não nos restringimos à pura e simples superfície física, mecânica do objeto, como Michael Fried se deteve, mas, dentro das possibilidades perceptivas de se pensar, experimentar e imaginar esta superfície e a sua natureza, ela desdobra-se em muitas classes e espécies, incluindo além do físico-material, o subjetivo, o psicológico, o político, o social, o cultural, enfim o sensorial. Não se esgotam nunca as suas possibilidades, pois no estímulo do primeiro contato forma-se uma relação individual, subjetiva. O "pensar-superfície" recebe sempre então mais uma camada, como se fosse um novo platô de Deleuze e Gattari na paisagem das multiplicidades e nas entradas do discurso contemporâneo. Se dirigimos o foco para a praia observamos também que as possibilidades de Fried podem se aplicar às perceptivas do pensar, experimentar e imaginar esta superfície praiana e a sua natureza, uma superfície que se desdobra em muitas classes e espécies.

Brian Massumi introduzindo Mil platôs em Prazeres da Filosofia caracteriza a estrutura do pensamento de Deleuze e Guattari quanto à sua escolha formal, quanto à imagem do

\footnotetext{
104 John Ashbery, Self Portrait in a Convex Mirror. New York: Penguin Books, 1990, p. 67.
} 
"platô", que assinala aqui para um outro sentido de superfície ${ }^{105}$ : “Ao invés de analisar o mundo em componentes discretos, reduzindo a sua pluralidade ao de identidade Única, e ordenando-os por categoria, eles somam um conjunto de circunstâncias diferentes, em um golpe esmagador. O conjunto sintetiza uma multiplicidade de elementos sem apagar a sua heterogeneidade ou sem dificultar o seu potencial para a reorganização futura (ao contrário). O modus operandi do pensamento nômade é a afirmação, mesmo quando seu objeto é um negativo aparente. Força não deve ser confundida com o poder. Força chega de fora para quebrar as restrições e abrir novos horizontes. Poder constrói paredes." ${ }^{106}$ A nova superfície então não pode ser reduzida a uma única espécie. Além de apresentar-se múltipla é dentro desta multiplicidade que o jogo objeto-sujeito cria forma. O objeto é introduzido à apreciação, encenando a relação com o indivíduo, assim assumindo diferentes formas na consistência de uma única aparência (superficial) - uma forma e uma experiência para cada indivíduo que entra em contato com o objeto - , criando assim, no conjunto de todas as experiências um campo múltiplo e infinito de possibilidades. Tanto o objeto de arte quanto a praia se apresentam como obras abertas, tanto para o indivíduo quanto para o coletivo. É dentro do fenômeno do primeiro toque que humanamente procuramos o nosso contato mítico com o mundo, que se resume ao encontro do próprio ser. O primeiro contato com a praia refere-se ao primeiro momento na vida que vislumbramos o mar, ou ao momento exato em que pisamos a areia quente com os nossos pés desnudos. As condições da experiência artística e a experiência da praia encontram-se no âmbito do suprasensorial, onde o cerne da própria experiência transcende a lógica da razão expondo o corpo como uma totalidade, agora em profunda conexão com o espaço, com o mundo. A origem desta experiência se dá a partir da realidade crua do primeiro contato com a superfície do objeto.

As multiplicidades de ideias que constroem o paradigma moderno da superfície, especialmente em relação com a escultura e o espaço, ou a praia e o espaço, formam um novo corpo de relações, apontando à uma atualização, à uma nova relevância quanto à questão da superfície. Esta leitura, por falha ou mérito, não se restringe em olhar o objeto de arte em isolamento, mas sim em relação à experiência do indivíduo, menos objetiva e mais relacional,

\footnotetext{
${ }^{105}$ De acordo com Dicionário Houaiss o platô é uma "superfície plana e pouco espessa de qualquer coisa; aquilo que constitui uma tal superfície."

${ }^{106}$ Massumi, Brian. “The Pleasures of Philosophy”. In Gilles Deleuze e Félix Guattari, $A$ thousand plateaus: capitalism and schizophrenia. Minneapolis: University of Minnesota Press, 1987, p. xiii, tradução nossa.
} 
e no contexto da arquitetura e da cidade. A necessidade da construção de tais relações vem da predominância radical da condição-superfície em relação à obra, em relação ao espaço.

Aceitando o convite de Mondrian em Home-Street-City ${ }^{107}$ - retirar-se do espaço individual da casa para considerar a rua como evento totalizante da experiência estética - a “multiplicidade de elementos” a que Massumi alude não só sugere um procedimento para a construção do texto, com os seus segmentos separados conduzindo a uma certa organização, mas confrontando a qualidade típica da superfície da obra de arte. Na procura de uma ligação com um outro tipo de superfície, mais prosaica, urbana e cotidiana, chegamos à superfície da praia identificando-a como uma "superfície de multiplicidades heterogêneas". Então, a motivação não é a consideração da superfície como evento derradeiro, conclusivo e estático mas sim a construção de uma dinâmica e de uma estrutura de pensamento para se compreender o processo evolutivo do plano e a transposição para àquela superfície que considero soberana: a superfície da praia, e mais especificamente orientado aqui, a superfície da praia de Copacabana.

Para além da imanência do objeto, com sua nudez crua e provocadora, olhamos para a sua superfície utilizando-se também de artifícios fenomenológicos, da experiência subjetivoperceptiva, pois assim, ao invés de reduzir as possibilidades de leitura por referências de opinião ou teóricas, colocando-as somente por preceitos individualizantes, abrimos aqui uma conversa sobre a superfície em rumo a um campo indeterminado, em fluxo aberto, em relação às referências de outros, mas também quanto à praia, procurando assim uma possibilidade de arte-vida. Exploramos um fundamento que de tão aparente e frontal talvez esteja meio batido, relegado dos debates. A imagem da praia então vem para renovar e problematizar a questão da superfície, criando um desvio às tendências formais quando se olha isoladamente um objeto. Além do próprio campo, existe a dilatação e abertura de um sentido, constatando neste processo um caminho de potencialidade: a compreensão da superfície da praia a partir de preceitos, fenômenos e procedimentos artísticos em relação à escultura.

E por que superfície? Quais seriam as relações a partir deste elemento constitutivo da obra de arte, a sua superfície, que pode ser considerada ao mesmo tempo fenômeno físico e

\footnotetext{
${ }^{107}$ Texto originalmente publicado como Neo-Plasticisme: De Woning-De Straat-De Stad no periódico i10, em 1927.
} 
perceptivo? O quanto as qualidades superficiais, ou o caráter superficial ${ }^{108}$ da obra determinam as relações com o outro ${ }^{109}$ A superfície, como uma questão colocada no contexto da praia, reconhece os sentidos, as aproximações e os confrontamentos no âmbito social e cultural, quando as relações entre a superfície da obra de arte e os aspectos fundamentais da escultura moderna, apresentando e estabelecendo pontos de contato entre a produção tridimensional contemporânea e a arquitetura a partir do questionamento das relações entre a obra de arte e a superfície. Conceitualmente e fenomenologicamente estas questões se dirigem à praia. $\mathrm{O}$ paradigma do artista contemporâneo passa pela impossibilidade de negar a obra de arte em relação à própria vida. São muito poucos que não questionam este equivalente da modernidade: O que é a vida, não é tudo senão a própria obra de arte? O que é a arte a não ser a própria vida? O mesmo para os arquitetos e urbanistas: não podemos negar a cidade! Paralelamente posicionamos a dualidade arte-vida com superfície-espaço, tão bem sintetizada por Doug Aitken: “Tornei-me inquieto com a superfície plana da tela e assim o trabalho evoluiu gradualmente para o resto do espaço". ${ }^{110}$

Para Aitken a superfície plana da tela é primeiramente uma inquietude! Ao apresentarmos a superfície, a ideia num primeiro momento nos remete à fisicalidade da coisa, à sua materialidade, e por conseguinte, à sua provocação imediata, visual, tátil, palpável. Não consideramos aqui que a natureza daquilo que chamamos superfície se limite a hipóteses formais somente. A ideia de superfície implica por pressuposto uma interioridade, um fenômeno subterrâneo, subcutâneo, algo abaixo e além, remetendo àquilo que encontra-se primeiramente a um segundo plano não obviamente identificado, uma espessura.

As premissas envolvidas nas discussões em torno dos processos artísticos e da obra de arte vão além da leitura formal e disciplinar do objeto, artifício que tanto marcou a segunda metade do século XX. As teorias em torno do objeto de arte se pautavam pelo formalismo analítico de Clement Greenberg, Harold Rosenberg ou até mesmo Mário Pedrosa, quando do começo de carreira. Greenberg, com o seu axioma reducionista e amparado pela irrevogável

\footnotetext{
${ }^{108} 0$ entendimento comum do termo "superficial" impregna a nossa cultura mediática por várias frentes. Superficialidade, neste sentido, seria a capacidade das ideias e conceitos superficiais, sem "profundidade de consideração". Superficialidade existe como uma forma de cultura de massa, reduzindo uma ideia a um imediatismo consumista, irrefletido e leviano, de fácil e banal assimilação. 0 termo "superficial" aqui refere-se ao elemento constitutivo da obra de arte, relacionado à sua superfície. Fica aqui somente a ironia: superfície superficial?

1090 outro: aquele que está de fora da obra, mas se relacionando com ela: o artista, o observador, o visitante, o curador, o crítico, etc.

${ }^{110}$ Doug Aitken em Alpha
} 
conquista da pintura - a inscrição de marcas em uma superfície plana ${ }^{111}$ - sugeriu que a redução formal e definitiva da pintura, representada acima de tudo pelo legado de Jackson Pollock, restava apenas na consequência do gesto calculado do artista marcando a superfície da tela, ou seja, a pintura pela pintura. ${ }^{112}$ Mas não seria talvez a maior contribuição de Pollock, para além da imagem criada, a transferência do plano vertical da tela para o plano horizontal, com o corpo agora engajado no interior do trabalho ocasionado pelo efeito da gravidade e da compressão do gesto sobre a tela? Neste sentido as imagens criadas seriam, além de simples pictogramas, um campo mapeado da relação corpo-obra. Para Fried, rebatendo a Greenberg, a superfície extremamente enfatizada conduzia a obra de arte à uma objetidade e não à arte pura como Greenberg sugeria. Fried afirmava que "na medida em que todos os objetos têm a superfície, a consciência da superfície da escultura implica em sua objetidade, ameaçando-a qualificar ou atenuar o prejuízo alcançado pela objetidade opticamente." ${ }^{113}$ A herança da leitura formalista da escultura minimalista, relegado aqui à predominância visual do objeto, não havia se permitido passar pelo filtro do pós-estruturalismo, que depositou mais confiança nas mudanças radicais da linguagem via transformação da paisagem político-social. A visão mono-cêntrico-visual iria se desestabilizar para dar lugar a uma abordagem onde o fragmentado, o detalhe, e a multiplicidade encontrariam um lugar no discurso estético.

Os movimentos políticos marcantes dos anos 1960, como o Black Power, o Feminista, a Situacionista Internacional, o crescimento urbano exagerado, as transformações econômicosociais, o advento de novas tecnologias como a internet, a televisão a cabo e a telefonia celular acompanhado pelo crescente fluxo migratório e transporte intra-continental engendraram novos territórios globais de relações, incitados agora pelo pensamento pós-estruturalista. As redes intensas de trocas criadas por tais transformações, em altíssima velocidade, produzem novas complexidades e um novo caráter temporal gerando uma problematização radicalmente diferente das leituras formais e retraídas em torno da experiência artística das décadas

\footnotetext{
${ }^{111}$ Clement Greenberg, "The Crisis of the Easel Picture". In Art and Culture Critical Essays Boston: Beacon Press, 1961 pp.:154-157, tradução nossa.

112 Poderíamos indicar duas vertentes da discussão em torno da superfície: uma que se origina na passagem do quadro para o espaço, com a ruptura da moldura, então um processo localizado especificamente na história da pintura; e a outra vertente que se desenvolveu com a supressão da base na escultura e a sua passagem para o espaço. Mesmo que tais evoluções tenham se dado integralmente e simultaneamente como processos únicos e paralelos, nos detemos aqui no segundo processo: a superfície em relação à escultura.

${ }^{113}$ Michael Fried. Art and Objecthood. Artforum, junho de 1967, tradução nossa. Republicação em: Gregory Battcock [org.], Minimal Art: a Critical Anthology. New York: Penguin, 1968, pp. 116-147.
} 
anteriores. Tais fatores, disseminados agora em uma escala trans-territorial, suscitam mudanças importantes nas reações dialéticas, processo esse desenvolvido por críticos como Rosalind Krauss, Lucy Lippard, Suzanne Lacy, dentre outros, que reconstruíram a disciplina crítica para além dos aspectos formais da obra, abordando questões como processo e contexto, e favorecendo o artista acima dos conceitos.

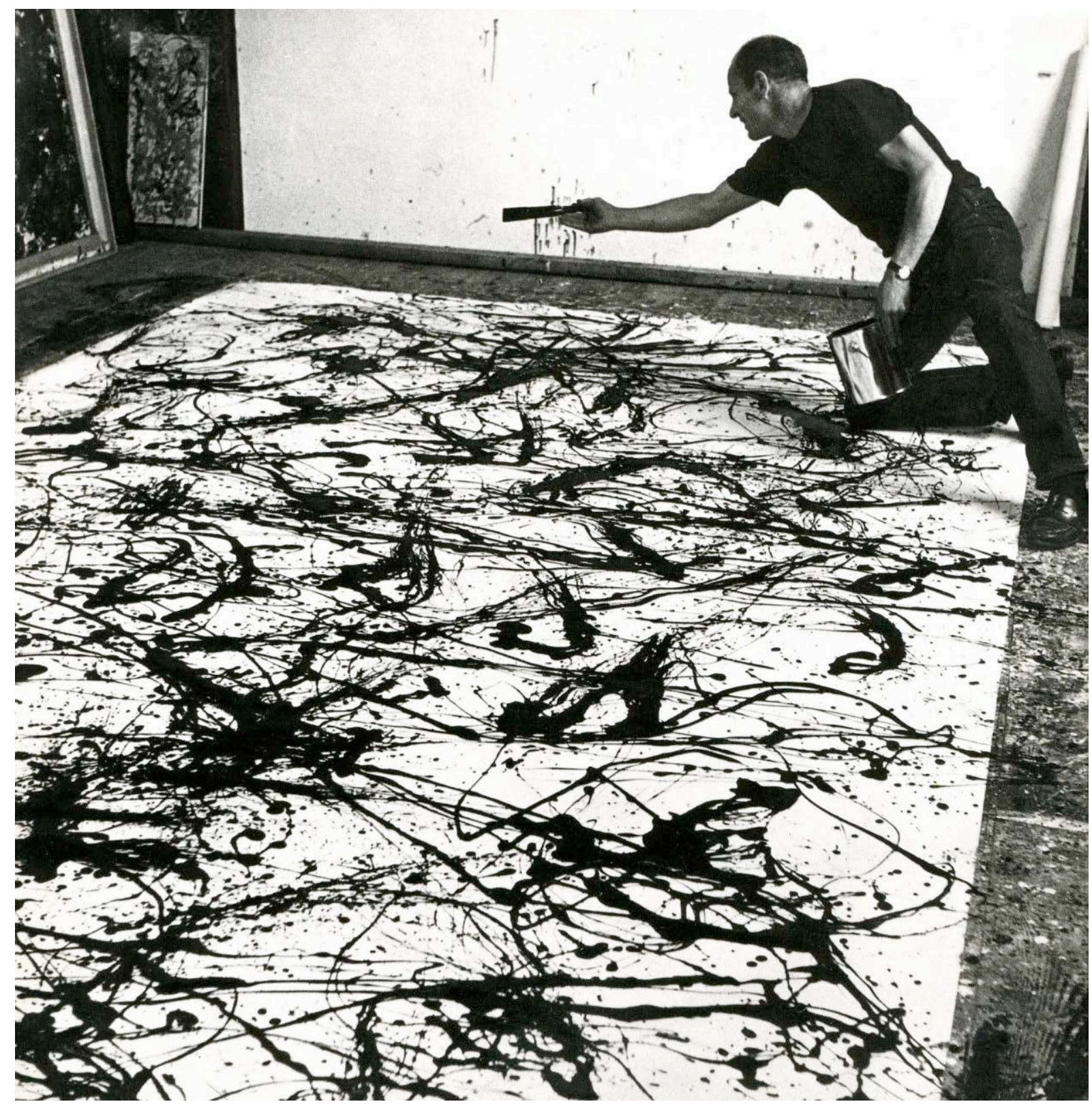

Jackson Pollock pintando 
Tais dialéticas críticas, ou até mesmo dualidades, reduziam as possibilidades de significações a tal ponto que condicionavam também a natureza da experiência artística. ${ }^{114}$ A meu ver existem tantas experiências quanto participantes das experiências, e os leques de possibilidades interpretativas estão tão abertos quanto às reações diante da obra ou da situação. Como resposta à predominante voz que ocupava as fontes de disseminação crítica da época houve talvez uma força muito maior que se expandiu a partir dos anos 1950, que foi o fato dos artistas terem assumido uma maior responsabilidade pela própria reflexão do trabalho. Tais fatores influenciadores determinaram uma abertura no discurso formal da arte, e por consequente, a maneira que os artistas, intuitivamente ou até diretamente, transformaram a natureza do objeto e da sua superfície para engajar novas questões. Ao invés de contestar aqui as diversas definições que a superfície possa ter na passagem da escultura para o espaço, propomos um mapeamento discursivo sobre a superfície em relação à escultura e das suas relações com o espaço, e por final, a sugestão para a construção de uma taxionomia que apontaria para a caracterização da superfície da praia como somatória de várias significações identificadas nesta trajetória. Se a praia pode ser considerada primordialmente como uma superfície, praiapaisagem amplia esta designação por aceitá-la na sua espessura, na sua dimensão total como espaço, como espaço-vida.

Na passagem da escultura para o espaço, espaço físico e de significação, Barnett Newman sintetizou o fenômeno físico-estrutural em escultura através do tráfego de cargas, da maneira em que elas viajam através do objeto até o solo, com o seu trabalho The Broken Obelisk (1963-67). Broken Obelisk se estende verticalmente por quase 8 metros, e é constituído por uma forma de obelisco interrompido na parte superior, e uma forma piramidal na sua base, na proporção de 1:4. Localizado de ponta cabeça e fraturado na sua extremidade mais alta o obelisco desce e encontra na sua parte inferior com o ápice de uma pirâmide, formando neste encontro o ponto de maior energia do trabalho. A pirâmide, quatro vezes mais larga que o obelisco na sua base, repousa sobre uma outra base reduzida, de alguns poucos centímetros maior que ela mesma, talvez aludindo ao fato de que este objeto, afinal das contas, se tratava de uma escultura, então necessitava de uma "base". Newman ofereceu o Broken Obelisk em homenagem a Martin Luther King, depois do seu assassinato, mas o momento onde estas

\footnotetext{
114 Os anos 1980 foram célebres na criação de grandes exposições com um caráter altamente marcado pela personalidade e decisiva identidade dos próprios curadores. Nos anos 1990, tal tendência abriu para apresentações conceitualmente e culturalmente mais múltiplas e diversas. A passagem entre estes dois universos distintos suspenderam as premissas totalizantes dos anos 1950.
} 
duas formas prototípicas se encontram não pode ser considerado apenas simbólico. As cargas da massa do aço corten começam a viajar predominantemente pelas superfícies externas do obelisco, e no momento que alcançam a parte inferior (na verdade o "topo" do obelisco) se concentram em um só ponto, o primeiro ponto de apoio. ${ }^{115}$ Neste momento todas as cargas são transferidas para o topo da pirâmide inferior. As cargas do obelisco se juntam às cargas da pirâmide, e em uma somatória de forças, obelisco + pirâmide, alcançam o solo. Um esperado segundo ponto de apoio não existe, pois, ao alcançar o solo as cargas são distribuídas "superficialmente", através de incontáveis pontos de contato entre a escultura e a sua base, e então ao solo. Este movimento de cargas - de fora para dentro > de dentro para fora / concêntrico > excêntrico - sinaliza para uma imagem sintetizante de que todas as forças do mundo, incluindo aquelas intrínsecas ao corpo, são inevitavelmente distribuídas ao solo de uma forma ou de outra. Simbolicamente o Broken Obelisk alude à uma nova monumentalidade pela imagem invertida do obelisco clássico, e reforçada pela homenagem de Newman a Martin Luther King, indicando assim um novo desvio das estruturas de poder.

Fenomenologicamente, no Broken Obelisk as energias são captadas e concentradas ao seu nível máximo para então serem distribuídas para além dos limites dos perímetros originais da estrutura que as gerou (o obelisco). Tal imagem assinala um novo direcionamento em escultura. $\mathrm{O}$ desvio gravitacional, a transferência do centro de gravidade do objeto para o solo, em sua dimensão formal e específica, aponta para dois elementos a serem considerados. O primeiro seria o aparecimento da superfície como artifício predominante mas não aparente, como elemento constitutivo da obra, mas não necessariamente como uma imagem, visível, e sim como fenômeno. A superfície a que me refiro não é evidentemente a tectônica, construída pela materialidade do aço corten, com suas cores e texturas, mas sim a superfície de transição das forças entre o objeto e o mundo. O outro dado a ser considerado seria em relação à sua monumentalidade: ao reivindicar uma nova relação entre escultura e monumento pela inversão da posição do obelisco tradicional, agora apresentado de ponta cabeça, homenageando o líder negro King, o Broken Obelisk de Newman oferece também uma nova relação entre objeto e observador, sugerindo que o domínio da experiência seja compartilhado para aquele que o observa, e não completamente controlado pela imposição do objeto.

\footnotetext{
${ }^{115}$ Tanto este detalhe quanto a utilização de formas universais - como o obelisco e a pirâmide sugerem leituras simbólicas do trabalho. No entanto são os fenômenos físico-estruturais que se aproximam com a pintura de Newman, que evitava referências simbólicas concentrando-se em espaço e cor.
} 


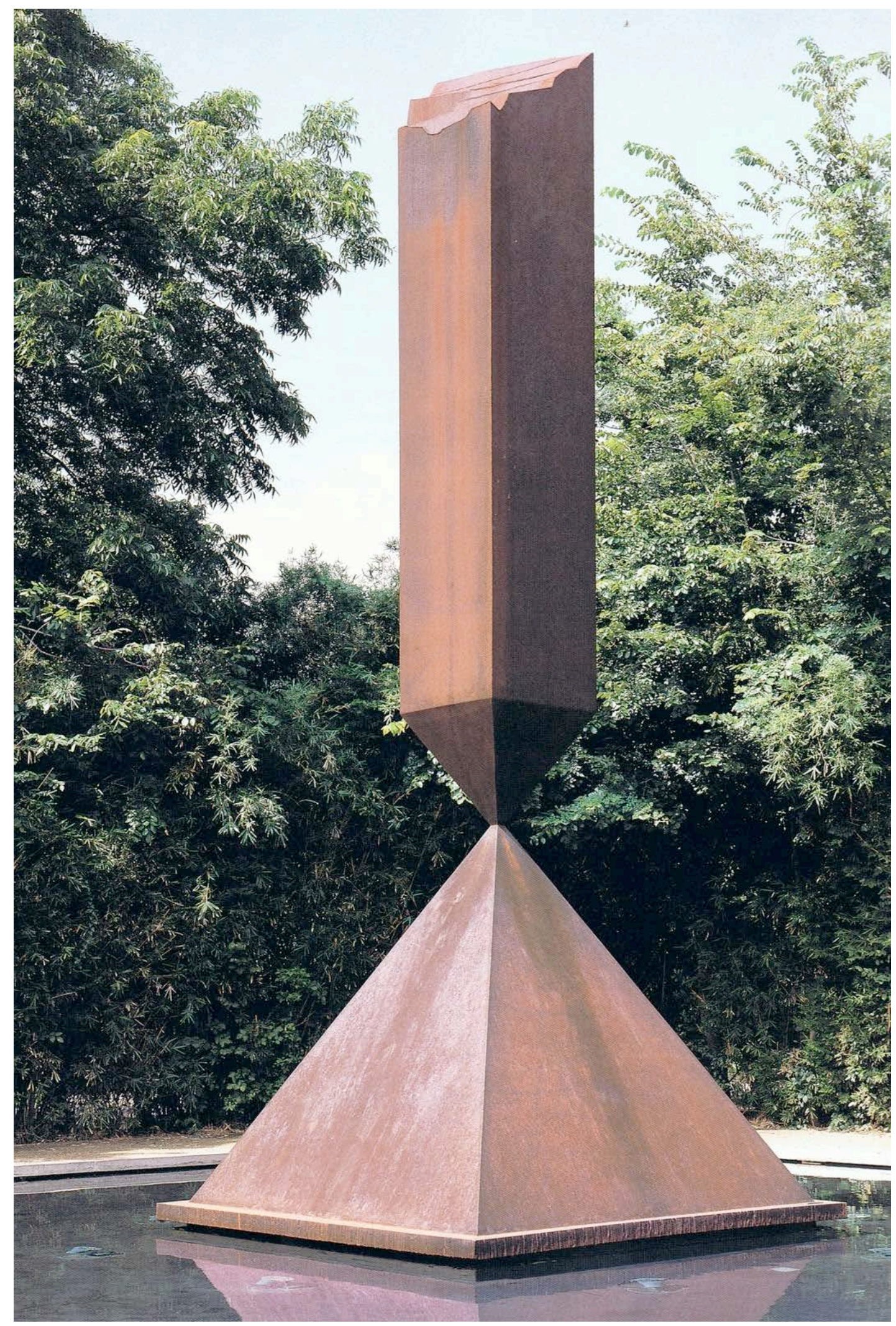

Barnett Newman, The Broken Obelisk (1963-67) 


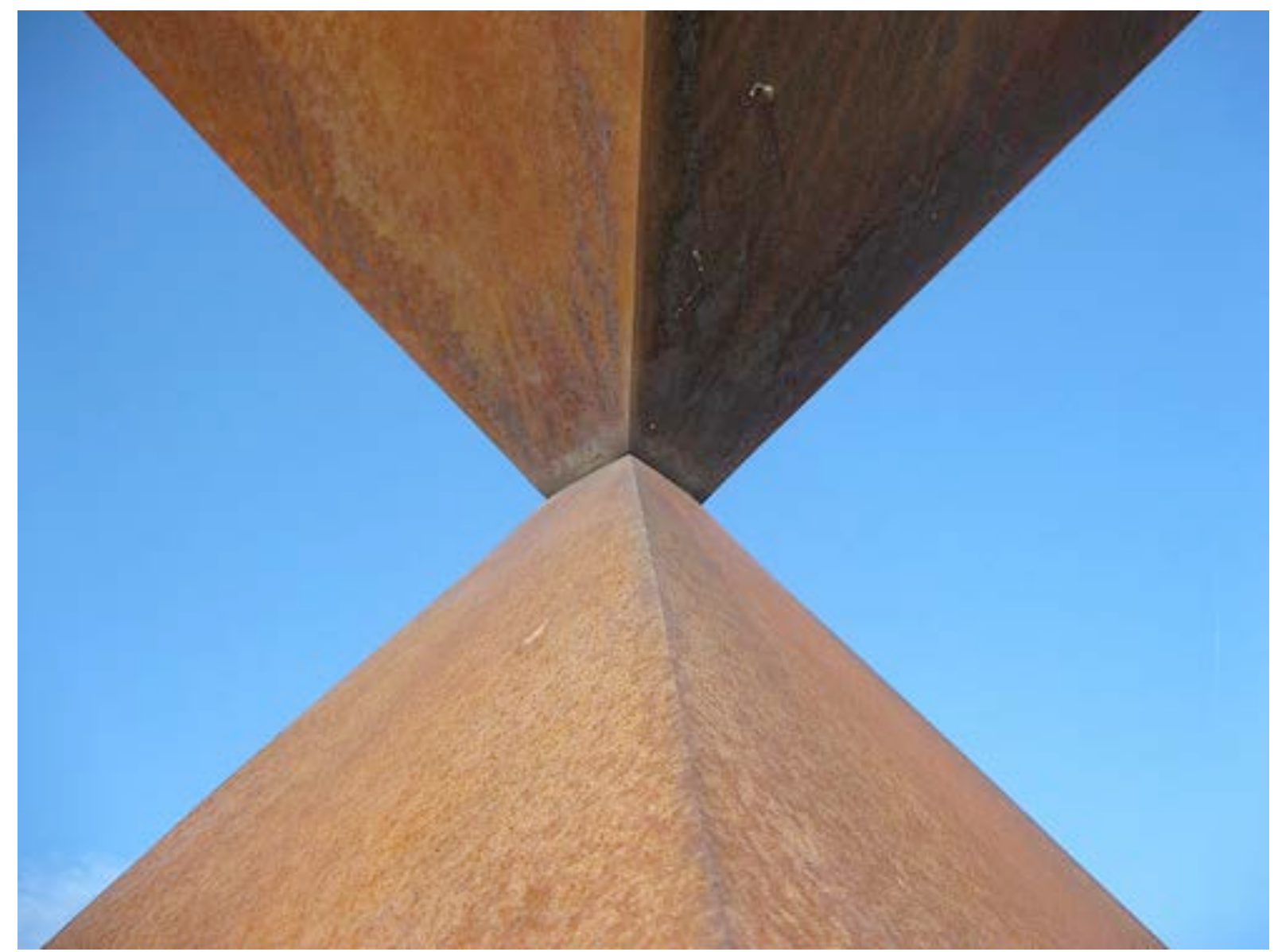

Barnett Newman, o ponto de apoio em The Broken Obelisk (1963-67)

Então, esta superfície estendida na base da pirâmide, distribuindo todas as forças do objeto, pode ser entendida também como uma metáfora de distribuição de controle e poder, não pelas dinâmicas políticas, mas pelas forças individualizantes do fenômeno dentro da experiência poética do mundo. Neste momento é que localizamos o potencial subversivo da arte, e reiterando Massumi: "Força não deve ser confundida com o poder. Força chega de fora para quebrar as restrições e abrir novos horizontes. Poder constrói paredes." Se o poder constrói paredes poderíamos então dizer que a arte as dissolve, abrindo a experiência para outras direções. Por analogia o fenômeno da praia possui um papel semelhante, mas agora na escala humana do corpo: a praia elimina as fronteiras, quebrando restrições e abrindo novos horizontes de relações, dilatando a experiência para múltiplas direções. 


\section{II_A superfície dura do objeto (o edifício)}

Essencialmente importante para Jackson Pollock, a gravidade para Richard Serra é talvez mais fundamental do que a própria matéria do aço corten. É através da gravidade que Serra negocia o contraponto para a sua escultura: para encontrar estabilidade do objeto é necessário uma geometria precisa evitando-se assim que o objeto tombe. É nesta medida geométrica precisa que Serra formula a relação entre as cargas viajantes. O centro de gravidade invisível controla a materialidade do aço e seu peso. Esta invisibilidade é perceptivamente desestabilizadora, mas é exatamente o que equilibra a massa e suas forças no espaço. Nas esculturas de Serra existe sempre a ilusão de desestabilidade. Essa percepção engaja o visitante no espaço e no seu movimento constante no entorno da obra tenta, mesmo que inconscientemente, achar o próprio ponto de gravidade, a sua localização individual no espaço. Esta procura é uma alusão à própria procura subjetiva no espaço. É aí que habita a energia central do seu trabalho.

Como um meio de classificar passo a passo as suas ações com o objeto, ele registra entre 1967 e 68, em "Compilação de uma lista de verbos: Ações para se relacionar com si mesmo", uma série de verbos delineando os procedimentos observados nos seus experimentos em ateliê. Fazem parte da lista algumas qualidades do objeto que, mesmo não caracterizados gramaticalmente como verbos, agem como tais nas suas fundamentais implicações em relação às questões que trabalhava: de tensão / de gravidade / de inércia / de equilíbrio / de força. Se Compilação evidencia uma tendência processual e performática característica dos anos 1960, ela também indica a preocupação estrutural de Serra, transpondo os limites da escultura para os limites da engenharia. Nesse momento, a relação entre verticalidade e horizontalidade no seu trabalho transforma-se em material essencial, pois para se recuperar uma qualidade sensorial que negocia a relação do objeto com o espaço e o observador a verticalidade se torna, como a gravidade, elemento-chave. Trabalhando em uníssono, a massa acumula as forças em uma verticalidade concentrada, demandando então uma geometria específica e uma série de relações estruturais e espaciais com a arquitetura do lugar e até com si mesmo, recuperando assim o próprio equilíbrio, o que é o caso da maioria dos trabalhos produzidos depois de Splashing [Espirrando]. Se Splashing (o derretimento de chumbo atirado no canto, no ponto de encontro entre o chão e a parede) representa a transição entre forças verticais para forças horizontais, a partir de trabalhos centrais como One Ton Prop (House of Cards) [Acessório de 
uma Tonelada (Castelo de Cartas)], de 1969, a verticalidade assume papel vital na progressão de seus experimentos.

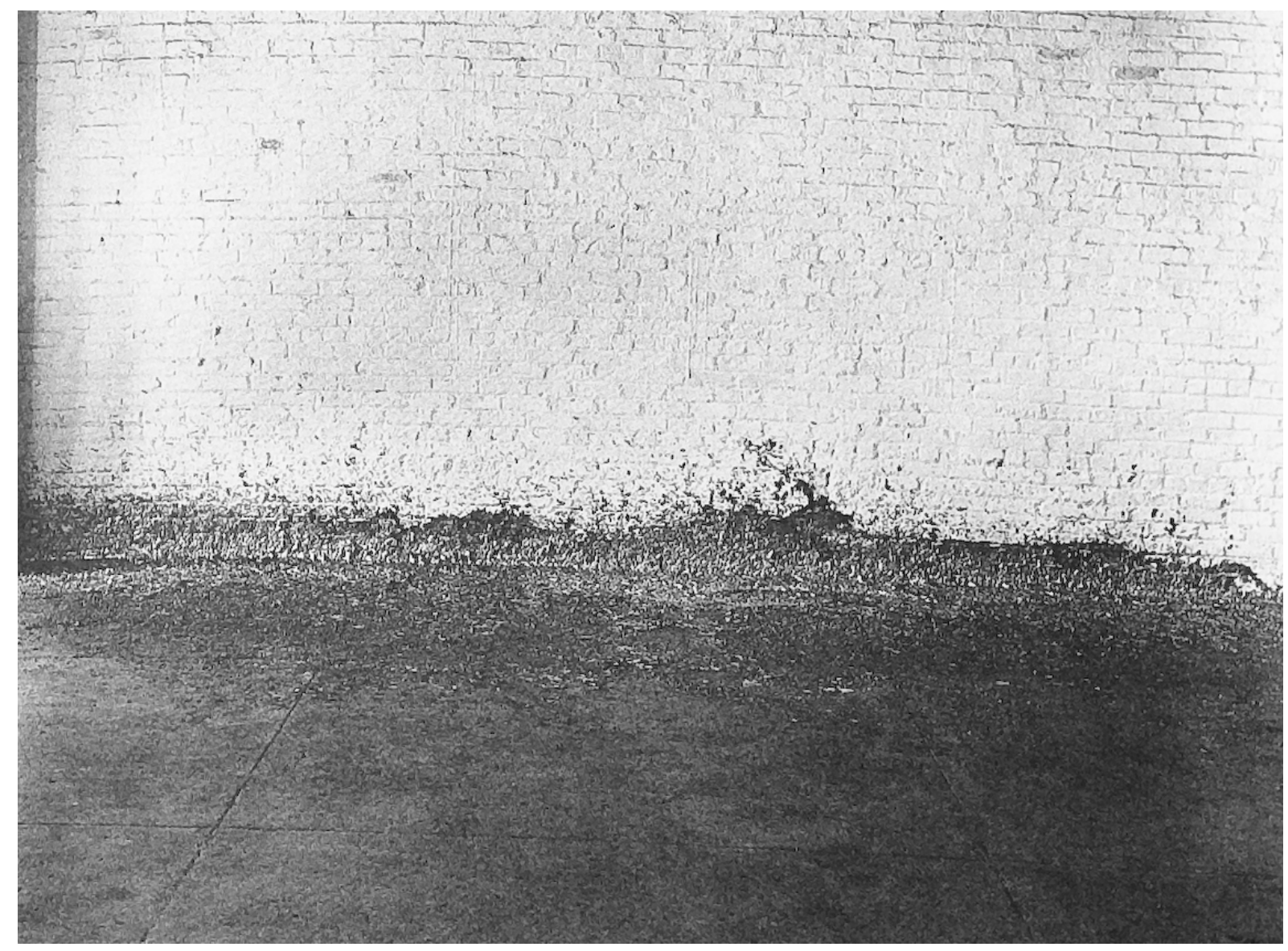

Richard Serra, Splashing (1968)

No sentido monumental, com a imposição do objeto em relação ao seu observador e em relação à sua presença no espaço público, o trabalho de Serra confirma a tradição da verticalidade como força maior da escultura tradicional. A diferença em Serra é que a imagem figurativa e o simbolismo consequente desaparece dando lugar à experiência perceptiva do objeto. Sem "ter o que procurar" visualmente dentro de uma suscetibilidade interpretativa, o observador é convidado a tomar uma posição diante do objeto abrindo uma negociação de muitas frentes: Vai cair? Não vai cair? O que representa? Posso tocar? Posso entrar? Posso encostar? Neste processo a superfície dura do trabalho assume um papel central pois, na experiência perceptiva da obra de arte, o corpo procura a sua relação com o objeto a partir de um processo de "escaneamento" constante, análogo talvez às sensações que se tem quando passamos ao lado de um edifício maior, reconhecendo intuitivamente a sua presença mas sem necessariamente estarmos conscientes da sua imagem. Esta provocação perceptiva no trabalho 
de Serra é reveladora desde One Ton Prop (1969) até Promenade (2010) ou nos seus trabalhos mais recentes, quase como um mantra: explorar o intercâmbio entre a arte, o lugar e o espectador, utilizando a larga escala, respondendo especificamente ao lugar peculiar da arquitetura onde o trabalho se encontra, relacionado ao espaço urbano e às configurações de diferentes paisagens. Mesmo que Serra resista às analogias da sua obra com a arquitetura, na sua essência ele constrói um diálogo constante entre a escultura e o edifício, entre a escultura e a paisagem. Da mesma maneira em que Serra considera fatores estruturais e contextuais, assim faz o arquiteto em relação ao edifício. É como se Serra extraísse a essência fenomenológica da arquitetura na sua escultura: escala, presença, peso, materialidade, gravidade, e estrutura, mas tudo isso despossuído de programa ou aparente utilidade.

\section{III_A superfície mole do objeto (a praia)}

O que ocorre quando o paradigma da verticalidade é quebrado? De uma geração posterior, mas criado dentro de um contexto onde a monumentalidade e a verticalidade são ícones incontestáveis, o artista mexicano Gabriel Orozco se faz utilizar da horizontalidade como estratégia semântica no processo de repensar o objeto-escultura. Gabriel Orozco é filho de Mario Orozco Rivera, pintor muralista e professor de arte na Universidade Veracruzana. Quando Orozco tinha seis anos, a família mudou-se para o bairro de San Angel da Cidade do México para que seu pai pudesse trabalhar com o artista David Alfaro Siqueiros em vários projetos murais. Seu pai o levava junto às exposições de museus e para trabalhar com ele onde Gabriel ouviu muitas conversas sobre arte e política. Mesmo exposto à monumentalidade e verticalidade da obra paterna Orozco elegeu a horizontalidade como intuição constitutiva da sua obra. São inúmeros os trabalhos que se servem na horizontalidade na obra de Orozco. Em Orozco a horizontalidade é simplesmente encontrada, como é o caso de Home Run (1993), onde laranjas foram colocadas nos peitoris dos edifícios vizinhos ao Museu de Arte Moderna de Nova York; ou Turista Maluco (1991), onde laranjas foram espalhadas nas barracas vazias de uma feira no Brasil; em Extensions of Reflection (1992), que são marcas circulares feitas com pneu de bicicleta a partir de uma poça de água na rua; ou em Piedra que cede (1992), onde uma bola de plasticina de igual peso ao corpo do artista é rolada pelas ruas da cidade recebendo assim as marcas e resíduos da cidade. A horizontalidade é também projetada, especialmente em um grupo de trabalhos que se utilizam da mesa como superfície de re- 
significação. É o caso de Mesa de bilhar oval (1996), onde um dispositivo redireciona a bola em jogo contrariando a vontade do jogador; Mesa de ping-pong (1998), com quatro extensões permitindo o jogo para quatro jogadores, que inclui um laguinho com plantas no meio; ou Horses Running Endlessly (Cavalos Correndo sem Parar), de 1995, um tabuleiro de xadrez em que apenas peças de cavalos participam do jogo. Não só Orozco se utiliza da horizontalidade como aparato da obra, mas a obra em si, ou a ação, é produzida por uma referência direta ao cotidiano ou a alguma brincadeira ordinária.

Mas é Areia sobre a mesa (1992) que Orozco mais tipifica a apropriação de uma superfície horizontal como determinante da obra. Uma mesa, aparentemente "achada” em uma superfície arenosa, provavelmente uma praia, é coberta no seu topo por uma quantidade de areia suficiente para preencher a sua superfície ao máximo. O que define a forma piramidal da areia é exatamente a resistência de compressão entre os seus grãos, forçando, pela gravidade, o restante para fora da mesa.

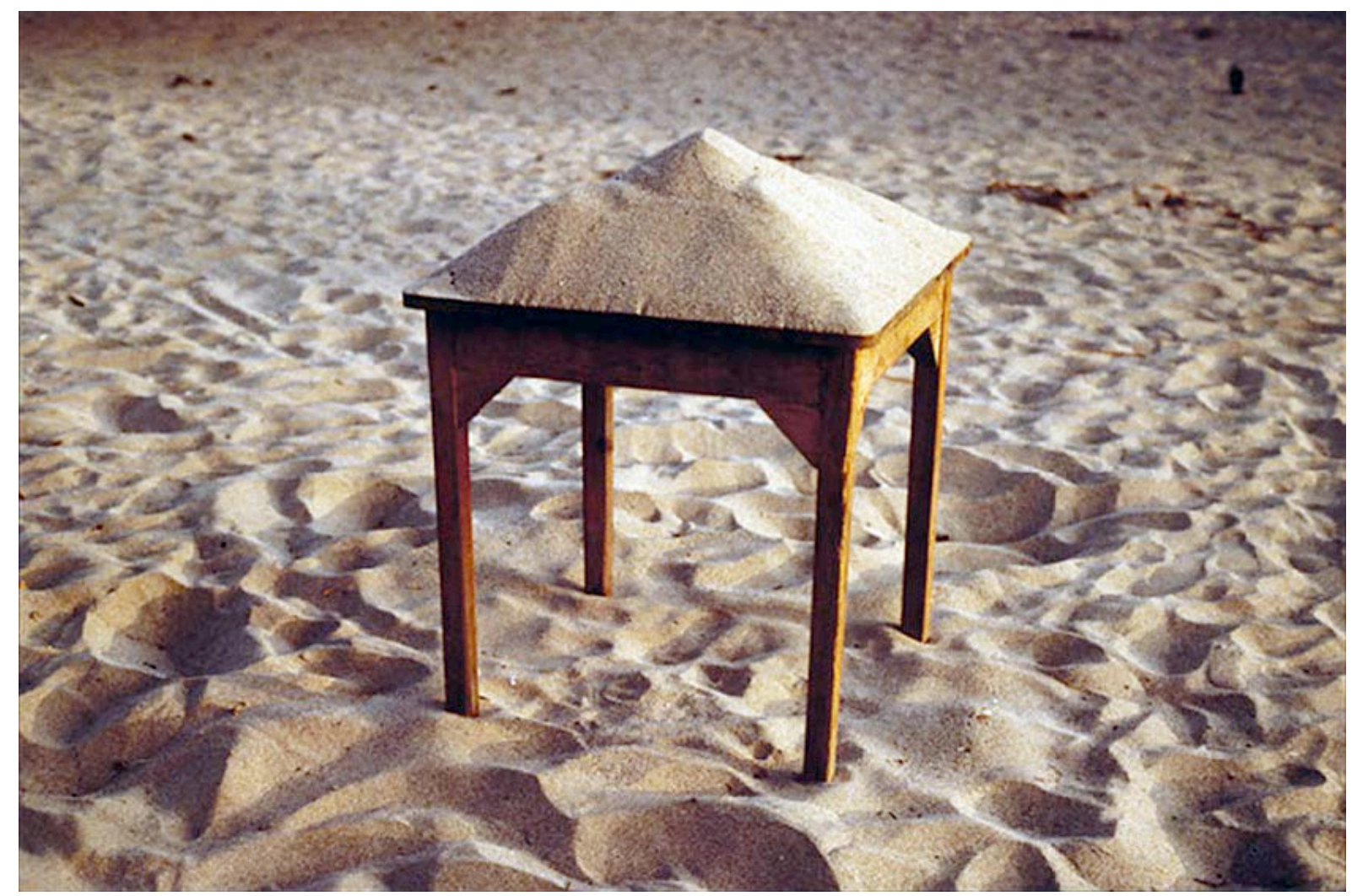

Gabriel Orozco, Areia sobre a mesa (1992)

A atitude de Areia sobre a mesa é diametralmente oposta à posição de Richard Serra em relação à escultura. Aqui o objeto é encontrado no seu "ambiente natural", e não 
intencionalmente posto lá. A materialidade é acidental e o que sustenta a poética do trabalho é a combinação areia/mesa, enquanto que em Serra o artista decide pelo material (aço corten). O tempo em Orozco é efêmero, frágil e fugaz, em Serra o tempo é permanente e estável. Em Serra a verticalidade é o que sustenta o âmago do trabalho, conceitual e fisicamente, mas em Areia sobre a mesa é a horizontalidade que ampara a intenção da obra. Se por um lado temos um caráter "peso-pesado” em Richard Serra, por outro a caracterização de uma "leveza do toque" (lightness of touch) que Guy Brett tão bem elucida em "Between Work and World" inferindo uma nova direção em escultura:

\begin{abstract}
O sol quente, as impressões aleatórias dos pés das pessoas na areia, dá a inflexão poética do 'mundo', 'vida', e que nos permite internalizar a imagem de uma maneira diferente. Especificamente, parece que cortamos o atalho da instituição de arte, para o trabalho ser colocado diretamente na área de experiência comum que todos partilhamos. A 'leveza do toque' por Orozco que produz isso é o que especialmente apreciamos.
\end{abstract}

Aqui a teoria da "leveza do toque" de Brett relaciona-se com a noção de weak architecture (arquitetura fraca) de Ignasi de Solà-Morales, uma classificação estética pouco explorada. Para Solà-Morales arquitetura fraca demonstra "a força da fraqueza, que a força da arte e da arquitetura são capazes de produzir precisamente quando adotam uma postura não agressiva e dominadora, mas tangencial e fraca." 116 A noção de arquitetura fraca de SolàMorales ajuda a tipificar a distinção entre Serra e Orozco. Os confrontos entre estes dois corpos de obras indicam maneiras paradoxais de transformação da força de gravidade em experiências distintas. Esta imagem aparentemente contraditória esclarece a passagem da predominância da verticalidade para a horizontalidade, esclarecendo uma relação específica com o espaço. No caso de Serra ela define o controle total do artista sobre a obra e da confirmação das acepções e artifícios institucionais de validação do objeto de arte. No caso de Orozco ela designa a suspensão do objeto enquanto arte, enfatizando a experiência poética do objeto no seu lugar, e trazendo a existência cotidiana para dentro da esfera artística. $\mathrm{O}$ controle total do artista sobre a obra em Serra é análogo ao controle total do arquiteto sobre o edifício. A suspensão do objeto, a ênfase na experiência poética objeto no seu lugar e a existência cotidiana da experiência em Orozco aproxima-se com a condição suspensa da paisagem da praia, mole e aberta às imprevisibilidades da vida. Quando da presença de um

\footnotetext{
${ }^{116}$ Ignasi de Solà-Morales. “Weak Architecture”, in Differences: Topographies in Contemporary Architecture. Cambridege, Mass.: The MIT Press, 1999. P. 71, tradução nossa.
} 
objeto a tendência é a contemplação dele mesmo. Quando da habitação de uma superfície como a praia, mole e convidativa, observamos o mundo de dentro para fora: o objeto é aniquilado em favor da experiência.

\section{IV_Superfície-mundo: a manifestação de uma outra vida}

Por volta da mesma época em que Newman criou Broken Obelisk, um grupo de jovens artistas experimentava com novos materiais e atitudes diferentes dentro do processo de feitura da obra. Dentre eles, Carl Andre despontou com um corpo de obras que fazia parte do mesmo léxico, isto é, trabalhos em que a utilização e a pesquisa de novos materiais e processos de fabricação industriais eram centrais. Outras estratégias marcaram o trabalho de Andre, incluindo o seu claro interesse pela "gravidade como material" e o engajamento do chão da galeria como suporte e expansão da obra. A grelha e a sequência repetitiva indicavam as lógicas e os processos reguladores, sugestivos da produção industrial, distanciando assim o objeto de qualquer ideia de expressividade subjetiva através do gesto autoral do artista. Tais preceitos fundamentavam também a organização destes objetos no espaço.

Depois de um longo período de reflexão no começo dos anos 1960, Andre voltou a produzir e em 1966 criou Lever (Alavanca), que fez parte da célebre exposição do mesmo ano de Kynaston McShine no Jewish Museum de Nova York, Primary Structures: Younger American and Bristish Sculptors. Lever constituía-se de uma fila de mais de cem tijolos cerâmicos encostados e alinhados um ao outro, perpendiculares à parede da galeria. Aqui a presença do objeto permanecia saliente pela espessura regular dos tijolos, e pela sua contiguidade à parede, consequentemente apresentando uma frontalidade em relação ao visitante. Mas foi depois de Lever, durante 1968 ou 69, que Andre começou a utilizar chapas metálicas cortadas. 144 Lead Square (144 Quadrados de chumbo) de 1969, simulava "um novo chão da galeria", um novo território no espaço expositivo mas que agora se destacava da parede, permitindo assim ao visitante se aproximar do trabalho em qualquer ponto e até pisálo e atravessá-lo caminhando. Aqui, a superfície de energia acumulada, distribuída e transferida, identificada na base da pirâmide em Broken Obelisk, se iguala ao trabalho em si tudo é superfície - transformando-se simultaneamente no solo da galeria e no plano da obra. E o visitante, que agora ocupa esta obra-superfície com o próprio corpo (à la Jackson 
Pollock), acaba fazendo parte integral da obra e da arquitetura da galeria. ${ }^{117}$

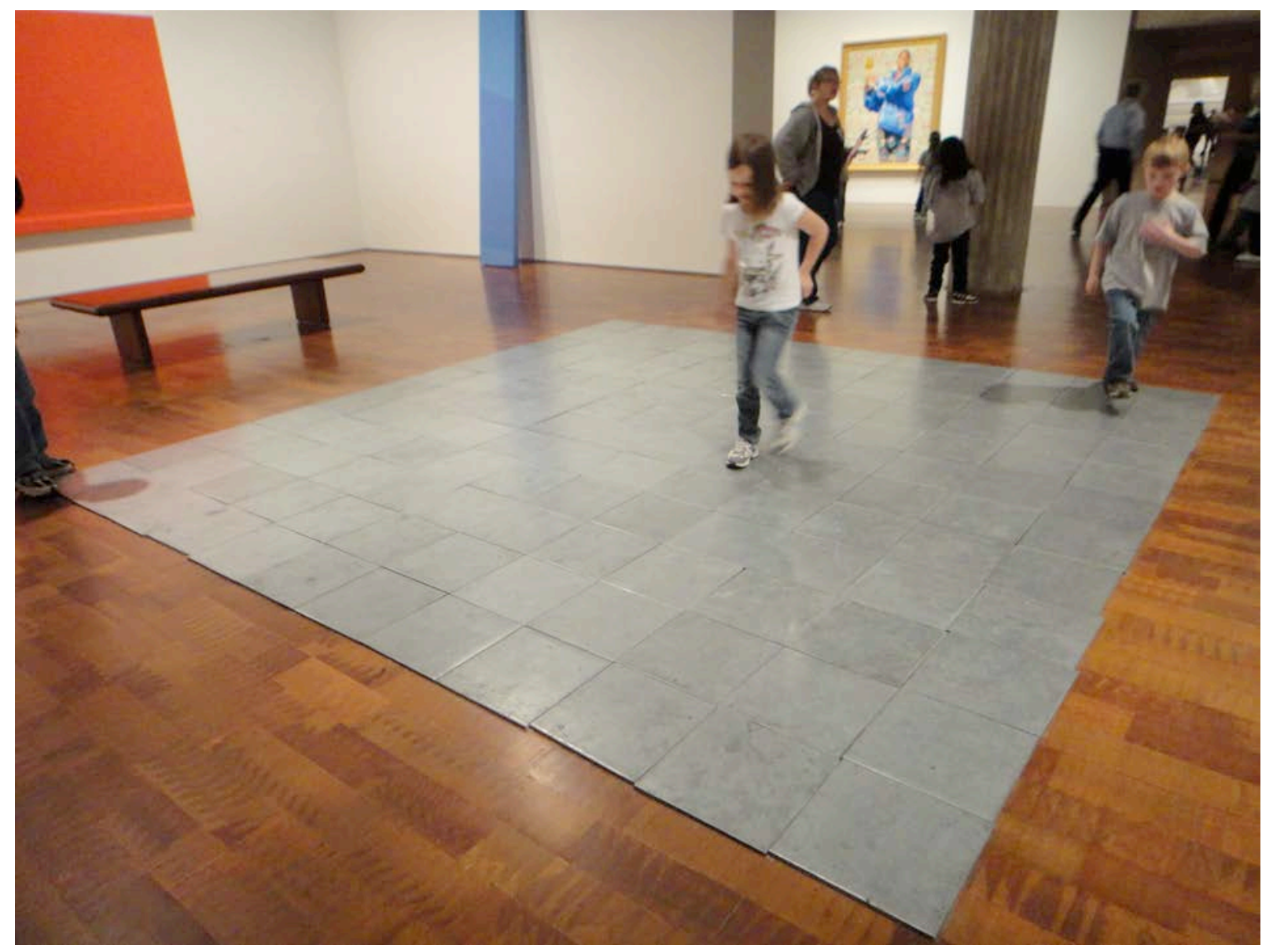

Carl Andre, 144 Lead Square (1969)

No mesmo momento, Hélio Oiticica criava Tropicália (1968) e Éden (1969), obras que igualmente engajavam o chão da galeria, mas em uma estrutura dinâmica, informal e mais complexa. Mesmo que Oiticica tenha sido outro artista que compreendeu a limitação do plano da obra e transferiu a sua prática para o espaço com os seus Relevos, Bólides, Penetráveis e Parangolés, depois do período bidimensional Oiticica nunca se deteve exclusivamente na questão da superfície, mas sim no espaço-vida. A superfície em Oiticica é explodida e considerada como um outro componente numa rede intricada de elementos relacionais, mais sugestivos do espaço da praia, com o chão da galeria coberto predominantemente de areia, um

\footnotetext{
${ }^{117}$ Neste momento o chão da galeria se torna não somente o "lugar" onde depositar a obra, mas se torna parte integral da obra e da experiência artística. Muitos outros artistas vão trabalhar com o chão da galeria e os exemplos mais significativos seriam os trabalhos em feltro de Robert Morris, os projetos de areia e pedras com espelhos de Robert Smithson, os objetos de Donald Judd, as luzes de Dan Flavin, ou os "espirros" (splashings) de chumbo de Richard Serra, etc.
} 
outro elemento desestabilizador que provoca, como em Carl Andre, o visitante a se posicionar diante da obra.

Glovetrotter (1991), de Cildo Meireles, usa uma superfície estendida como uma oferta inicial. Ao primeiro olhar nota-se mais uma paisagem do que propriamente um objeto. A iluminação dramática da sala e a sua continuidade material indefinida promove um certo desvio do corpo em relação à obra. Não se pode entrar ou andar por esta superfície, mas ela, na sua topografia sedutora, convida alguém a penetrá-la perceptivamente. Perante a esta superfície, o olho viaja e procurando um lugar (dentro) e uma posição (fora). Na abordagem do objeto, a malha homogênea em aço inoxidável, perfurada, maleável e permeável, transmite um falso preciosismo que a sua informalidade interior contradiz, pois formado por várias bolas de diferentes procedências e usos (desde uma bola de futebol, até outra de metal, de snooker, uma pérola, etc.), alude à uma diversidade inusitada. Ao penetrar a superfície, o olho paira através do seu relevo sensual.

Enquanto em Andre a identificação da superfície é imediata e conclusiva e a relação com o visitante negociada mais rapidamente, em Glovetrotter o visitante é provocado por uma variação perceptiva causada pela aparente homogeneidade estruturadora da obra (a malha), mas o grau de profundidade do interior do trabalho produz um novo tempo. Aqui, o objeto é diluído em favor da experiência. Meireles, refletindo sobre Glovetrotter:

\begin{abstract}
Comecei a pensar sobre essas esferas e imaginei algo que remete para a ideia de conquistar mundos, usando uma coleção de formas elementares e algo que, de alguma forma os contêm, e seria também uma reminiscência das grandes navegações, na idade moderna, de Portugal e Espanha e da conquista do Novo Mundo. Então eu pensei nesta malha de aço inoxidável, que tem uma incrível capacidade modular: ela possui um peso, ela retém, ela produz um campo por si só... A maioria dessas obras de grande porte... pretende ganhar alguma independência em relação ao espaço, eles buscam autonomia, criam um espaço próprio. A peça é uma experiência que existe desde a sua superfície exterior para dentro. ${ }^{118}$
\end{abstract}

Jacques Derrida, em Saufle nom, associa a natureza da superfície topológica com a própria linguagem: $\mathrm{O}$ evento continua a ser de uma só vez na e sobre a linguagem, então, no interior e na superfície (a superfície aberta, exposta, imediatamente transbordada, fora de si). O evento permanece no interior e na boca, na ponta [bout] da língua... Em Glovetrotter

\footnotetext{
${ }^{118}$ Cildo Meireles, "Glovetrotter 1991", London: The Tate Gallery, 2008-09. Disponível em: $<$ http://www.tate.org.uk/whats-on/tate-modern/exhibition/cildo-meireles>. Acesso: 13 de junho de 2010, tradução nossa.
} 
Meireles articula uma combinação entre a superfície espacial do trabalho com a linguagem (...e imaginei algo que remete para a ideia de conquistar mundos), e assim os significados e a experiência "transbordam" para além da sua materialidade, criando um novo paradigma para o objeto escultural, extrapolando os pressupostos inicialmente colocados por Carl Andre e contestados por Michael Fried. A superfície em Meireles se transforma num sistema com múltiplas entradas e relações (superfície aberta, exposta), permitindo ao observador um leque mais dilatado de re-significações, tal como acontece na linguagem e suas traduções: desde a sua superfície exterior para dentro (Meireles) > o evento permanece no interior e na boca, na ponta da língua (Derrida).

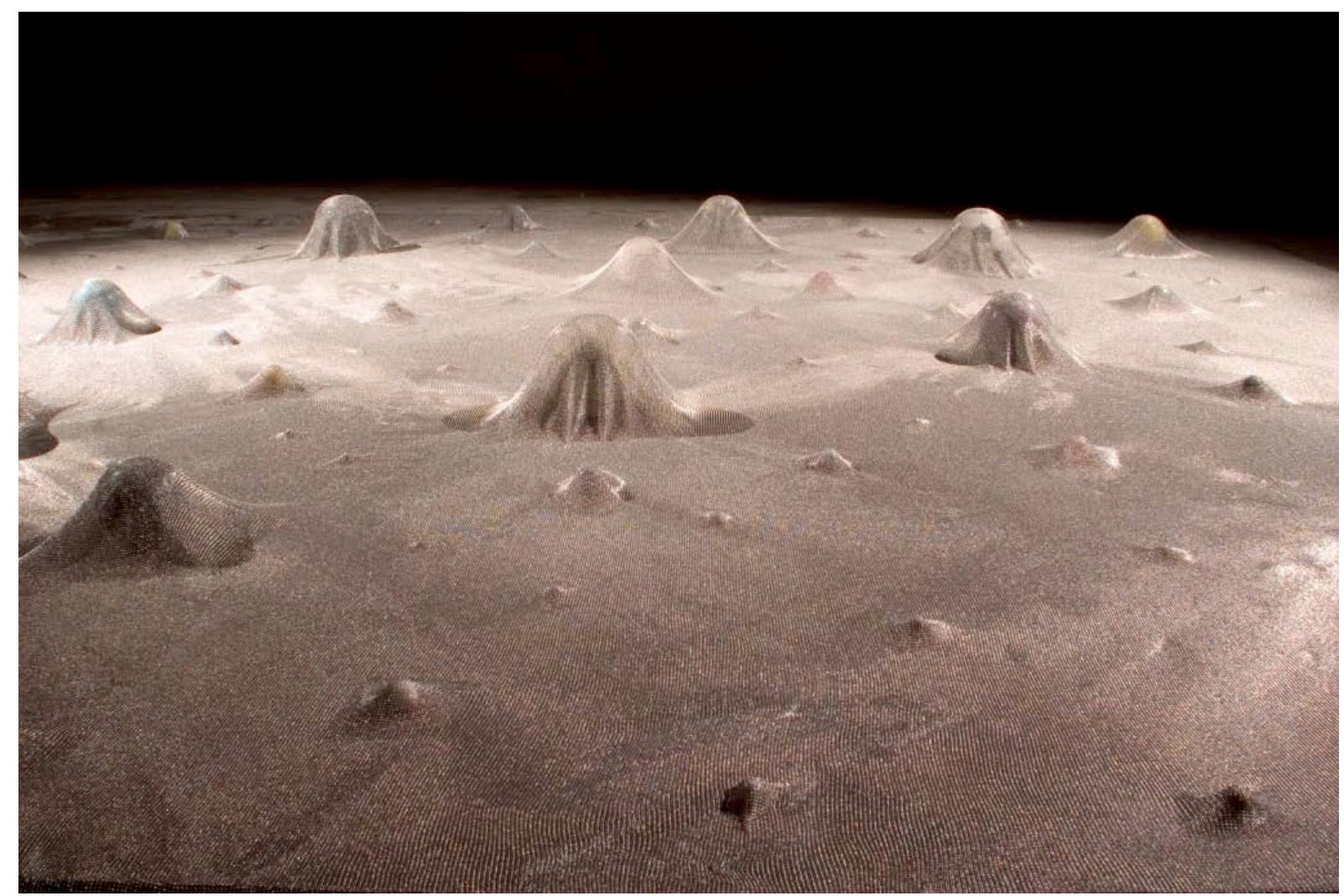

Cildo Meireles, Glovetrotter (1991)

O ajuntamento "desde a sua superfície exterior para dentro o evento permanece no interior e na boca, na ponta da língua" conduz a uma imagem exata de Untitled (Portrait of Ross in L.A.), de 1991. González-Torres elaborou Untitled como uma metáfora do corpo de Ross, afligido pela Aids, que gradualmente perde peso. Untitled funciona ao mesmo tempo 
como autorretrato ${ }^{119}$, instalação e escultura, um memorial, uma conversa, um presente, mas acima de tudo coloca em questão a relação do visitante com o trabalho, coloca em questão a relação da instituição com o trabalho a partir da superfície estendida, constantemente transformada e reconstruída, onde cada fragmento se espalha a partir da escultura para o corpo daqueles que com ela interagem. Aqui a superfície é finalmente subvertida produzindo uma abertura total do trabalho.

Em Untitled (Placebo - Landscape - for Roni) (1993), González-Torres cria outra superfície feita com balas embrulhadas com papel dourado brilhante. Aqui também o "tapete de balas" é apresentado como um objeto a ser transformado pela ação dos visitantes na medida que qualquer um pode levar uma ou várias balas como um presente. A natureza do objeto é então questionada simultaneamente no ato da experiência artística. Levo ou não levo? Se levo, chupo a bala ou guardo? É arte ou não é arte? Nancy Spector delineia por ocasião da exposição Paired, Gold: Felix Gonzalez-Torres and Roni Horn, no Museum Guggenheim de New York (2010), que o diálogo estético entre Félix González-Torres e Roni Horn está baseado em uma troca de ouro, um presente recíproco entre dois artistas que ressoa com a poesia de seus respectivos projetos. Em 1990, durante uma exposição individual de Horn, no Museu de Arte Contemporânea de Los Angeles, González-Torres encontrou Forms from the Gold Field (1980-82), constituída de dois quilos de ouro puro comprimido em um tapete retangular luminoso. Horn situou o trabalho diretamente no chão de uma galeria vazia, com o trabalho "correndo o risco de dissolver-se em uma imaterialidade deslumbrante, a sensação de pura superfície que sua delicadeza invoca." ${ }^{20}$ Impressionado com a sua simplicidade radical e suas capacidades emotivas, Gonzalez-Torres compartilhou sua memória de trabalho com Horn quando eles se conheceram em 1993. Poucos dias depois, ela enviou-lhe um quadrado de folha de ouro como um símbolo de sua amizade recém-descoberta e sensibilidades compartilhadas. Em 1993 ele ficou tão inspirado pelo seu gesto e pela consciência sutil da sua obra que ele fez o seu próprio "campo de ouro" em sua homenagem: Untitled (PlaceboPaisagem-para Roni ), um transbordamento de balas infinitamente substituível embrulhado em celofane de ouro. Gonzáles-Torres descreveu o Gold Field de Horn como uma nova

\footnotetext{
${ }^{119}$ Tanto González-Torres como também seu namorado Ross Laycock contraíram Aids. Os trabalhos com balas, empilhadas ou em superfície eram frequentes memoriais a Ross, que o considerava "o seu único público", mas por conseguinte eram também autorretratos do artista.

${ }^{120}$ Nancy Spector, "Paired, Gold: Felix Gonzalez-Torres and Roni Horn”, New York: Guggenheim Museum, 2010. Disponível em: <http://www.guggenheim.org/new-york/exhibitions/past/exhibit/3155>. Acesso: 03 de outubro de 2013, tradução nossa.
} 
paisagem, um horizonte possível, um lugar de descanso e beleza absoluta.

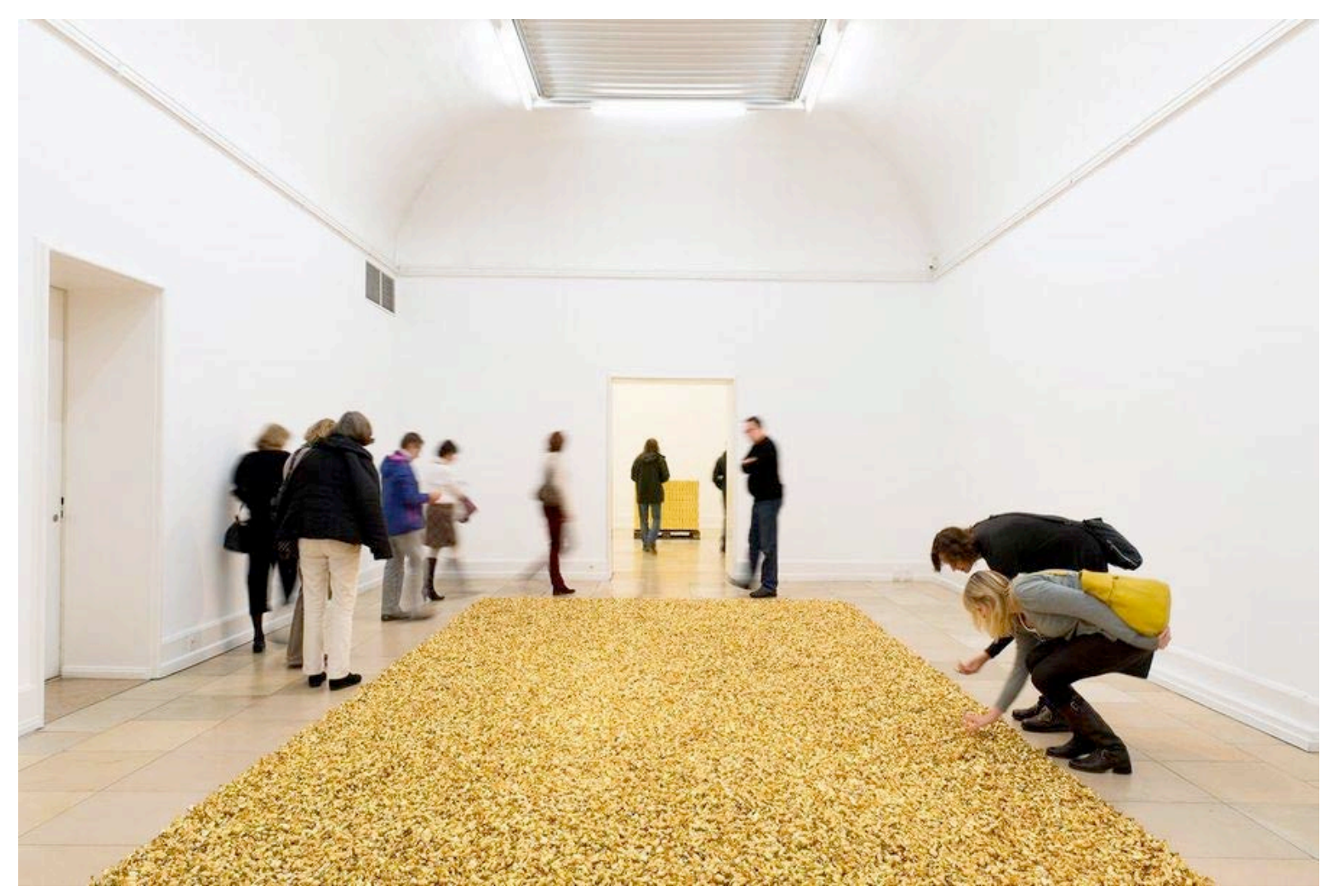

Félix González-Torres, Untitled (Placebo-Landscape-for Roni) (1993)

A partir do trabalho de González-Torres, a superfície explode para além do objeto e cria relações em suspensão e rupturas/aberturas fundamentais no corpo e no espaço para além do espaço institucional. A objetidade a qual Fried se referia quanto à escultura minimalista é alterada para um campo aberto, mesmo que ambos trabalhos Untitled (Placebo-Landscape-for Roni), de González-Torres e Glovetrotter, de Meireles se utilizam de elementos formais paralelos à sensibilidade minimalista, a proposta é um novo paradigma para o objeto escultural na sua maneira de utilizar e trabalhar os materiais e a sua superfície. A caracterização deste novo momento pode ser resumida à “interioridade” impregnada no trabalho. Esta qualidade "interior" se desdobra do aspecto formal pelas balas "embrulhadas" (González-Torres) ou pelas bolas “cobertas” (Meireles), revelando o trabalho não de imediato, na sua aparência imediata, mas convidando o visitante a gradualmente penetrar na sua própria interioridade em relação à interioridade da obra. Como Richard Serra diria, a beleza não é uma qualidade do objeto, mas habita em todos aqueles que se relacionam com o objeto. Nesse sentido, podemos dizer que a experiência continua no interior de cada indivíduo e da 
sua linguagem pessoal.

A superfície-mundo assume a sua totalidade quando não se limita aos elementos formais da obra e encontra outras dimensões de significações a partir da nova interatividade, pronunciada para além da manifestação física, visual do objeto. Esta é talvez a principal contribuição da arte pós-minimalista para a formação de uma epistemologia da superfície nas práticas artísticas. Enquanto o pós-minimalismo foi fundamental na articulação dos procedimentos transformadores do objeto ao convidar o visitante a participar da obra de maneiras mais envolventes, no Brasil a contribuição de Lygia Clark para o entendimento da transformação da superfície da obra de arte foi vital. A transição da bidimensionalidade da tela para o espaço foram um dos procedimentos mais comumente partilhados entre artistas da segunda metade do século 20. Talvez o processo mais lúcido e rigorosamente documentado foi exatamente a experiência de Clark, que Ferreira Gullar assim sintetiza:

\footnotetext{
[No trabalho de Lygia Clark] o espaço pictórico se evapora, a superfície do que era 'quadro' cai ao nível das coisas comuns e tanto faz agora esta superfície como a daquela porta ou daquela parede. Na verdade, liberto o espaço preso no quadro, liberto minha visão e, como se abrisse a garrafa que continha o Gênio da fábula, vejoo encher o quarto, deslizar pelas superfícies mais contraditórias, fugir pela janela para além dos edifícios e das montanhas e ocupar o mundo. É a redescoberta do espaço. ${ }^{121}$
}

Para Gullar, a ocupação do mundo não se dá a partir do objeto em si, mas a partir daquilo que o objeto provoca no artista e naquele que experimenta a obra, amalgamando a experiência artística com o mundo em torno, formando uma concepção de espaço para além da bidimensionalidade do quadro: Espaço é exatamente esta contiguidade, esta continuidade entre o ser e o lugar, formando assim uma coerência inexorável entre o corpo e a realidade em volta, entre representação e experiência - um espaço-vida.

A simultaneidade entre sujeito, tempo, espaço e matéria fica em evidência em Caminhando. A partir de uma tira de papel, vira-se uma de suas extremidades que é então fixada na outra extremidade da tira, construindo-se assim uma fita de Moebius. Então cria-se uma incisão com uma tesoura no sentido longitudinal da tira, e corta-se em linha, um corte paralelo ao seu comprimento, em um percurso que, devido à geometria da fita terminaria no seu começo. Neste exato momento, quando o corte encontra o seu começo, desvia-se com a tesoura para a direita ou para esquerda para continuar o processo, e assim persiste-se neste

${ }^{121}$ Cf. Ferreira Gullar, Experiência neoconcreta. São Paulo: Cosac Naify, 2007, p. 87. 
movimento e, quando chegar no seu final, desvia-se e continua cortando, e assim por diante.

Em Caminhando, não existe separação entre aquele que executa a obra e aquele que experimenta a obra, e tudo ocorre num mesmo espaço-tempo. De repente, a trinca única homem-obra-espaço, todos são apenas um. Dentro da delicada intensidade de Caminhando, o plano da folha de papel vai gradualmente se transformando em espaço, numa complexidade crescente só definida quando aquele que a corta decide parar. A tridimensionalidade gerada se multiplica em infindas relações espaciais pois, muito além da lógica da fita de Moebius, que tem uma única superfície contínua, Caminhando cria um espaço novo, com sequentes planos entrelaçados, sem chegar a uma coerência precisa, mas que, na sua geometria gradualmente mais complexa, determinado tanto pela resposta do material quanto pela ação transforma o trabalho em um novo modelo de pensar-viver. O local da obra é o próprio corpo do criadorobservador, e o tempo da obra é o momento simultâneo onde a obra ocorre, quando ela é criada.

Nunca "vi" Caminhando, numa galeria de arte ou museu, sendo apresentado como objeto. Em 1988, realizei o Caminhando de Clark em casa, no meu apartamento da Rua Waverly, em Montreal. Mas era um Caminhando diferente. Levei-o para o extremo. Uma fita de papel muito mais larga e muito mais comprida que o convencional, como visto em imagens anteriores do trabalho. A dimensão exagerada permitia um Caminhando mais longo, sugerindo um percurso tanto em termos de tempo e espaço mais duradouro e complexo. $\mathrm{O}$ resultado é mais do que um objeto semelhante ao Caminhando de Clark se assemelhando mais a um emaranhado, um labirinto impossível de se escapar. A superfície foi então estendida para além da lógica (a fita Moebius) e exagerada na sua ação (cortes múltiplos contínuos), e na sua complexidade geométrica uma aproximação com a condição-praia.

Mas tem também os Bichos de Clark. Esses sim, as únicas vezes que tive a oportunidade de presenciá-los foi na sua apresentação em espaços institucionais. Aqui a instituição sempre se impôs acima do objeto, este, que na sua essência foi criado para ser manipulado, experimentado, transgredido. Manipulação esta impossível, pois na ambição de construir a aura sobre o objeto todas as instituições que administraram os Bichos os dispôs sob caixas de vidro ou os colocou supervisionados sob a tutela cerrada de guardas de museu. Como então uma instituição que aparentemente reconhece o conceito de um objeto de arte e então o apresenta, não compreende o seu sentido na sua forma mais elementar? Como instituições podem ser tão despreparadas para exibi-los, dissociando-se totalmente da 
intenção original do artista?

Não só a ironia da aura da obra de arte sempre rondou os Bichos, mas acima de tudo a incompreensão de que o alumínio não é um material precioso, mas leve, de grande resistência e indutivo à manipulação. Barato e industrial, a chapa de alumínio permite a reprodução industrial em série. É sabido que Clark considerou a fabricação em série dos Bichos, mas algum empecilho impediu a sua realização. Tanto Caminhando quanto Bichos promoveram a passagem do plano bidimensional para o espaço através de uma superfície transformada pela experiência fenomenológica, reconhecendo a simultaneidade criador-observador em íntegra coexistência com o corpo, o tempo e o espaço da obra (arquitetura-corpo), transformando a sua geometria para além das suas atribuições objetivas de superfície. Tanto Bichos quanto Caminhando, em suas transposições do espaço individualizado da experiência para o espaço público da instituição, sugerem no curto-circuito que criam entre obra de arte e museu/galeria uma nova tipologia: além de superfície sensorial, torna-se também superfície política, então uma superfície ativada pela experiência individual de cada um, pela vida em si. Através da transgressão do objeto, da reinvenção da sua superfície, alterada agora pela ação direta do participante, Lygia propõe a inclusão integral do participante na obra. Este envolvimento totalizante com a experiência é o que abre as infinitas possibilidades de uma simples superfície, agora transformada para o mundo: uma superfície-mundo. 


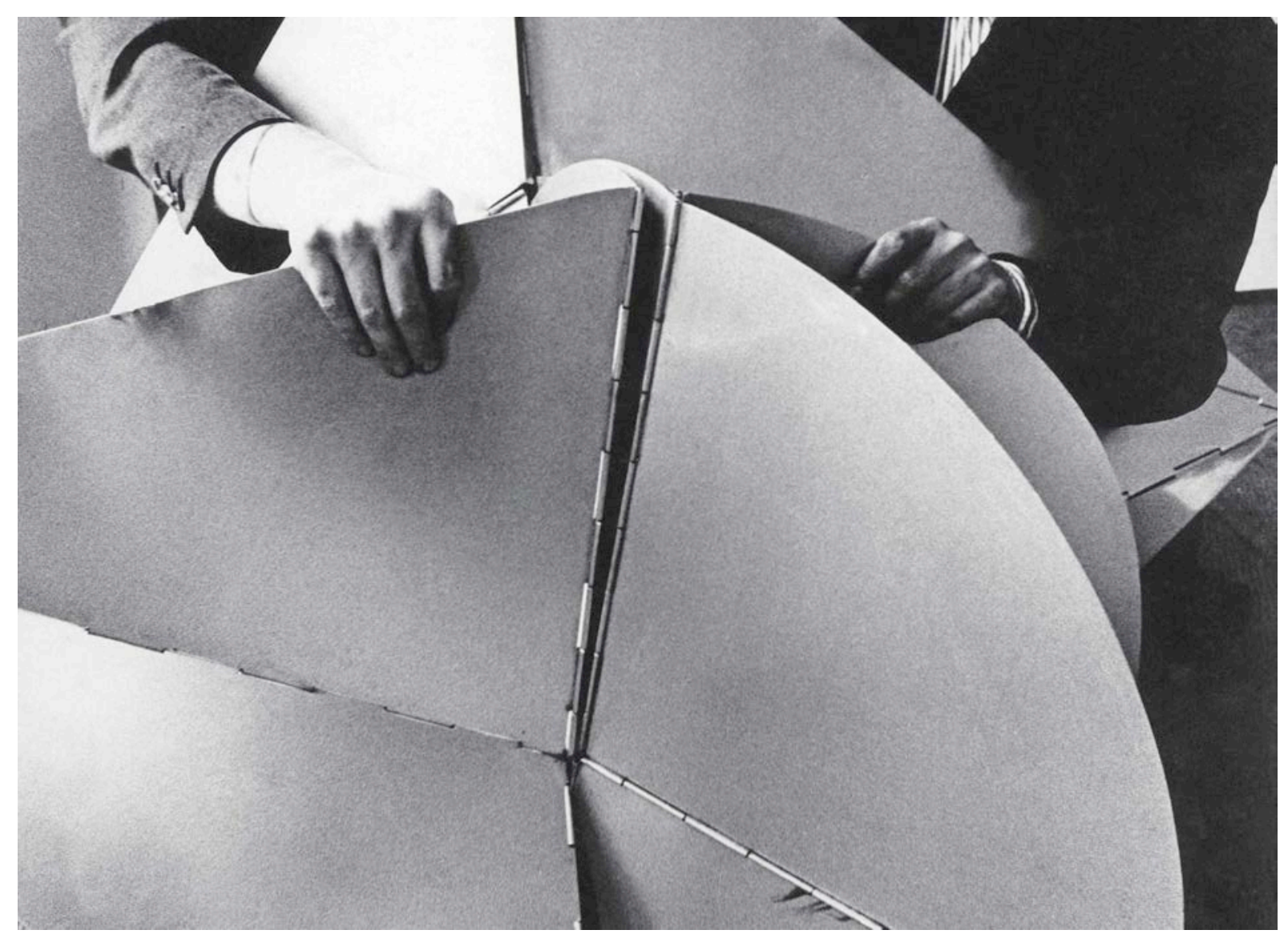

Lygia Clark, Bichos (1960-64) 


\title{
7_ COPACABANA COMO MODELO URBANO
}

\begin{abstract}
Copacabana é mais que um bairro. Ela é um limite entre a cidade e o reduto. Copacabana trafega entre o sensível, visível externamente e oferecido por formas, cores, arquitetura, tráfego, e gente, e, por outro lado, espaços reduzidos à invisibilidade da vida cotidiana em que se submergem milhares de pessoas, rostos anônimos carimbados por uma vida desconhecida. Wilson Coutinho, Copacabana, cidade eterna ${ }^{122}$
\end{abstract}

\section{I_Copacabana: a praia e o mito}

A praia enquanto fenômeno só começou a fazer parte do meu processo formativo a partir das observações feitas durante a realização do Projeto Camelô, no Museu de Arte Moderna do Rio de Janeiro em 2001, em colaboração com Karen Shanski. Na ocasião, essa construção crítica do espaço da praia estabeleceu-se como elemento formador de uma outra consciência.

Shanski, vinda das pradarias canadenses, uma paisagem interior desolada, despida de costas, densidades, topografias e fronteiras físicas, desenvolveu uma percepção precisa para os mais diversos aspectos e dinâmicas do espaço da praia de Copacabana, um espaço diametralmente oposto ao das pradarias. ${ }^{123}$ A praia, desde então, fazia parte somente do meu inconsciente imaginado. Mas então, filtrado pela experiência da distância e engajado por um novo olhar, muitos aspectos desta experiência do lugar floresceram para informar a prática do desenho; isto é, Copacabana tornou-se uma referência direta para a nossa própria prática do desenho.

Este distanciamento aguça as percepções sobre o "outro", como podemos notar em uma das abordagens sociológicas mais contundentes sobre as praias da zona sul carioca, do acadêmico e geógrafo americano James Freeman. Freeman afirma que as grandes cidades latino-americanas estão cada vez mais polarizando o espaço público no esforço de superar a violência. Mas mesmo que a tendência é de transformar estes espaços em espaços públicos mortos, um domínio público excepcionalmente vibrante sobrevive no Rio de Janeiro. Nos bairros da zona sul os moradores passam grande parte de seu tempo livre em público: nas esquinas, nos bares, e na praia. Vizinhos, amigos e colegas de trabalho vão de dentro para fora em uma vida social pública intensa. Para Freeman abaixo desta superfície idílica alimentada pela praia encontra-se um espaço social conflituoso pelas divisões raciais e de classe. Mesmo

\footnotetext{
122 Wilson Coutinho. Copacabana, cidade eterna: 100 anos de um mito. Rio de Janeiro: Relume Dumará, 2001, p. 9.

${ }^{123}$ Por contradição, as pradarias se localizam num fundo de um antigo mar, o glacial Lago Agassiz.
} 
assim esta sociedade "lubrifica" as zonas comerciais, promove a democracia e resolve seus próprios problemas de interesse comum. Este processo ainda permite a participação de todos em uma verdadeira possibilidade política. ${ }^{124}$ As observações de Freeman confirmam aqui a posição de Fredric Jameson, que considerou 'critical distance' como sendo um hábito típico do pensamento moderno, agora abolido no novo espaço pós-moderno. Para Jameson, estamos submersos até o ponto onde nossos corpos são agora despojados de coordenadas espaciais e praticamente (para não falar teoricamente) incapazes de distanciamento. ${ }^{125} \mathrm{Um}$ distanciamento é necessário quanto da abordagem do objeto e tanto Shanski nas suas observações intuitivas, quanto Freeman na sua crítica social ratificam a acepção de Jameson ao trazer o seu olhar estrangeiro à praia brasileira.

Através de um estudo etnográfico de um trecho da praia de Copacabana e Ipanema, James Freeman argumenta que o espaço público da cidade pode atuar como uma espécie de esfera pública, onde a política de classe cotidiana e a interação racial podem ser representativas da escala política maior, mesmo em uma cidade muito dividida como o Rio de Janeiro. Mas nas praias do Rio de Janeiro podem conferir uma espécie de cidadania marginal a seus usuários. Eles não formam necessariamente a democracia discursiva idealizada por parte da teoria social, nem são os espaços sem classes, altamente miscigenados que a elite brasileira adora mitificar, mas sim articulam territórios de profundos conflitos, onde os arrastões, por exemplo, surgem como um clímax tenso da realidade social urbana. Em um primeiro momento, se o espaço pessoal (das elites) é respeitado e seguro, a impressão de "democracia" parece se evidenciar, mas na mínima ruptura deste espaço personalizado, a questão do conflito revela-se publicamente, mesmo através de eventos inofensivos, como o oferecer de uma bebida por um vendedor ambulante, ou uma bolada acidental no ombro. Pelo contrário, estes eventos demonstram a desigualdade política, o confronto de classes em que a legitimidade da ordem social é desafiada e renegociada continuamente, mesmo através de um simples olhar ou pela ação da polícia, desafiando o mito da democracia no contexto urbano.

\footnotetext{
124 James Freeman. Great, good, and divided: the politics of public space in Rio de Janeiro. Journal of Urban Affairs, v. 30, n. 5, p. 529-556. Hoboken, NJ: Wiley, 2008.

${ }^{125}$ Fredric Jameson. Postmodernism, or, The Cultural Logic of Late Capitalism, London: Verso, 1991.
} 


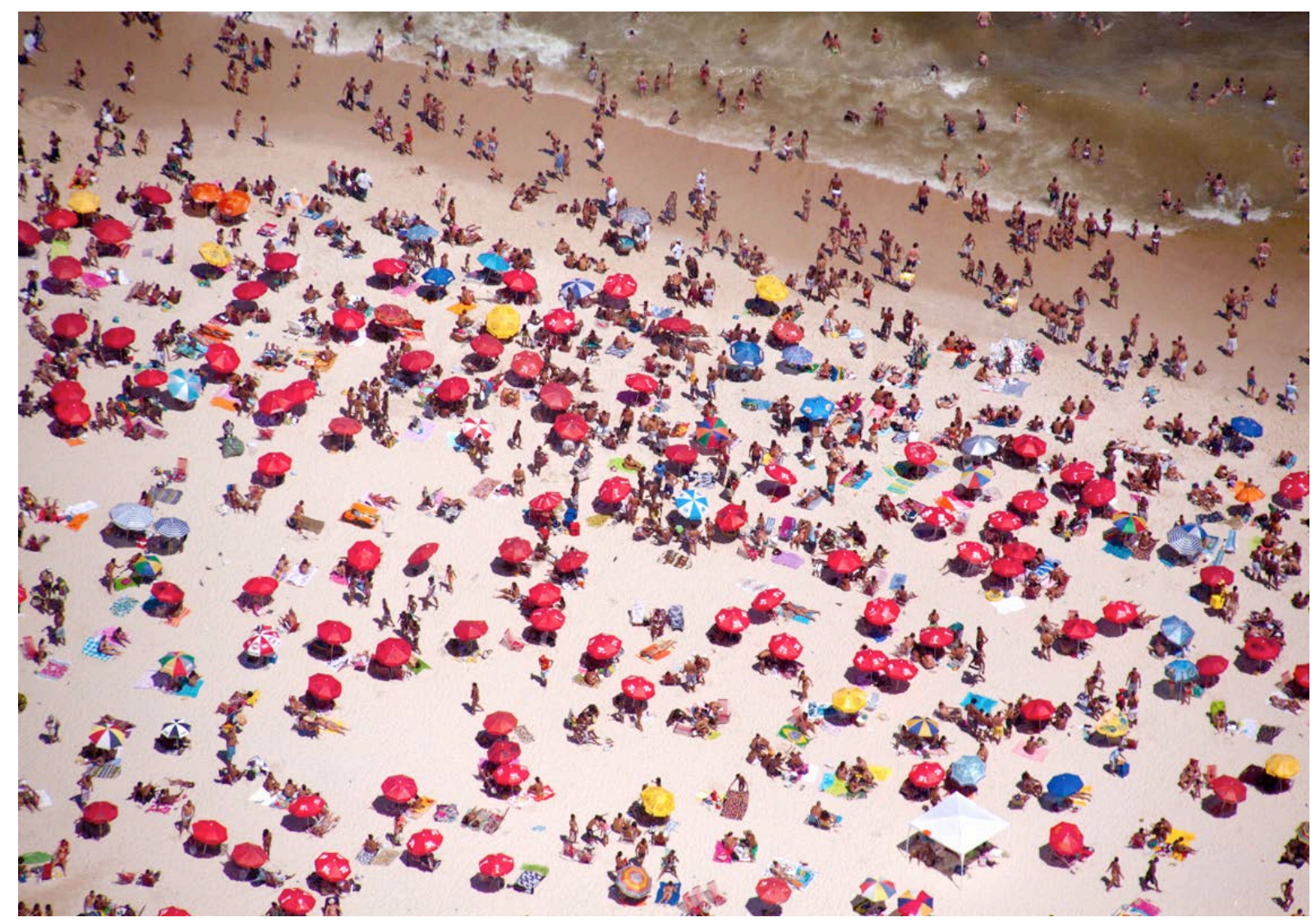

Copacabana é mais que um bairro. Ela é um limite entre a cidade e o reduto.

O espaço público de Copacabana é essencialmente controlado pela classe média predominante do bairro e de bairros afins. Os extremos sociais - tantos os ricos como os pobres - têm uma necessidade maior de negociar os seus direitos a esses espaços: Os ricos na sua tentativa de "higienização da praia" e os pobres pelas suas lutas em relação ao acesso e à própria habitação e usufruto do espaço. Todas as camadas de negociação, tanto das conversas informais até às instalações de quiosques, revelam as complexas camadas das condições encontradas na praia. Tal complexidade, para Freeman, expõe a realidade política maior do país no microcosmo de Copacabana. Aqui observamos que Freeman se utiliza do modelo de Copacabana para entender a esfera pública maior da cidade do Rio de Janeiro ou até do Brasil. Em contrapartida, uma epistemologia da praia de Copacabana detecta dispositivos de desenho que promovem esta complexidade totalizante e sintetizante da sociedade brasileira no que diz respeito a espaços públicos urbanos. De uma certa forma, Casa Grande e Senzala, de Gilberto Freire, articulou semelhantes dinâmicas sociais em relação à arquitetura brasileira colonialista. Não seria o caso então de considerarmos uma leitura do espaço público da praia de 
Copacabana, e da compreensão das suas dinâmicas, para assim ampliar as possibilidades estratégicas de criação, influenciando as políticas determinantes do espaço urbano?

Mesmo de maneira desigual, podemos concordar que todos aqueles que ativam este território encontram as suas próprias representações e, engajando com o lugar e com todos os seus atores, trazem uma vida intensa ao espaço. Esta intensidade de vida, representada por todas as atividades possíveis que se dão na praia, formam o equivalente a um programa inverso. Tradicionalmente o arquiteto junto com o cliente determinam o destino de cada espaço através do programa do edifício. Por outro lado a indeterminação do espaço da praia cria uma potencialidade muito maior onde tanto a ocupação como a habitação de cada metro quadrado é deixado em aberto, suspenso, a ser negociado cotidianamente no imprevisível.

Como nas relações sexuais, é esta tensão política e social de Copacabana e das praias da zona sul carioca que exacerba o erotismo das relações entre as pessoas e entre elas e o território, exatamente o que gera uma vida excepcionalmente vibrante neste espaço público. De maneira inversa é a própria tensão que gera um processo de conscientização entre as pessoas - não se pode mais ignorar estes pequenos detalhes relacionais (o vendedor ambulante, a bola de futebol, um onda mais forte) nem tão pouco os grandes (o concerto, a partida de futevôlei, o réveillon ou mesmo um arrastão) - pois agora estamos completamente vivos e engajados no espaço. Este engajamento necessário é o que eleva, contraditoriamente, o atributo "público" da praia. O acordo entre a consciência social pública elevada com as características infraestruturais e ambientais de Copacabana resultam em um espaço público altamente bem-sucedido. Mais do que um destino de lazer, Copacabana gera um sentido forte de estarmos vivos, de estarmos participando ativamente na construção social de uma comunidade. Aquele que habita Copacabana nunca o faz de maneira passiva, mas sim engajado, consciente ou inconscientemente, mas engajado com a esfera maior da vida pública política do país. Não podemos separar a vida do bairro da vida da praia, pois é neste sincretismo de vidas que uma alimenta a outra, o que Caymmi deixou evidente em Sábado em Copacabana:

Depois de trabalhar toda a semana

Meu sábado não vou desperdiçar

Já fiz o meu programa pra esta noite

E sei por onde começar

Um bom lugar para encontrar: Copacabana

Prá passear à beira-mar: Copacabana 


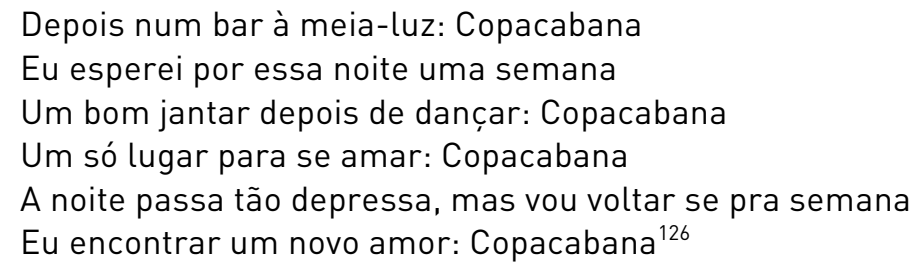

Então, se compararmos esta qualidade humana-espacial encontrada em Copacabana - e celebrada por Caymmi - com a maioria dos espaços públicos encontrados nas grandes metrópoles, concluímos que de fato temos algo que aprender e apreender, haja vista as grandes dificuldades da arquitetura e do urbanismo em gerar espaços com as qualidades, intensidades e engajamentos semelhantes aos encontrados aqui. A tendência é que os espaços considerados "públicos” das metrópoles passem pelo crivo gradual da globalização dominante, promovendo cada vez mais a sua privatização e, como consequência, criando cada vez mais fortalezas para o usufruto das classes dominantes. Mesmo bombardeada pelo processo globalizante, Copacabana resiste ao processo de privatização, dada a sua profunda vocação histórica e cívica de um espaço público acessível. Esta resistência ao tempo, às forças das dinâmicas globais que tendem a dissipar o que o local resguarda de melhor é o que Caymmi revela em Sábado em Copacabana, demonstrando uma qualidade urbana que ainda perdura no bairro (Um bom lugar para encontrar / Prá passear à beira-mar / Depois num bar à meia-luz), fazendo crer que é na dialética praia-cidade onde temos a maior perspectiva para a cidade humanística: o encontro entre a beira-mar e um bar à meia-luz.

Em uma fotografia aérea de Copacabana dos anos 1970, Walter Firmo revela através de uma única imagem a complexidade espacial da praia pelas múltiplas relações que podemos extrair. A imagem cobre uma área de cerca de $1.500 \mathrm{~m}^{2}$. O que permite um exame mais específico é a ausência significativa dos guarda-sóis naquela época, ainda não invadida com barraquinhas de aluguel como vemos hoje, o que permite um panorama mais claro das atividades presentes. Esta imagem serve como uma síntese, como uma acumulação de condições para compreendermos melhor as dinâmicas do espaço. Existem várias situaçõescorpo que revelam a natureza das relações humanas. Amigos que se encontram numa rodinha, casais que se deitam ao sol, crianças brincando na companhia dos pais, solitários que se espreguiçam na areia, transeuntes, leitores, namorados, ambulantes, famílias, toalhas vazias que sugerem um mergulho no mar, amigas conversando, etc. Cada uma dessas relações

126 Dorival Caymmi e Carlos Guinle, Sábado em Copacabana. Disponível em: <http://www.letras.com.br/\#!dorival-caymmi/sabado-em-copacabana>. Acesso: 21 de junho de 2012. 
humanas estabelecem a presença de uma tribo específica, bem diferenciada uma da outra, mas que ocupam juntas um mesmo pedaço de areia.

Em relação ao ambiente físico, a imagem revela a continuidade de uma superfície mole, que é a areia fofa de Copacabana. Nem todas as praias apresentam este mesmo tipo de areia, mas a areia branca e fofa seja talvez o material mais ideal para cobrir um espaço público, oferecendo ao andar, o ficar de pé, o sentar-se e deitar-se a possibilidade confortável da adaptação do corpo sem necessariamente o uso de mobiliário ou outro tipo de superfície para tal. A presença do sol no Rio de Janeiro também favorece uma permanência mais longa na praia, haja vista a sua presença em média de 300 dias por ano, com temperatura média de $24^{\circ} \mathrm{C} .{ }^{127}$ Contrapondo a intensidade do sol, temos um mar agitado, com ondas espumantes, com a água numa temperatura agradável, o que permite um engajamento com a água de maneira facilitada. Em relação à presença racial vemos brancos, mulatos, cafuzos, pretos, cores que alcançam uma ampla gama de variedades de pele. Distinguimos também a presença cultural da moda, com seus trajes de banho e seus guarda-sóis coloridos.

Outros aspectos fundamentais representados na imagem mas menos evidenciados na sua iconografia são exatamente os aspectos sociais, econômicos e políticos. A praia subsiste com uma economia própria, economia aqui vista não somente como disciplina técnica mas como fenômeno. É claro que se observamos um ambulante sabemos que existe uma troca comercial, uma venda, uma transação. Tal transação é também um indicativo das diferenças sociais encontradas em Copacabana, pois se existe aquele que vende, existe quem compra. Se olharmos a economia como fenômeno podemos ampliar o seu sentido para outras formas de troca, vistas nas dinâmicas entre as diferentes tribos, por exemplo. Uma conversa é uma troca, uma troca de olhares significa uma outra forma de transação. Através de diferentes formas de comunicação encontramos diferentes formas de trocas, que estabelecem assim outras relações, outras economias. Embutidos nas dinâmicas de troca observamos também condições políticas de ocupar o território. Por exemplo, na imagem de Firmo vemos que as distâncias entre os diferentes grupos e tribos são aparentemente iguais, o que significa uma decisão inconsciente e natural. Imaginamos assim que quanto mais cheia a praia se encontra estas distâncias diminuem, intensificando a economia de trocas.

\footnotetext{
${ }^{127}$ Fonte: Tabela climática da cidade do Rio de Janeiro, World Meteorological Organization (4 de janeiro de 2012).
} 


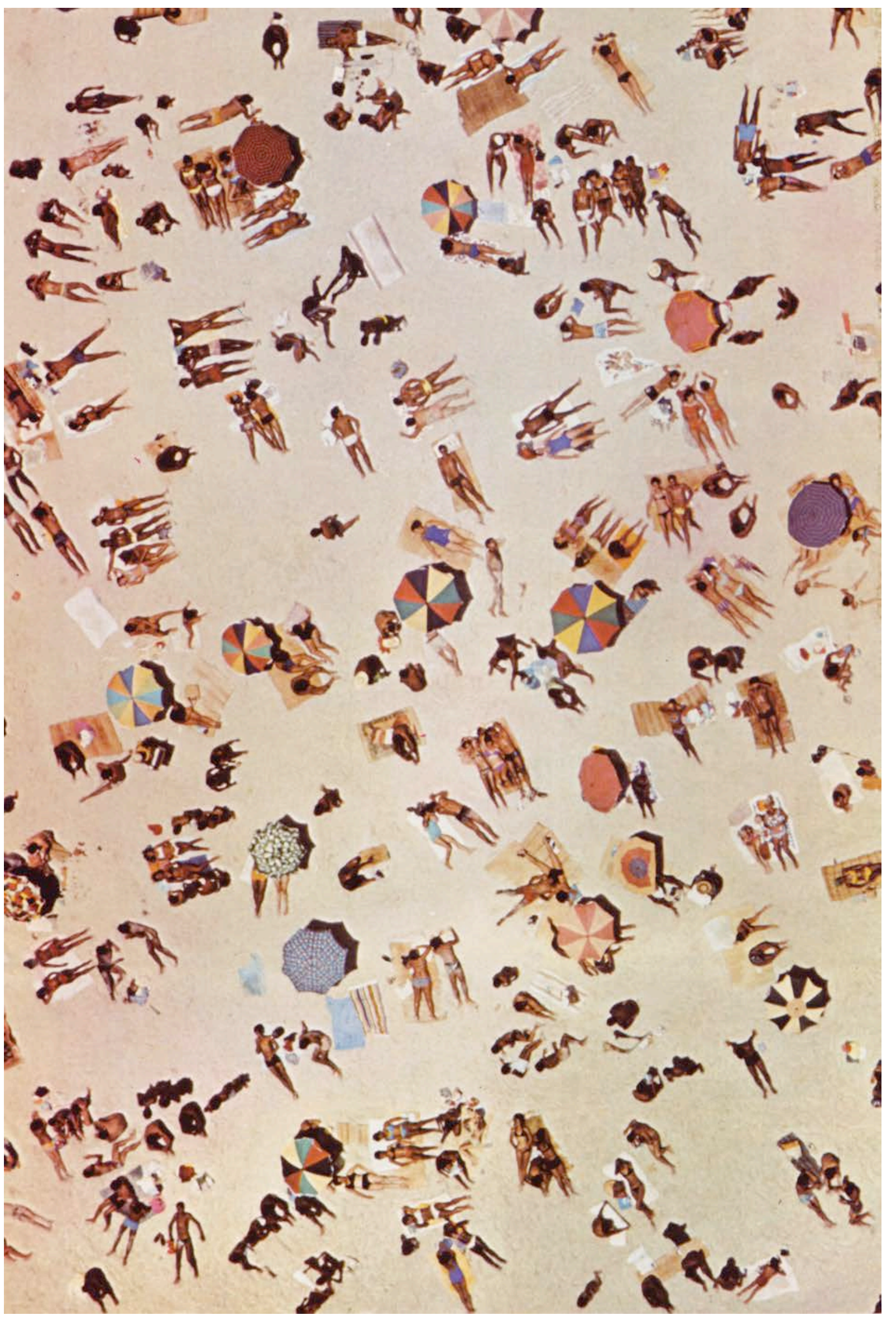

Walter Firmo, Copacabana (1970) 
Portanto, tanto nos aspectos ambientais, como nos aspectos ergonômicos, culturais, econômicos e políticos, cada condição encontrada revela um caráter equivalente à ideia de programa, pois cada atividade diferente está diretamente relacionada a uma condição de lugar ideal, permitindo assim que ela se suceda. Podemos aqui revelar uma variedade infinita de condições, atividades e situações, mas o que fica evidente é a flexibilidade da superfície da praia em receber uma grande escala de possibilidades. No caso de Copacabana, essas condições são exacerbadas exatamente pela combinação dos elementos paisagísticos com os elementos de uma rica cultura urbana, ampliando assim a complexidade das camadas existentes neste espaço público. A infinidade de possibilidades de ocupação é aumentada pelo fato de que cada ocupação diferente se dá de maneira diferente a cada dia, sem que os aspectos físico-ambientais deste espaço mude radicalmente. Podemos então aqui inverter tais condições para identificar as situações espaciais que permitem tal riqueza e flexibilidade. Então, se considerarmos tais condições flexíveis porque então outros espaços públicos e arquiteturas não podem assumir características semelhantes, aprendidas na condição-praia ou praiapaisagem?

Copacabana, vista pela ótica da cultura popular, assume a dimensão maior do erotismo urbano. A articulação criada entre a faixa de areia, esplendorosa, olhando para o horizonte, ladeada pela sensualidade de uma pedra como o Pão de Açúcar e pela frigidez massiva do Forte de Copacabana, ou da frontalidade dos edifícios da Avenida Atlântica, cria uma tensão urbana difícil de experimentar em qualquer outro conjunto. O bairro em si, um dos mais densos do Brasil, carrega o misticismo maior do imaginário brasileiro, com suas diversidades e contradições, acumulando os mais radicais dramas da vida urbana. A compressão entre a evidente paisagem de prazer da praia, da sensual topografia carioca, com o dinamismo exagerado da metrópole do século 21 por entre seus prédios e ruas, forma um laboratório primoroso onde podemos observar as condições que direcionam às possibilidades de uma vida urbana intensa dentro das possibilidades de um desenho estruturador e maleável. Como Copacabana pode sugerir um outro desenho? Talvez pautado pela imprevisibilidade, pela organização peculiar dos seus agentes, podemos conferir um caráter indeterminado, definido pelos complexos cruzamentos entre o físico e o social.

Imaginamos esta estrutura a começar pelo grande adensamento. O grande número de habitantes força uma organização urbana que luta pela própria eficiência. O estreitamento da superfície urbana, dada pela proximidade dos morros e a compressão natural contra o mar 
não só obriga uma fluidez constante de corpos e carros como mantém uma percepção plena de um sentido de lugar, um sentido de estar: Sempre sabemos onde estamos em Copacabana devido à presença constante de referências claras, como as artérias maiores das Avenidas Atlântica, Nossa Senhora de Copacabana ou Barata Ribeiro, ou das vistas entrecortadas dos morros e até pelo momento quando atravessamos um de seus túneis. Mas o que mas intensifica este sentido de lugar é exatamente a faixa de areia, que funciona como válvula de escape às tensões encontradas nas zonas de produtividade do bairro, concentradas tanto nas vias comerciais tanto nas residenciais. A faixa de areia funciona como um pulmão, como uma abertura visual e espacial em contraste às muralhas de edifícios contínuas presentes do início ao fim do seu tecido urbano.

Esta intensidade erótica do bairro, gerada pelas múltiplas tensões entre os seus atores, produz um deslumbre que permeia a vida cotidiana de Copacabana. As referências não mais estáveis revelam-se pela flutuação constante de corpos, carros, edifícios e natureza, a ponto da impossibilidade de agarrar-se em qualquer conforto habitual. É deste elemento surpresa que Fausto Fawcett elucidou muito claramente o caráter mutável do bairro em Copacabana Lua Cheia, um diário de ocorrências cotidianas registrado num período de sete dias, a partir de um apartamento de temporada alugado em 2001:

\begin{abstract}
...carta aberta jogada num mar de gente à deriva ou mais ou menos situada. Copacabana como um louco solo sagrado, Meca de adaptações, distorções, aceitações de tudo e de todos. Quantos lugares assim por aí? Vários. Mas só me interessa Copa porque aqui é o alto do meu farol humano. Farol de observação humana... Copacabana como solo sagrado. Como solo sagrado pode ser qualquer quintal em Sepetiba ou curral no interior. Baldio terreno em Berlim ou pedaço de Canyon. Solo sagrado é o que não falta no mundo, mas quem faz este solo sagrado é o emocional mentalizado por alguém ou por muita gente. E eu digo de novo Copacabana solo sagrado de toda a mundanidade e possibilidade. ${ }^{128}$
\end{abstract}

Esta condição de mundo, onde toda humanidade aqui se encontra, pois são todos lugares num só lugar, consolida o domínio da presença do corpo sobre os outros objetos. É esta condição de mundo nas suas complexidades que caracteriza tão bem o sentido de um lugar. Ferreira Gullar, eterno morador do bairro, expressou esta vivência extasiada pelas suas

\footnotetext{
128 Fawcett, Fausto. Copacabana Lua Cheia, série Coleção Sebastião. Rio de Janeiro: Dantes Editora,
} 2001, pp. 134-35. 
ruas. Para Gullar Copacabana é ao mesmo tempo íntima e desconhecida, e no meio das multidões anônimas do bairro ele a reconhece como única: ${ }^{129}$

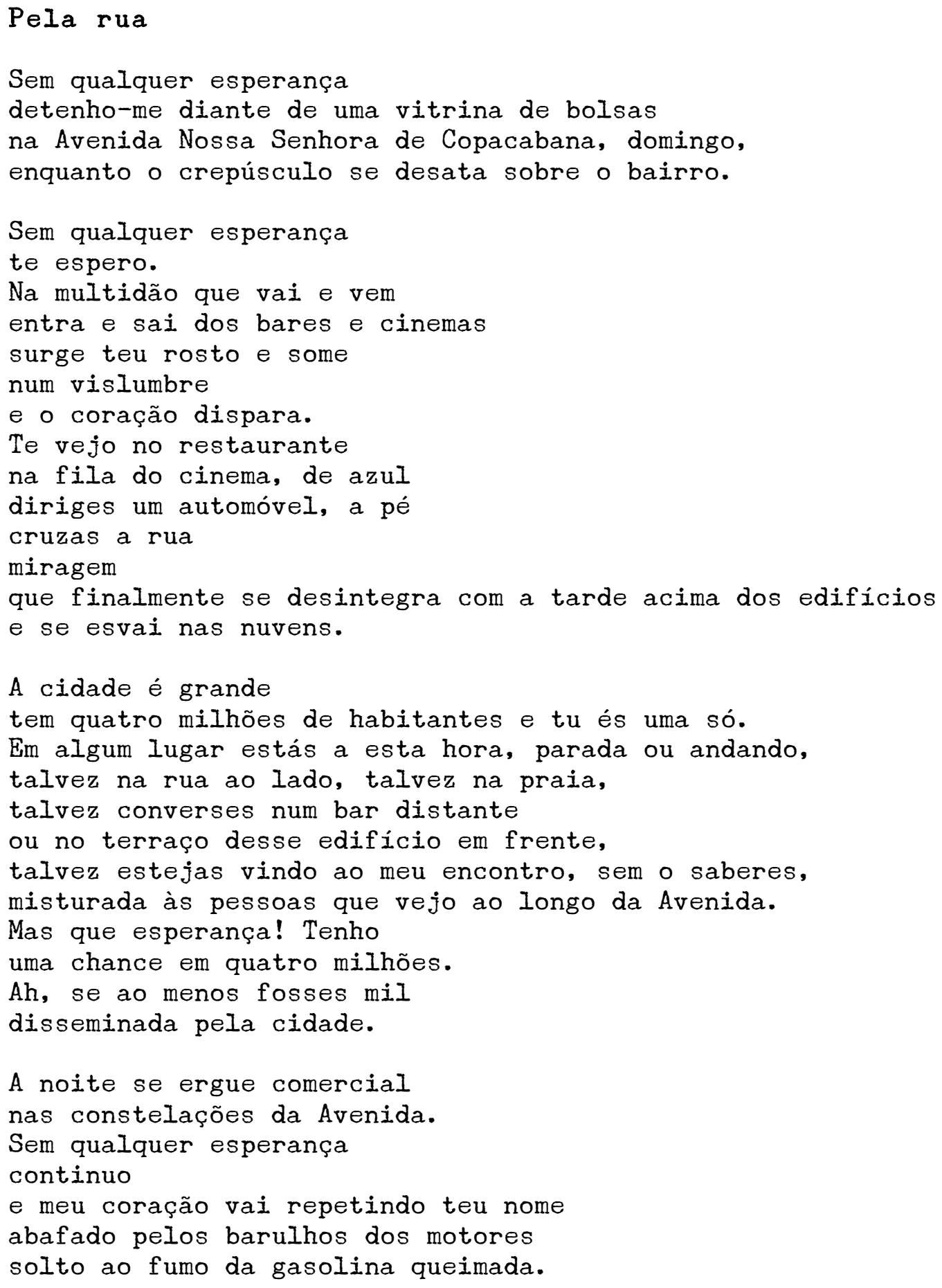

${ }^{129}$ Ferreira Gullar, “Pela rua”, Dentro da noite veloz. Rio de Janeiro: José Olympio, 1967. 
Gullar cria uma dualidade entre a possibilidade de encontrar a pessoa querida e o próprio personagem de Copacabana. Assim ele penetra pelos mistérios do bairro encontrando-a (pessoa-cidade) e se encontrando ao mesmo tempo. Este anonimato é provavelmente compartilhado por todos aqueles que habitam o bairro, residentes e visitantes. Em uma flutuação de gentes quase que constante Copacabana atrai um contingente significativo de turistas, alterando qualquer tentativa de aceitar o bairro de modo uniforme. Da mesma forma que a praia estica e contrai de maneira constante, assim ocorre no bairro. A capacidade de tal flexão urbana é devida a fatores infraestruturais: no que se diz à praia, a superfície de areia estendida mostra-se perfeita em sua forma, escala e situação para o acolhimento generoso de praieiros e banhistas, bem como o acolhimento da massiva participação de grandes eventos como o Réveillon, Carnaval ou concertos de música popular. A infraestrutura existente no recinto edificado do bairro flexiona-se pela grande presença de hotéis, albergues e apartamentos de temporada. Tal propensão às mudanças populacionais permitida tanto pela sua paisagem como pela sua arquitetura promovem o aspecto erótico dos encontros constantes de estranhos, que se dissimulam com a domesticidade dos moradores locais. Tanto o transito caótico do bairro como o circuito de pedestres intensificam os encontros, os olhares, as tensões, o colapso entre as diferenças.

Juntando-se a esse cenário, os morros e as suas favelas acrescentam uma nova camada de complexidade, agora aguçadas pela radicalidade topográfica da ocupação do território e da consequente penetração social das classes restringidas no meio urbano. Esta matriz que cruza os eixos sociais com os físico-estruturais foi desde a sua origem testada indefinidamente. A presença direta da natureza no interior desta urbanidade radical pode ser considerada como o elemento que alivia os atritos normais encontrados no plano do chão. Então temos a vista da praia para o mar, os morros que se mostram singelos nas entre-vistas dos prédios, as surpresas dos túneis ou das ladeiras que sobem como se fossem ao céu. O contraste entre essa exuberância natural e a violência da massa vertical edificada é que faz de Copacabana tão sedutora como lugar, como habitação, como casa, como paisagem de prazer. Em comparação, Ipanema é vista muito mais puritana, muito mais definida enquanto território de classe, e com feições naturais mais sutis, homogeneizando assim as maneiras de viver. ${ }^{130} \mathrm{O}$ desenvolvimento

\footnotetext{
${ }^{130}$ Não seria então o caso de se apontar o fato que os arrastões são muito mais predominantes em Ipanema/Leblon do que em Copacabana? Este fator homogeneizante de Ipanema, com densidade reduzida, arquitetura mais comportada em termos de escala e presença, não destacam as diferenças entre as classes, provocando assim o ímpeto alucinante das massas?
} 
urbano de Ipanema, posterior ao de Copacabana, permitiu um maior controle dos reguladores urbanos e da escala populacional o que gerou claramente uma estrutura de classes mais austera, mais exclusivista.

Copacabana pode ser considerada como um microcosmo da modernidade brasileira. O grande e rápido impulso para o seu desenvolvimento não só coincidiu com a própria história do desenvolvimento urbano do Brasil, mas também tornou-se um símbolo da própria modernidade. A intensa especulação imobiliária do bairro gerou naturalmente uma série de experimentações urbanísticas e arquiteturais, principalmente em se tratando de verticalização. Edifícios como o Richard ou o Shopping Copacabana foram protótipos de uma nova maneira de morar. Enquanto o Richard investiu no módulo pequeno da quitinete, mas em grande escala de unidades, aumentando radicalmente a densidade local, o Shopping Copacabana expandiu a então sofisticada estratégia urbana de uso-múltiplo.

Ao invés da concentração no objeto, esse universo onírico sugere novas relações da praia com outros processos da cultura contemporânea. Reentramos na cidade a partir da praia tendo nas práticas artísticas um mecanismo para se repensar os procedimentos de desenho, elegendo as intercepções entre as disciplinas para navegar com mais determinação através desta complexa condição. A investigação da praia vem de encontro a algumas questões que se confundem com a recente historiografia da nossa arte e arquitetura dos últimos quatro decênios, definida pela rejeição do arquétipo simbólico gerado pelo ideário pós-moderno, e a persuasão do ideal regional moderno, impactado pela influência de Brasília, Niemeyer e Artigas.

Uma contradição em relação à produção da arquitetura brasileira influenciou a produção pós-Brasília. A dualidade entre a forte tradição local de uma modernidade em sincronismo com os movimentos nacionais e a gradual influência das forças globais afetando a identidade cultural das novas gerações. Um debate se instaurou como resultado da grande penetração de capital nos anos 1980 e 90 e uma nova transformação das cidades. Foi instituído então uma dicotomia entre aqueles que heroicamente sintonizavam-se com o "projeto moderno brasileiro" e aqueles que insistiam em uma abertura total às forcas globalizantes. Criou-se então um quadro estigmatizado provocado pela grande persuasão da tradição moderna brasileira às novas gerações. Do outro lado, tínhamos uma produção artística de cunho experimental que alcançou enorme autonomia através da influência de artistas da geração do neoconcretismo, especialmente Lygia Clark e Hélio Oiticica, que, acima dos 
mandatos coletivos de um momento estético, nunca abandonaram seus próprios projetos pessoais, afastando-se de quaisquer dogmas, desenvolvendo assim um compromisso com a invenção pura. A nova Copacabana desenvolve-se durante este processo, denotando a própria narrativa da modernidade urbana do Brasil. Primeiro foi a descoberta do potencial da praia como escape da vida urbana, como novo território de prazer, fato este inaugurado com Sarah Bernhardt em 1886, quando em uma visita ao Rio para apresentar-se no Teatro Imperial São Pedro, banhou-se nas suas águas. Depois foi a criação dos grandes acessos urbanos no começo do século 20 a partir da abertura dos túneis. Em seguida foram as sequentes erupções de crescimento que fizeram a densidade populacional de Copacabana explodir no seu limite urbano, a firmação da metrópole. Com o congestionamento urbano do bairro e a transformação nos anos 1970, o alargamento da Avenida Atlântica e o projeto de Roberto Burle Marx vieram consolidar a vocação moderna de Copacabana.

\title{
II_ A praia de Copacabana e Roberto Burle Marx
}

\begin{abstract}
O jardim ordenado, nos espaços urbanos de hoje, é um convite ao convívio com a arte, à recuperação do tempo real da natureza das coisas, em oposição à velocidade ilusória das regras da sociedade de consumo. 0 jardim pode e deve ser um meio de conscientização de uma existência na medida verdadeira do homem, do que significa estar vivo. Ele é um exemplo da coexistência pacífica das várias espécies, lugar de respeito pela natureza e pelo outro, pelo diferente: o jardim é, em suma, um instrumento de prazer estético e um meio de educação. ${ }^{131}$
\end{abstract}

O projeto de Roberto Burle Marx (1970) redefiniu Copacabana através da expansão do espaço público da praia no encontro com o tecido urbano da cidade, ampliando a superfície do calçadão linear com o redesenho do tradicional mosaico português, mas incrementando consideravelmente a superfície para os pedestres, agora maior do que a superfície designada para o tráfego de carros. O aspecto de ícone que o calçadão de Copacabana assumiu pelos anos é só um exemplo do sucesso gradual do seu desenho desde os seus tempos de origem. A abertura dos túneis na passagem do séculos 19 para o 20 permitiu o acesso a um número maior de visitantes e trabalhadores, provocando o desenvolvimento do traçado urbano como conhecemos hoje. Na orla, o calçadão significou um momento de transição, de conexão entre a vida urbana e a paisagem da praia. Como peça de infraestrutura, o calçadão preservou o padrão gráfico das ondas do mar original. Na verdade o desenho não é de autoria de Roberto

\footnotetext{
${ }^{131}$ Roberto Burle Marx, Arte e Paisagem (conferências escolhidas). São Paulo: Editora Nobel, 1987, p. 34.
} 
Burle Marx. A história do famoso padrão não é clara, pois podemos identificá-lo em outros lugares como no pavimento da Praça do Rossio em Lisboa, concebida no século 19, representando o encontro das águas do Rio Tejo com o Oceano Atlântico, e também no Largo de São Francisco, em Manaus, em 1901. Por volta da mesma época, o padrão das ondas foi também identificado em imagens históricas da moda de Zanzibar. Mas talvez o registro mais surpreendente e mais antigo do famoso padrão é a presença das ondas em uma bandeira da pintura bélica de Paolo Ucelo Micheletto da Cotignola engaja nas batalhas, produzida por volta de 1450. O aspecto original do desenho de Burle Marx foi a mudança de direção do padrão, posicionado agora paralelo às ondas do mar, o aumento da sua escala, e o alongamento do desenho das ondas. A intuição de Burle Marx em valorizar um elemento já ícone transformou o calçadão de Copacabana em um dos artefatos de desenho urbano mais fluentemente reconhecíveis. Agora as ondas conversam em paralelo com as próprias ondas do mar, uma conversa direta entre um elemento infraestrutural (o calçadão) com um elemento da paisagem (as ondas), aproximando a cidade para dentro do mar e o mar para a cidade.

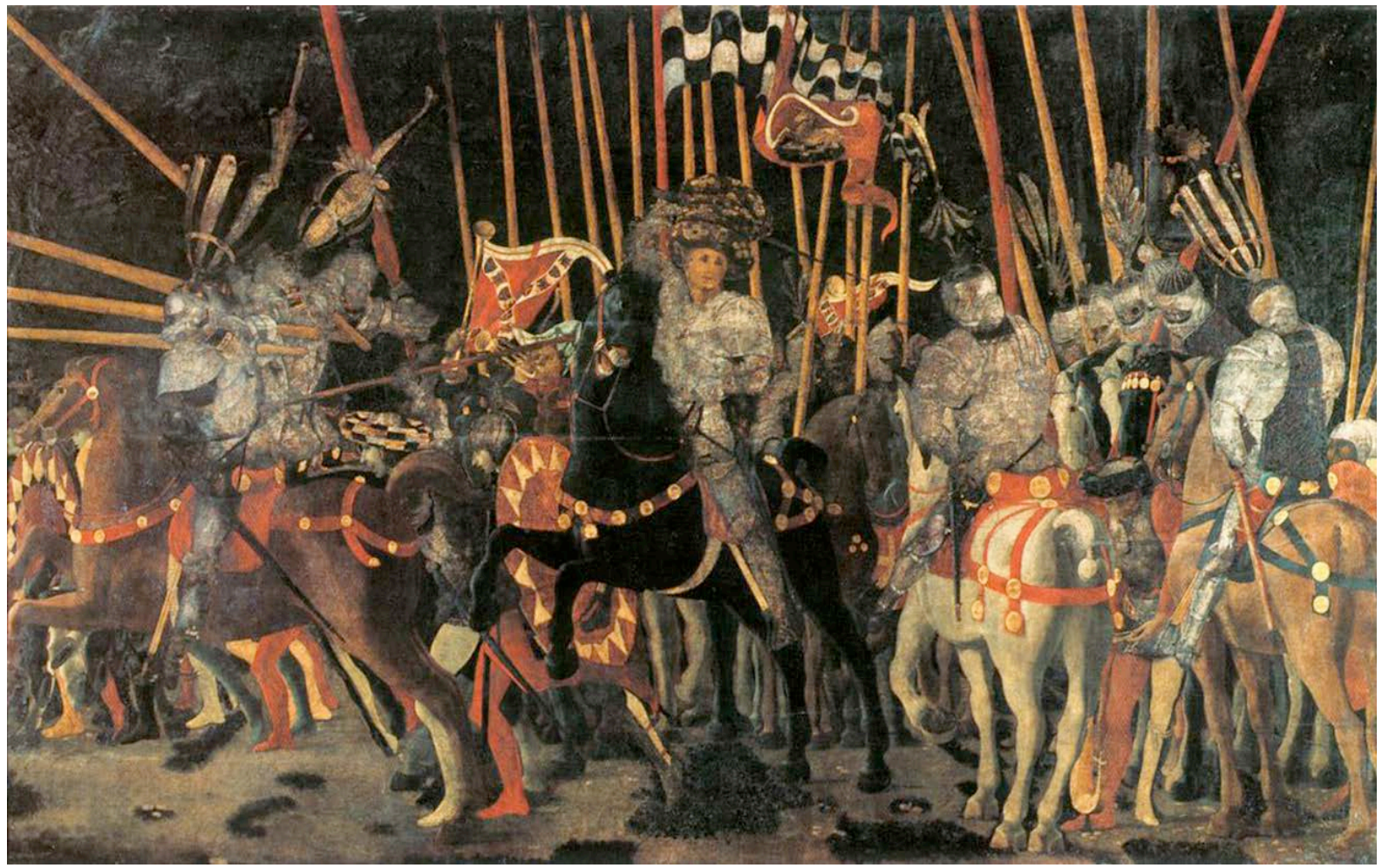

Paolo Ucelo, Micheletto da Cotignola engaja nas batalhas (cerca de 1450) 


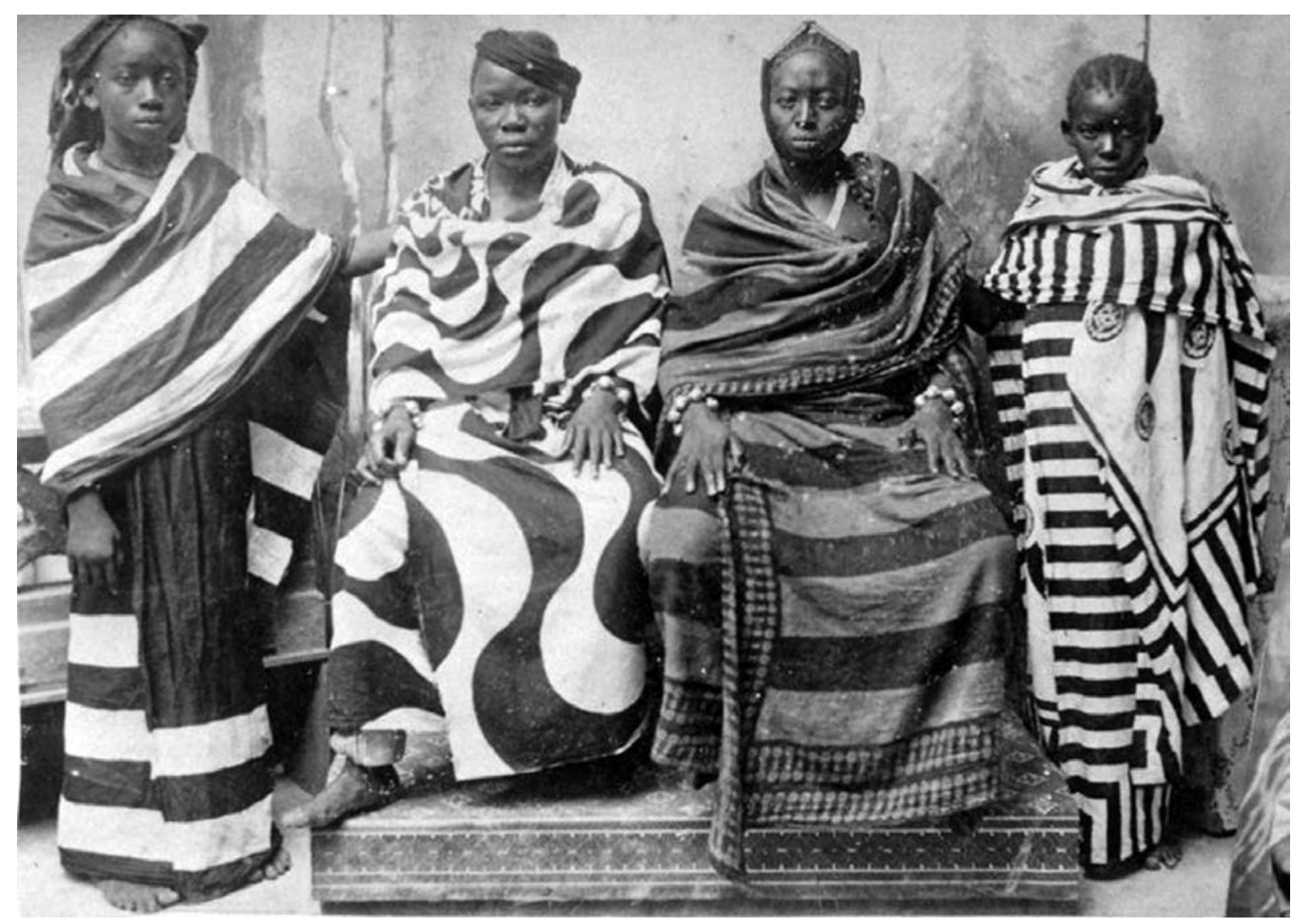

Moda em Zanzibar (século 19)

Outro aspecto infraestrutural que permitiu a ampliação de usos e experiências da orla de Copacabana foi o alargamento da superfície da praia e da Avenida Atlântica. A ampliação da área de areia permitiu novos usos como mais área de lazer, jogos de futebol, concertos, etc. A ampliação da avenida permitiu também a intensificação dos transportes públicos como a implementação do sistema de esgoto do bairro, protegendo-o também das ressacas. Se observarmos com mais cuidado o papel do calçadão de Copacabana na articulação total do território urbano, ele compartilha o seu sucesso com outros aspectos menos evidentes, mas de importância semelhante, no desenvolvimento desta paisagem urbana. Imaginando um corte transversal indo do mar até a fachada dos edifícios, mapeamos esses aspectos da seguinte forma:

1. Céu aberto: o sentido de magnitude espacial quando se chega e se fica na praia é intensificado pela amplidão do céu, produzindo um escape espacial e psicológico, contrastando com a densidade exagerada do bairro.

2. Horizonte: o mirar o horizonte infinito cria a sensação de olhar-se a si mesmo, de encontrar-se num modo reflexivo. 0 horizonte vira um "palco do espelho" lacaniano, lugar onde tomamos consciência do eu. 
3. Mar aberto: a amplidão do mar e do céu produz a percepção de um sentido de lugar: o Atlântico está aqui, a África está ali, então estamos aqui, sabemos aonde estamos. Assim a amplidão do mar assume a escala do mundo - estamos em Copacabana, mas também no planeta.

4. Zona de natação: aqueles que passam as ondas encontram uma zona mais calma, ideal para o nado prolongado, mas é uma zona que tem que ser negociada com outras pequenas navegações como motos aquáticas e lanchas de resgate.

5. A quebra das ondas: oferecem um dispositivo natural de entretenimento: pular, furar, pegar, surfar, etc. Esportes como o surfe ou o bodyboard são praticados. As ondas são também a forma mais enfática de um soundscape, um sompaisagem no fundo da trilha sonora da praia.

6. Mar raso: zona ideal para relaxar conversando em pé, refrescar ou para diversão infantil. É também uma zona de transição entre a área mais relaxada da faixa de areia e o mar, provocando um cruzamento no tráfego de pedestres.

7. Faixa de areia imediata ao mar: zona ideal para o caminhar, de grande circulação entre pedestres e corredores, criando uma "rua interna" em toda extensão da praia. Zona favorita para altinha, frescobol ou construir castelinhos de areia.

8. Guarda-sóis: área de mais densa ocupação devido à sua proximidade ao mar, mas ainda com areia fofa e branca: conforto ideal. Área favorita para a circulação de vendedores ambulantes o que provoca a maior densidade de trocas comerciais.

9. Barraquinhas: localizadas imediatamente atrás da faixa dos guarda-sóis, oferecem serviços de bebidas, de aluguel de cadeiras ou guarda-sóis. Algumas barraquinhas também oferecem serviço gratuito de chuveiro, acionado por bomba.

10. Extensão de areia fofa e branca: equidistante entre o mar e a avenida. Devido à sua distância do mar esta área é a menos ocupada devido às suas altas temperaturas a sol aberto, o que abre espaço para campos de futebol e outros eventos. É também a área menos densa.

11. Faixa de palmeiras + iluminação: zona de transição entre a superfície da praia e a cidade. Área popular para o vôlei e futevôlei. É nesta zona aonde os postos de serviços estão localizados. Frequente ponto de encontro ao longo da mureta do calçadão.

12. Quiosques: em Copacabana os quiosques tem sido remodelados gradualmente, projeto do arquiteto Índio da Costa. Os novos quiosques criam uma área de transição entre o calçadão e a areia, oferecendo estruturas básicas para a prestação de serviços, um paisagismo integrado e a utilização do subsolo da areia para a implantação da infraestrutura de banheiros.

13. Calçadão: área popular com os andantes, corredores e frequentadores dos quiosques. Também intensamente utilizada por camelôs. 0 calçadão é a superfície mais intensamente ocupada e movimentada.

14. Ciclovia: circulação de bicicletas mas também ocupada por corredores. Copacabana é o bairro da Zona Sul com a maior utilização de bicicletas, aonde 60 mil viagens são feitas diariamente no bairro, das quais, 12 mil são para entrega.

15. Avenida Atlântica: circulação de automóveis e ônibus na direção centro.

16. Faixa mediana: em Copacabana é muito mais larga que o normal, chegando a 20 metros, o que permite a presença de postos de gasolina ou usos alternativos como feirinhas e exposições ao ar livre na larga superfície central.

17. Avenida Atlântica: circulação de automóveis e ônibus na direção zona sul. 


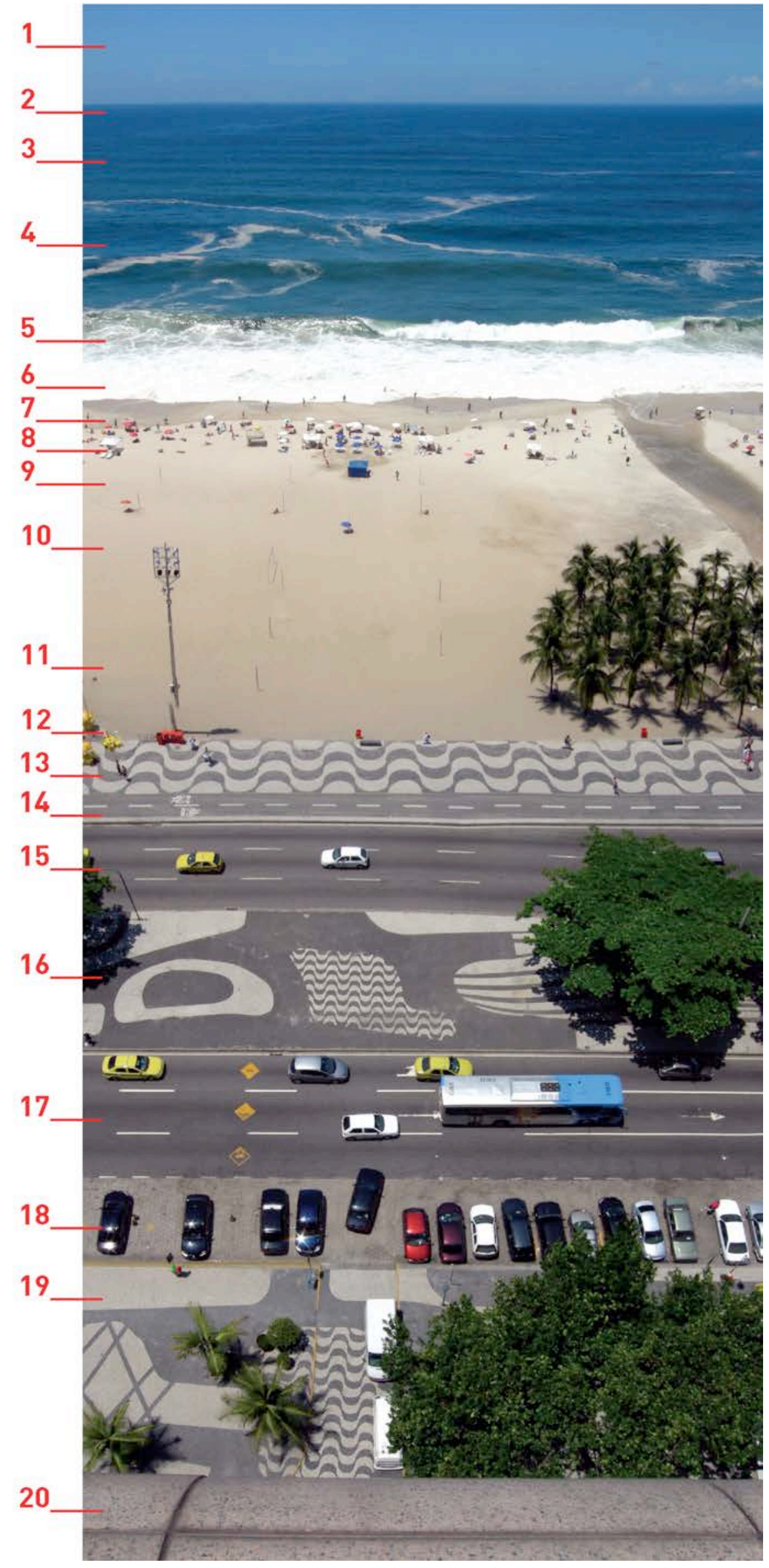

Copacabana (corte) 
18. Estacionamento: permitindo o posicionamento de veículos a 90 graus, o que acelera o estacionar, diminuindo o congestionamento nas zonas de tráfego.

19. Calçada: com uma dimensão muito mais profunda do que uma calçada normal, serve como área de acesso aos edifícios, circulação de pedestres, área de entrega para caminhões, e também como um parque linear, haja vista a sua generosa vegetação e tratamento da superfície com os desenhos de Burle Marx.

20. Fachada dos edifícios: além de servirem como perímetro de proteção aos seus habitantes funciona perceptivamente como "moldura" para aqueles que frequentam a orla - um verdadeiro catálogo da modernidade carioca.

Cada uma destas 20 faixas designam uma maneira de ocupação, uma fisiologia paisagística diferenciada, um uso particular, uma peça de infraestrutura, uma modificação na superfície, um comportamento, um fenômeno perceptivo, uma atividade, uma ação, uma troca, uma experiência única. Cada uma das faixas assumem uma qualidade de tempo/velocidade devido às suas respectivas materialidades: superfícies duras (mosaico português, asfalto) referem-se a velocidades rápidas enquanto superfícies moles (areia, água, vegetação) referem-se a atividades mais lentas. Nota-se a intercalação entre elas (mole/dura/mole > areia/mosaico português/vegetação). Às vezes, no caso de Burle Marx, tal condição aparece simultaneamente, o que Farès El-Dahdah se refere como "multiplicidade contínua”, o que caracteriza a temporalidade de um espaço e a sua instabilidade e flutuação, contradizendo as qualidades convencionais do edifício que são imutabilidade e estabilidade. ${ }^{132}$ Esta multiplicidade contínua é revelada em Copacabana, por exemplo, no padrão gráfico do pavimento do calçadão, da faixa mediana, e da calçada junto aos prédios, integradas às outras demais faixas: onde encontramos uma superfície dura ela mesma traz aspectos "moles" da sua articulação estética (curvas, pinturas, desenhos), ou mesmo na aglutinação entre materiais de construção e plantas, e na combinação de elementos verticais e horizontais. Esta amalgamação entre uma sensibilidade masculina e outra feminina, tão característica do trabalho de Burle Marx, não só cria a variação necessária para todo espaço público efetivo, como também acentua o aspecto erótico de Copacabana. No seu desenho, o arquiteto interrompe a grade regular da geometria do bairro e também a imposição radical da linha das fachadas dos edifícios pelo seu traço sensual, criando assim um contraponto que é oferecido àquele que observa essas superfícies do alto dos prédios e àquele que caminha sobre ele.

\footnotetext{
${ }^{132}$ Farès El-Dahdah, “Unstable Landscapes”, Roberto Burle Marx: The Modernity of Landscape. Paris: Institut français d'architecture/Actar, 2011, p. 40, tradução nossa.
} 


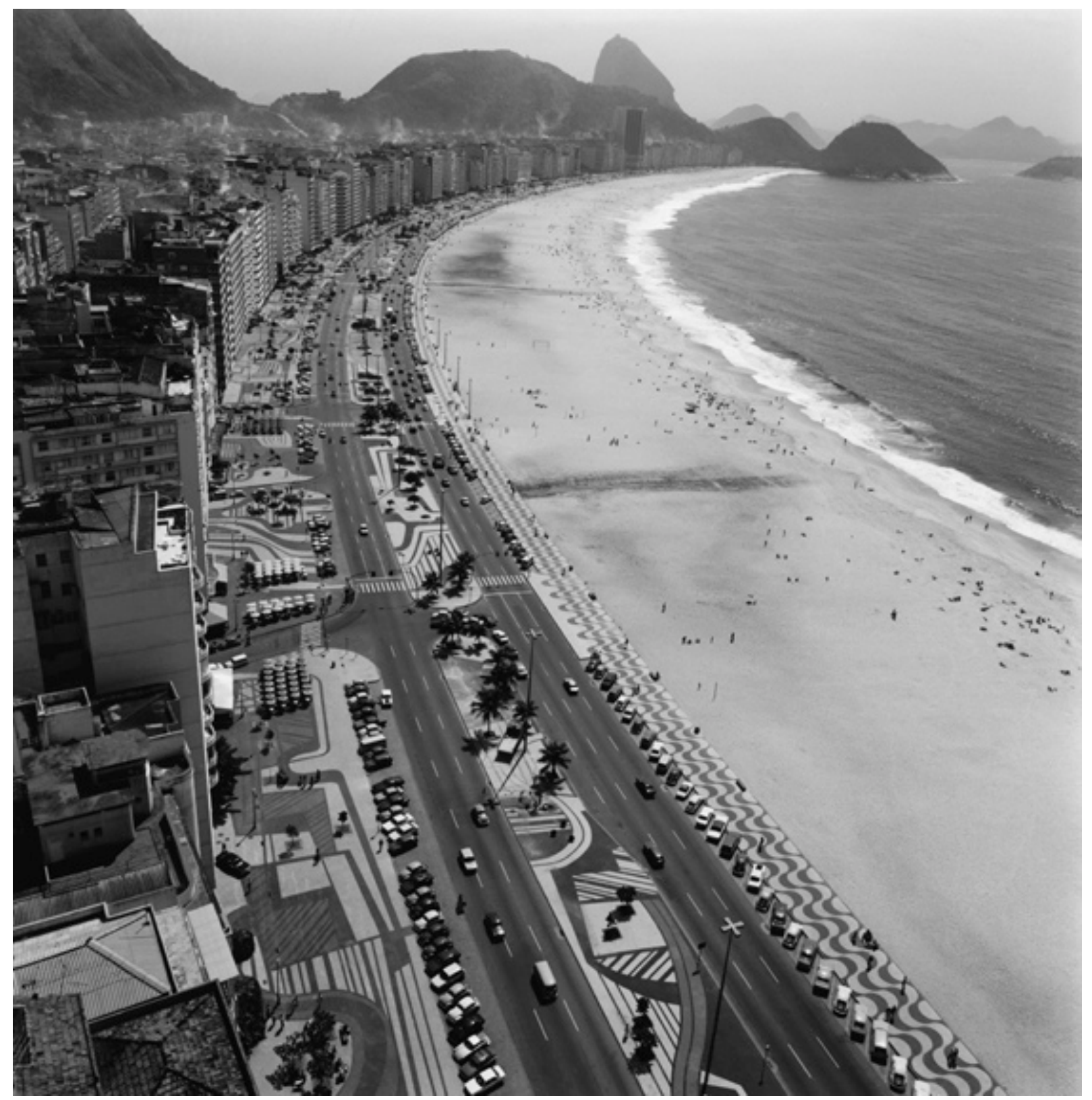

Marcel Gautherot, Copacabana (1975)

Notamos que esta multiplicidade contínua não ocorre somente no espaço físico de Copacabana, ou nos gestos livres de Burle Marx, mas, como Caymmi retratou tão bem em Sábado em Copacabana, a multiplicidade do lugar é também parte do seu cotidiano, das experiências daqueles que habitam o lugar: trabalhar toda a semana / programa pra esta noite / lugar para encontrar / passear à beira-mar / num bar à meia-luz / jantar depois de dançar / lugar para se amar. Então, "fazer um programa em Copacabana" se refere a todas as possibilidades que o lugar oferece em termos de "programas" no seu significado duplo: algo para se fazer e tudo o que pode se passar num determinado lugar. Os "programas" em Caymmi são circunscritos a aqueles providos de prazer e amor. A implicação aqui é que tanto 
a praia como o bairro oferecem uma enorme gama de possibilidades de habitação e vida, infinda mesmo, pois nas palavras do poeta essas são apenas a expressão de um só, quando sim existem muitos, milhares que ativam estes espaços a todo momento, e das maneiras mais diversificadas, numa intensa riqueza urbana.

Todas essas características de cada uma das faixas mapeadas acima, e perfeitamente interligadas, coexistem para prover na sua totalidade a experiência integral da praia, mais especificamente aqui, a experiência da praia de Copacabana. A adaptação da praia dentro do conjunto ambiental urbano, com todas condições coexistindo, constituem praiapaisagem: uma rede complexa de relações físico-ambientais, humano-culturais, urbano-infraestruturais intencionando "compor" um espaço público total. A prática artística aqui evidencia-se como estratégia na busca desta totalidade. A composição de uma superfície para Burle Marx assume uma afinidade muito próxima a do artista pintor que confronta uma tela branca:

\begin{abstract}
Em relação à minha vida de artista plástico, da mais rigorosa formação disciplinar para o desenho e a pintura, o jardim foi de fato, uma sedimentação de circunstâncias. Foi somente o interesse de aplicar sobre a própria natureza os fundamentos da composição plástica, de acordo com os sentimentos estéticos da minha época. Foi, em resumo, o modo que encontrei para organizar e compor livremente o meu desenho e pintura, utilizando materiais menos convencionais. Em grande parte, posso explicar através do que houve em relação à minha geração, quando os pintores recebiam o impacto do cubismo e do abstracionismo. A justaposição dos atributos plásticos desses movimentos estéticos aos elementos naturais constituiu a atração para uma nova experiência. Decidi-me a usar a topografia natural como uma superfície para a composição e os elementos da natureza encontrada - minerais, vegetais - como materiais de organização plástica, tanto e quanto qualquer outro artista procura fazer sua composição com a tela, tintas e pincéis. ${ }^{133}$
\end{abstract}

No caso de Burle Marx é a sua capacidade de compreender o valor do jardim na sociedade que o distancia de qualquer formalismo. Na sua visão o jardim público reside entre a experiência estética e a educação, passando pelas mais variadas experiências humanas, adquirindo assim a responsabilidade de prover acima de tudo uma vida rica para àqueles que o experimenta. Na sua disponibilidade em produzir a complexidade de uma vida rica através de um jardim público Burle Marx propõe uma aproximação com as artes. Utilizando de procedimentos vindos da sua prática artística, Burle Marx cria uma totalidade dentro da experiência do jardim através de progressivas vivências em momentos distintos mas dentro de

${ }^{133}$ Cesar Floriano, "Passeio de Copacabana: uma referência da arte pública de Roberto Burle Marx", p.4. Artigo apresentado no $8^{\circ}$ Seminário Docomomo Brasil (2009). Disponível em: <http://www.docomomo.org.br/seminario\%208\%20pdfs/159.pdf>. Acesso em: 11 de janeiro de 2014. 
uma continuidade sem emendas, com por exemplo, no andar, no dirigir, no pausar, no atravessar, no chegar e no partir - a cada momento existe a possibilidade de passar por uma experiência sensorial rica e diferente, ininterruptamente, e sempre informada pela intenção poética.

Burle Marx mapeia assim o espaço público refletindo rigorosamente cada metro quadrado, não mais como uma pintura, mas como vida na sua totalidade. De certa forma a estratégia que propomos aqui assemelha-se à de Burle Marx, no sentido de compreender que o espaço público supera na sua constituição qualquer formalismo pictórico. Uma tradução multidimensional de Copacabana, agora apreendida pela experiência da praia, sugere então uma série de dispositivos de desenho que potencialmente podem ser aplicados a qualquer espaço público: variação material, qualidades distintas de tempo, diferentes áreas de atividades, ocupações simultâneas, sobreposição de experiências diferentes de um dia para o outro, ocupações diferentes dependendo da hora do dia ou do clima, desenhos que conduzem o corpo e o olhar, e tantos outros aspectos que constituem um verdadeiro e rico espaço público. Copacabana com seu leque de condições ambientais, urbanas e culturais serve como um modelo de concepção urbana engajada. Devido à sua reconhecida qualidade como ambiente urbano total e entendida simultaneamente como infraestrutura, paisagem e arquitetura integrados à uma estrutura social complexa, a Copacabana de Burle Marx propõe um novo campo de interação urbana em um espaço público.

\title{
III_O espaço público de Copacabana
}

\begin{abstract}
É muito simples: Basicamente, há muito tempo temos um sistema que não funciona para a maioria das pessoas do planeta e algumas pessoas acham que está na hora de tentar mudá-lo. É só isso. Os membros do Occupy Movement aberta e humildemente reconhecem que não têm todas as respostas e, na verdade, ninguém tem. 0 problema, na visão deles, é grande e profundo, e precisamos de muita ajuda para encontrar soluções, mas o primeiro passo é se reunir para falar, dialogar, e aprender. Shad, rapper de Vancouver ${ }^{134}$
\end{abstract}

O status ícone da praia de Copacabana serve às vezes para aliviar ou encobrir a realidade social dos espaços públicos do Rio de Janeiro. A sua exuberância certamente contribui para descartar o fato de que Copacabana, e por extensão todas as praias da zona sul do Rio de

\footnotetext{
${ }^{134}$ Shad, "What is the Occupy Movement?", The Vancouver Sun, (21 de novembro de 2011). Disponível em: <http://blogs.vancouversun.com/2011/11/21/shad-what-is-the-occupy-movement $>$. Acesso em: 11 de janeiro de 2012.
} 
Janeiro (e do resto do Brasil urbano), são também territórios de conflito, de luta, de negociação no processo de compartilhamento das nossas cidades como foi observado em Barravento. A conquista do morro, por exemplo, revela a distribuição das vistas, pois ao mesmo tempo que os privilegiados moradores da Avenida Atlântica usufruem da vista ao mar, assim alguns moradores das favelas Chapéu Mangueira, Babilônia ou Cantagalo também a possuem. Mas também vemos o caráter experimental do bairro de Copacabana, pois na sua rápida história muito se desenvolveu espontaneamente, incluindo as favelas. Esta visão compartilhadora do território sustenta uma perspectiva humanista da possibilidade de negociação do solo urbano. Na praia em si, como vemos, tais negociações ocorrem a cada minuto, a cada instante, a cada dia que o sol ilumina as relações entre as pessoas. Há muito sabemos que estes processos de negociação do território não mais são exclusividade de governos ou técnicos, urbanistas ou arquitetos. Paulo Mendes da Rocha articula esta visão com grande afinidade em relação à condição de Copacabana:

\begin{abstract}
A técnica tem que ser vista como um recurso, como uma estratégia para a resolução de problemas - problemas decorrentes desses desejos, problemas criados que precisam ser resolvidos, e então a coisa é feita. Não podemos aderir a uma visão corporativa de arquitetura, onde a nossa identidade/mercadoria como criadores demanda de nós: arquitetos, isso é o que somos! 0 homem é que é o arquiteto e a cidade cria-se em diálogo com ele. Alguém certa vez descreveu com grande beleza, em uma visão literária destas reflexões: "a maior expressão do urbanismo no Brasil são as favelas" - o desejo de viver como você quer. Especialmente no Rio onde isto é mais marcante, a especulação abandonou os morros que são difíceis de construir, e que estão agora protegidos. Mas no começo não era esse o caso. As encostas estão no topo da cidade, e para que as pessoas habitam esta riqueza elas se instalam ali. Essas favelas que sobem as montanhas com todas aquelas pequenas luzes à noite, é tudo muito bonito. A favela é uma manifestação da consciência sobre as virtudes da urbanização como forma de civilização. ${ }^{135}$
\end{abstract}

Fica aqui esclarecido por Mendes da Rocha que o desejo da cidade é o desejo humano coletivo. Através da técnica e da espontaneidade, o melhor é atingir o resultado mais perfeito dentro da complicada equação de diferenças. Ao mesmo tempo que o reconhecimento dos conflitos, das desigualdades, das incoerências são identificados, existem no âmbito do desejo público a intuição de deliberar tais processos pela informalidade, espontaneamente, no dia-adia, e pelos próprios atores que ativam constantemente os espaços públicos. Existe uma atitude diferente na conduta das pessoas em relação ao espaço público no Rio de Janeiro, especialmente em Copacabana, haja vista a frequência em que achamos, por exemplo, coisas

\footnotetext{
${ }^{135}$ Paulo Mendes da Rocha, “São Paulo: a New Geography”. Eduardo Aquino e Karen Shanski. Complex Order: Intrusions in Public Space. Winnipeg: Plug In Editions, 2009, pp. 136-37.
} 
em árvores, ou ocupações espontâneas nas calçadas. Aqui a árvore ou a calçada não são mais simples ornamento, sombra, ou piso para circulação mas transformam-se em infraestruturas urbanas para outras rotinas. Em se tratando dos processos evolutivos dos espaços urbanos inevitavelmente atingidos pelos fatores da escala global de troca observamos uma certa resistência nos espaços urbanos brasileiros, tão influenciados pela informalidade e pela falta de critérios claros em relação à instrumentalidade do urbanismo como forma técnica de ação.

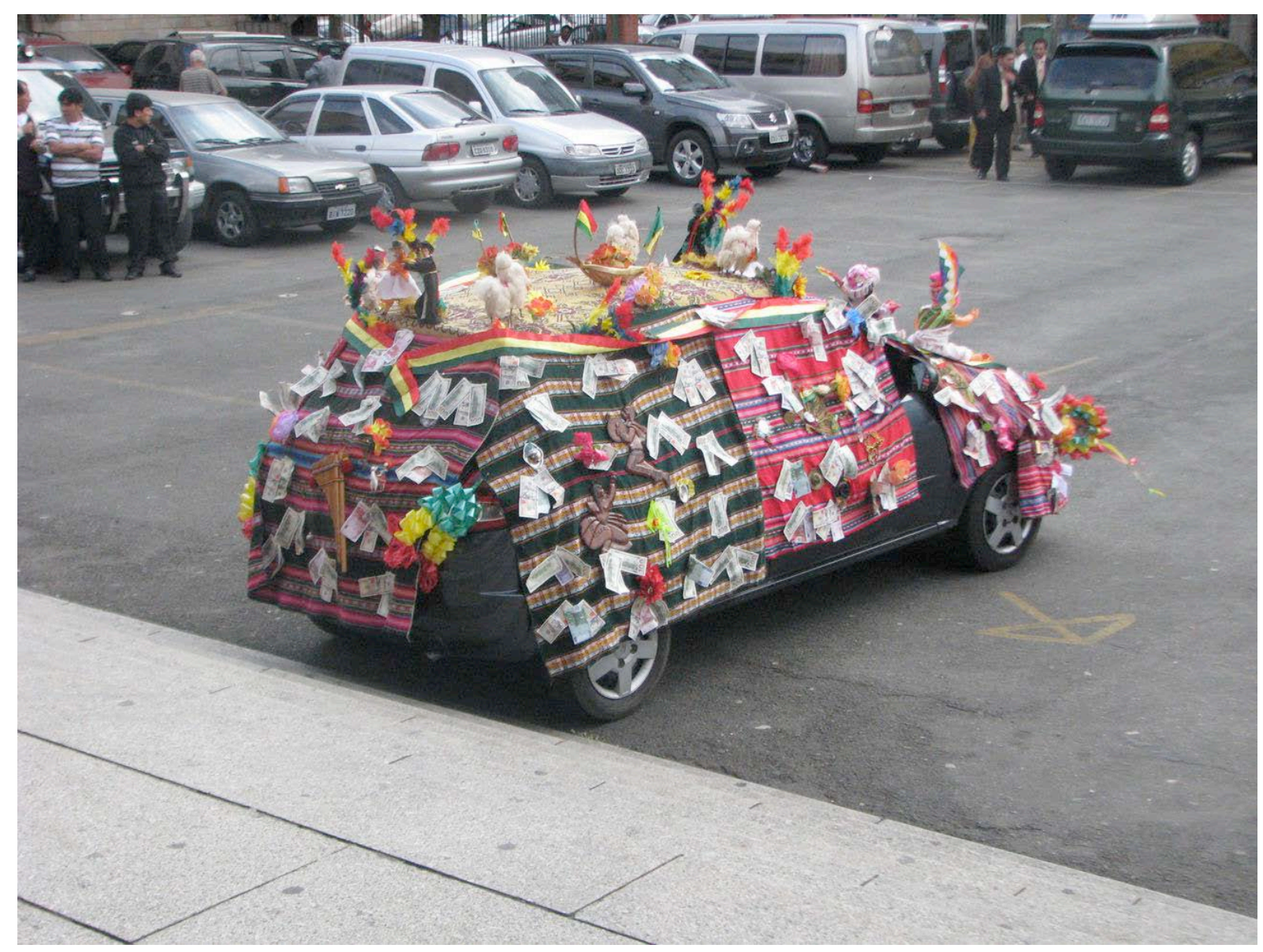

Espaço compartilhado em Copacabana

A fragilidade do movimento dos “ocupas” no Brasil (Occupy Wall Street / Occupy

Movement $)^{136}$ se deve às maneiras informais e frequentes pelas quais o espaço público é usado: O controle privado do espaço público escapa mais frequentemente da autoridade, para assim ser usado como infraestrutura social compartilhada, enquanto em outras cidades do mundo o movimento fez mais sentido, pois significou um gesto político pontual pelo contraste das suas

\footnotetext{
136 "Movimento dos ocupas" foi originalmente cunhado por João Alexandre Peschanski no jornal Juízes para a Democracia, n.55, set.-nov. 2011.
} 
ocupações com o significado dos espaços que foram ocupados. O movimento dos "ocupas" em Copacabana é uma atividade cotidiana ubíqua e entre-classes.

A expulsão recente dos “ocupas” dos espaços públicos em todo o mundo através da aplicação de força pelos órgãos locais de controle provocou uma reflexão sobre permanência do movimento e do seu futuro. O movimento dos “ocupas" foi inicialmente sugerido pelos organizadores da revista ativista Adbusters de Vancouver como forma de reagir contra a dominação dos mercados financeiros, gerando divergências crescentes entre os que têm controle do capital e os que dependem dele para sua sobrevivência. Nesse processo, o que se tornou aparente foi a revelação de que os territórios urbanos designados como "públicos" são de fato controlados pelo capital, como o mundo financeiro em si é controlado pelo capital. Além das consequências do movimento para a crítica das diferenças sociais baseadas em riqueza, uma verdadeira discussão sobre o espaço público se sucedeu.

No caso de Copacabana e do seu espaço público, novas inserções informais nos tecidos urbanos existentes e por entre as suas arquiteturas é constante, fazendo do bairro um microcosmo das condições urbanas generalizadas no Brasil. A freqüência com que encontramos ocupações de caráter informal no bairro é a evidência da proximidade de tais comportamentos com a cultura local. Estas ocupações demonstram o jeito carioca de ser, constituindo assim parte do imaginário das suas gentes e lugares. Ao invés de impor uma nova condição forçada para um lugar, característico dos espaços públicos controlados exclusivamente pelo capital, como é o caso de Wall Street, em Copacabana elas ocorrem e desaparecem sem alterar a rotina dos espaços públicos. Imaginamos que a complexa questão da ocupação do espaço público da praia de Copacabana é um modelo da maneira como as pessoas ocupam espaços públicos no Brasil urbano em geral. Quando nos dirigimos para as áreas mais densas do bairro estas manifestações se intensificam, mas tais demonstrações afetam também diretamente as dinâmicas no âmbito da praia.

Para mapearmos tais situações, usamos um método semelhante ao coletivo de artistas Temporary Services. Temporary Services é um coletivo de artistas formado por Brett Bloom, Marc Fischer, and Salem Collo-Julin, com base em Chicago, Copenhaguem e Filadélfia. Eles colaboram em projetos de arte, eventos públicos, publicações e exposições desde 1998. Seus projetos públicos são de natureza temporária, efêmera e operam fora das categorias convencionais ou oficialmente sancionadas. O grupo afirma que o seu desejo é de não dar preferência a qualquer tipo de atividade ou objeto de arte, ou qualquer audiência, trabalhando 


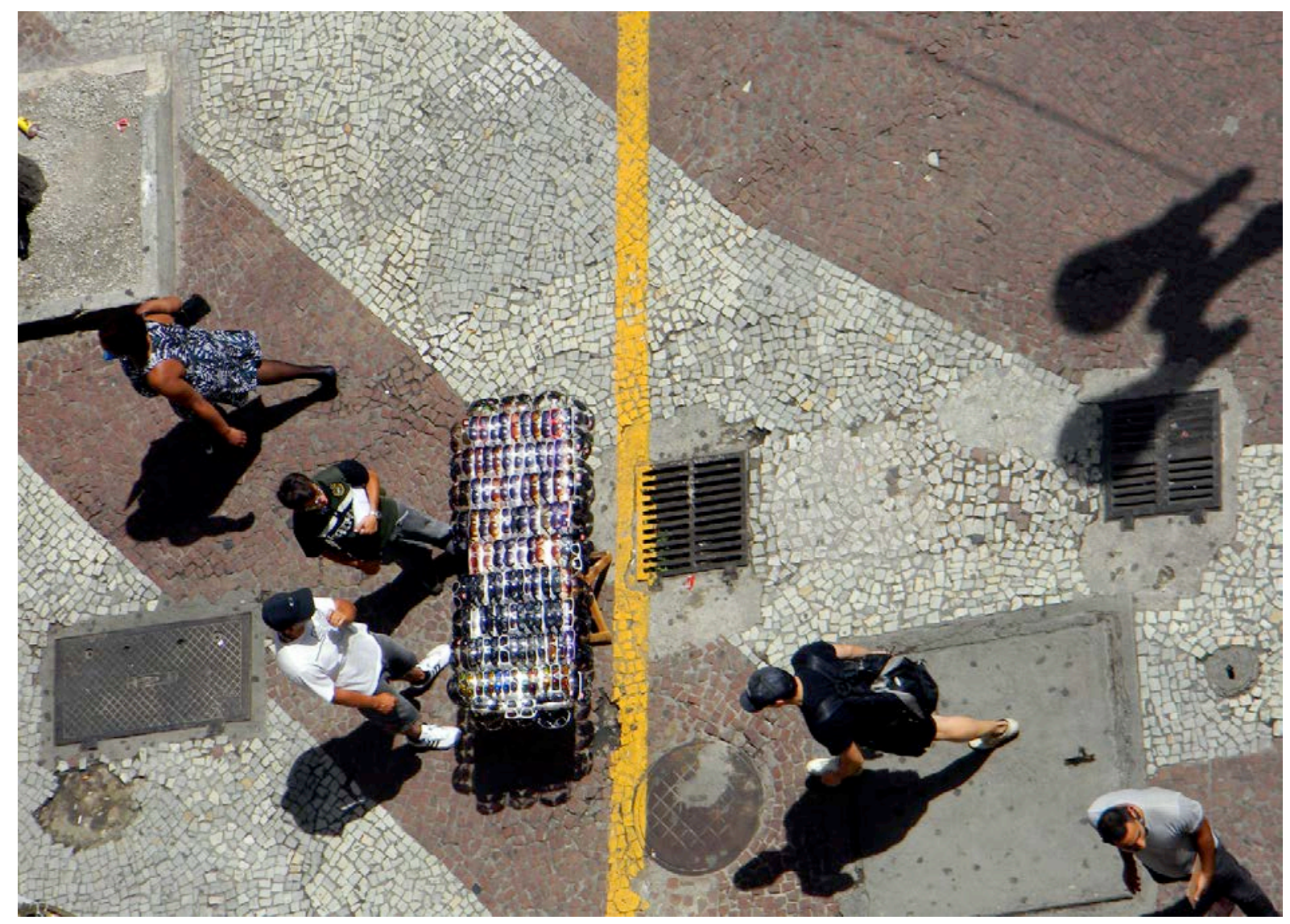

Ocupação informal em Copacabana

contra o vínculo construído entre estética e ética. Eles vêem arte como ativismo e praticam nas tradições do situacionismo. Desde 1998, eles desenvolveram um interesse ativo na cultura vernácula encontrada nos espaços públicos, desenvolvendo um grande arquivo de fenômenos peculiares fotografados ao ar livre, nos espaços públicos de várias cidades. ${ }^{137} \mathrm{~A}$ maioria das situações são ações informais que resgatam o espaço público para um novo partido. $\mathrm{O}$ trabalho resultante discorre sobre a variedade de modificações e invenções que as pessoas criam em público utilizando-se da informalidade. De memoriais de beira de estrada a barreiras repentinas, tais situações improvisadas alteram espaços comuns compartilhados para atender às suas próprias necessidades, ou até mesmo deixar aberrações artificiais e naturais correrem soltas. O resultado é um novo tipo de espaço público com momentos criativos e inspiradores que desafiam a vocação original dos espaços urbanos. Temporary Services descreve assim esses fenômenos:

\footnotetext{
${ }^{137}$ O projeto é denominado Public Phenomena (Fenômeno Público).
} 
Essas modificações e inserções provocam uma gama informal, acidental, intencional e/ou política. Há um interesse e somos inspirados pelas formas que as pessoas mudam o espaço compartilhado para além da sua forma ou intenção originais. Através do acúmulo de evidências de cada fenômeno, podemos perceber o maior controle lou falta de controle) dos processos naturais e humanos. Um novo espaço "público" é criado quando todo mundo parece estar fazendo a mesma coisa, ainda que privada. Ao investigar vários exemplos e variações destas coisas, uma imagem clara do comportamento humano emerge. Essa [pesquisa] nos diz muito sobre o nosso meio e é algo que podemos aproveitar e compartilhar com os outros para ganhar a sua experiência e discernimento. ${ }^{138}$

A descrição acima pode ser aplicada diretamente à fenomenologia da praia pois diariamente tais processos ocorrem no seu espaço. Mas no caso de Copacabana, no âmbito do bairro em si, longe da praia, esses comportamentos também ocorrem - e com uma frequência mais significativa do que em outros bairros, como por exemplo, Ipanema. Em Copacabana, devido ao menor controle do espaço público pelo capital, alterado pela grande massa populacional que preenche seus espaços constantemente, o vocabulário da ocupação urbana informal se expande, enfatizando as situações particulares do bairro. É claro que todos nós conhecemos estas formas de ocupação, pois são familiares num contexto muito maior, observadas em todo Brasil metropolitano. No caso das observações feitas em Copacabana, elas serviram como base para uma nova conscientização, um rastreamento sistematizado, ratificando esta sua característica modificadora do território tão enraizada na sua história das suas complexidades sociais, e desde a fundação da cidade formadora cultural da conduta carioca. $^{139}$

Como a informalidade do espaço brasileiro tem enorme aceitação cultural, a sua ocupação irregular passa desapercebida ou é intuitivamente perdoada. Segundo Saskia Sassen, ocupar é re-fazer temporariamente as lógicas muitas vezes profundamente antidemocráticas de poder, redefinindo o papel dos cidadãos. Tal papel se enfraquece depois de décadas de crescente desigualdade e injustiça. ${ }^{140}$ Em Copacabana, este cenário é reforçado pela tolerância que aparenta surgir da compreensão coletiva de uma história de desigualdades e injustiças, visível por todo lado no espaço urbano, tolerância esta rompida pelos arrastões, por

\footnotetext{
138 TEMPORARY SERVICES, Public Phenomena: Informal Modifications of Shared Spaces. Temporary Services: Chicago, 2005.

${ }^{139}$ Este trabalho foi realizado em colaboração com os alunos do estúdio Superficial II, da Faculdade de Arquitetura da Universidade de Manitoba em janeiro de 2012.

${ }^{140}$ Saskia Sassen, "Imminent Domain: Saskia Sassen and Hans Haacke on the Spaces of Occupation". New York: Art Forum, janeiro de 2012. Disponível em: <http://artforum.com/inprint/id=29814>. Acesso em: 10 de abril de 2012.
} 
exemplo. ${ }^{141}$ Ao ocupar o espaço público, aqueles que tradicionalmente não detêm o poder têm a oportunidade de inverter o trem da história ao constituir um novo espaço na cidade, que além de público vira crítico. Esta ocupação, provinda inicialmente de necessidades pessoais e

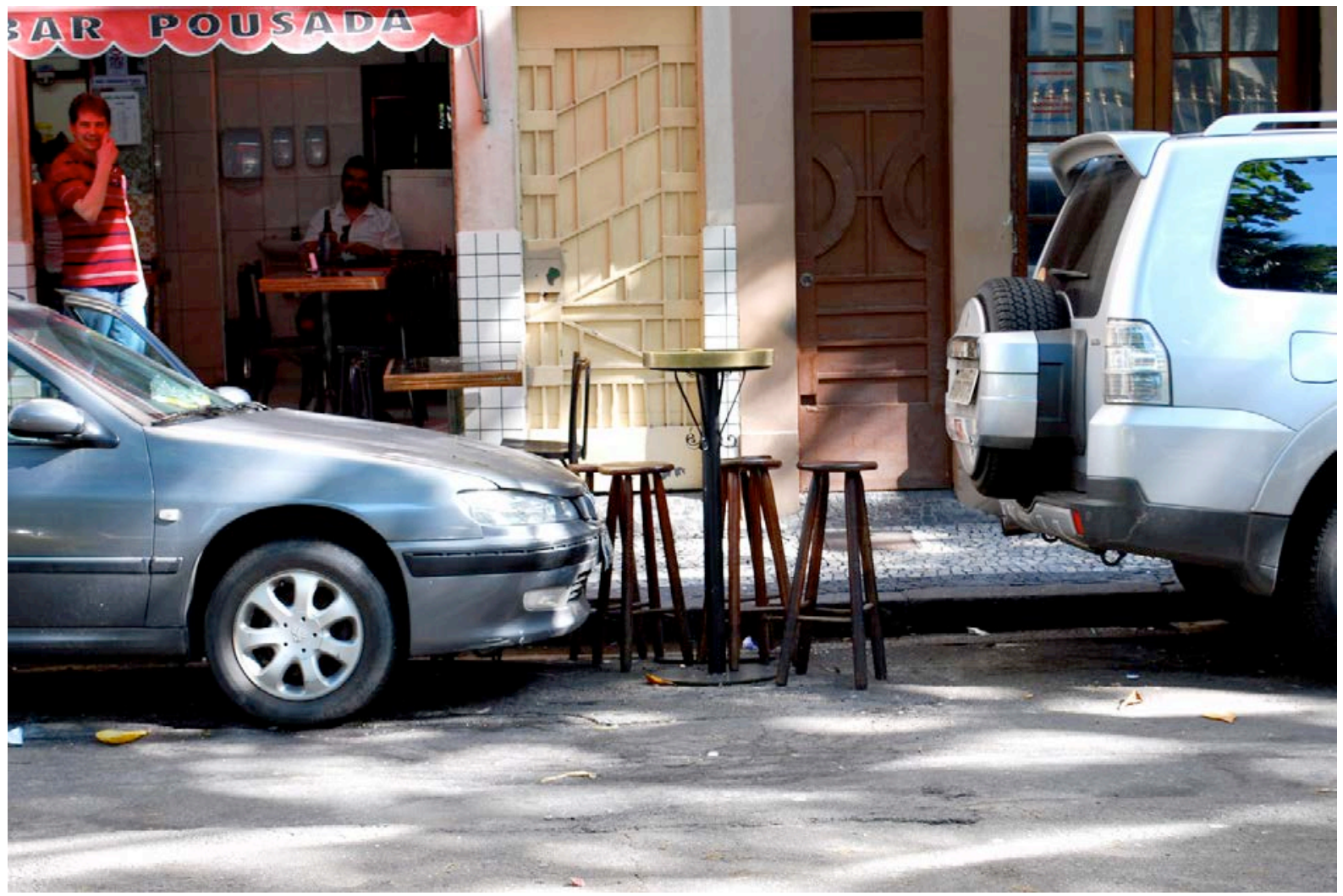

Ocupação informal em Copacabana

privadas, nunca é orientada num sentido consciente de tomada de poder. Quando a polícia detém controle de um espaço público é para simplesmente tomar o seu controle. Quando um camelô ocupa o mesmo espaço é pra vender o seu produto. Para Sassen, essa forma de ocupação ajuda construir uma nova forma de cidadania, expondo profundas falhas e erros de governos e sociedades.

O movimento dos “ocupas” foi provocado por veículos altamente especializados de comunicação, especialmente através das novas tecnologias de mídia social, desencadeado originalmente por uma revista especializada de cunho social politizado e subsequente mídia

${ }^{141} \mathrm{O}$ fenômeno dos rolezinhos é uma forma semelhante de clamar o espaço público, com a diferença que os limites físicos do shopping center designam de forma clara a natureza privada deste território enquanto que na praia estes limites são muito mais sutis. 
de radiodifusão. O movimento transformou-se rapidamente em um esforço coletivo de ativação de espaços públicos que possuíssem uma forte simbologia associada aos mercados

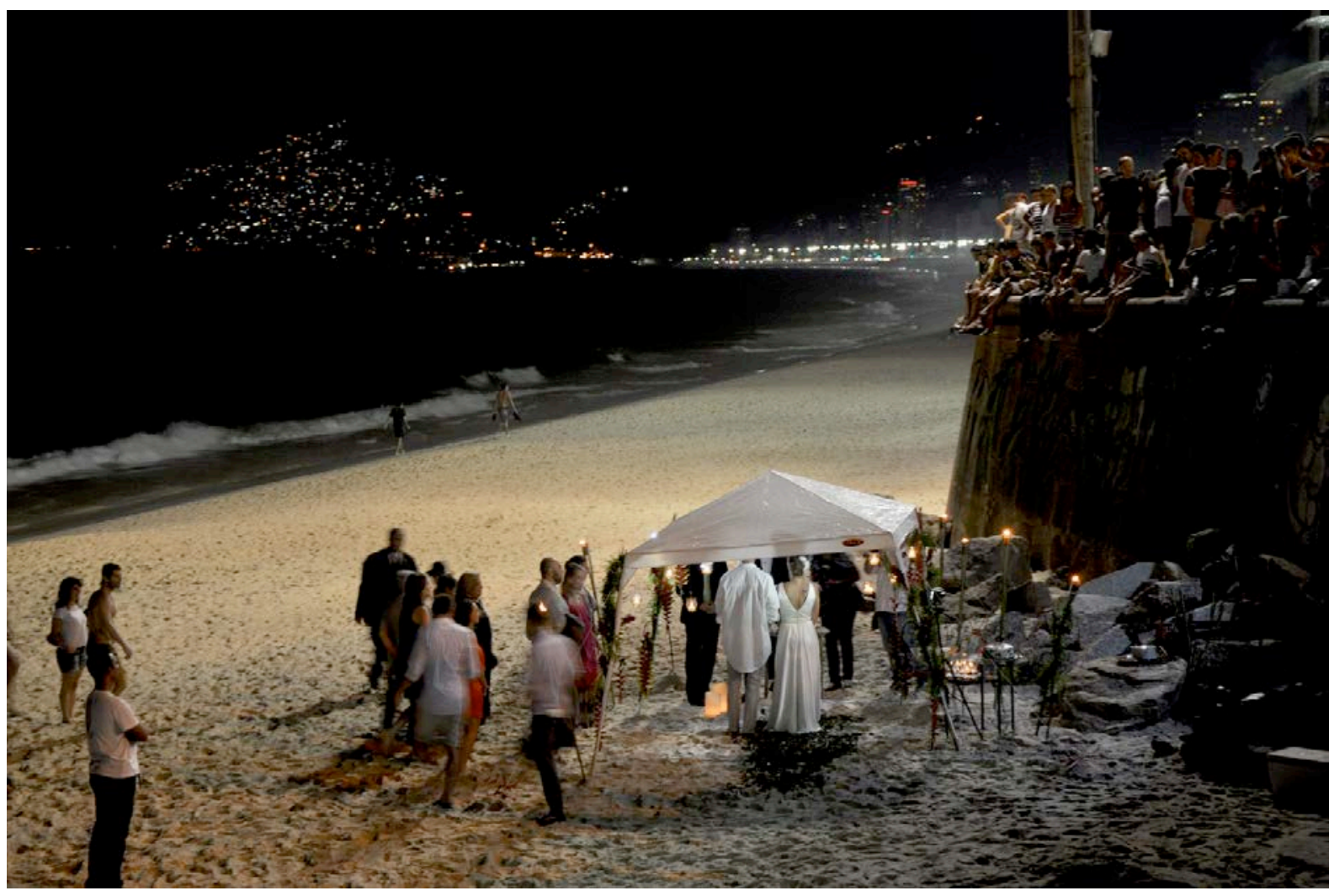

Ocupação informal no Arpoador

financeiros, principalmente nos grandes centros urbanos na América do Norte e na Europa, tornando-se sítios de demonstração pública. Iniciada no Parque Zuccotti de Wall Street em Nova York, o movimento dos "ocupas" apontou diretamente para as discrepâncias sociais causados por ações capitalistas beirando a prática criminosa. O movimento provocou manifestações políticas ao atravessar o seu mandato pela justiça social. O fato é que o movimento alterou radicalmente certos espaços públicos em grandes metrópoles acentuando seus significados e perguntando: que tem direito ao espaço público?

A ambiguidade do movimento dos "ocupas" é que o solo onde a ação toma lugar já é um espaço compartilhado, mesmo antes da reivindicação de “ocupá-lo". Pode ser que esses territórios específicos estivessem adormecidos no inconsciente coletivo, prontos para ganhar um novo significado através dos efeitos provocativos da agitação política. Todos estes territórios específicos de protesto devem ser considerados solos sagrados pela intrínseca história acumulada durante longos períodos de tempo, expressados pela habitação e luta de 
muitas gerações e consequentemente formado pelas conquistas e celebrações do lugar. $\mathrm{O}$ movimento sugere que pode não haver tal coisa como "espaço público", mas sim um "espaço compartilhado" ao longo do tempo, sobreposto pelas biografias acumulativas do lugar que dão forma ao espaço e às suas gentes, formadas a partir das experiências do passado, desconhecidas daquilo que há de vir e independentes das lutas coletivas que causaram as suas dissensões através da história.

A diferença entre o espaço urbano denso, superocupado do interior do bairro de Copacabana em contraste com a superfície tênue da praia é que no meio denso urbano encontramos mais referências simbólicas e evidências físicas quanto à sua história, à vigilância e à propriedade do que na praia. A superfície contínua da praia com o seu caráter suspenso carrega talvez a mesma bagagem simbólica que o meio urbano, mas o que ocorre é que estas simbologias manifestam-se de maneira efêmera, o que oferece o convite a outras formas de ocupação, fazendo do território da praia um espaço aberto de possibilidades, em constante transformação e em constante processo de definição própria. O resultado desse processo é que a informalidade e a improvisação verificada na praia - muito mais exacerbada do que no meio urbano pela falta de linhas de propriedade visíveis e controle territorial produzido pelo acúmulo de capital - criam uma infraestrutura efetiva para tipos de ocupação diversos. Então um mesmo pedaço da superfície da praia pode receber uma multidão de experiências: um concerto, um jogo de futebol, um ritual, um arrastão ou um beijo, formas mais livres das forças de vigilância e fiscalização dos meios urbanos densos e circunscritos.

Dadas tais circunstâncias, o verdadeiro desafio para o projeto urbano é entender que infraestruturas são tão importantes para a vitalidade e a experiência da metrópole contemporânea como a praça foi uma vez, como sugere Alex Wall. Infraestrutura aqui não é tratada como um elemento de engenharia associado às necessidades básicas como o suprimento de água, esgoto ou transporte, mas sim uma máquina urbana com a capacidade de servir os seus habitantes com o suporte adequado de que precisam para viverem na cidade, respondendo às suas necessidades básicas, mas também e principalmente investida nas relações sociais, emocionais e mitológicas com o seu território. A praia de Copacabana aqui é considerada como uma hiperinfraestrutura, pois serve ao seus cidadãos em múltiplas e diversas maneiras, através de formas pragmáticas de engajamento (trocas econômicas - as barraquinhas ou vendedores ambulantes) ou através do seu papel alegórico (o Réveillon, a 


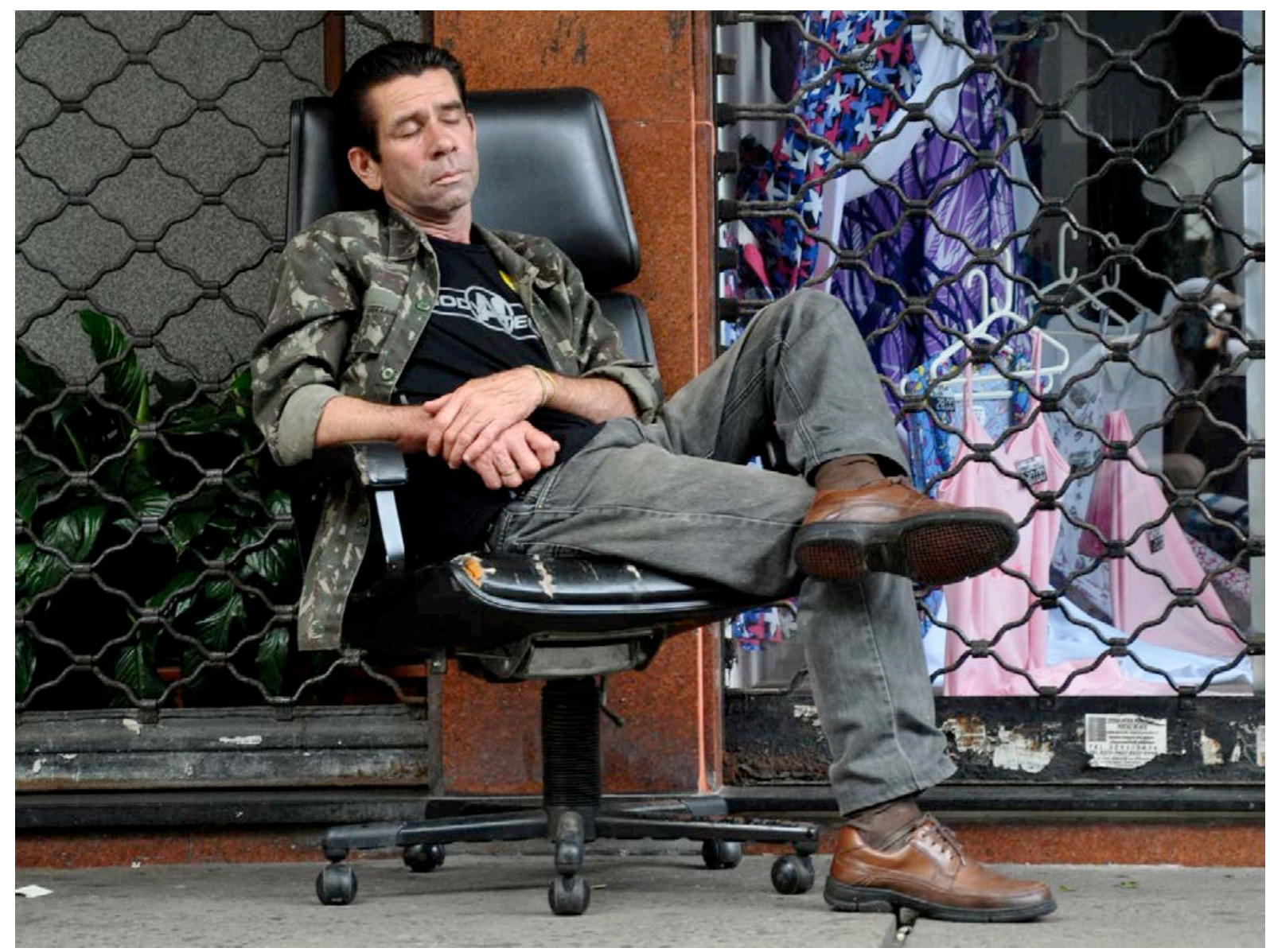

Espaço compartilhado em Copacabana

oferenda) respondendo assim às necessidades fundamentais de sustentação de uma cultura urbana carioca. Está assim criado um grande terreiro, pois além de oferecer as qualidades físicas para a sua ocupação permite que as suas atividades atinjam a escala significativa do mitológico. O que gera esta performance infraestrutural são os traços típicos da praia, comportando-se como um campo na sua configuração formal, o que admite o acidente, as mudanças e a improvisação: um território que acolhe a incerteza do real. ${ }^{142}$

Existe um outro tipo de movimento dos "ocupas" que acontece com uma maneira gradual e contínua no Brasil urbano. Tão logo abordamos espaços urbanos no Brasil, notamos profundos instintos culturais que informam a sua ocupação. O espaço público serve como uma infraestrutura para apoiar as ofertas de determinados serviços, como a venda de algo ou a oferta de serviço, como o conserto de uma panela ou de uma cadeira. Existe um certo respeito incontestável para o indivíduo que se utiliza do espaço público, e existe um entendimento

\footnotetext{
${ }^{142}$ Ver Stan Allen, "Field Conditions". Points and Lines: Diagrams and Projects for the City. New York: Princeton Architecture Press, 1999, pp. 90-103.
} 
mútuo da ação no espaço pelo coletivo. Deste modo, é evidente que a reivindicação de um espaço público serve para contrariar a regulação institucional da sua utilização. No Brasil, os governos municipais muitas vezes fecham os olhos para a aplicação da regulamentação, um tipo de acordo implícito, o que permite à informalidade predominar no espaço público. Outras vezes utiliza-se do violento aparato policial para imediatamente se livrar destas mesmas ocupações, pois compreendem o seu grau subversivo e crítico ao estado, na forma como alteram as normas capitalistas de troca.

A informalidade tem sido o modus operandi na cultura urbana brasileira como uma maneira de superar as necessidades humanas básicas que os governos são normalmente os responsáveis em fornecer: habitação, saúde e emprego. Diante da negligência, a informalidade define as táticas que seduzem as pessoas a assumirem o controle de sua própria vida, na tentativa de alcançar a tão almejada liberdade e independência na cidade. No Brasil urbano, todo mundo aceita com variáveis níveis de resistências a reivindicação simultânea de todos pelo espaço público. Há um entendimento subliminar que o espaço público não pertence a ninguém em particular, mas é um dom a todos. A maior contradição é que em uma cidade tomada pela pobreza como o Rio de Janeiro, onde altas densidades populacionais vivem largamente desprovidas das infraestruturas urbanas, a praia permanece aberta, respeitada e compartilhada, como os espaços sagrados de uma catedral, como o solo abençoado de um campo de futebol. Como ocorre em um campo de várzea, ninguém invade a praia. Podemos aqui questionar a precisão do termo "público" pois ele mesmo contradiz as maneiras, os comportamentos em que os espaços públicos são ocupados. Talvez uma definição mais precisa seria a noção de "espaço compartilhado", como Temporary Services sugere:

\footnotetext{
Usamos o termo "compartilhado" ao invés de "público" em relação a espaços nos quais as pessoas se encontram fora dos espaços domésticos. Isso nos ajuda a se concentrar, em estar no espaço com outras pessoas e colocar em primeiro plano a dimensão ética do fazer arte. Também evitamos reivindicar os utópicos, libertários espectros que são evocados quando as pessoas usam a palavra "público". Esses desejos estão lá e eles informam as nossas noções e desejos de democracia direta. No entanto, não existem verdadeiramente espaços "públicos" que sobraram, a menos que haja uma brecha nas funções normalizadas de tais espaços. ${ }^{143}$
}

\footnotetext{
${ }^{143}$ Eduardo Aquino, "Things in Trees: from private control to public space as shared social infrastructure (Public space / Occupied space / Shared space: A Conversation with Temporary Services)". In Chloé Womack e Brennan Broome (ed.), Doing Our Homework: Documents on Infrastructure and Collaboration in Social Practice. Windsor: Broken City Lab, 2012, p. 37.
} 
O sentido maior de "espaço compartilhado" na cultura urbana brasileira são as favelas, talvez o ápice da ocupação urbana no Brasil. Esta forma de ocupação agressiva de um território urbano não-reivindicado demonstra a tolerância entre as pessoas a partir da necessidade de ocupação espacial, e ao mesmo tempo serve como reconhecimento silencioso das impropriedades de urbanização dos processos colonizadores. Se no Brasil a história da ocupação dos espaços públicos revela a tragédia da colonização, ao mesmo tempo demonstra a engenhosidade do povo em recuperar criativamente um espaço que lhes foi tirado pelo abandono e indiferença. O equilíbrio entre informalidade e improvisação, juntamente com a capacidade de usar o espaço compartilhado como infraestrutura, expressa uma relação comum, agora compartilhada, produzindo um equilíbrio civil que ajuda a sustentar a vida urbana: alguns lucram com ela, alguns a consomem, alguns simplesmente ocupam, mas todos participam. Como artistas e designers praticando na esfera pública temos algo a aprender: considerar a produção de infraestruturas (micros, pequenas e grandes) para a interação das pessoas no espaço público, para assim gerar uma arquitetura e um espaço público como um todo, funcionando como uma entidade única: o interior está fora, e o exterior está dentro, produzindo bolsões indeterminados nos interstícios das estruturas urbanas que estariam disponíveis para serem ocupadas.

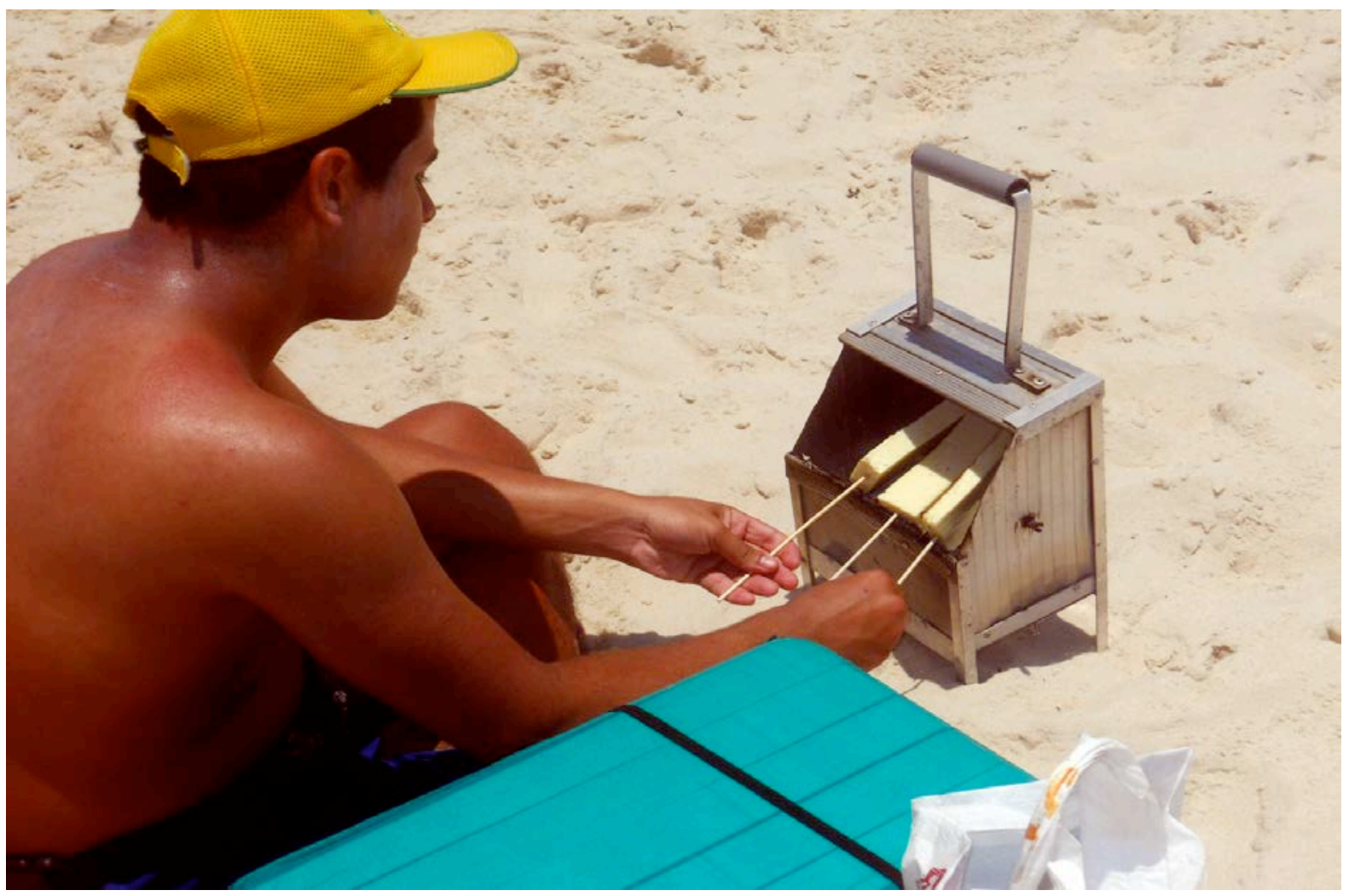

Espaço compartilhado na superfície da praia 
Já não existem mais cidades protegidas pelas contaminações internacionais das políticas e economias globalizantes. A confluência do capital produz paisagens urbanas genéricas que já não mais encontram afinidades com as culturais locais, mas sim desaparecem em uma mancha espacial dissolvente. A comodificação da arquitetura responde a essas tendências por meio de práticas que operam em escala global, ou escritórios locais produzindo uma arquitetura genérica que poderia ser situada em qualquer cidade do mundo. Ao mesmo tempo em que a vanguarda artística investe na significação do local, práticas alternativas de desenho urbano deveriam criticamente objetar a essas tendências generalizantes para recuperar uma agenda humanista para a arquitetura e para a cidade. Se por um lado a favela demonstra desequilíbrios enormes no balanço da estrutura urbana ela também representa a capacidade de expressão de um sentido local — a esperança da reconfiguração de uma identidade local pelo desenho da cidade. 


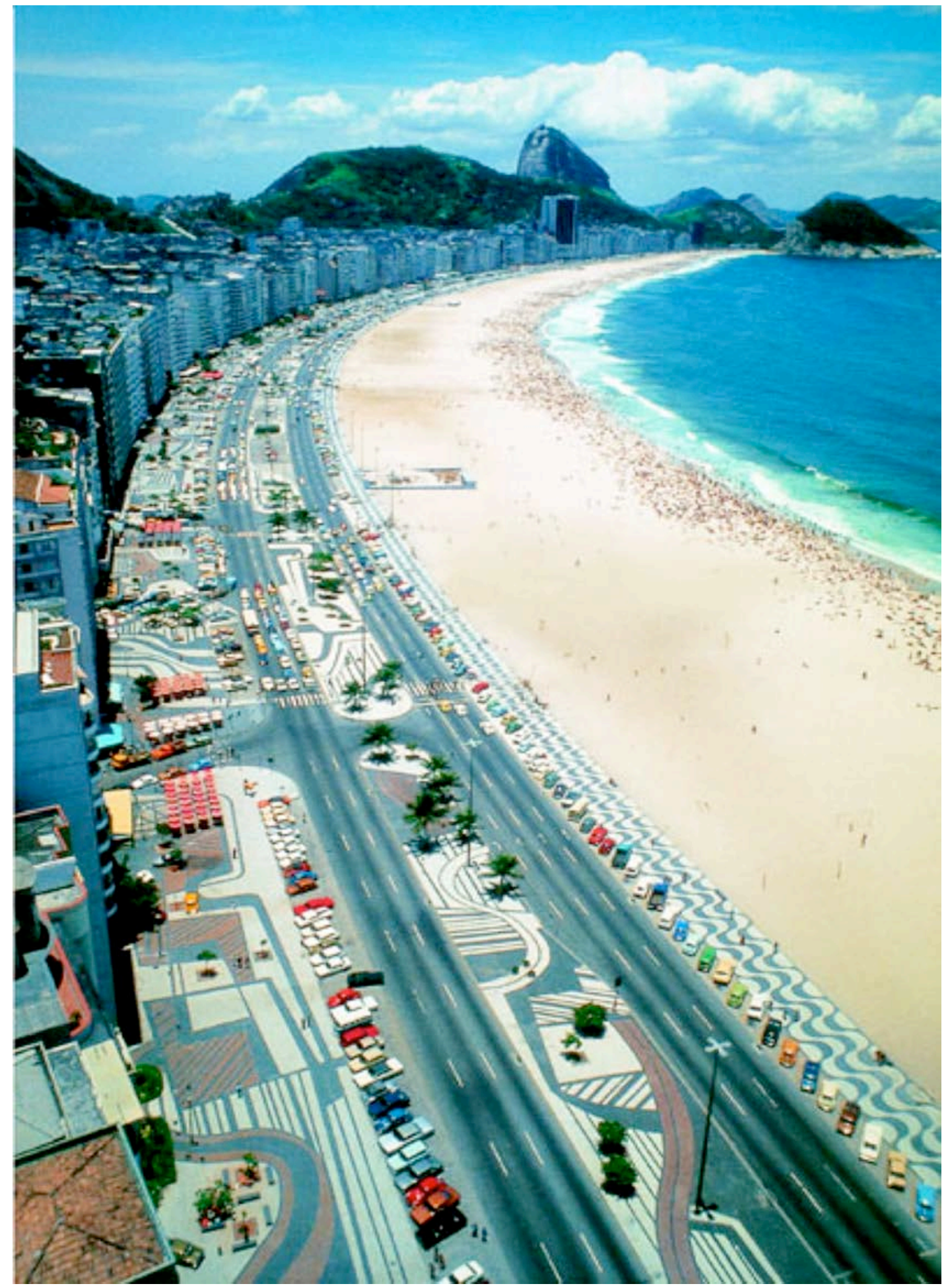

Copacabana de Roberto Burle Marx 


\title{
8_ ESPAC̣O-VIDA DA PRAIA: DE SUPERFÍCIE PARA A RELAC̣ÃO
}

\author{
I_Praia como cidade: Gesamtkunstoberfläche ${ }^{144}$
}

\begin{abstract}
Talvez a síntese das técnicas em paisagismo, arquitetura e urbanismo em uma forma híbrida destas práticas possa permitir a invenção de novos tecidos urbanos, flexíveis e maleáveis, de novas paisagens. Essa superfície dinâmica e estruturadora pode ser a única esperança de resistirmos aos excessos da cultura popular - a mobilidade inquieta, o consumo, a densidade, os resíduos, o espetáculo, e a informação -. absorvendo e redirecionando os episódios alternados de concentração e dispersão causados pelo movimento volátil de investimentos de energia e capital. ${ }^{145}$
\end{abstract}

O artista Robert Irwin, em um dos seus experimentos perceptivos no final dos anos 1960 e em colaboração com James Turrell, enclausurou-se por várias sessões numa câmara anecoica, que é um ambiente de medição científica de total privação sensorial onde sentidos como o olfato, a visão, a audição, o tato, o paladar são removidos num nível tão alto que provoca o corpo a um estado radical de escassez sensorial. O que ocorre é que, depois de longos períodos de privação, os sentidos ficam extremamente aguçados no reencontro com o ambiente exterior. Irwin descreve a sua experiência como exacerbada, como se a escala das coisas e suas qualidades sensoriais e perceptivas, como cores, luz ou sons, tivessem se tornado extremamente mais específicas e acentuadas - como se visse o mundo "pela primeira vez". Anos mais tarde, em uma cena do filme The Beauty of Questions, de Leonard Feinstein (1997), Irwin faz uma pausa de uma das suas instalações na Pace Gallery em Nova York e passa por uma experiência semelhante ao alcançar a rua depois de longas horas envolto pelo trabalho na galeria afirma: "Não importa quão longe se vai na criação de um trabalho, o mundo lá fora vai ser sempre mais bonito e mais rico do que tudo aquilo que a gente possa fazer em arte." Jorge Pardo evocou uma hipótese semelhante:

Aquela noção de interior e exterior está reformulando-se completamente. Isso acontece de forma muito contundente - você vai para uma galeria e depois de sair começa perceber que o lixo que está olhando no chão ou o carro que está entrando

\footnotetext{
144 “Superfície de arte total”, tradução nossa.

${ }^{145}$ Alex Wall, “Programing the Urban Surface”, James Corner (org.), Recovering Landscape: Essays in Contemporary Landscape Architecture. New York: Princeton Architectural Press, 1999, pp. 233-49, tradução nossa.
} 
são mais interessantes. Uma das razões de me interessar pelo funcional foi precisamente essa problemática. ${ }^{146}$

Se então olharmos o fenômeno da superfície no contexto específico da escultura poderíamos, como Irwin, Mondrian, Debord ou Pardo, sair de casa (ou do museu/galeria/ateliê) para rua e tentar decifrar o espaço exterior como formador também das percepções estéticas ligadas com a superfície da escultura. Um caminhar pela cidade, por exemplo, designa um traçado em uma superfície tão complexa quanto as relações de marcas de uma Mira Schendel ou uma Agnes Martin numa superfície de papel. A arte pública neste sentido traduz, mesmo que parcialmente, um campo entre o mundo institucional da arte e o mundo urbano dos espaços públicos, daí a tensão sempre presente em obras de arte no espaço público: um espaço contestado, discutido, controverso. Se esta possibilidade de transposição existe, entre arte e cidade, entre interior e exterior, ela nos oferece um laboratório de possibilidades para estabelecermos inter-relações entre a superfície da arte e a superfície da cidade, ambas superfícies de ação humana. ${ }^{147}$ A superfície da cidade é marcada pelas mais diversas camadas que constituem a organização de objetos urbanos, visíveis e invisíveis, como edifícios, ruas, sistemas, infraestruturas, psicogeografias, e das várias negociações sóciopolíticas. Mas a cidade então poderia então ser, analogamente, comparada às camadas que constroem uma imagem sobre a tela, ou às dobras, incisões, agrupamentos, remoções, sobreposições, tratamentos, reações químicas e o toque, ações que verificamos nos procedimentos em escultura.

Poderíamos então eleger qualquer superfície urbana para levantar esta hipótese paralela da aproximação escultura e cidade? Não seriam as obras específicas que elegemos aqui representantes de uma trajetória provável da evolução desta questão? A própria história da arte, pela sua impropriedade ou limitação, ou o nosso próprio rumo precário pelas "histórias da arte" identifica certas obras como significativas para a questão da superfície em escultura. A Família Boyle, por exemplo, engajou a superfície de ruas e calçadas do mundo urbano para a formatação dos seus painéis, ou também Francis Alÿs, que elegeu calçadas e

\footnotetext{
${ }^{146}$ Press release de uma exposição na Galeria Gagosian. Disponível em: <http://www.gagosian.com/exhibitions/2010-07-16_jorge-pardo>. Acesso em: 5 de julho de 2010, tradução nossa.

${ }^{147}$ Seria bacana imaginar uma história, um conto ou romance a respeito de um pedaço diminuto de alguma calçada urbana, por um tempo estendido, e ao mesmo tempo imaginar as marcas em um pedaço de papel dos seus movimentos por uma cidade, como num desenho situacionista.
} 
ruas através do mundo como suporte e material para suas ações. Aqui, então, quando consideramos o espaço da cidade, passamos de uma triagem aleatória para investirmos em um tipo de superfície urbana onde a problemática da superfície se evidencia primeiro na sua direta aparência, mas também nas suas entranhas e invisibilidades, no seu coeficiente de complexidade elevado, e no seu aspecto pluricultural. A nossa experiência e observação nos levou à praia de Copacabana, convidando-nos a um outro olhar.

Por Copacabana ser um dos espaços públicos mais bem-sucedidos que conhecemos, e uma das superfícies urbanas mais complexas que podemos identificar, ela resulta em elementos em transição contínua devido às suas qualidades temporais, características essas incompletas na maioria de qualquer outro espaço público. Copacabana nos provoca como uma escultura minimalista: uma simplicidade formal produzindo oportunidades de variadas experiências e diferentes formas de habitação em uma dialética entre a sua superfície e o espaço envolvente, o equivalente à superfície de uma obra de arte minimalista. A celebridade de Copacabana poderia indicar um certo imediatismo trivial por se mostrar como exemplo aparentemente óbvio. Mas da mesma maneira que os relevos de Athos Bulcão marcaram profunda e intuitivamente o momento da modernidade através de Brasília, a superfície da praia de Copacabana se apresenta como um momento ímpar na definição da percepção carioca. Como a sensação de Irwin saindo da câmara anecoica e experimentando o mundo pela primeira vez e de maneira nova, Copacabana vem ao nosso encontro para sempre surpreender e aguçar as percepções, nem tanto pela sua forma mas pelo poder de construção do lugar, característica da modernidade brasileira.

Para estabelecer estas novas relações, não somente entre superfície e a obra de arte, mas entre arte e arquitetura, e até mesmo entre arte e cidade, entre a superfície da arte e a superfície da cidade, poderíamos considerar Copacabana como um modelo de "obra de arte total", como foram considerados Gesamtkunstwerks a catedral gótica, o trabalho comunitário da Idade Média, ou até mesmo a ópera, conforme Richard Wagner. ${ }^{148}$ Agora desinstitucionalizada pelo seu apelo e influência popular ${ }^{149}$, pela sua ocupação orgânica e temporal, pelo seu impacto no imaginário de um povo, que é formada não só pelas ondas

\footnotetext{
${ }^{148}$ Ver "A síntese das artes e a moderna Arquitetura brasileira dos anos 1950", de Fernanda Fernandes. Disponível em:

$<$ http://www.iar.unicamp.br/dap/vanguarda/artigos_pdf/fernanda_fernandes.pdf >. Acesso em: 20 de junho de 2010.

${ }^{149}$ Ariano Suassuna diria que, na formação da experiência brasileira, qualquer expressão que se preze tem que necessariamente passar pelo popular.
} 
originais das suas calçadas, ou pelo desenho biomórfico de Burle Marx, ou pelas suas areias que recebem suas tribos de múltiplas raízes, Copacabana é aqui considerada uma "superfície de arte total", uma Gesamtkunstoberfläche.

A taxonomia crítica da superfície a partir da escultura sugere que esta evolução não seja linear nem disciplinar. Imaginamos re-significações a partir de referências além do campo da escultura, abrindo questão para relações com a arquitetura e o espaço urbano. Os exemplos escolhidos, longe de serem os únicos representantes expressivos para esboçar a questão, são discricionários de uma estratégia onde estas manifestações espaciais se concernem à questão da superfície. Parafraseando Irwin, uma superfície tão complexa como Copacabana pode "ser sempre mais bonita, mais rica do que tudo aquilo que a gente possa imaginar em arte”. A grande diferença aqui são os atores, que ativam a superfície em todo o tempo tornando-a viva. Temos na superfície da praia a participação massiva de gentes de todos territórios convivendo ali, num mesmo espaço, em uma experiência que supere qualquer experiência de contemplação de um objeto de arte controlado pelo espaço da galeria.

A partir das dinâmicas dadas na superfície da praia, essas novas relações estéticas e sociais são agora aglutinadas à existência de um corpo público, em estado de fluxo constante. Como Hélio Oiticica, que se serviu tão significativamente da favela e do morro como referências fenomenológicas pessoais para sua intrigante pesquisa, descemos do morro convidando um outro olhar sobre Copacabana, para agora ser essa a nossa referência principal no rumo à compreensão da natureza da superfície em relação à arte, à arquitetura e às complexas dinâmicas do espaço público urbano, agora vistas a partir do espaço-vida da praia, destinando-se à praiapaisagem.

\section{II_A superfície da cidade}

Para aqueles que confrontam a questão da cidade contemporânea, a superfície urbana seria talvez um dos primeiros elementos identificados, pois é a partir da superfície que a cidade acontece: no momento inicial da fundação de todas cidades "toca-se a sua superfície". O que seria então a superfície urbana? Quais seriam as relações entre este termo - superfície —, carregado de significados e usos, e o desenho da cidade? Quais seriam as relações entre a superfície urbana e os sistemas, as infraestruturas, as arquiteturas e os espaços da cidade? Poderíamos identificar uma arquitetura gerada pela condição de superfície e estudá-la como 
uma tipologia específica, uma arquitetura impregnada de urbanismo, um urbanismo estruturado pela arquitetura, um desenho não só dos objetos urbanos mas dos “entres", das relações entre todas as partes que constituem a cidade?

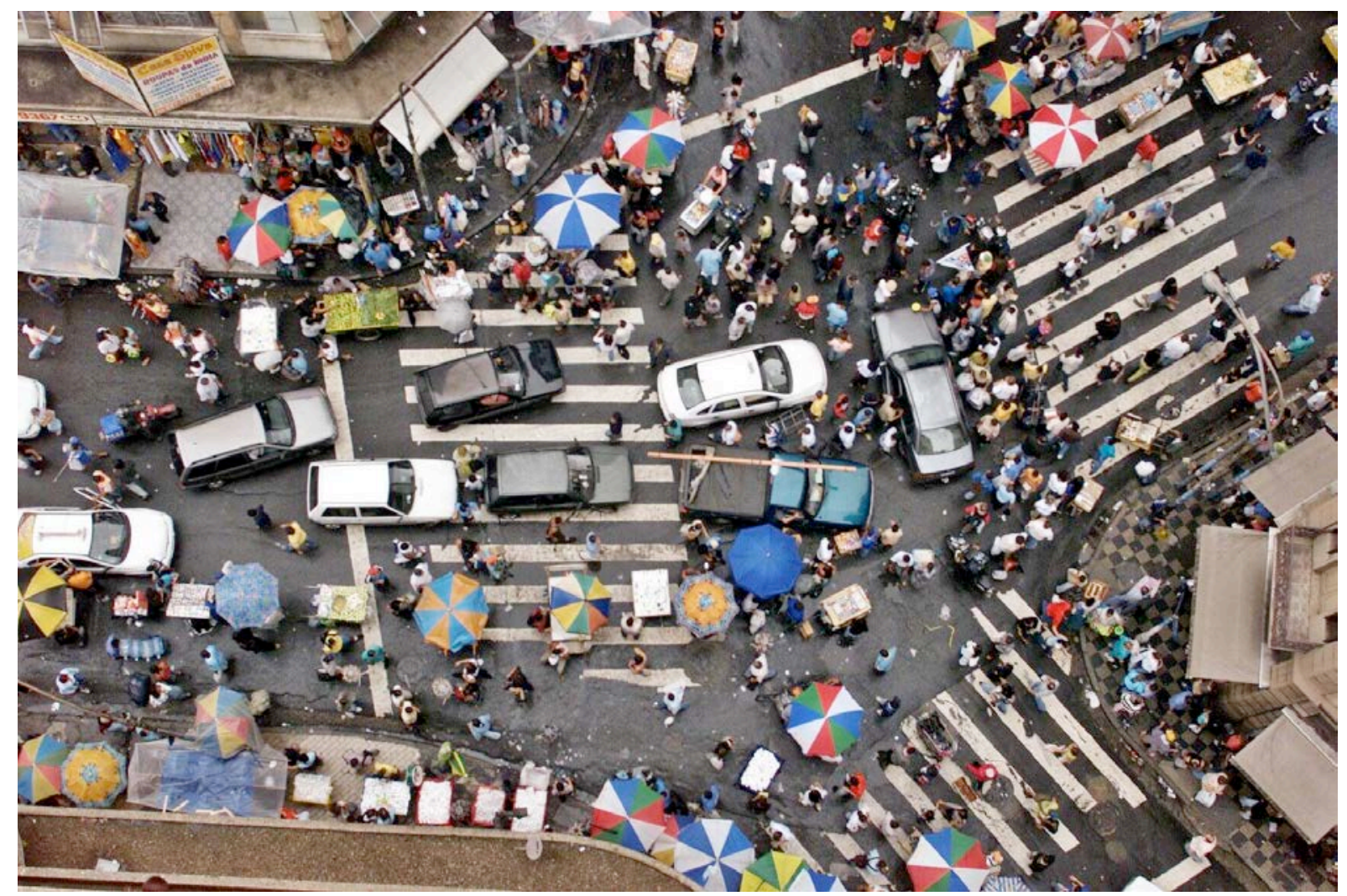

A superfície da cidade: Esquina da Rua 25 de Março e Ladeira Porto Geral (São Paulo)

Dentro do conjunto de representações convencionais as quais arquitetos, urbanistas, geógrafos, engenheiros, planejadores e outros profissionais que trabalham com a cidade utilizam para analisar e propor soluções urbanísticas estão as clássicas plantas, planos, gráficos, mapas, diagramas, elementos de retenção de informação e de interpretação lógica, todos estes intrinsecamente caracterizados pela sua forma bidimensional. Se por um lado ficam evidentes as limitações de tais instrumentos de representação, considerando-se a complexidade, as dinâmicas, as evoluções político-culturais, a não-linearidade das cidades e as suas dimensões verticais, em elevação, as suas condições subterrâneas, por outro lado é claro que esta bidimensionalidade sugere a predominância de uma extensão, uma expansão, a 
ampliação de um campo, um tablado urbano virtualmente indeterminado, o desenvolvimento de uma superfície totalizadora na qual toda cidade acontece. ${ }^{150}$

A arquitetura da cidade passa inevitavelmente pelo aval do capitalismo de consumo, que valoriza a imagem da cidade e o objeto da arquitetura, traduzindo-os em objetos de desejo. Tal influência aprisiona uma consciência sem critérios adequados, frequentemente automatizada pelos processos tecnocráticos das escolas de engenharia e arquitetura chegando até às práticas, levando os profissionais urbanos a concentrarem-se no problema do objeto isolado, técnico ou tectônico, ou na exclusiva imagem de representação, desvencilhando-se assim das múltiplas potencialidades de utilização da arquitetura como instrumento efetivo na construção das nossas cidades e das redes que formam as relações entre os objetos urbanos.

Existe uma necessidade de olhar a arquitetura de maneira mais abrangente, para além dos limites do edifício, ao considerarmos como essencial na abordagem do projeto este encontro fundamental entre o objeto e o solo. ${ }^{151}$ Não se trata aqui de nos limitarmos à questão desta linha restrita e determinante, mas sim compreendê-la na sua forma relacional, isto é, não é a linha visual do encontro do objeto com a superfície urbana em si, mas sim o fenômeno que ocorre entre o interior e o exterior do edifício, o que ocorre na sua extensão para fora e para dentro, sem limitar-se ao seu invólucro somente, mas abrangendo sua dilatação e interpenetração com a cidade. Se sintetizarmos estas relações em uma entidade única, agora com um foco no desenvolvimento do desenho da cidade, teríamos de observar essa extensão nas suas mais variadas formas de abordagem, não mais confinadas pela própria bidimensionalidade da planta, mas atentando-se também à sua expressão seccional, em corte e elevação.

Nesta extensão que articula as relações entre o edifício e a cidade, a superfície urbana indica três elementos que estabelecem uma base crítica de ação (desenho), contribuindo assim à constituição dos parâmetros de projeto para a cidade existente: 1] superfície contínua entre exterior e interior; 2] a superfície como infraestrutura; 3] o urbanismo de superfície. Está dado o desafio ao projeto para contribuir diretamente na construção das dinâmicas da cidade e

\footnotetext{
${ }^{150}$ O Google Earth homogeneíza todas as cidades que agora podem ser representadas através da bidimensionalidade da tela do computador, uniformizando todos os desenhos urbanos em uma única superfície de representação.

151 Para a questão do encontro do solo com a arquitetura veja Ilka Ruby e Andreas Ruby, Groundscapes: El reencuentro com el suelo em la arquitectura contemporânea. Barcelona: Gustavo Gili, 2006.
} 
convidá-lo a livrar-se da vocação tradicional de isolamento. A partir desta matriz operacional, a intenção é observar e tatear uma leitura crítica de alguns projetos onde a superfície aparece como protagonista na estruturação de relações espaciais. Nota-se que nos últimos anos as discussões teóricas em torno do conceito de superfície em relação à arquitetura se deteve exclusivamente no seu invólucro, motivada especialmente pelos novos materiais e pelas novas tecnologias digitais de produção. Vários trabalhos significativos foram publicados nos quais destaco aqui Surface Architecture, de David Leatherbarrow e Mohsen Mostafavi (2002), e Surface Consciousness, de Mark Taylor (2003). É importante distinguir que a abordagem do conceito superfície neste texto não se refere aos atributos tectônicos da arquitetura, centrados predominantemente na superfície material e horizontal das fachadas, mas sim a aspectos relacionais entre o edifício e a cidade, concentrando-se assim no fenômeno do campo ampliado, isto é, uma discussão da superfície horizontal que organiza e estrutura o tecido urbano.

III_Reprodução de poeira: total disponibilidade do solo urbano

Na desconstrução da superfície como objeto urbano retornamos à sua epistemologia a partir de alguns procedimentos artísticos. Em 1920, o fotógrafo e pintor americano Man Ray (18901976), membro da cena dadá de Nova York e um dos amigos próximos de Marcel Duchamp (1887-1968), produziu uma fotografia intitulada Dust Breeding (Reprodução de poeira), que era simplesmente uma imagem fotográfica da obra The Bride Stripped Bare by Her Bachelors Even (A noiva despida por seus celibatários, mesmo, 1915-1923) ou The Large Glass (O Grande Vidro) de Duchamp. A imagem foi criada após a referida obra ter acumulado uma quantidade considerável de poeira depois de um ano de armazenamento. A fotografia foi tirada de uma posição superior, com uma exposição de duas horas de duração que capta muito bem a delicadeza da complexa textura e a diversidade dos materiais assentados sobre a superfície do vidro. Dust Breeding foi uma colaboração entre Man Ray e Marcel Duchamp que marca uma fase crucial no desenvolvimento da obra de Duchamp. Depois que a fotografia foi tirada, Duchamp limpou O Grande Vidro quase totalmente, deixando uma parte dos cones cobertos de poeira, que permanentemente afixou na placa de vidro com verniz diluído. 


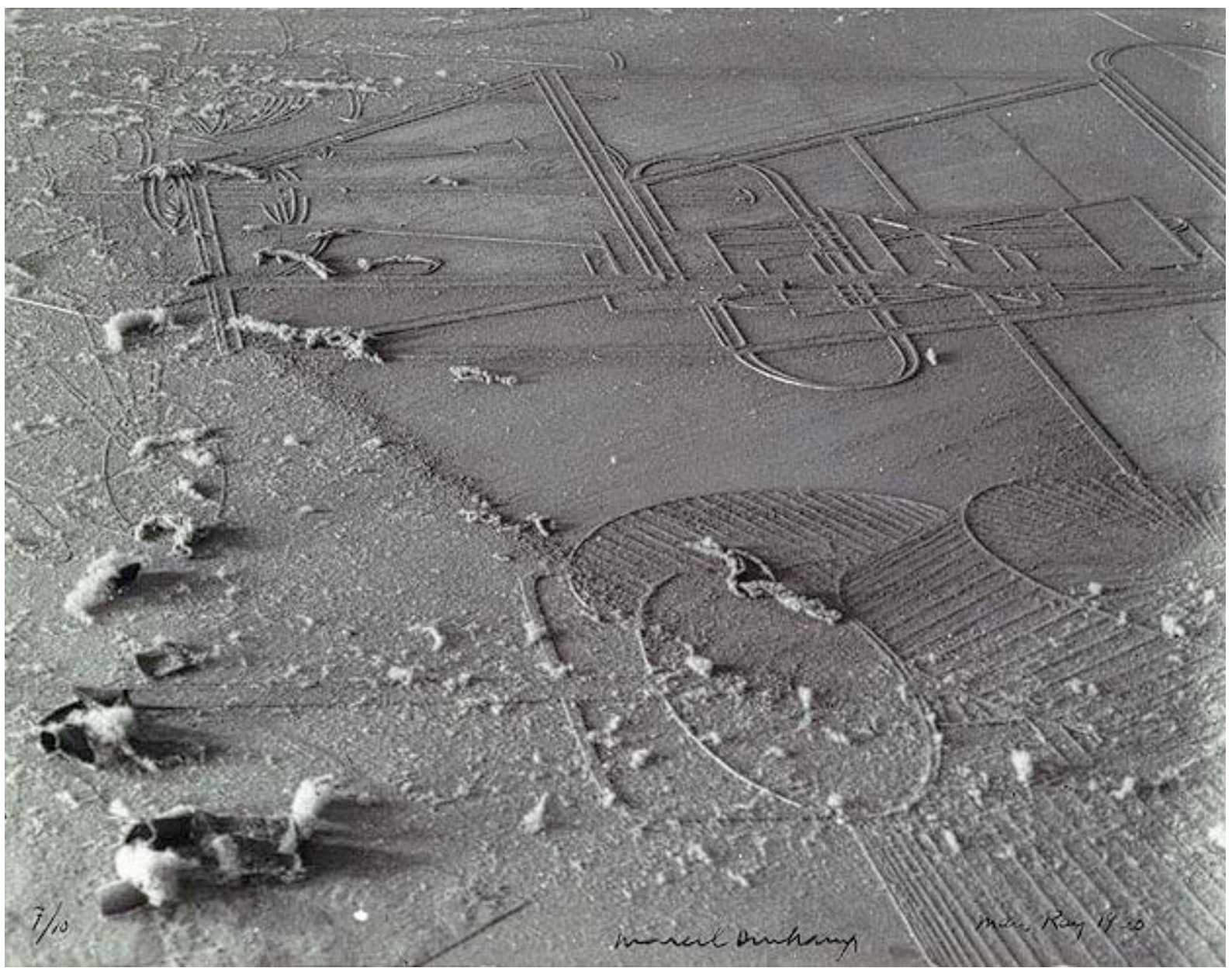

Marcel Duchamp e Man Ray, Dust Breeding (1921)

Na edição de outubro de 1922 do Littérature, o primeiro jornal surrealista, editado pelo poeta e polemista André Breton, Dust Breeding apareceu acompanhada por um texto tão misterioso quanto a imagem. Abaixo da fotografia um texto poético dizia o seguinte: "Voici le domaine de Rrose Sélavy / Comme il est aride - Comme il est fértil - Comme il est joyeux Comme il est triste!” (Eis a terra de Rrose Sélavy / Como é árida / Como é fértil / Como é alegre / Como é triste!) Conclui-se com o seguinte crédito: "Vue prise en aeroplane / Par Man Ray 1921.” (Imagens tiradas de avião por Man Ray em 1921). A fotografia, evidentemente não tirada de um avião, é uma reminiscência de uma paisagem desértica vista de cima, o que parece ser uma cadeia de dunas que se estendem do centro do primeiro plano para o horizonte. Mais longe, uma rede de linhas assemelha-se como os antigos geoglifos do deserto de Nazca, ou as pistas de um moderno aeroporto atravessando a sua superfície. ${ }^{152}$

\footnotetext{
152 Jonathan R. Fardy. Double Vision: Reviewing Man Ray and Marcel Duchamp's 1920 Photo-Text ltese de mestrado). Faculty of Arts, Bowling Green State University. Bowling Green, OH: 2008, p. 1.
} 
O Grande Vidro se trata de uma das obras de arte mais complexas do século 20, e mesmo com um livro especialmente escrito pelo próprio Duchamp para acompanhá-la (The Green Book / O Livro Verde), perdura como uma das mais enigmáticas obras da história da arte. Gostaria de entreter aqui estas duas obras enquanto urbanismo. Tanto O Grande Vidro quanto o Dust Breeding carregam um enorme impacto pela vivacidade e mistério visual que apresentam. No caso de Dust Breeding, o acúmulo de poeira nos remete a uma modificação do senso preciso da escala do objeto, transformando o objeto em uma paisagem imaginária. Observamos agora esta nova paisagem, tão misteriosa e intrigante quanto a obra original a qual se refere.

Essa dualidade entre objeto e paisagem é presente em Dust Breeding. Reconhecemos o objeto, mas ao mesmo tempo que ele nos remete a um outro mundo, um mundo prépaisagem-urbano, um mundo de fantasia, mas precisamente estruturado dentro de uma subjetividade própria, com uma sugestão eloquente de lugar. Vou mais adiante: uma representação duplamente plana, O Grande Vidro e Dust Breeding, duas obras predominantemente bidimensionais, coexistindo em uma única, dois autores se somando em um, produzindo um elogio poético à superfície, tornando uma superfície aparentemente abandonada e sem sentido ${ }^{153}$ em um complexo sistema de relações revelando uma sequência de camadas, cada qual habitada por significações, que por mais que específicas que sejam dentro da estrutura do objeto, são abertas no sentido das suas intencionalidades. Dust Breeding apresenta-se tal como a superfície urbana, que na sua aparência esconde as profundas complexidades da sua história e constituição.

Podemos então sintetizar que, como uma tela vazia que espera pelo seu pintor, as cidades se formam pela composição gradual de um lugar, a criação progressiva de uma interminável série de relações entre os seres e o lugar, que escolheram assim viver em agrupamentos, em uma determinada geografia, compondo neste processo uma "imagem" das relações entre esta gente e o seu espaço eleito. A "tela" neste caso seria a superfície na qual o urbano evolui. Como o próprio significado morfológico sugere, superfície tem de ser considerada para além da sua pura aparência, pois não é simplesmente uma "imagem" da cidade, mas, pelo contrário, é exatamente nesta superfície que as relações fundamentais se passam, onde a estruturação da vida urbana se dá. A imagem ícone do primeiro traço de

\footnotetext{
${ }^{153}$ Temporariamente, obra de arte, quando armazenada, perde o seu sentido primordial, que é ser partilhada com uma audiência, um aspecto do trabalho de Duchamp fundamental: a participação do observador completando a obra.
} 
Brasília, tanto no papel como no próprio solo, é a cruz que indica, geometricamente, a equação sintética da própria definição de superfície, uma linha em movimento, que no desenho de Lúcio Costa é sugerida pelo deslocamento do seu próprio eixo, o primeiro gesto antevendo uma total disponibilidade do solo urbano dentro de uma organização precisa.

\title{
IV_ Gramática de superfície I Gramática profunda
}

Num primeiro momento compreendemos que as cidades se estabelecem sobre a superfície de uma paisagem, de um lugar. Teríamos que suspender então a plena aceitação desta superfície como um plano neutro, onde simplesmente se "posam" objetos urbanos. A superfície urbana não é um plano puro e simplesmente, nem podemos declará-la como homogênea ou uniforme. Em Dust Breeding, a superfície na poeira associa-se com a superfície do Grande Vidro e por conseguinte com as suas significações, gerando um sistema de relações revelado na sequência de camadas. A estratificação total é o que constitui a superfície. Como na indagação de Ludwig Wittgenstein em relação ao significado das palavras, tal é a superfície urbana dentro das suas intrínsecas complexidades:

\begin{abstract}
No uso das palavras pode-se distinguir "gramática de superfície" de "gramática profunda". O que imediatamente impressiona sobre o uso das palavras é o caminho que são utilizadas na construção da frase, parte do seu uso, e que poderíamos dizer, como podem ser absorvidas pelo ouvido. E agora compare à gramática profunda, digamos a explicação da palavra "significar", com o que a gramática de superfície nos leva a suspeitar. Não me surpreendo como achamos difícil desvendar as nossas maneiras de conhecer. ${ }^{154}$
\end{abstract}

Para Wittgenstein, os significados das palavras mudam segundo o contexto em que são usadas. Quando falamos uma palavra dentro de uma conversa, o mesma palavra pode assumir significados díspares se a olhamos fora do mesmo contexto, por exemplo, da sua significação no dicionário. O significado do dicionário produz uma qualidade abstrata das palavras.

Wittgenstein chamou esta expressão isolada do dicionário, mais imediatista e imparcial, de "gramática de superfície”, enquanto a segunda abordagem, mais espontânea, contextualizada, incorporada a significados particulares, pausada, comedida e crítica, engajada em um processo de comunicação, de "gramática de profundidade".

\footnotetext{
${ }^{154}$ Ludwig Wittgenstein. Philosophical Investigations. New York: MacMillan, 1953, p.168, tradução nossa.
} 
Podemos assim traçar um paralelo entre a superfície urbana na sua apresentação mais aparente, tipicamente visual e abstrata, daquilo que vemos e acompanhamos na cidade em um primeiro momento cotidiano de "gramática de superfície urbana", e as potencialidades da superfície como elemento estruturador do espaço, como um campo de relações intricadas, existindo dentro de camadas físicas mas também fenomenológicas, onde as relações humanas com o espaço se dão através de diferentes estratificações perceptivas e processos culturais, indicando assim uma "gramática profunda urbana". Este paralelo com Wittgenstein propõe uma definição da superfície urbana que não se detém nas definições elementares de superfície (solo, pavimento, piso, etc.), mas que apreende os seus significados, entendendo esta superfície como uma “espessura complexa”.

Distinguimos assim o termo "superfície" do seu significado elementar, como simples plano estendido, para a direção que gostaríamos de focar aqui, isto é, da vocação da superfície como um plano organizador, estruturador das complexas relações urbanas. O que já está embutido no significado de superfície é uma condição espacial íntegra ao seu caráter plano: toda superfície tem um sobre e um sob. A superfície urbana assume este caráter de profundidade, a evidência de que não é na verdade uma simples membrana, mas que é exatamente na sua espessura que se dão as dinâmicas urbanas.

Um dos exemplos mais singulares desta significação são os dois gestos fundadores de Lúcio Costa por ocasião da criação de Brasília. O primeiro seria quando fez o gesto da cruz para determinar, no projeto para o concurso, os eixos monumental e o das quadras. Este simples gesto, tão simbolicamente ligado ao imaginário brasileiro através da própria figura da cruz, mas também pelo desejo de novas conquistas - o desenho da cruz num papel em branco - em si só determina uma definição de superfície, ou seja, um plano construído a partir de duas linhas, uma região que pode ser planificada.

Poderíamos, para emprestar o método de Wittgenstein, considerar este primeiro gesto da cruz de Costa como uma forma de "gramática de superfície", pela sua espontânea abstração e inteligência intuitiva. O segundo gesto foi a localização da Rodoviária na interseção das duas linhas, entre os dois eixos. Existe aqui uma compreensão operacional mais consequente: que o Plano Piloto de Brasília, não é, de fato, uma simples superfície contínua, como a imagem de uma nova cidade no planalto poderia sugerir, mas sim um plano que se desenvolve em 
relações estratificadas complexas. ${ }^{155}$ É exatamente no espaço de encontro entre os dois eixos que a Rodoviária foi posicionada, facilitando a sua articulação com o sistema viário, mas também relacionando a arquitetura com o simbólico-imaginário: o núcleo da cruz é o centro da cidade, e é aí que todos chegam e partem, é daqui que alcançam todos os pontos da cidade - experiências formadoras de uma identidade urbana cultural.

Mais do que um edifício a Rodoviária de Brasília é um lugar. A percepção de se aproximar de uma arquitetura é substituída por esta experiência de chegar, sair, de estar na cidade, mais do que entrar e sair de um prédio por uma porta. Na sua despretensiosa presença a Rodoviária de Brasília representa uma contribuição incontestável para compreendermos a superfície urbana e suas camadas contíguas como elemento organizador, e não como objeto isolado da cidade - uma arquitetura impregnada de urbanismo e um urbanismo estruturado pela arquitetura, não um objeto pousado no solo urbano como uma escultura numa base, mas um desenho dos "entres", das relações entre todas as partes que formam a cidade naquele momento. Desaparecida como objeto e articulada como linguagem urbana a Rodoviária de Brasília seria um bom exemplo da "gramática profunda" de Wittgenstein.

Não só de profundidade sobrevive a gramática urbana. A superfície urbana na sua continuidade apresenta-se sucessiva, sem obstáculos, e como Gilles Deleuze e Felix Guattari sugerem, é dentro desta continuidade que surgem os vincos, pregas, rugas e dobras. São nestes momentos particulares que a superfície se transforma para além da planura. Comparando a dobra deleuziana com a condição urbana, diríamos que qualquer evento causa uma dobra: um cruzamento, um encontro, um desvio, uma mudança abrupta na elevação (a ladeira ou a guia da calçada), um sinal fechado, uma árvore caída, um barulho ensurdecedor, um silêncio, inesperado ou não. As dobras evidenciam a realidade da cidade na negação de uma brandura falsa na continuidade da superfície urbana. Até um simples caminhar se constitui em uma sequência de dobras-eventos: a mudança da textura do piso, um olhar desconhecido, uma brisa repentina, um pensamento abrupto, o quente do sol, a luz da noite. A dobra dialoga com o rizoma. O rizoma como ordem "desordena” pois na tentativa de conciliação das camadas se multiplica fora da lógica sequencial almejada:

\footnotetext{
${ }^{155}$ Haja vista o sistema viário como instrumento estruturador da cidade, que depende exatamente das relações de profundidade da topografia (décalage) para negociar as suas circulações.
} 


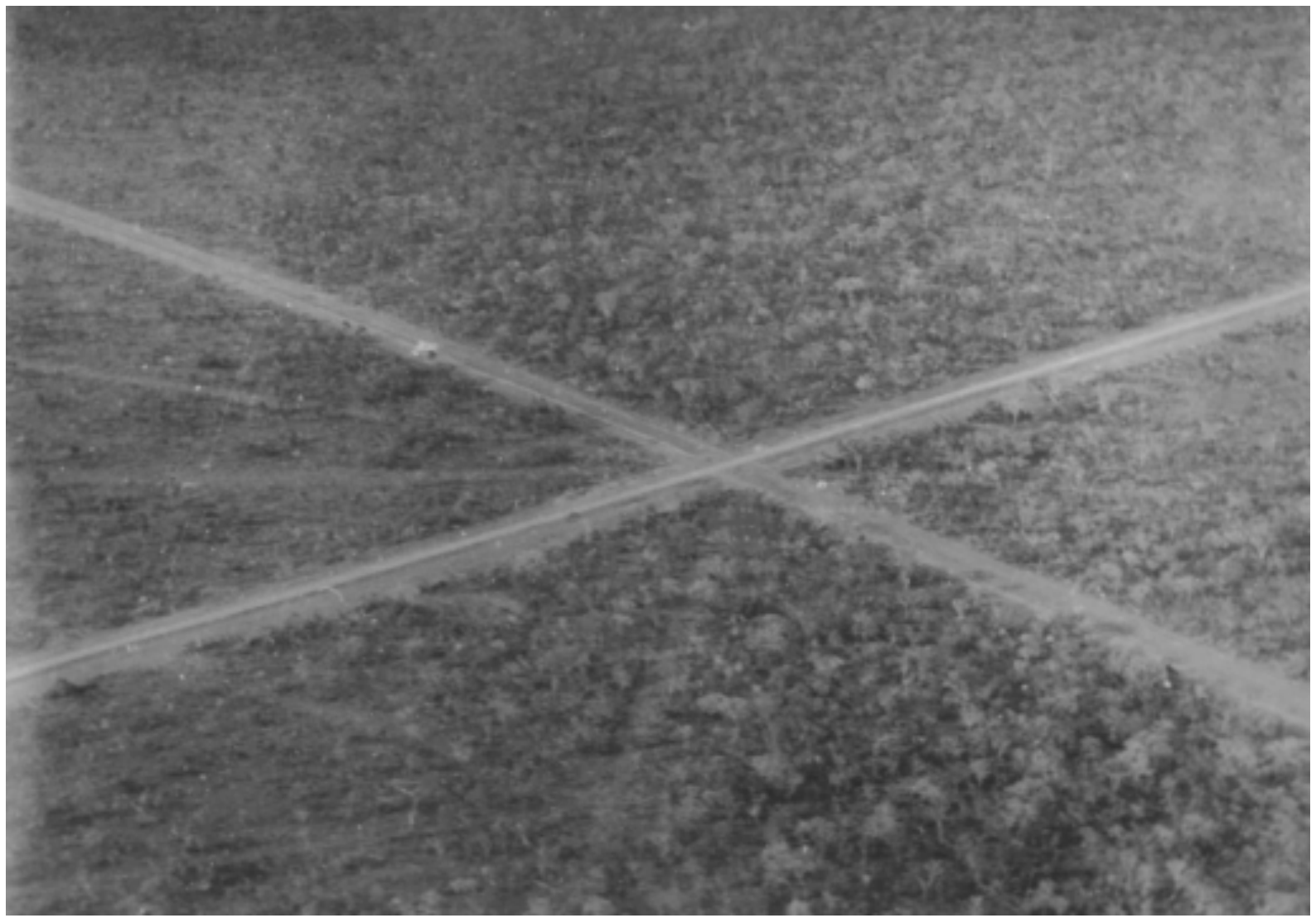

Brasília de Lúcio Costa (cruz): gramática de superfície

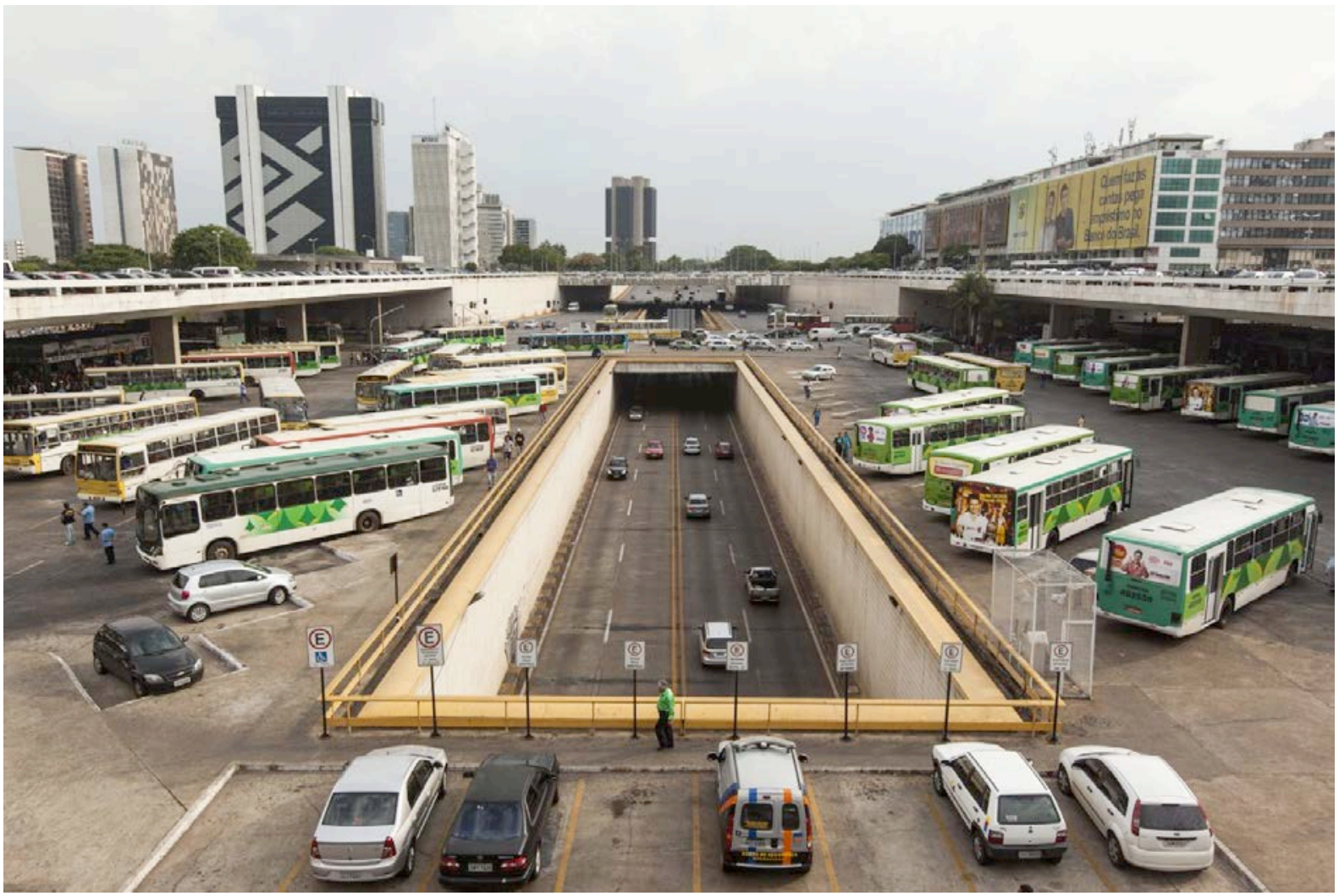

Rodoviária de Brasília: gramática profunda 
0 rizoma assume formas muito diversas, desde a extensão superficial ramificada em todos os sentidos à concreção em bulbos e tubérculos... qualquer ponto de um rizoma pode ser conectado a qualquer outro e deve ser conectado... a modos muito diferentes de codificação (biológicos, políticos, econômicos, etc.) que põem em jogo não apenas regimes de signos diferentes, mas também os estados de coisas de diferentes status... Uma multiplicidade não tem nem sujeito nem objeto, somente determinações, grandezas e dimensões que não podem aumentar em número sem a multiplicidade de mudança na natureza... ${ }^{156}$

Na sequências narrativas do rizoma, na apresentação de Mil Platôs, Deleuze e Gattari descrevem um emaranhado de conceitos que sobrevivem conectados dentro da estrutura aberta do livro. ${ }^{157}$ Desde os princípios de conexão e de heterogeneidade ao princípio de multiplicidade, do princípio da re-significação de rupturas ao princípio da cartografia e decalcomania, o emaranhado partilha da razão do rizoma e esses, impressionantemente, com a cidade. Proporia até uma leitura do rizoma deleuziano, utilizando-o como um "guia de ruas", como uma estratégia de mapeamento da experiência urbana e apostaria encontrar uma lógica, não textual ou conceitual, mas uma fantástica descrição de uma certa existência na e da cidade. Me resguardarei aqui na leitura de Ignasi de Solà-Morales sobre a dobra deleuziana, na sua crítica ao minimalismo formal em arquitetura, que reafirma:

\begin{abstract}
Para a arte e a arquitetura a dobra é o oposto da redução e eliminação típica do minimalismo. A dobra dá origem a acidentes e irregularidades, e essas irregularidades inscrevem-se, instalam-se na superfície, formando pregas. Essas inscrições superficiais são o esporão e a ocasião de todas as proliferações de qualquer processo de multiplicação que inscreve-se na superfície. Mapas, tatuagens, linhas de contorno, erupções e separações são sinais das diferenças e multiplicidades que sustentam um pensamento que não é nem dialético nem dualista, mas plural e relacional. ${ }^{158}$
\end{abstract}

É irônico verificar como Solà-Morales limitou-se a comentar o objeto da arquitetura no seu isolamento, referendo-se aqui à sua manifestação tectônica e perdendo assim a oportunidade de relacionar a dobra deleuziana além a materialidade da arquitetura, com o próprio fenômeno-experiência do espaço-cidade. Se as suas referências no texto são

\footnotetext{
${ }^{156}$ Gilles Deleuze e Félix Guattari. A Thousand Plateaus: Capitalism and Schizophrenia. Minneapolis: University of Minnesota Press, 1987, p. 7-8.

${ }^{157}$ A proposta de Mil platôs é exatamente esta: aborde o livro da sua maneira e a partir de qualquer ponto, pois o sentido linguístico do sujeito determinará uma lógica dentro da coleção de ideias, isto é, como vários caminhos díspares dentro da cidade e, mesmo que você se perca, a cidade vai sempre constituir uma lógica das orientações.

${ }^{158}$ Ignasi de Solà-Morales. Surface Inscriptions, in Cynthia C. Davidson (editora). Anything. Cambridge, Mass.: The MIT Press, 2001, p. 237.
} 
Eisenman, Tschumi e Greg Lynn com as suas investigações formais e semióticas, diria que a dobra deleuziana se manifesta mais fortemente no trabalho do OMA/Rem Koolhaas, especialmente se olharmos a dobra não como elemento visual (o vinco, a prega), formal ou até semiótico da arquitetura, mas sim como elemento estruturador do espaço e gerador das suas relações. Num caso mais próximo, o trabalho de Paulo Mendes da Rocha articula relações espaciais, integrando a arquitetura com o seu território e a experiência fenomenológica em uma única entidade totalizante. Como poucos, Mendes da Rocha compreendeu que as virtudes tectônicas do objeto ultrapassam as limitações da imagem formal para servirem ao mandato primordial da arquitetura, que é a sua vocação espacial-organizadora: a arquitetura como estruturadora do lugar. Em Mendes da Rocha não existe redução e eliminação, como se supõe. Os espaços são gerados dentro de um virtuosismo técnico que negocia ao mesmo tempo programa, estrutura, materialidade, tempo e lugar. Neste caso a dobra se apresenta desaparecida como ícone, mas presente como experiência. No caso de OMA/Koolhaas, a dobra se manifesta simbolicamente, pois é sempre facilmente reconhecida dentro da imagem do edifício, servindo como um marco, como um elemento pedagógico da arquitetura.

De uma forma extremamente consistente a dobra se apresenta de maneira frequente no trabalho de OMA/Koolhaas, assinalando uma continuidade de questionamento de um corpo arquitetônico singular. A meu ver esta continuidade é fruto da experiência hiperurbana do próprio Koolhaas, que alimenta assim a sua intensa e internacional bateria de assistentes. A intenção é de constantemente estabelecer re-significações das rupturas no cerne da estrutura convencional do edifício, para assim manter um grau de criticalidade no processo de reinvenção da vida urbana contemporânea. Como um vírus que se multiplica intermitentemente, este questionamento ultrapassa os anos e os projetos para assumir uma consistência conceitual que informa diretamente o desenho. Podemos reconhecer a dobra como gesto projetual no Kunsthal (duas rampas internas negociando dois níveis), na estação do TGV de Lille (um plano inclinado ligando a cidade antiga ao novo centro), na Très Grande Bibliothèque (uma série de vazios organizando a coleção e articulando a circulação), na Biblioteca de Seattle (um plano contínuo interrompido por cortes e bolsões de sociabilidade), na torre do CCTV (o próprio edifício é uma grande dobra), na loja Prada no Soho (uma paisagem interna dobrada em si conectando as duas entradas da loja), a casa de Bordeaux (com o elevador central re-programando constantemente a vida interna), e assim por diante.

Tais projetos mencionados acima compreenderam o papel da dobra no 
desenvolvimento do projeto - como o edifício pode se desenvolver para além da responsabilidade de resolver programas internos. Nesta linha de pensamento, o Kunsthal de Roterdã absorve outras tarefas urbanas, negociando relações entre dentro e o fora, mas também entre diferentes condições da cidade. O terreno onde o Kunsthal está localizado é constituído de um talude entre um antigo dique (Westzeedijk) e um dos parques principais da cidade (Museumpark). Ao longo do dique passa uma via expressa que liga o leste ao oeste da cidade, formando uma barreira entre o parque e o rio Maas, enquanto que em torno do Museumpark se encontram as instituições culturais mais importantes da cidade adjacentes à Witte de Withstraat, uma rua que acumula cafés, restaurantes e equipamentos culturais. $\mathrm{O}$ Kunsthal, além da sua vocação institucional, serve de ligação entre estes dois desníveis significativos da cidade: o primeiro com uma vocação para o transporte regional, o segundo com um encargo local, de circulação e acomodação de pedestres. Duas ruas internas cortam o edifício facilitando a circulação de pedestres entres os dois níveis e recebendo as múltiplas entradas do museu.

Como na Rodoviária de Brasília, o Kunsthal - uma outra gramática profunda determina um espaço entre estes dois níveis, adensando a superfície urbana para assim criar os espaços culturais da instituição e ao mesmo tempo permitir uma série de novas conexões com a cidade: entre o dentro e o fora, servindo como ponte entre Westzeedijk e Museumpark. Desta forma, o OMA compreendeu a superfície urbana no seu potencial espacial, isto é, compreendeu que na sua espessura uma multiplicação de funções era possível, agora combinada com uma nova organização programática, proporcionando também um papel urbano para o edifício. Do lado do Westzeedijk, o Kunsthal serve de portão para o parque, um marco de entrada, e pelo lado do Museumpark oferece um destino protetor e aconchegante para aqueles que terminam um passeio, oferecendo uma visita ou uma taça de vinho no café do andar mais baixo, ao nível do parque. No processo o Kunsthal agencia a infraestrutura necessária para a circulação dentro-fora/acima-abaixo. 


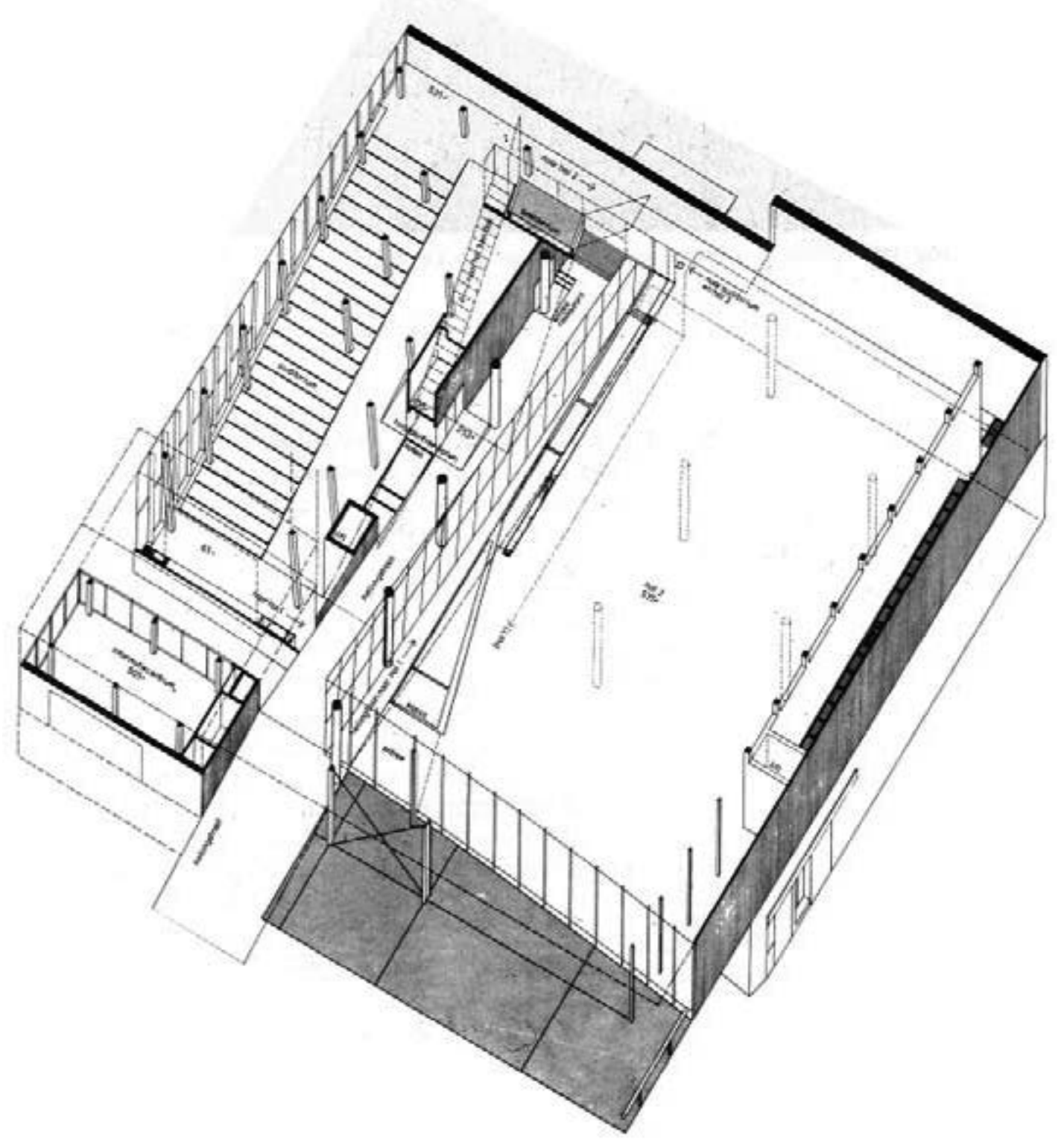

OMA/REM Koolhaas, Kunsthal, axonométrica, Roterdã (1992) 


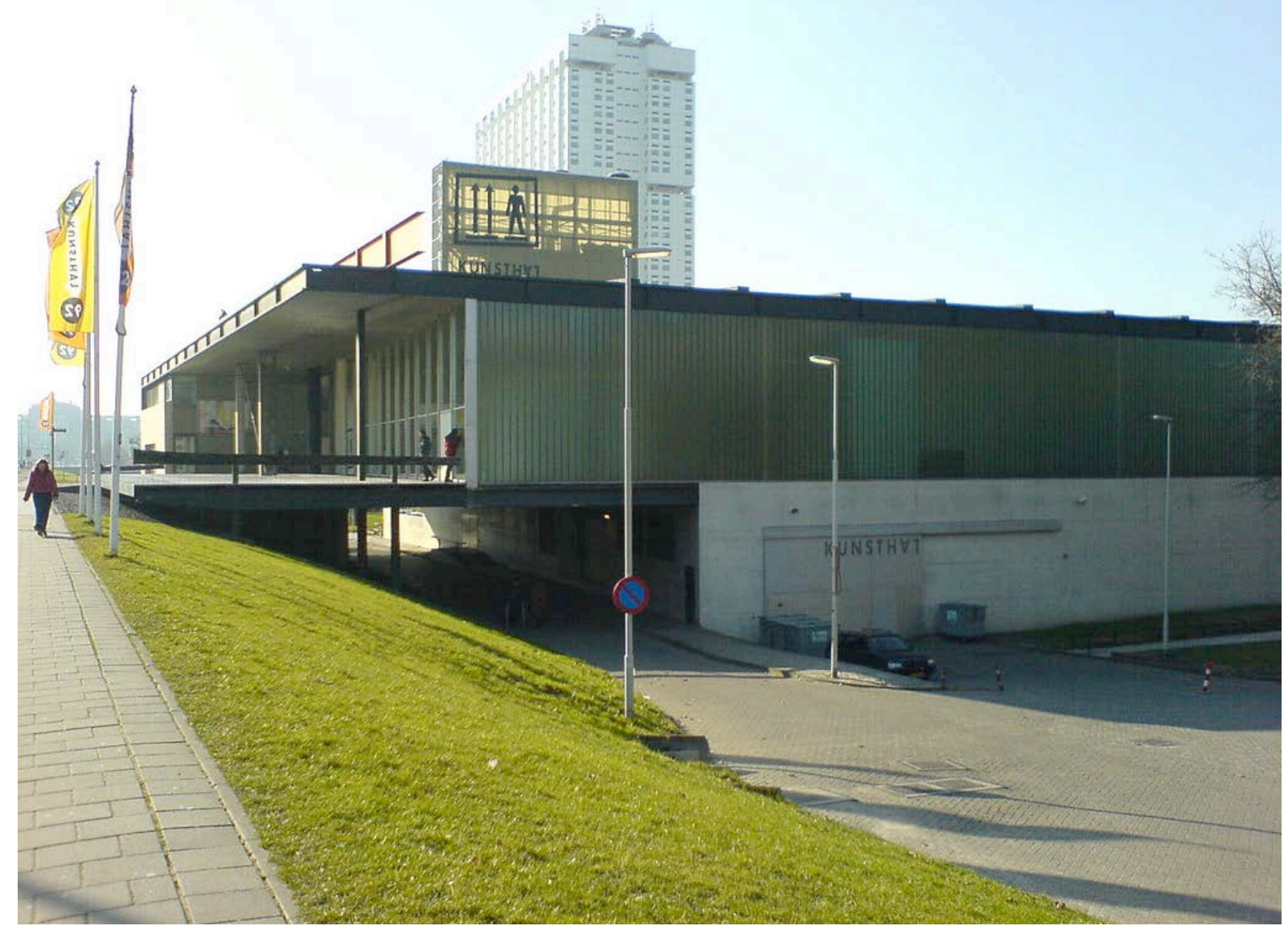

OMA/REM Koolhaas, Kunsthal, Roterdã, Vista do dique oeste (1992)

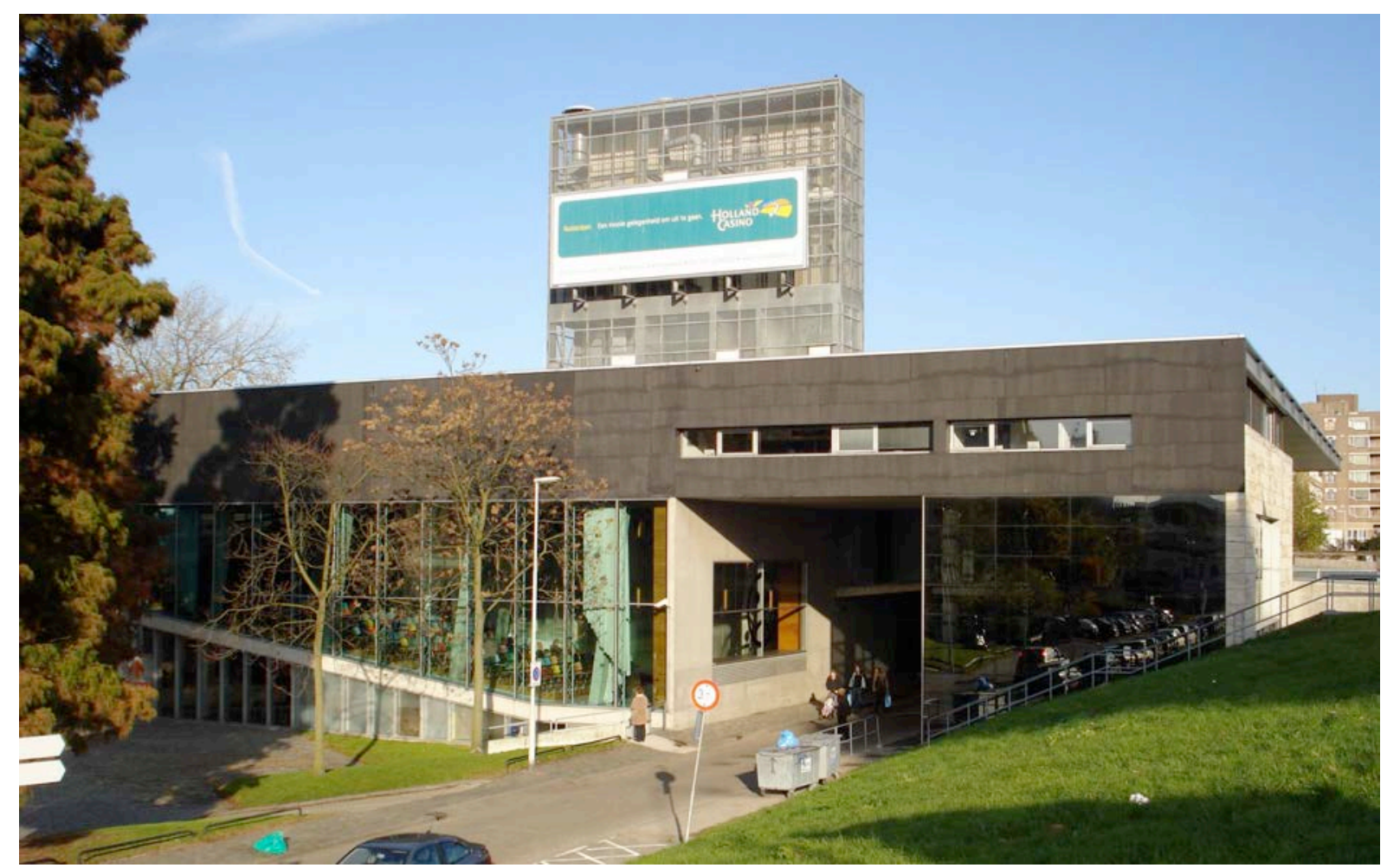

OMA/REM Koolhaas, Kunsthal, Roterdã, Vista do dique leste (1992) 
A dobra no gesto de OMA/Koolhaas não é resultado do preciosismo formal-visual da arquitetura tida minimalista, mas serve-se das suas potencialidades para reinventar o programa interno da arquitetura, propondo novas maneiras de viver pelas afinidades alternadas dos seus espaços internos, que no processo estabelece novas relações dentro-fora, reinventando o papel da arquitetura na cidade. OMA/Koolhaas considera este encontro do limite do edifício com o exterior de essencial importância pois a arquitetura sempre propõe um tratamento paisagístico responsivo (pelo belo trabalho de Petra Blaisse / Inside Outside), de interconexão e articulação com a cidade, como consequência recriando o espaço público urbano no processo, senão reorganizando a cidade em escala infraestrutural.

Para o OMA a dobra não é uma estratégia estética, como no minimalismo, mas sim um sistema que produz variações, invertendo sempre a expectativa da arquitetura, gerando uma superfície alterada pela sua própria evolução inusitada, mas sempre em resposta ao programa e não por vaidade. Poderia dizer que aqui o gesto é um "acidente intencional" transformando aquilo que se prega como convenção. Essas inscrições na superfície no projeto do OMA promovem uma nova performance do edifício, o que causa a proliferação dos processos de multiplicação: processos materiais, programáticos, estruturais, de ocupação, e visuais. Os espaços gerados são muito frequentemente espaços de fluxos suspensos e de indeterminações, abertos e responsivos para mais do que um programa, inter-relacionando experiências e economias, e oferecendo oportunidades múltiplas, espaços mais plurais e relacionais do que dualistas.

\section{$V_{-}$A superfície da praia}

\footnotetext{
Aqui, o termo 'paisagem' já não se refere aos aspectos de inocência pastoral, mas invoca a matriz de funcionamento de um tecido conectivo, que organiza não só os objetos e os espaços, mas também os processos dinâmicos e eventos que se movem através deles. ${ }^{159}$
}

Já falamos aqui de Barravento de Glauber, e que este se passa quase que exclusivamente na praia. A praia em Barravento não compõe somente o cenário mas torna-se central à narrativa a partir do momento em que organiza a história e a cadência, o tempo da narração, virando de certa forma um ator dentro da estrutura do filme. No filme o termo "barravento" é expandido para além da ideia de paisagem, referindo-se não somente à agitação do mar e dos ventos, aos

\footnotetext{
${ }^{159}$ Alex Wall, 1999, op. cit. p. 236.
} 
movimentos dos coqueiros, mas também à superfície da areia como território de todas as possibilidades, lutas e contradições sociais. O mar aqui é o gerador de economias, mitologias e enigmas. A superfície da praia é a organizadora do universo de Buraquinho. Esta relação entre corpo e paisagem, entre o artista e o lugar, entre o tempo e o espaço no filme é o que faz da praia um mecanismo fundamental e integral na estrutura da narrativa.

No seu texto Programing the Urban Surface, Alex Wall descreve a superfície urbana como a somatória de todos os elementos que a ocupam e as conexões entre eles, contestando certas definições que consideram a superfície urbana somente os espaços não ocupados entre os objetos. Wall aponta a relevância da superfície estendida da cidade como base para a organização dos objetos e dos espaços urbanos, principalmente como uma matriz operacional que organiza as dinâmicas e os eventos que se movem através da superfície urbana, fazendo-a ativa e condicionadora das relações e interações entre os elementos que alimenta. Assim sendo, a superfície urbana é caracterizada como dinâmica e responsiva, "desdobrando eventos no tempo como uma emulsão catalítica" ${ }^{160}$ Aqui o que garante esta "dinâmica superficial” é a sua qualidade performática que depende dos seus atores para ativá-la e do aspecto temporal das respectivas ações.

Em um filme longa metragem o tempo é condensado ou expandido para favorecer o contar da história dentro do quadro convencional de aproximadamente duas horas. Os oitenta minutos de Barravento, por exemplo, descrevem o drama de uma vila de pescadores de xaréu, descendentes de escravos vindos da África, que traziam com eles os antigos cultos místicos associados ao candomblé. A história se concentra nos conflitos criados a partir do retorno de Firmino, que abandonara a vila fugindo para Salvador com o intuito de se livrar da pobreza. O seu retorno altera o ambiente sereno do lugar, criando conflitos não só sociais, mas também de natureza política, sexual e religiosa, afetando assim profundamente a estabilidade da cultura local. O drama completo de Barravento se sucede no espaço da praia, construindo uma imagem que descreve a possibilidade de vivência em integral relação com a sua superfície. A superfície da praia não serve simplesmente como elemento de cena do filme, mas representa a infraestrutura, o mecanismo operacional de toda uma cultura, uma sociedade e uma economia, tudo sucedendo-se, transformando-se e intricadamente evoluindo sobre um mesmo plano.

\footnotetext{
${ }^{160}$ Idem, p. 241.
} 
No caso de Copacabana a praia serve como um modelo geral para o espaço público gerando, na riqueza de suas superfícies flexíveis e programáveis, novas infraestruturas urbanas. A praia como um modelo de estratégia espacial promove dinâmicas urbanas mais atraentes para os moradores da cidade, negociando espaços entre a presença física dos edifícios e outros objetos urbanos como ruas, calçadas, ou sistemas de luz, transformando a estagnação do diagrama arquitetônico, ditador muitas vezes das relações urbanas em espaços públicos. A praia urbana enquanto espaço articula em si uma "gramática de profundidade" mesmo que predominantemente "superficial".

Talvez na praia habite a consciência popular como uma paisagem deslocada, marginal e encantadora - “a praia está lá!” - realizando um papel autônomo e independente da cultura da cidade e assim seja olhada como um anacronismo a ser explorado somente pelo ócio e pelo turismo. Mas segundo a caracterização de Alex Wall - uma superfície dinâmica e responsiva, desdobrando eventos no tempo como uma emulsão catalítica - e abençoada pelas promessas do rizoma deleuziano - espaços de fluxos suspensos e indeterminados, abertos e responsivos para mais do que um programa, inter-relacionando experiências e economias, e oferecendo oportunidades múltiplas, espaços mais plurais e relacionais do que dualistas - a praia pode ser vista como modelo exemplar para um novo paradigma da superfície urbana, pois já traz embrenhada em si todas estas qualidades.

No caso de Copacabana, a praia encontra-se na essência dos mecanismos urbanos. Se por um lado está posicionada na orla, então num território aparentemente marginal e restrito, fora das convivências urbanas mais intensas, as dinâmicas geradas pelas praias da zona sul do Rio de Janeiro são responsáveis pelas relações operacionais mais profundas: desde a identidade cultural do carioca até os fundamentos econômicos que geram a cidade, tudo resultado de uma superfície carregada de potencialidade, dinâmica e aberta, com seus fluxos indeterminados, com a sua pluralidade abusada, com o seu tempo próprio, respondendo sempre às forças da natureza e à energia do seu povo. A eficácia desta superfície maleável e temporal é comprovada e respeitada no interior daqueles que a confrontam cotidianamente: não existe invasão permanente nas praias do Rio, como observamos nos seus morros.

Mas a praia não é disjunta e abstrata, mas sim apresenta-se como possibilidade de reinvenção urbana. Dentro dos processos inconscientes da cidade, resultado dos movimentos humanos mais enérgicos do que os próprios objetos urbanos, observamos o modelo da praia se manifestando na cidade de várias maneiras: por fragmentos momentâneos, por específicas 
intenções ou por condições inusitadas. O Minhocão, por exemplo, se manifesta como uma praiapaisagem, com uma mesma superfície transformando-se em infraestrutura de produção durante a semana (tráfego) para uma base de ócio e lazer nos fins de semana. A marquise do Ibirapuera, uma outra superfície estendida, articula a comunicação entre os principais edifícios do parque, mas ao mesmo tempo oferece o aconchego da sombra ou a proteção da chuva numa suavíssima inclinação que permite um atravessar dinâmico pelo espaço, mas que também recebe os mais variados programas acidentais desde a patinagem e a brincadeira de bola, até à venda de pipoca e algodão doce.

O térreo do Copan, na sua resposta singular à topografia da cidade, negocia os vários níveis entre a arquitetura e cidade sem rupturas de passagem como degraus ou cercas, sem emendas, permitindo uma sinergia completa com a cidade através do seu programa socialcomercial e com a sua multiplicidade de entradas e saídas de moradores ou pedestres criando uma arquitetura camuflada em urbanismo que convida a cidade para dentro de si. ${ }^{161}$ Além de Niemeyer e da singularidade do seu caráter visual e simbólico, o Copan é o resultado de uma condição complexa da cidade. Ele não está limitado ao seu interior, mas em vez disso, estabelece relações com os seu contexto através da contaminação mútua entre o edifício e a cidade, estendendo-se visualmente na vertical, mas também horizontalmente através da continuidade da sua superfície urbana e das suas múltiplas inter-relações entre o edifício e a cidade. Estas condições descritas aqui auxiliam na construção de praiapaisagem e avançam a sua estratégia enquanto desenho.

Em se tratando da praia e de todos os exemplos acima citados há de se notar um fator determinante, que, por conta da sua não-objetidade, pode passar desapercebido: o tempo. Um dos aspectos mais essenciais de Dust Breeding foi o fato de que o tempo passou, permitindo assim a acumulação intensa da poeira, fator capital para a existência do trabalho e para a desmaterialização do objeto anterior, o Grande Vidro. Se por um lado a superfície urbana oferece um espaço para que tais relações ocorram em conformidade com as suas próprias dinâmicas, há de se considerar o tempo: tempo cronológico (no caso do Minhocão, diferentes horários para diferentes usos), ou tempo fenomenológico (aquele que se aproxima dos sentidos, das percepções, da experiência subjetiva).

A consciência simultânea destes dois tempos se faz necessária para a determinação do desenho urbano. O primeiro organiza as atividades de maneira eficaz e pragmática, o segundo

\footnotetext{
${ }^{161}$ De maneira semelhante ocorre com o térreo do Conjunto Nacional.
} 
estabelece as regras onde os ativos sociais e psicológicos entram em operação. O engajamento do corpo social é essencial para o sucesso de qualquer espaço urbano. É fantástico observar que a superfície da praia, na sua aparente homogeneidade, acomoda as mais diversas atividades simultaneamente, variavelmente de um dia para o outro, possibilitando uma ocupação riquíssima do espaço, seja por razões ociosas, comerciais, esportivas, românticas, políticas, criminais, de passagem, de diversão, etc. Se tentamos compreender como tais trocas e dinâmicas ocorrem, dentro da sua rica diversidade e relativamente fácil operabilidade, dia após dia, em uma mesma superfície, organizada pelos mesmos objetos urbanos imutáveis, concluímos que a possibilidade da praia como superfície urbana se dá pelas qualidades temporais do espaço. A experiência de se caminhar no Minhocão, uma superfície urbana elevada, causa um certo desconforto pela separação do solo urbano abaixo. Para alguns a experiência é agradável, para outros desafiadora, não tão tranquila assim. Como tais experiências tão díspares se sucedem em uma mesma superfície na cidade? É tudo uma questão de tempo - como o tempo molda o espaço, como o tempo se multiplica em vários tipos de tempos - por exemplo, o tempo do momento: "Naquele momento, por causa de uma situação qualquer, não era agradável passar por aquele lugar.” Resta saber como podemos traduzir o tempo, esta consciência do tempo (ou diferentes tipos de tempos) em um desenho para a cidade. 


\section{9_PRAIAPAISAGEM}

Talvez a síntese das técnicas em paisagismo, arquitetura e urbanismo em uma forma híbrida destas práticas possa permitir a invenção de novos tecidos urbanos, flexíveis e maleáveis, de novas paisagens. Essa superfície dinâmica e estruturadora pode ser a única esperança de resistirmos aos excessos da cultura popular - a mobilidade inquieta, o consumo, a densidade, os resíduos, o espetáculo, e a informação -. absorvendo e redirecionando os episódios alternados de concentração e dispersão causados pelo movimento volátil de investimentos de energia e capital. ${ }^{162}$

\section{I_Arquitetura como praia}

Como a praia propõe uma rica gama em potencialidades de experiências e espaços para engendrar modelos atuais de espaços urbanos, assim algumas arquiteturas carregam o potencial articulador de praiapaisagem na cidade. Nestes projetos-praia, a manifestação da experiência da praia explicita-se através das qualidades propostas aqui. Neste momento, um diálogo é construído entre praia e arquitetura, uma apreendendo da outra, e assim esticando ao máximo as perspectivas mútuas de contribuição. Em tais casos fica evidente o caráter híbrido resultante entre praiapaisagem e arquitetura, sinalizando o momento em que a praia se volta à cidade e, num esforço de estampar-se na vida urbana influi significantemente nas qualidades intrínsecas do edifício, abrindo-o às novas dinâmicas e demandas da metrópole contemporânea a partir do comprometimento do edifício com o espaço público, definindo agora uma arquitetura como praia. Notadamente distinguimos tais projetos-praia como alívios urbanos altamente utilizados e celebrados pelos seus cidadãos. O SESC Pompéia ou o belvedere do MASP de Lina Bo Bardi não seriam verdadeiras praias urbanas? E a Marquise do Ibirapuera ou o Minhocão num domingo de sol? Estes projetos são, direta ou indiretamente, alusões à praia. Não a praia convencionada pela extensão de uma superfície de areia banhada pela água do mar, mas sim referências ao mitológico universo praiano, ao costume de ajuntamento humano numa superfície envolvente, sob intensa produção e troca cultural contínua, com as liberdades do convite de um espaço público atraente e investido especialmente nas relações humanas.

Os espaços públicos que consideram critérios pautados em táticas análogas à da praia formam a base de praiapaisagem. A condição de praiapaisagem pode então ser traçada

\footnotetext{
${ }^{162}$ Alex Wall, "Programing the Urban Surface”, James Corner (org.), Recovering Landscape: Essays in Contemporary Landscape Architecture. New York: Princeton Architectural Press, 1999, p. 233, tradução nossa.
} 
historicamente através de exemplos que não são necessariamente paisagens praianas. Esses projetos-praia são manifestações em espaços públicos desprovidos da totalidade que a praia apresenta, mas que mesmo assim assumem qualidades inerentes à ela. Estes espaços oferecem a esperança dos espaços humanistas da praia em situações frequentemente antagônicas ao contexto costumeiro da praia. São na sua maioria projetos localizados em centros urbanos maiores, desprovidos de um corpo de água com um horizonte e a ausência de uma paisagem de areia, não possuindo na maior parte nenhuma materialidade comparável à praia, apresentando superfícies duras ao invés de superfícies moles. Na sua maioria são espaços avizinhados com outros edifícios e com uma periferia explicitamente programada. Assim sendo, replicam o âmbito da praia, a partir de meios não naturais, como dispositivos urbanos efetivos, pois alcançam o sucesso público pela tradução eficaz de condições análogas encontradas na praia através de modelos de desenho aplicados, constituindo assim praiapaisagens legítimas.

No caso da Piazza Del Campo de Siena, na Toscana italiana, a geometria perimetral da praça forma uma quase meia-lua, uma forma em “ $D$ ”, produzindo uma inclinação sutil e natural da topografia, sugerindo direção e conforto, pois facilita o sentar e o ficar, bem como a circulação. Com um adequado pavimento de tijolos montados em cunha, o riquíssimo entorno enquadra o espaço com as suas arquiteturas e seus respectivos programas (cafés, lojas, etc.), gerando um espaço público altamente preciso, enfatizando os aspectos humanistas do urbano que naturalmente atraem as pessoas para se encontrarem, circularem, ou estarem no lugar em plena interação ou simples contemplação. Estes aspectos humanistas podem ser medidos pela escala apropriada, a materialidade, o tempo histórico das coisas, a localização avantajada no contexto da cidade e pela conduta que as gentes aceitam e ocupam o espaço. $\mathrm{O}$ mesmo se sucede, por exemplo, com o Sheep Meadow do Central Park, ou a Place Georges Pompidou em Paris: espaços estes íntegros com o seu entorno e equipados com qualidades duradouras semelhantes às de Siena, diferenciando-se pelos contextos, pelas variadas materialidades ou especificações. O que há em comum nestes espaços são exatamente a sua superfície ampliada, o seu enquadramento com uma rica dinâmica social gerada por arquiteturas programadas, mas também pela sutileza da inclinação desta superfície ampliada. A diferença essencial entre uma superfície totalmente plana e uma inteligentemente inclinada é que a plana provoca mais uma experiência de passagem, de mobilidade, de qualidade efêmera (por exemplo: Piazza de San Marco em Veneza), enquanto que a superfície inclinada, 
mesmo consentindo uma circulação apropriada, agencia ao mesmo tempo a pausa, o sentar, o ficar, o encontrar, o observar, o contemplar, atividades estas de um tempo devagar e demorado. Notamos que no caso das praias encontramos sempre uma inclinação natural da topografia em direção ao mar.

Mais recentemente os projetos da Ópera Nacional da Noruega em Oslo, de Snohetta, e também o Centro de Aprendizado Rolex na Suíça de Sanaa utilizam-se da estratégia da superfície estendida inclinada, investindo assim numa tática de praiapaisagem para articular a transição entre o edifício e o seu espaço público. No caso da Ópera Nacional da Noruega a superfície inclinada articula as diferenças topográficas desde o teto terraço do prédio da ópera até as margens do Fiorde de Oslo, articulado por uma série de rampas adjacentes ao mesmo. Esta estratégia de desenho organiza uma paisagem artificial no entorno do edifício, de certa forma evocativa dos fiordes, como um direto elemento arquitetônico integrado ao edifício, ao espaço público e à paisagem, formando uma única entidade. No caso do Centro de

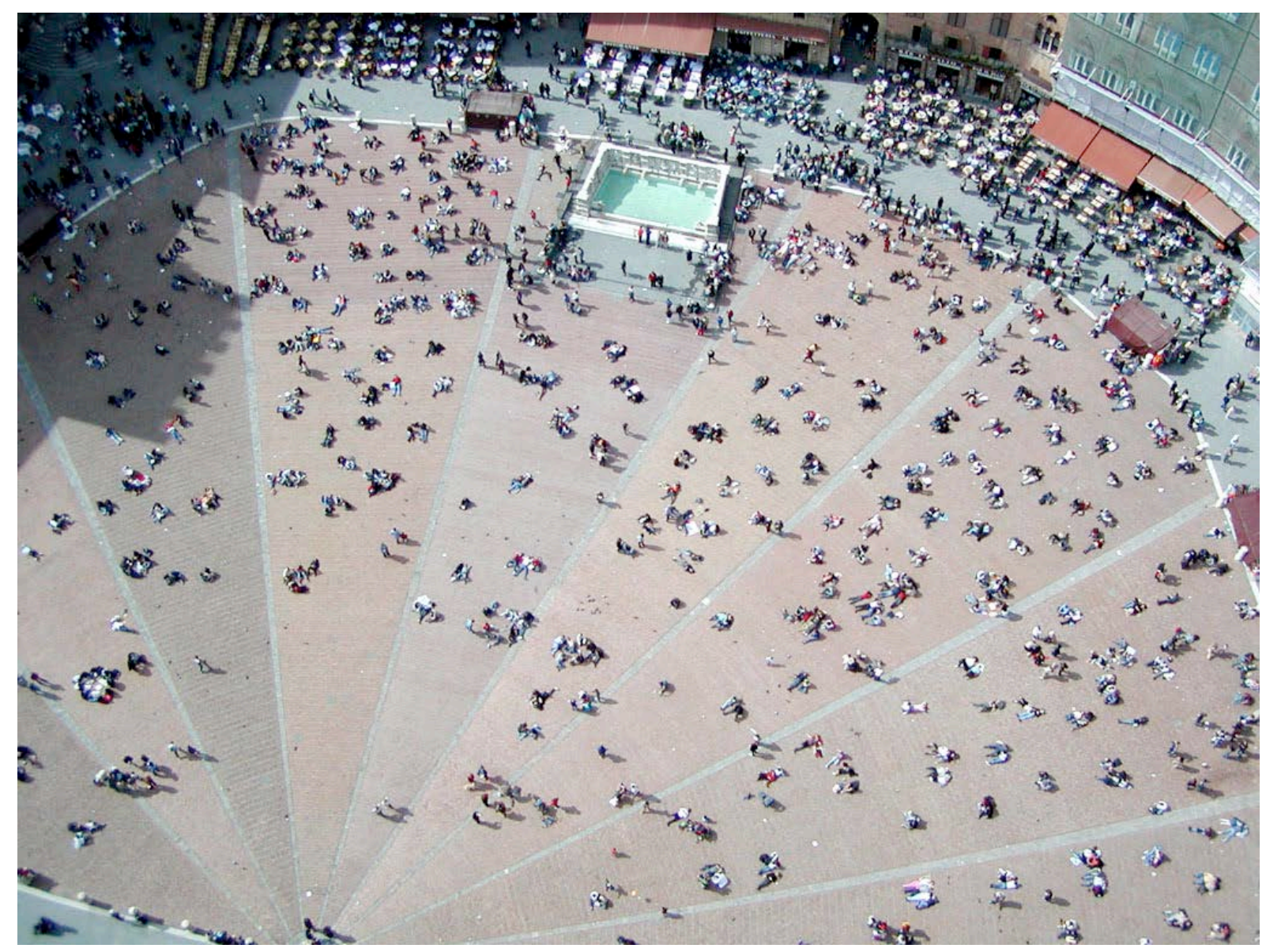

Praiapaisagem: Piazza Del Campo de Siena 
Aprendizado Rolex, a superfície se desenvolve numa relação mais complexa, pois responde delicadamente aos acessos e respectivos programas da arquitetura localizada acima. Esta topografia artificial envolvente se desdobra suavemente por ondulações e, de acordo com a complexidade programática, apresenta uma solução íntegra ao problema. A superfície se desenvolve a partir da natureza exterior plana do terreno para o interior do edifício, penetrando no seu segundo pavimento, e gradualmente até a cobertura, sugerindo assim o conceito de "arquitetura de superfície contínua". ${ }^{163} \mathrm{O}$ crítico Jeffrey Kipnis discutiu em Discrimination a tendência dos anos 1990 da exploração da ideia de uma arquitetura de superfície contínua, onde os planos determinadores do edifício se apresentam em contiguidade, dando a impressão de uma única superfície. O problema crucial foi que tal manifestação apresentou-se mais no plano representacional do que no estrutural e relacional, como se observa em vários projetos de MVRDV ou Diller Scofidio, reduzindo a arquitetura a uma simples imagem.

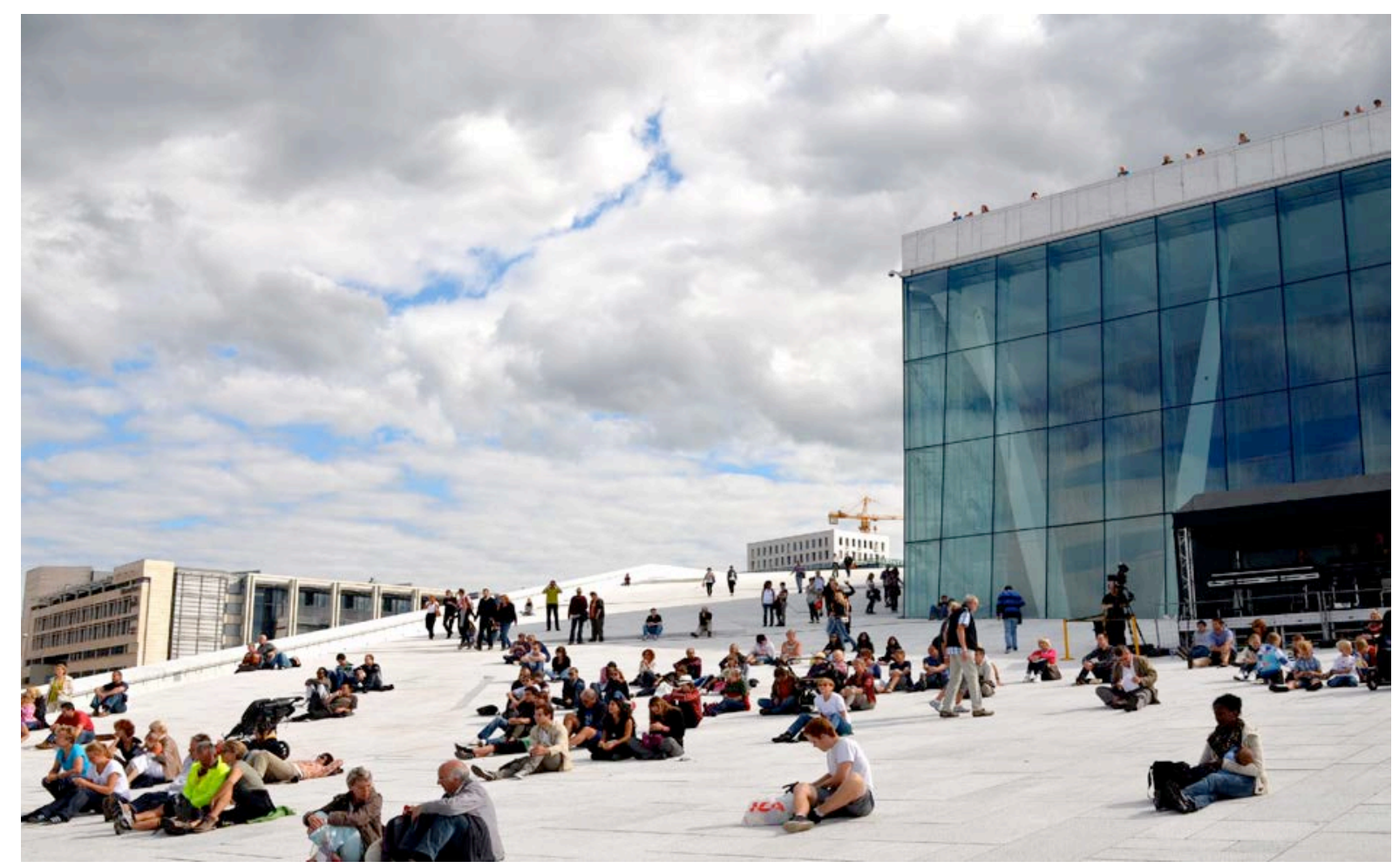

Snohetta, Ópera Nacional da Noruega, Oslo (2008)

\footnotetext{
${ }^{163}$ Discrimination, palestra de Jeffrey Kipnis na Escola de Arquitetura da Universidade Harvard, na qual discorre sobre o fenômeno da arquitetura de superfície contínua. Disponível em: $<$ http://www.gsd.harvard.edu/\#/media/discrimination-by-jeffrey-kipnis.html>. Acesso em: 7 de setembro de 2010.
} 


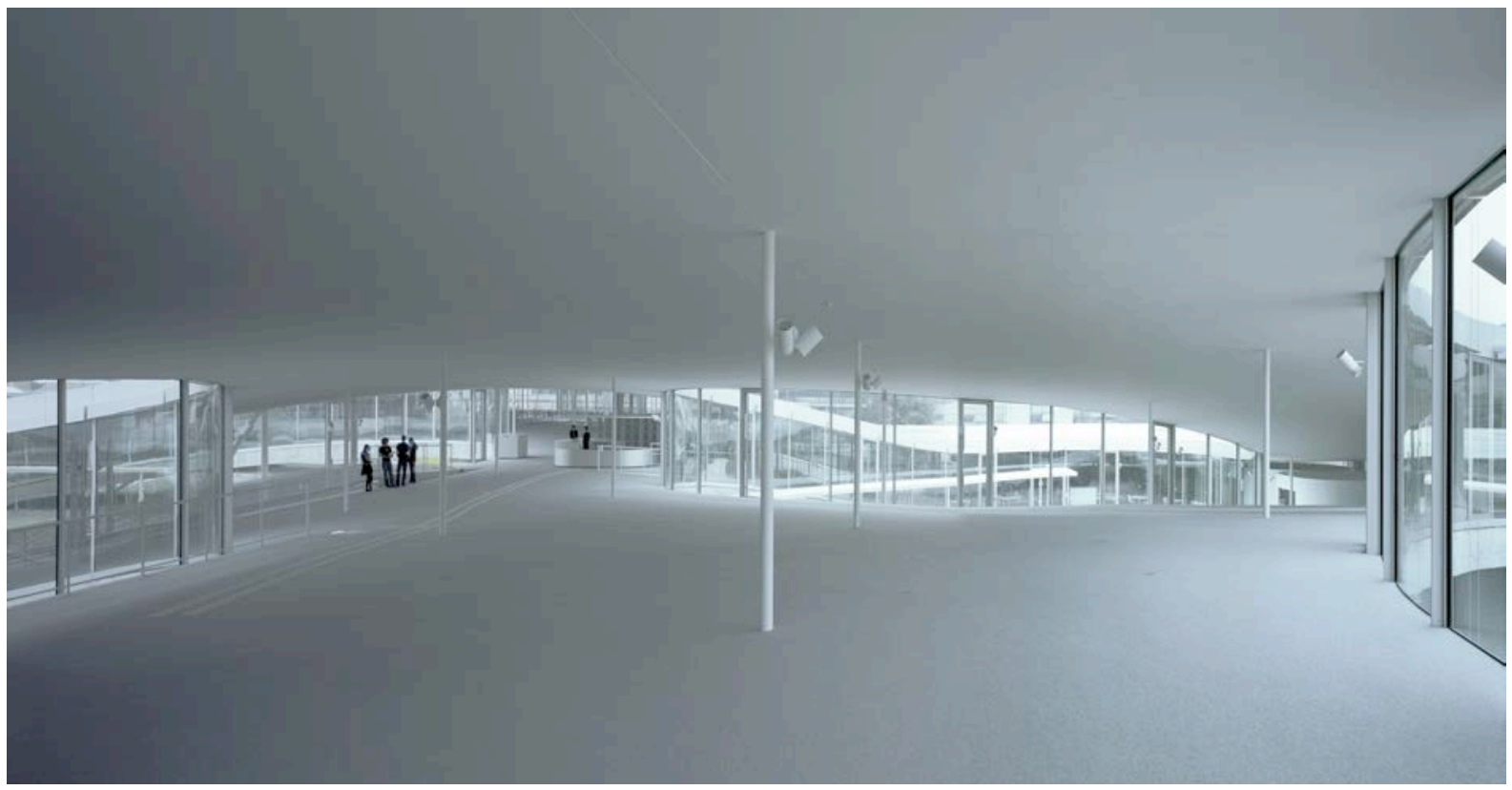

Sanaa, Centro de Aprendizado Rolex, École Polytechnique Fédérale de Lausanne, Suíça (2010)

A questão da superfície na sua condição primordial, isto é, estrutural, tem um papel central no desenvolvimento da modernidade no Brasil, a começar pelo Barroco, onde o foco dos planos independentes se perdem em favor de uma expressão contínua do espaço. Mais significantemente em Oscar Niemeyer, a superfície contínua se desenvolve como a totalidade do edifício, como por exemplo na Igreja de Pampulha. No repertório de Niemeyer, não só a utilização da superfície contínua virou um atributo estético, mas também assumiu um caráter estrutural, onde as distinções entre o dentro e o fora desapareceram, acomodando o programa e essencialmente gerando a experiência espacial para aquele que habita o espaço. Enquanto a superfície de Niemeyer marca essencialmente as qualidades formais e tectônicas do edifício, nas manifestações íntegras entre forma, materialidade e imagem, em Paulo Mendes da Rocha ela absorve radicalmente a qualidade territorial do sítio, transformando a arquitetura e o seu programa em um lugar. Para tanto, ele se utiliza de uma inteligência estrutural precisa na ampliação máxima do potencial do lote, como podemos observar, por exemplo, no Museu Brasileiro de Escultura. Ao mesmo tempo em que o programa do museu é articulado no subsolo, nas entranhas do terreno, um céu é criado a partir da laje exterior que se estende sobre a expansão total do lote, com o anfiteatro assumindo um papel duplo: teto do museu e espaço público externo. Aqui a superfície desaparece formalmente como imagem em prol das possibilidades fenomenológicas do espaço, sintetizadas pela experiência totalizante do corpo. A cobertura, contínua em relação ao seu entorno, interpenetrando a cidade, protege contra o 
sol e a chuva, enquanto o anfiteatro como superfície estendida cria um novo território habitável, uma praiapaisagem.

A consideração da arquitetura como praiapaisagem manifesta-se em outras situações dentro do contexto brasileiro, às vezes pela informalidade das transformações urbanas, como é o caso do Minhocão em São Paulo, onde uma infraestrutura dedicada ao tráfego de veículos transforma-se em "praia urbana” nos finais de semana, ou o deck do SESC Pompéia: uma praia artificial por excelência. Tais infraestruturas apresentam a flexibilidade programável que permitem a sua ocupação constante, mas por usos informais e diferenciados. Reiterando a qualidade da inclinação da superfície da Piazza Del Campo de Siena, o térreo do Edifício Copan atende aos critérios de praiapaisagem devido à presença de uma superfície contínua com uma precisa articulação geométrica em relação ao lote, com uma perfeita adaptação à topografia do lugar, à sua capacidade articuladora do programa (galeria / espaço público interno / circulação) e a resolução dos acessos pontuais do edifício. 


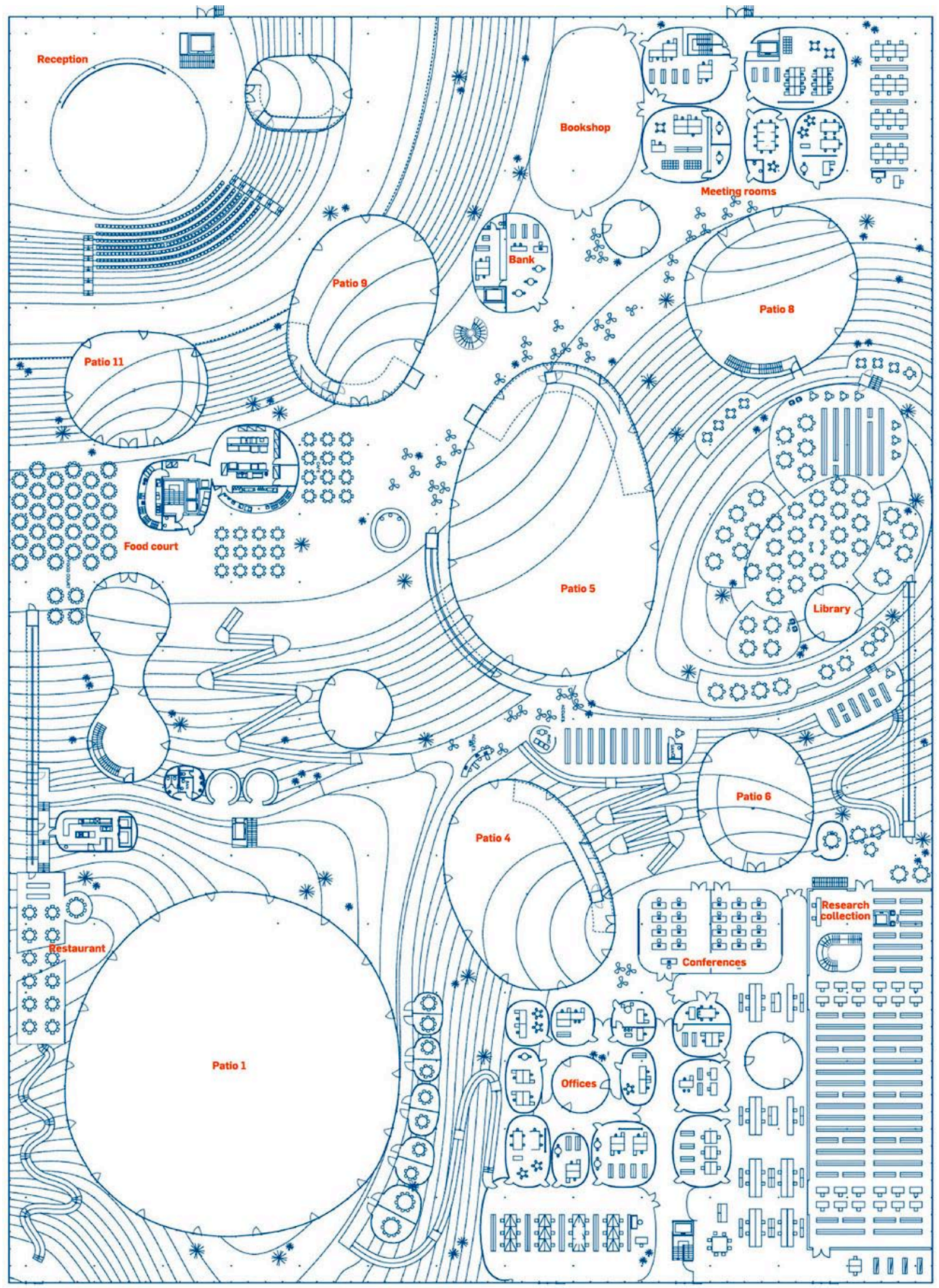

Praiapaisagem: Sanaa, Centro de Aprendizado Rolex (planta), École Polytechnique Fédérale de Lausanne, Suiça (2010) 


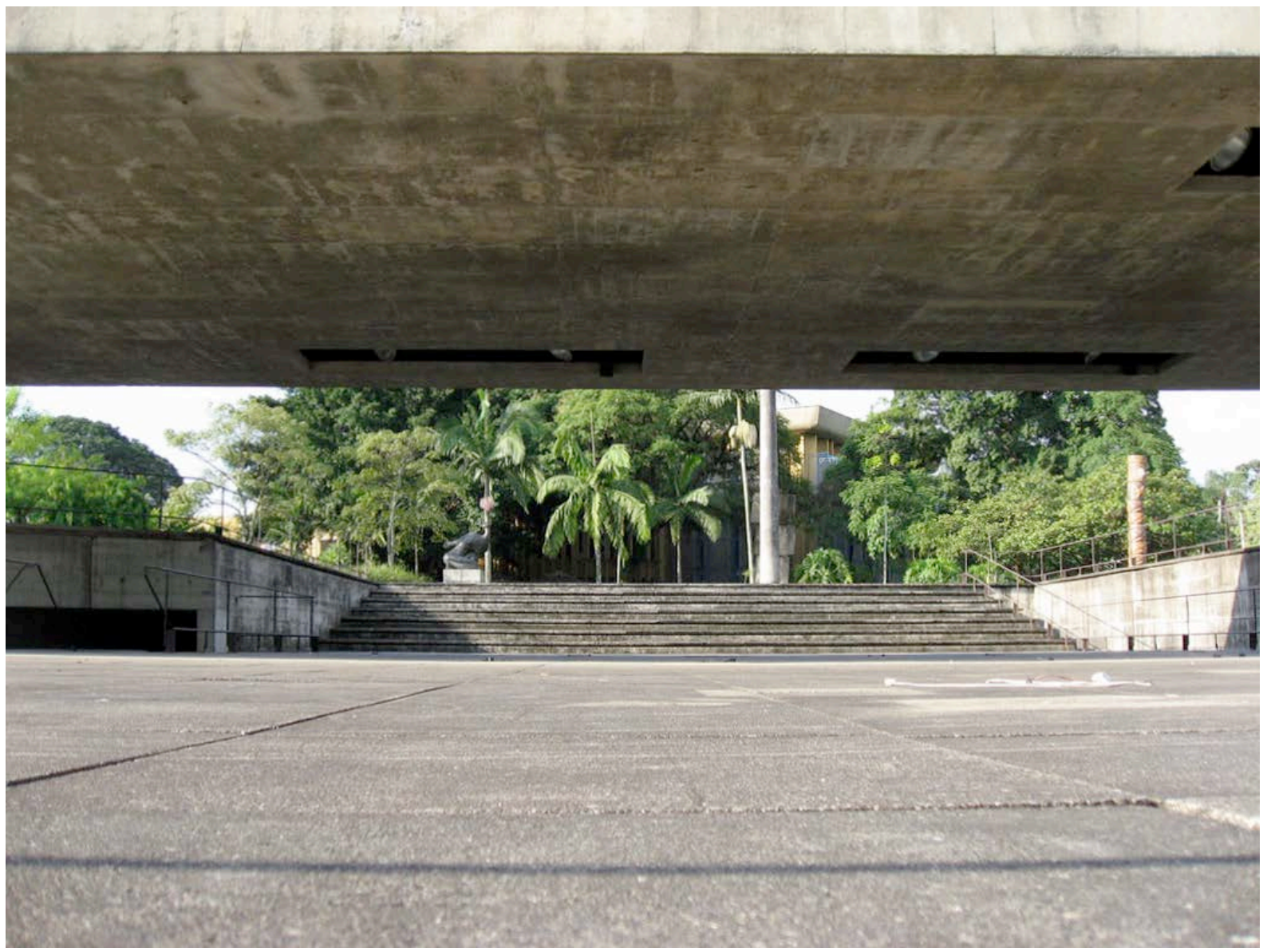

Paulo Mendes da Rocha, Museu Brasileiro de Escultura, São Paulo (1986)

A experiência no interior do Copan altera a perspectiva do habitante. O Copan é uma máquina de urbanidade - a experiência começa com a caminhada diária pela galeria do andar térreo para fazer compras, tomar um café , ou para ir ao trabalho. A passagem sinuosa estabelecida por Niemeyer negocia circulações contínuas dentro da geometria irregular do lote. O caminho interior segue a topografia ligeiramente inclinada original do terreno e todas as lojas comerciais são nivelados de acordo. As ligações entre o piso térreo e a cidade acontecem em convenientes pontos da elevação, sem a necessidade de alterar o plano da rua, criando uma conexão sem emendas entre o interior do edifício e a cidade. A galeria conecta-se aos edifícios vizinhos criando uma rede interior de caminhos públicos através dos quarteirões da cidade. A convergência de interesses de desenvolvimento (multiplicando as zonas comerciais) com a visão utópica do arquiteto (a criação de um espaço público coletivo) criou uma linha extremamente tênue entre territórios públicos e privados nesta tipologia particular. O resultado é uma subversão dos loteamentos típicos do território: contratempos, cercas, paredes e barreiras físicas entre o edifício e a cidade estão ausentes. Quando os seus habitantes 
descem de elevador, eles estão imediatamente posicionados na cidade, pois não existem mediações ou separações entre o interior e o exterior. A unidade espacial do térreo, com a sua continuidade e fluidez da circulação pública, é um modelo urbano exemplar para galerias do centro da cidade, onde a particularidade de cada edifício coexiste com uma organização urbana articulada e coesa. ${ }^{164}$

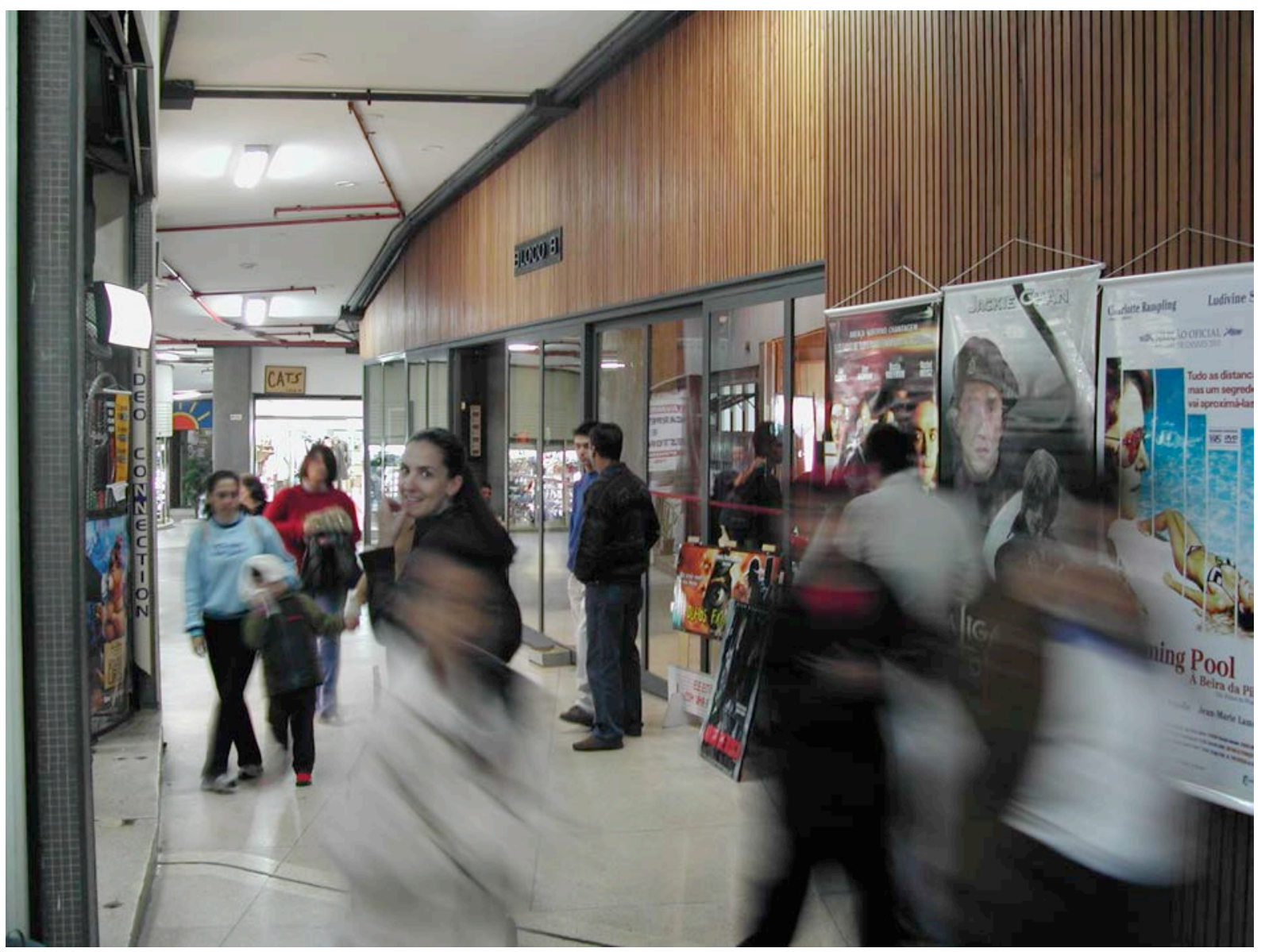

Térreo do Edifício Copan, São Paulo

Os paradigmas modernistas não correspondem mais à realidade urbana contemporânea. No entanto, para compreender o seu valor histórico, pode-se apoiar o contínuo desenvolvimento urbano de São Paulo, pois é a partir deste processo que a cidade se transformou. De todos os edifícios na cidade seguindo princípios semelhantes, apenas alguns mantêm uma dignidade urbana (dentre eles, o Conjunto Nacional). Tais projetos tendem a

\footnotetext{
${ }^{164}$ Fernando de Mello Franco, Eduardo Aquino e Karen Shanski. "Situation Copan: Mutual Contaminations". Complex Order: intrusions in public space. Winnipeg: Plug In Editions, 2009, pp. 12425.
} 
abrigar a classe média nas áreas mais exclusivas da cidade. O projeto para a revitalização do centro da cidade, do qual o Copan participa e se beneficia, resgata o projeto de modernização do país para uma cidade com propriedade compartilhada, exprimindo assim a complexidade social do território e seus relacionamentos, como podemos observar paralelamente na Copacabana de Roberto Burle Marx. Além de Niemeyer e da singularidade do seu caráter visual e simbólico, o Copan é o resultado de uma condição complexa na cidade. Ele não se limita ao seu interior, mas ao invés estabelece relações com seu contexto através das contaminações mútuas entre o edifício e a cidade, da mesma forma pela qual Copacabana negocia dinâmicas semelhantes entre a cidade e a sua paisagem.

Entretanto, de todos estes projetos-praia que se aproximam mais precisamente de praiapaisagem, talvez aquele que mais se identifique com a condição, seja a Marquise do Parque do Ibirapuera. A grande Marquise, com os seus 600 metros de extensão e 27 mil metros quadrados, é o elemento estruturador do urbanismo do parque, interligando o edifício da Bienal, o Palácio das Indústrias, Palácios das Nações e dos Estados, a Oca, o Museu de Arte Moderna (não previsto no projeto original), e o Auditório Ibirapuera. Como Burle Marx em Copacabana, a geometria livre da Marquise de Niemeyer cria uma nova lógica para o parque: um elemento infraestrutural com presença biomórfica conectando os seus principais edifícios, mas também criando um espaço público entre eles de uma generosidade imensa: não é simplesmente uma cobertura de passagem, protegendo da chuva, mas sim um autêntico recinto urbano. Esta disposição estruturada pela imagem de árvore/galhos, tão próxima de um idílio pela sua delicadeza e forte presença, tem as suas alusões da sua lonjura espalhada nas grandes paisagens brasileiras das longas praias ou as suas sombras liberais nas copas das imensas árvores amazônicas. A elegância da sua forma é acentuada pelo afinamento do seus balanços e pelo delicado posicionamento dos pilotis. A estrutura serve o parque como uma máquina atmosférica que produz um microclima controlado, independente das condições do tempo, o que permite a ocupação da Marquise a qualquer hora do dia, todos os dias do ano. A sua grande extensão assume a dimensão urbana de São Paulo, sendo sempre capaz de captar as massas frequentadoras do parque com conforto e, como Copacabana, torna-se o lugar onde todas as tribos se encontram: os visitantes de museu, os namorados, as famílias, os skatistas, os vendedores ambulantes, os michês, os adolescentes desocupados, os amantes da natureza e tantas outras tribos. 
Este espaço considerado vazio ou aberto, sem um programa específico definido, contradiz a crítica a Niemeyer de que é um arquiteto que valoriza a forma acima de tudo. Bem certo que o traçado da Marquise, quando vista do ar, é característica da estética do desenho de Niemeyer, mas quando experimentada no nível do solo, a forma se perde na sua extensão, criando uma paisagem em si mesma. Fica evidente, na vida da própria Marquise, que um mundo distinto é criado, com as suas atividades indeterminadas e suspensas, como Igor Guatelli tão bem categorizou:

Presença e ausência, intertextual, pois opera entre diversos "textos" definidos, traço, pois desprovido, ou liberto, de qualquer intenção inicial ou orientação quanto aos usos e funções possíveis, quanto aos referenciais semânticos ou predicações, e, ao mesmo tempo, elemento estruturador e desestruturante, pois, respectivamente, articulador (definição de um percurso) e ambíguo e emancipador - pois transita entre ser um elemento constituinte de um parque ou parte constituinte do conjunto arquitetônico edificado - esse espaço é capaz de potencializar ações e acontecimentos inesperados - "A ausência é a alma da pergunta", diz Jacques Derrida - por vezes, sem qualquer relação com os usos "dominantes" das edificações ao redor. ${ }^{165}$

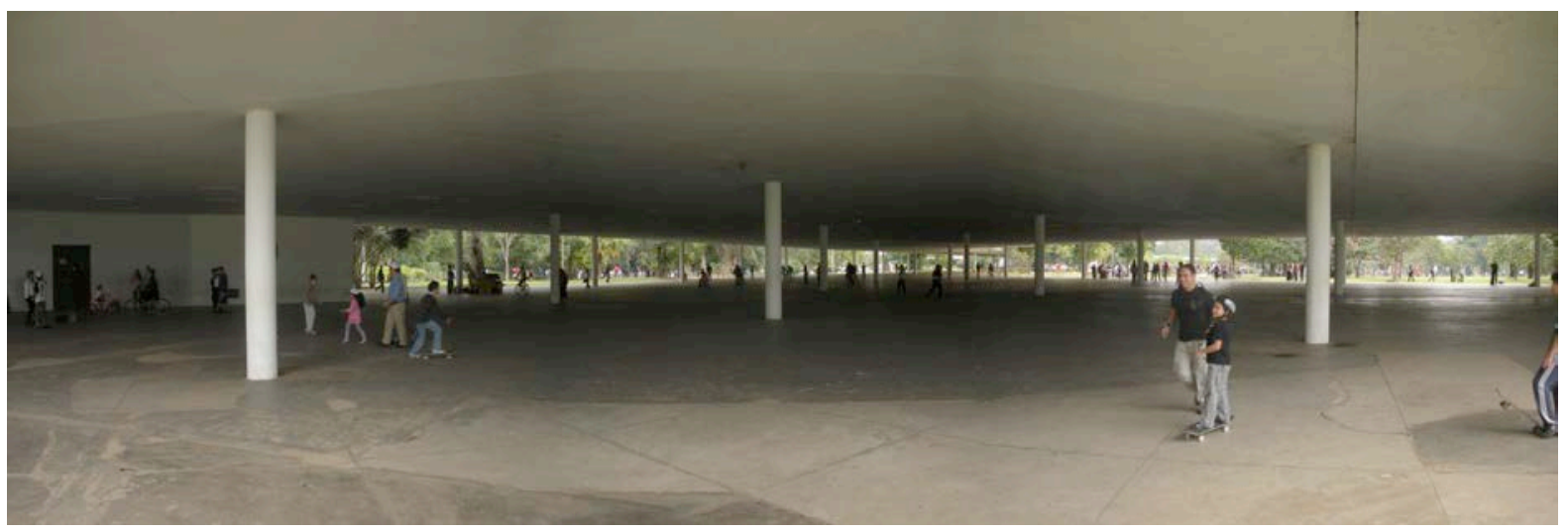

Oscar Niemeyer, Marquise do Parque do Ibirapuera, São Paulo (1954)

\footnotetext{
${ }^{165}$ Igor Guatelli, "A marquise do Parque Ibirapuera e manifestação do conceito derridiano 'entre': arquitetura como suporte de ações.", Arquitextos 070.05 (Março 2006). Disponível em: <http://www.vitruvius.com.br/revistas/read/arquitextos/06.070/371 >. Acesso em: 27 de novembro de 2013.
} 


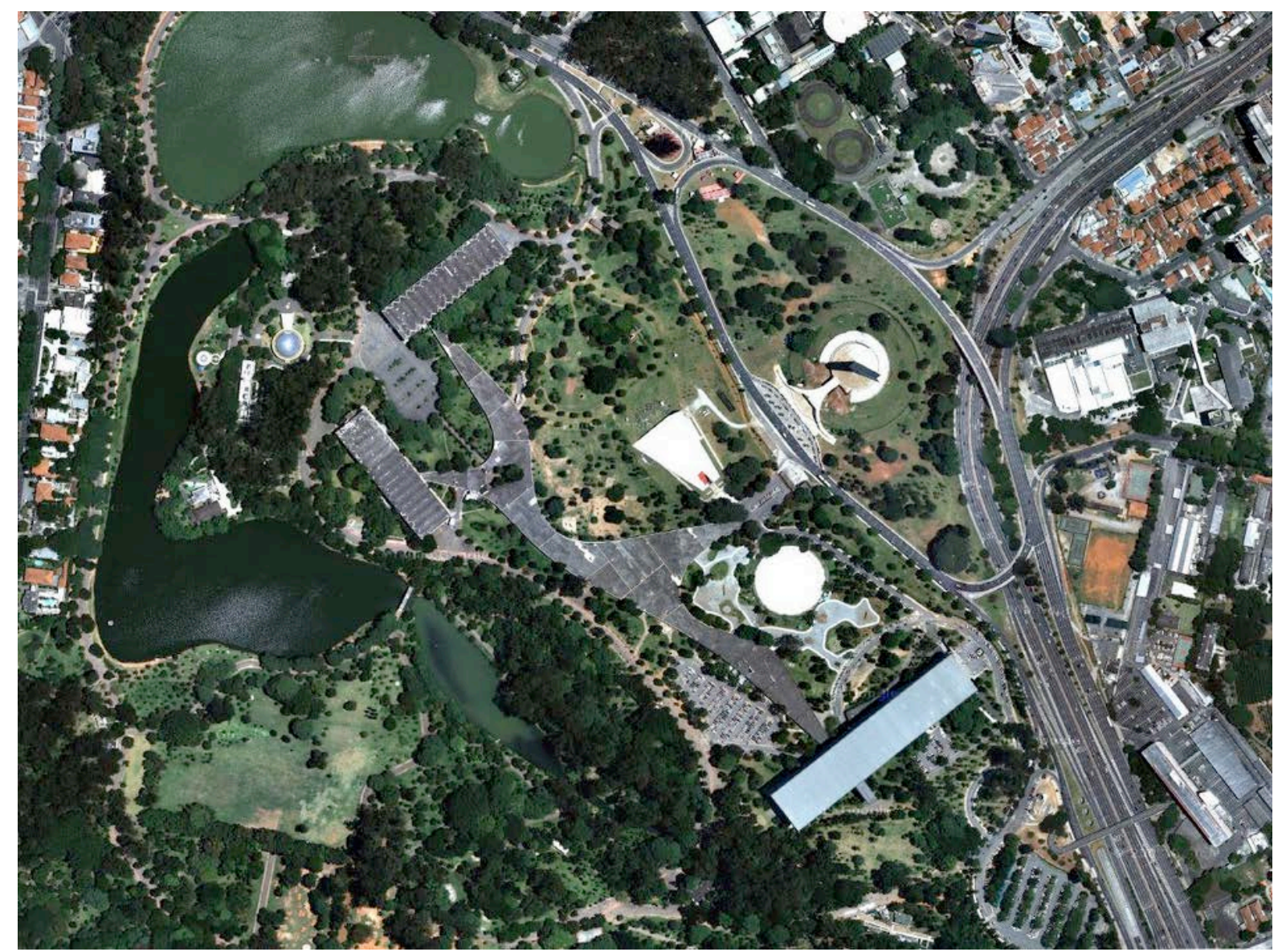

Oscar Niemeyer, Marquise do Parque do Ibirapuera, São Paulo (1954)

Se atentarmos à descrição de Guatelli para a Marquise do Ibirapuera, como um "espaço que é capaz de potencializar ações e acontecimentos inesperados", notamos que poderia muito bem estar descrevendo a condição específica de Copacabana, ou para este efeito, a descrição de qualquer praia urbana. Fica evidente na Marquise do Ibirapuera o gênio de Niemeyer, pois não se lança como um arquiteto que determina de forma controlada a experiência do espaço público. Niemeyer evita a redução da habitabilidade do espaço nos limites dos usos específicos, e muito mais nega a atitude do arquiteto formal que valoriza a imagem acima da própria experiência do espaço. Na Marquise do Ibirapuera Niemeyer cria um ambiente indeterminado e infinito em possibilidades, articulando uma visão infraestrutural da arquitetura, uma arquitetura de oportunidades que valoriza a experiência urbana acima de tudo, sintetizando aqui a capacidade da arquitetura como praia, uma praiapaisagem. 


\section{II_Condições \& dispositivos}

Como o Copan, a Marquise do Ibirapuera alcança a cidade através de suas extensões, de seus "galhos" que aumentam a capacidade de articulação do edifício para a paisagem, para a cidade. Discursando sobre a potencialidade de um urbanismo mais humanista e menos instrumental, a urbanista Regina Meyer sugere uma nova tática equivalente à imagem da árvore e seus galhos: “Ao invés de colocarmos uma mão fechada, deveríamos colocar uma mão aberta." ${ }^{166}$ A imagem oportuna sugerida por Meyer tenta estabelecer uma condição elementar para a ação urbana através do gesto de uma mão aberta, criticando tendências capitalistas que só veem na valorização dos objetos urbanos isolados a sua meta, sem ater-se às implicações do objeto do edifício na paisagem urbana e as suas múltiplas relações. A imagem da mão aberta alude à uma superfície complexa e múltipla em conexões. Comparativamente a imagem da mão aberta ou da árvore e seus galhos são aplicadas à Marquise e ao térreo do Copan. Qualquer palma de mão traz traços da história da pessoa acumulados às marcas do DNA, das impressões digitais, da cor da pele, da idade, indicando assim também uma complexidade formativa intrínseca às suas particularidades. Como a mão implica em uma superfície dupla, com um sobre e um sob, a mão aberta também pressupõe uma mão fechada (com um dentro e uma fora), ou vice-versa. A mão fechada indica mais um objeto (a imagem do soco, do punho fechado) do que uma condição (um abano, um adeus, dar a mão, etc.) A mão aberta, na sua qualidade indeterminada, tem os dedos apontados para além do seu próprio centro, indicando diferentes direções, como o rizoma deleuziano, que sugere uma extensão superficial ramificada em todos os sentidos. A mão aberta pressupõe um gesto generoso, uma dádiva, um convite, um aperto de mão, ou um movimento que tenta alcançar algo ("projeto" e "desenho" tem o mesmo sentido de "alcançar"). O "urbanismo mão aberta" articula-se de maneira similar: nega o objeto fechado, e abre-se assim em várias direções, buscando múltiplas conexões. Indeterminado, convida para algo que ainda não se sabe o que é. O urbanismo mão aberta é descentralizador e não olha para o próprio umbigo. No potencial do seu generoso gesto, olha para fora buscando o outro, convidando-o para entrar, como uma dádiva, para uma troca, para uma conversa, para um aperto de mão.

A superfície urbana vira assim elemento catalisador das dinâmicas entre os objetos urbanos, através da superfície estendida da cidade e seus atores, entendendo a superfície

\footnotetext{
${ }^{166}$ Comentário feito pela urbanista Regina Meyer em uma palestra na FAU Maranhão (maio de 2010).
} 
urbana não como um elemento à parte, separado dos outros, mas com uma continuidade em si e uma contiguidade entre outros, entre a arquitetura e a paisagem, entre as infraestruturas e a cidade, entre o edifício e a rua, como se, de fato, a interdependência entre todos é o que constitui verdadeiramente o espaço urbano e não as suas existências insulares, as suas exceções. É sempre na continuidade, na contiguidade dos elementos urbanos que experimentamos a cidade e seus espaços públicos. Perante a transformação rápida da cidade contemporânea, que enfrenta fenômenos tais como adensamento, fragmentação, abandono, compressão, e dilatação, a superfície surge como instrumento estruturador e organizador, negociando as partes distintas, como Michel de Certeau afirmou: "Este lugar, na sua superfície, parece uma colagem. Na realidade, a sua profundidade é onipresente. Uma acumulação de lugares heterogêneos."167

O deslocamento do olhar do objeto isolado e o enviesamento para a praia constitui uma estratégia paralela para problematizar a leitura crítica dos procedimentos do fazer arte, arquitetura e urbanismo. Para evitarmos aqui as armadilhas formais, abordamos pelo viés político e filosófico deste argumento orientando a narrativa pela epistemologia da superfície do quadro à cidade, passando principalmente pelo fenômeno da superfície em escultura. Esta identificação, dentro de um rigor que passa por referências claramente autobiográficas, aponta para uma nova possibilidade nas questões que vão de encontro aos grandes problemas enfrentados pelas nossas cidades e seus espaços urbanos, ${ }^{168}$ como se através da poesia possamos inexoravelmente encontrar novos rumos urbanos. Estas questões, colocadas nos interstícios da arte e arquitetura, abordam diretamente o problema do espaço, do espaço topológico e conceitual, do espaço tridimensional, do espaço físico, do espaço público, dos espaços das nossas cidades. O espaço da cidade é então considerado uma somatória de todas as complexidades espaciais, pois simultaneamente o espaço não pode ser isolado por categorias autônomas, mas sim compreendido como uma entidade em continuidade durável e eterna (o espaço que está aqui já estava aqui e sempre esteve), onde as fisicalidades conversam incessantemente com todas as consequentes dinâmicas. A cidade, com seus tecidos urbanos inchados e infraestruturas falíveis, sofre com os problemas crônicos gerados pela inadequação de uma arquitetura isolada. Fechada em seu próprio isolamento e obcecada pela aura do

\footnotetext{
${ }^{167}$ Michel de Certeau, "Spatial Practices: Walking in the City”. In The Practice of Everyday Life. Berkeley: University of Califórnia Press, 1984, pp. 91-110.

168 Rem Koolhaas afirma que "a cidade é tudo o que temos". Ver Rem Koolhaas, "What Ever Happened to Urbanism?" In OMA (with Bruce Mau), S,M,L,XL. New York: The Monicelli Press, 1995, pp. 959/971.
} 
edifício praiapaisagem propõe uma nova abertura do edifício para a cidade e da cidade para o edifício no esforço de encontrar outras direções em resposta à complexidade urbana contemporânea. ${ }^{169} \mathrm{O}$ redirecionamento do projeto intercepta procedimentos urbanísticos com as possibilidades da praia, levando assim a um novo esclarecimento da vocação do desenho dentro desta visão urbana renovadora.

Neste sentido, as manifestações em arte e arquitetura, se colocadas em diálogo direto com a problematização urbana, demonstram atitudes e viabilidades de praiapaisagem como conceito e estratégia. Estas práticas, não mais assumidas como processos finais de análise, mas inter-relacionadas às teorias, organizam as informações, a reflexão crítica, e as observações necessárias na articulação e construção de praiapaisagem. Neste encaminhamento situamos o fenômeno da praia em vários incrementos, apreendendo a sua complexa estrutura formativa através da abordagem crítica das condições espaciais fundamentais associadas à praia. Este processo revelou táticas de ação para um outro desenho do objeto e do urbano visando a constituição de espaços públicos pautados também pelos projetos-praia.

Duas vertentes se valeram como motivação central, formando uma dialética em relação à praiapaisagem: num mesmo momento em que um distanciamento geográfico e cultural da praias permitiu as aberturas à sua percepção ${ }^{170}$, uma necessidade premente de desviar os olhos do objeto surgiu para evitar um esvaziamento imediato com as proximidades que a questão apresentava - de tão próximos não conseguimos ver - fato este devido ao “inconsciente da praia” na experiência brasileira.

A praia é uma síntese, uma epítome do universo cultural brasileiro, qualificando-se como um espaço público triunfal, que alivia frequentemente a congestão urbana através de um indeterminado equilíbrio ambiental e social, injetando um enorme espírito positivo na psique brasileira. Tais fatores não se reservam às características ambientais dos sistemas ecológicos da praia, da faixa tropical, do acúmulo exorbitante do número delas no nosso litoral, mas principalmente nas maneiras que este tipo de lugar se assentou no espírito e na rotina das pessoas. A praia apresenta-se como infraestrutura urbana essencial em alguns casos, como vimos no bairro de Copacabana, articulando a transição das relações entre o homem e a natureza e entre os homens com eles mesmos, por apresentar-se como suporte

\footnotetext{
${ }^{169}$ Ver Pier Vitorio Aureli, “Toward the Archipelago: Defining the Political and the Formal in Architecture." New York: Log Journal 11, 2008, pp. 91-119.

${ }^{170} \mathrm{O}$ meu deslocamento ao Canadá e retornos repetitivos e constantes.
} 
para as relações sociais. Poderíamos então qualificar a praia como um modelo a informar estratégias de projeto para outros espaços públicos, ou mesmo a maneira de como desenhamos as nossas cidades. Mais que tudo as cidades são formadas por relações e suas respectivas redes (que consolidam as articulações). O território da praia, no seu estado imaterial, demonstra uma espacialidade de relações e a sua manifestação física evidencia a sua capacidade infraestrutural para servir mais como uma rede (network) do que como objeto urbano isolado.

A praia transforma-se em um estratagema para refletir sobre o território urbano, o local do encontro humano, o lugar em que habitamos a cidade, desvendando um outro desenho, a partir de um gesto aparentemente invisível que se dá intensa e cotidianamente na praia urbana. Nesta viva complexidade, vemos uma esperança humanística para a continuidade da construção dos espaços coletivos nos quais habitamos em harmonia com os grandes balanços ecológicos futuros. Ecologia aqui, como já afirmamos antes, não mais no sentido da preservação da natureza e dos seus recursos energéticos mas no sentido de casa, o sentido mais amplo de oikos: uma unidade entre homem e natureza. Praiapaisagem reconhece esta relação entre homem-natureza e propõe uma estratégia para a gerência dos recursos naturais pelo desenho, sugerindo assim a articulação de paisagens, edifícios e infraestruturas coexistindo como uma mesma entidade na extensão da superfície urbana. Este posicionamento holístico, sem separações, em relação ao desenho urbano e à habitação do homem encontra a sua gênese nas raízes nativas do aglomeramento humano através da oca Yanomami.

Como na oca dos Yanomamis, a praia às vezes ofusca as distinções entre a casa, o trabalho e o lazer, pois tudo se dá em uma mesma "arquitetura". A disposição formal da oca, oval, com as divisões dos grupos familiares em torno da sua periferia se voltando para o pátio central, orienta a vida para as trocas, para o espaço público, um terreiro comum. Este terreiro central é de uma flexibilidade enorme, pois recebe a produção, educação, rituais, manutenção, circulação, lazer, e encontro em uma única superfície, estruturada e protegida pela própria arquitetura do entorno. Poderíamos então, da mesma maneira, refletir sobre a ideia da praia enquanto casa, como extensão da casa, como a sala de visitas, e às vezes como o seu próprio quintal, uma extensão natural do universo doméstico. Por todas as suas características, consideramos o terreiro Yanomami como uma praiapaisagem, pelo foco que a visão urbana humanística de Mendes da Rocha sustenta: 


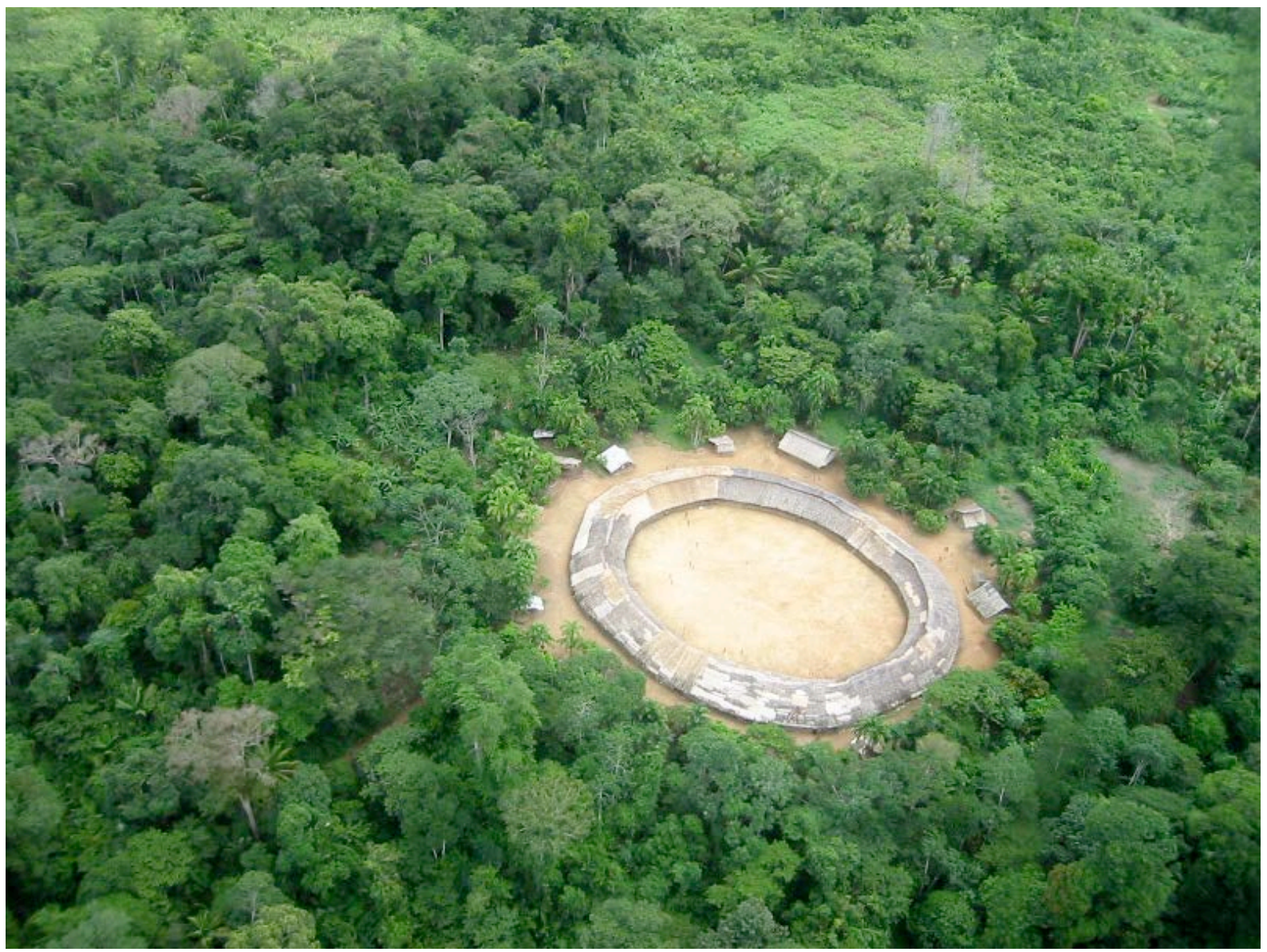

Praiapaisagem: a oca Yanomami

A técnica de construção da oca dos Yanomamis, feita com madeiras diferentes, quando se tenciona se deixa aquele vazio no meio. Precisamos parar um tempo aqui. Comer, conversar, combinar para fazer isso ou aquilo: vamos à fábrica ou vamos à caça... É interessante esse contínuo, mas que não é anacrônico. É um contínuo como se faz em música, contrapontos sempre: de vez em quando vamos lá para acertar aqui. Estes ideais sim, que evocam a questão da paz, da situação do mundo hoje, a partir da reflexão da arquitetura e da casa, é um raciocínio muito bonito... Não há outra cidade, a cidade que está aí é a cidade. Não há um desenho de uma cidade bucólica - a forma não garante. Como na literatura, no Ulisses de Joyce, ou na Odisséia de Homero, pode-se mudar a forma quanto se quiser, mas o discurso é aquele, como se se passasse na vida de um homem - alguns meses ou um dia. Outra coisa interessante é a separação de vida doméstica e trabalho. Nas casas primordiais, uma poética ainda hoje elogiada, é que elas eram também o lugar de trabalho, como na taba Yanomami. Era ali que se faziam os tecidos, as redes, os planos. ${ }^{171}$

Como na taba Yanomami, a praia aqui não é mais vista como a faixa litorânea de areia, mas como um território que organiza relações em rede. Consideramos que esta superfície maleável é algo intricado de mesurar ou de analisar segundo as convenções urbanísticas tradicionais. Tais procedimentos não fariam jus à sua própria complexidade. Como a taba, a

${ }^{171}$ Paulo Mendes da Rocha, “São Paulo: a New Geography”. Eduardo Aquino e Karen Shanski.

Complex Order: Intrusions in Public Space. Winnipeg: Plug In Editions, 2009, p. 136. 
praia não limita-se à uma condição visível e palpável, sujeita à quantificações, e portanto representável, mas sim evolve como um fenômeno múltiplo onde o físico, espacial, ambiental, cultural e social vivem integrados dentro de uma continuidade indeterminada e temporal. Tal como a análise crítica de um edifício como uma casa não se vincula simplesmente ao seu caráter construtivo mas passa também por constitutivos históricos e da própria experiência fenomenológica do habitar, a praia em si demanda uma outra compreensão crítica, o que atentamos aqui.

O fenômeno da praia como questão contemporânea expande as relações encontradas no conjunto urbano. Devido às complexidades identificadas liberamos e suspendemos a questão urbana do lugar, da constituição do lugar, para lançarmos a proposição de praiapaisagem. Este campo de argumentação estabelece que a condição contemporânea da cidade é regida pelas produções culturais influenciadoras das manifestações urbanas. Podemos aqui dizer que nem as especulações teóricas nem as observações de campo seriam suficientes para localizar o fenômeno da praia de forma sistemática. Então, através da observação das condições-praia e da catalogação dos seus dispositivos, renovamos a significação da praia para a cultura contemporânea, demonstrando a sua potencialidade para o desenho urbano.

\section{III_Procedimentos de desenho}

O olhar atento na condição da praia intenciona desconstruir a tradicional presença elementar no consciente coletivo, ampliando a sua compreensão dentro das disciplinas de arte e arquitetura. Para tanto a matriz entre praia / arte / arquitetura serve de base para a formatação de uma estratégia de abordagem da cidade e seus espaços públicos pelo desenho. Assim chegamos à identificação da superfície urbana como denominador comum entre a praia e o espaço público, a partir da superfície da escultura e dos seus processos. A apreensão de um novo entendimento da superfície urbana auxiliou um novo jogo de negociações dos "entres", promovendo uma continuidade pautada por qualidades espaciais e menos por rupturas abruptas, não constitutivas, onde campos de sociabilidade se multiplicam continuamente. Reiterando a necessidade de integração do objeto de arquitetura e da cidade a partir da referência da praia, reivindicamos um papel modificado para o desenho. Assim sendo, algumas estratégias podem ser propostas baseadas nas premissas descritas neste estudo, 
encontrando um novo papel estratégico para a superfície urbana. Praiapaisagem agora é proposta como um instrumento transformador dos espaços públicos.

Praiapaisagem aponta para uma série de procedimentos de desenho que indicam mais atitudes, posicionamentos, do que necessariamente técnicas. Podemos assim propor que o "desenho" assuma uma política dinâmica de ação urbana, pois compreendemos que a renovação urbana não se reduz simplesmente às tecnicalidades do desenho ou às tecnocracias das políticas burocráticas. Os projetos-praia comentados aqui são propostas que foram testadas pelo tempo, ou pelo seu desenho experimental, como Mendes da Rocha assegura: “não há um desenho de uma cidade bucólica - a forma não garante.” Então, o que estes projetos guardam em comum é exatamente uma outra atitude, um outro posicionamento perante o desenho, que carrega em si a coragem de vislumbrar uma nova vida urbana. Ao longo aos procedimentos de desenho, é o fator humano o protagonista na construção de uma forte identidade dos espaços públicos dinâmicos, e este caráter humano é sempre esquivo do projeto, pois depende sempre de condições muito além da própria manifestação física, técnica e pública destes espaços. De forma essencial, espaços públicos como Copacabana atingiram o seu sucesso devido à sua própria história e mitologia, segundo o seu próprio processo civilizatório, que revela-se além das qualidades físicas do lugar, por exemplo, através do consciente imaginado. Parte deste processo é a transição do desejo das gentes para os mecanismos políticos que garantem o compartilhar da cidade entre todos, agora dentro de uma cultura que cria um sentido de lugar coletivo e unânime.

Estes lugares não se apresentam exclusivamente como simples “áreas de lazer”, mas, muito além disso, são territórios de conquistas, de lutas, de celebração e de encontro, de uma procura incessante da identidade cultural coletiva que se expressa no espaço público e através dele. A praia de Copacabana é celebrada quando estamos nela e quando estamos fora dela. Esta identificação determinante de certos espaços públicos fundamenta-se principalmente no encontro do coletivo com a própria representação. É na interação entre as gentes onde este sentido é compartilhado, e havendo uma troca constante através do tempo a cultura é formada e a identidade confirmada. É na somatória entre estes processos culturais que a significação anatômica e formal do espaço público chega à sua potência maior. A partir da construção de praiapaisagem procuramos identificar algumas das qualidades primordiais da praia que agenciam a diversidade para os espaços públicos, articulados aqui por procedimentos de desenho que buscam nas suas potencialidades espaços urbanos mais 
identificados com o coletivo local, do que com as dinâmicas do capitalismo global. Os seguintes procedimentos de desenho assumem então um aspecto retrospectivo, reflexivo e proposicional ao mesmo tempo.

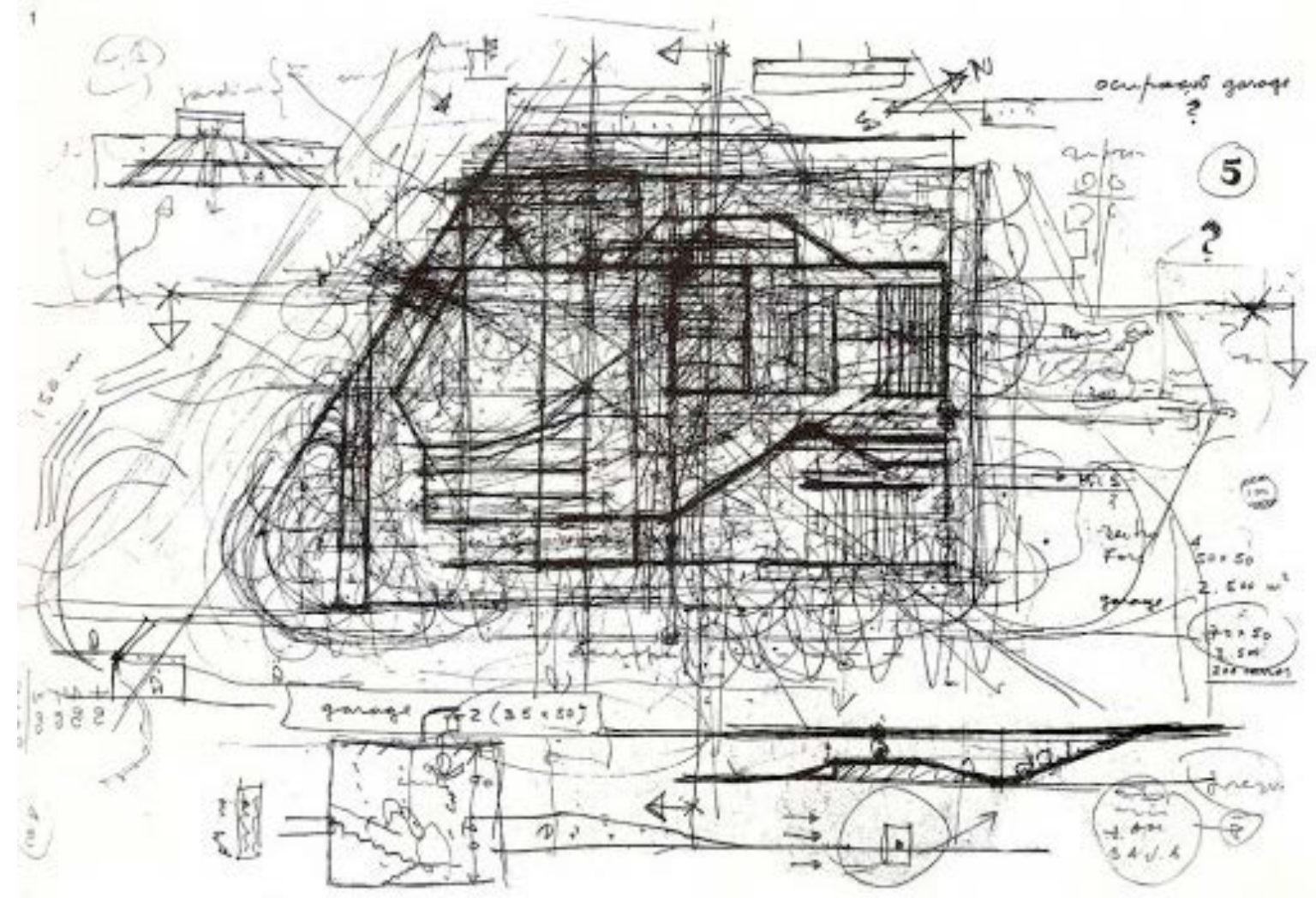

Paulo Mendes da Rocha, Museu Brasileiro de Escultura, São Paulo (1988) 


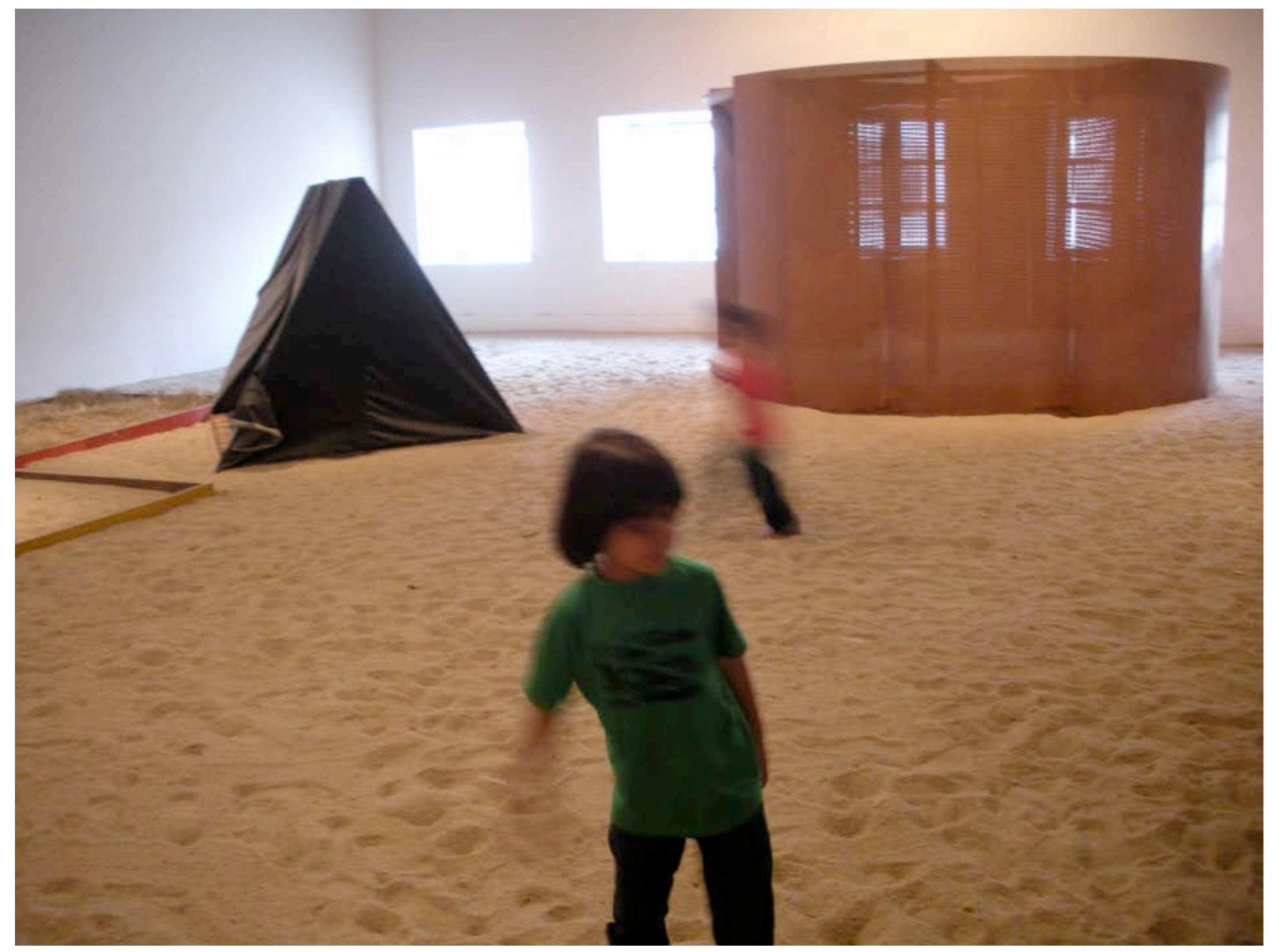

Hélio Oiticica, Éden-Tropicália, Centro Cultural Hélio Oiticica, Rio de Janeiro (2009)

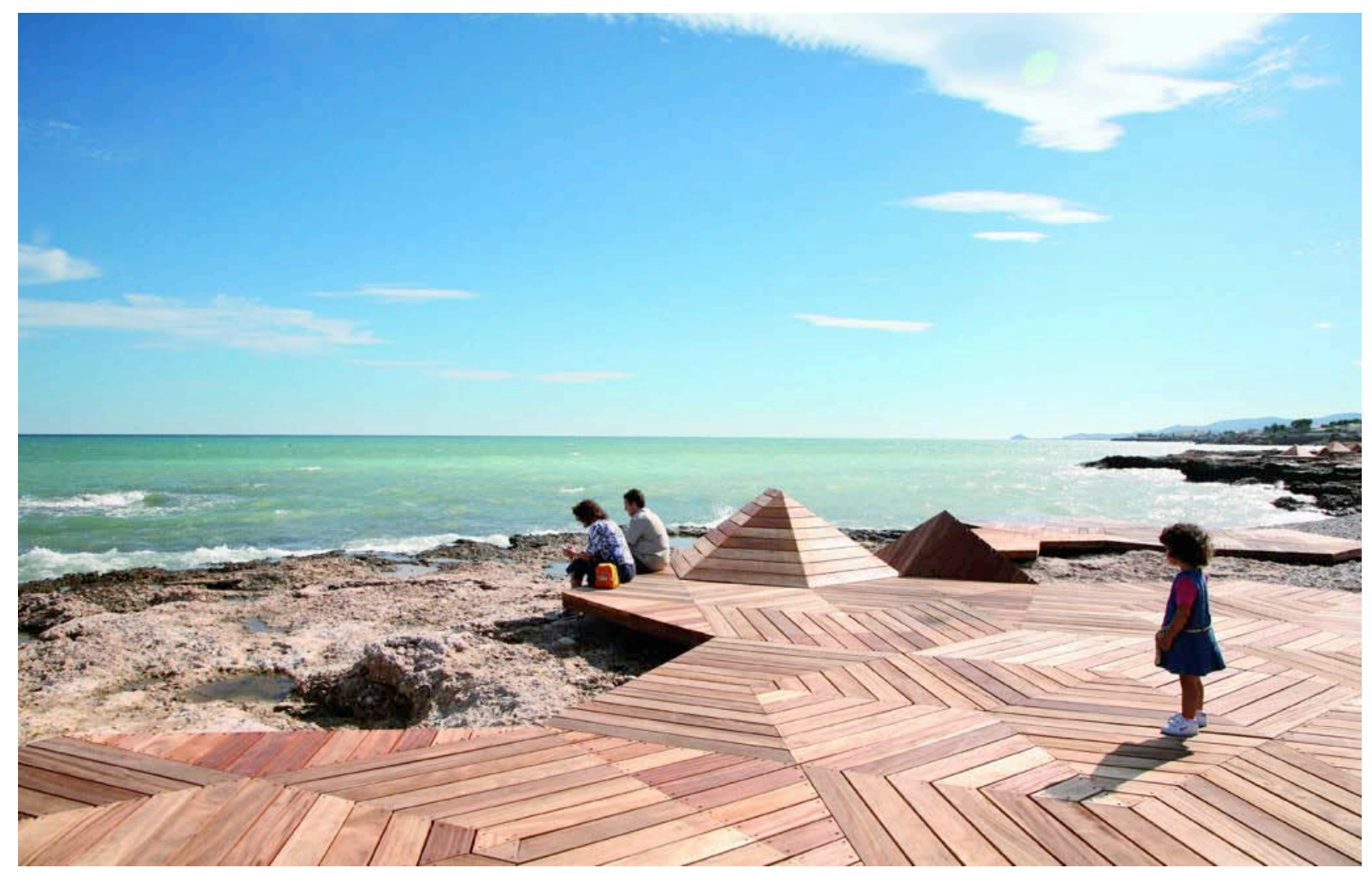

Vicente Guallart, Microcostas, Espanha (2006) 


\section{URBANISMO MÃO ABERTA}

O gesto da mão aberta pressupõe uma abertura do objeto de arquitetura em múltiplas direções, procurando um máximo coeficiente de conexões e relações com a cidade, através da permeabilidade da membrana, estabelecendo diferentes fluxos e contatos (Térreo do Copan). Estas múltiplas conexões podem se dar ao longo, acompanhando os objetos urbanos (Olympic Sculpture Park de Seattle, de Weiss \& Manfredi), ou atravessados, como na imagem da mão, perpendiculares à arquitetura, criando pontes e buscando a cidade para fora (Praça A19 Saint Adrià, em Barcelona). É possível também estabelecer as conexões nos dois sentidos simultaneamente, como na imagem de uma tecelagem. Na Praia de Copacabana, temos a predominância da linha estruturadora da Avenida Atlântica, mas temos que considerar como parte desta estrutura os "dedos" de todas as ruas transversais, pois estes criam acessos contínuos em múltiplos pontos. 


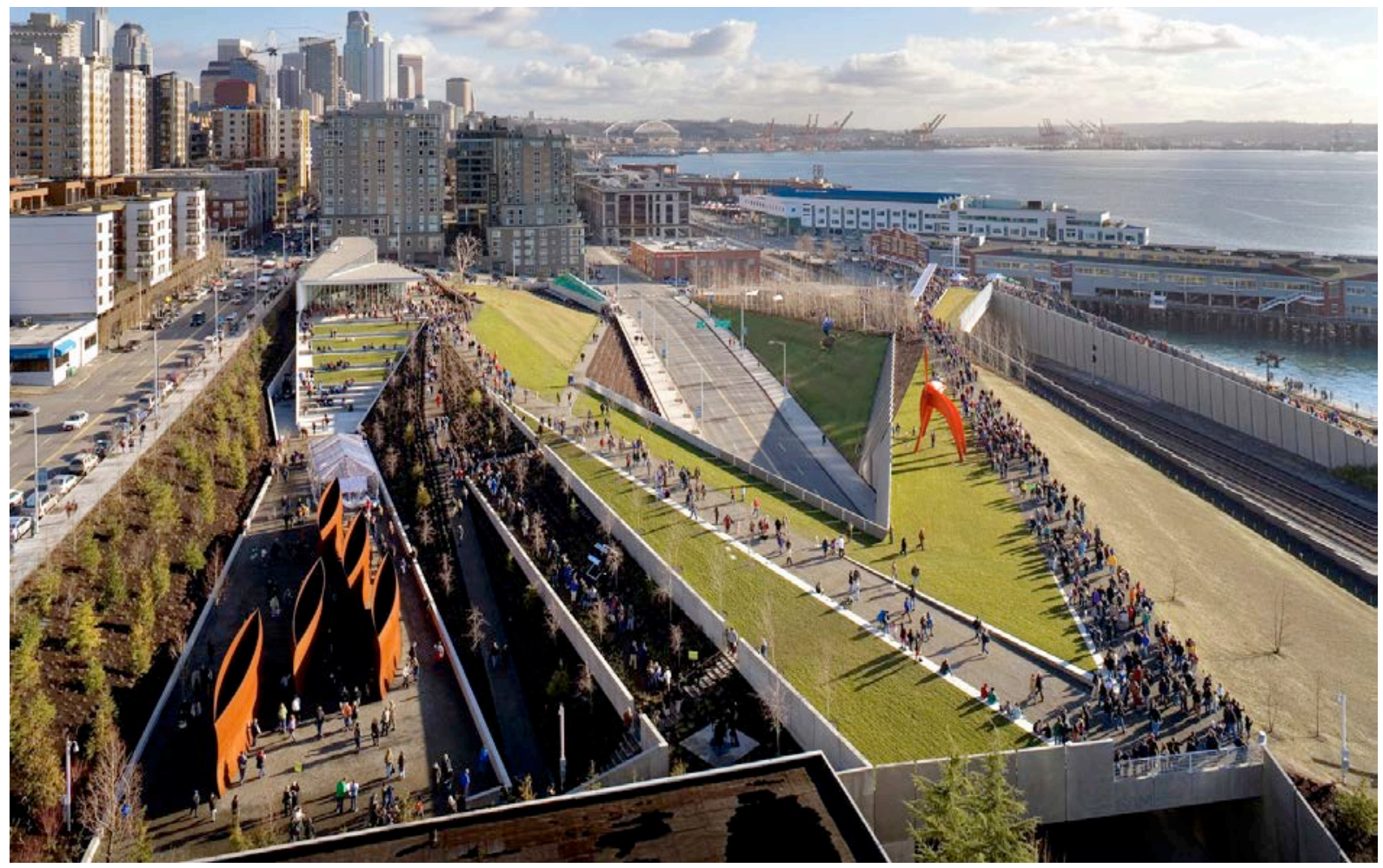

Urbanismo mão aberta: Olympic Sculpture Park de Seattle de Weiss \& Manfredi (2007)

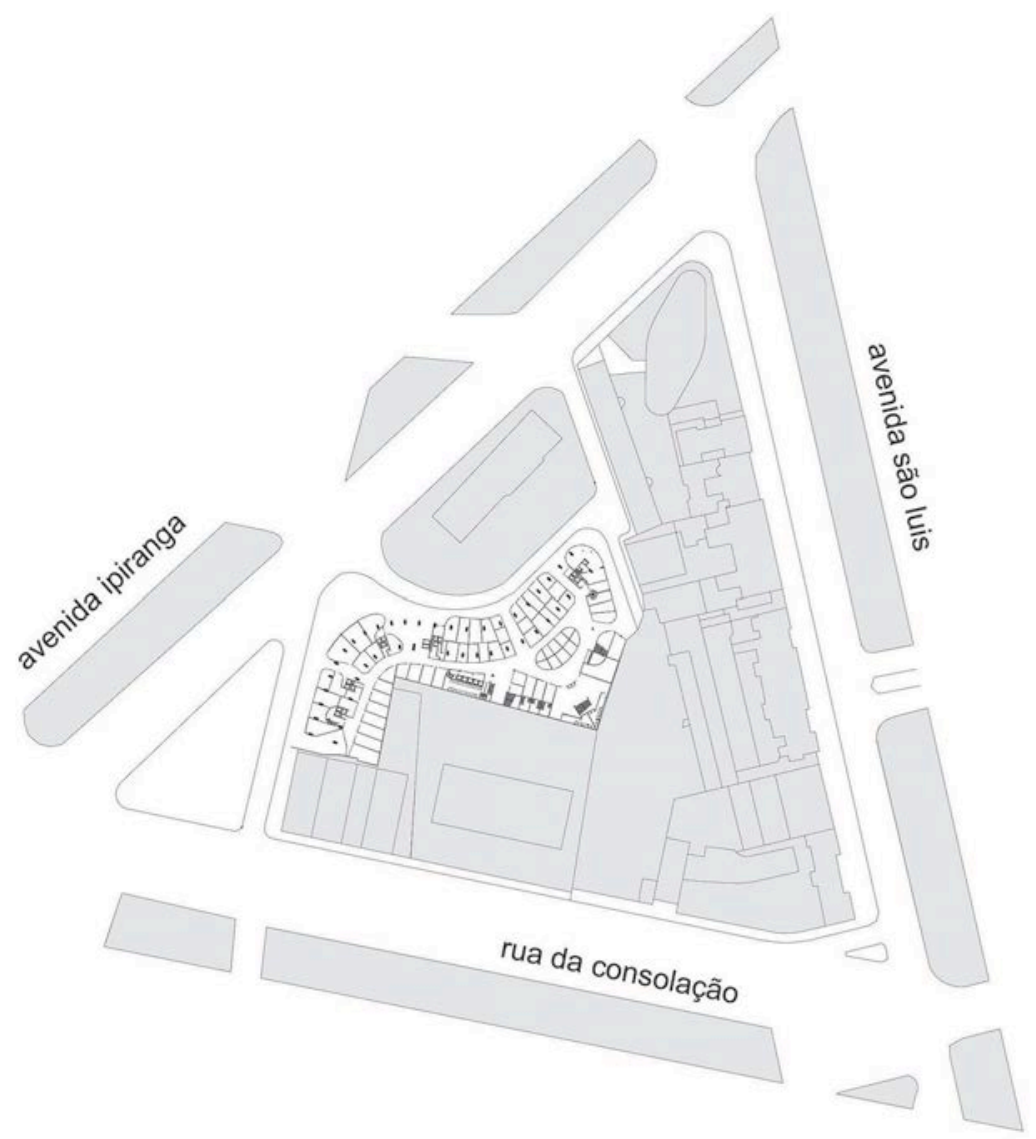

Oscar Niemeyer, Edifício Copan: implantação 


\title{
REINVENTAR O PROGRAMA
}

Se a questão da arquitetura ultrapassa valores formais ou puramente estéticos/tectônicos, resta então ao programa engendrar as novas dinâmicas do objeto (Seattle Central Library/OMA). Como consequência, o objeto da arquitetura vai incorporar as dinâmicas urbanas e negociar simultaneamente um urbanismo interno, trazendo a cidade para dentro do edifício (Galeria Pagé), e por um outro lado influenciar a cidade com a sua arquitetura urbana (Edifício Copan ou Conjunto Nacional). A abordagem crítica do programa representa agora uma nova oportunidade para os espaços públicos, especialmente pela sua multiplicidade de escolhas, como Amanda Lawrence e Ashley Schafer sugerem:

\begin{abstract}
Mais do que a simples aceitação de um programa fixo e passivo, alguém pode optar por definir os parâmetros fundamentais do que está a ser programado, reintroduzindo agência em arquitetura através do ato da programação. Tanto as possibilidades do programa se expandem quanto as oportunidades e variedades de operações para a sua aplicação arquitetônica, renovando a capacidade geradora do programa. 0 programa não é mais simplesmente colocado em prática, mas é o próprio agente ativo. Em suma, é requalificado a partir de um substantivo (uma entidade conhecida) para um verbo (uma ação latente com vários potenciais). Armados com uma oportunidade de programar, um grupo emergente de designers não se limitam ao programa convencional mas sim ao ato ativo de programar. ${ }^{172}$
\end{abstract}

Neste sentido o programa é multiplicado devido às qualidades conectivas e programáveis das suas superfícies, que permitem uma diversidade de ocupações constantes através das temporalidades específicas do espaço, apoiados agora pelas novas dinâmicas econômicas e culturais. Programar as superfícies subutilizadas (o Piscinão de Ramos); cruzar programas e superfícies, alcançando as espessuras e profundidades necessárias para fazer coexistir diferentes experiências urbanas (Parc de la Villette/OMA).

\footnotetext{
${ }^{172}$ Amanda Reeser Lawrence e Ashley Schafer, “Re: Programming”, Praxis (Journal of writing and building), número 8 . Cambridge, Mass.: Praxis, 2006, p. 5.
} 


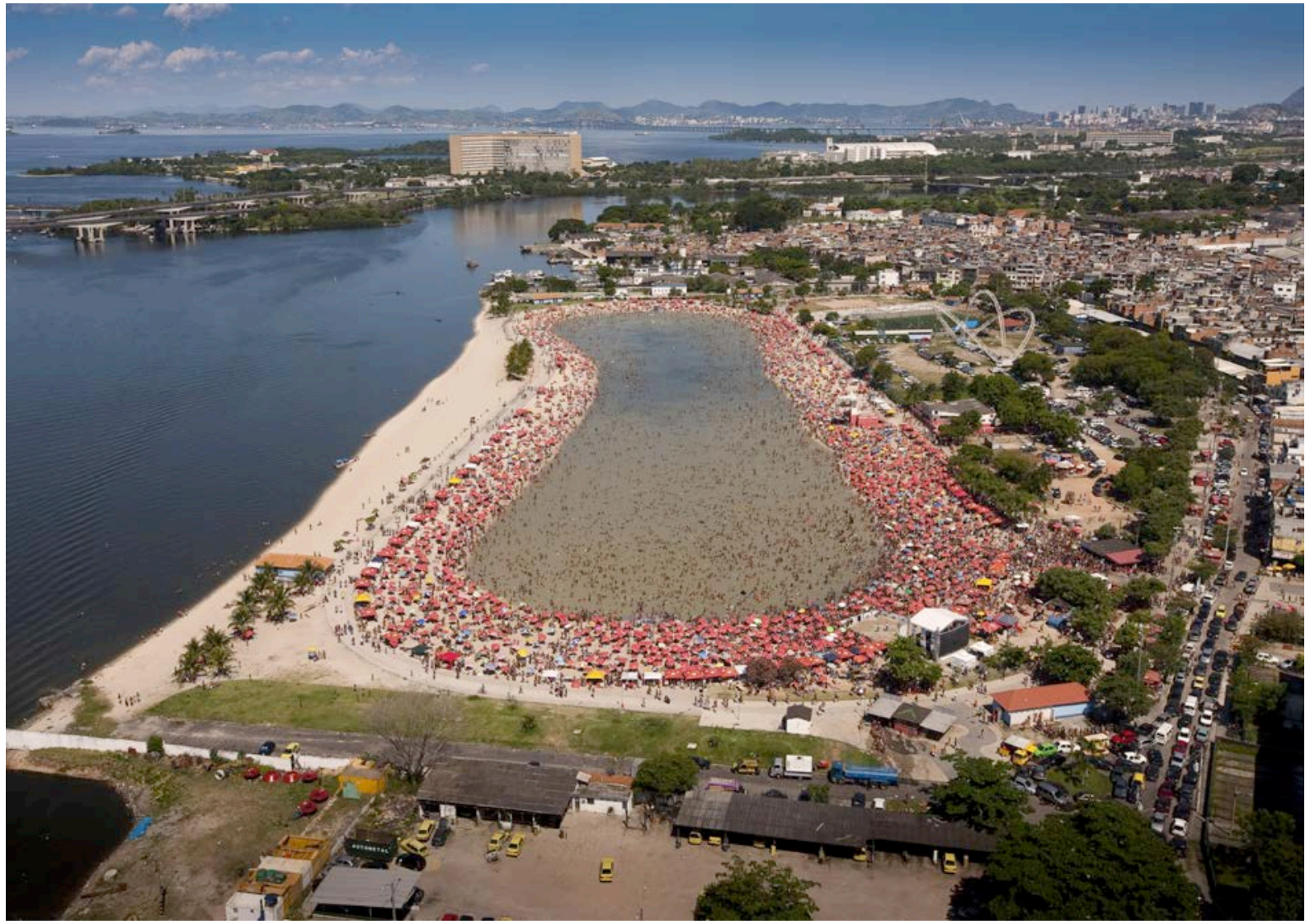

Piscinão de Ramos, Rio de Janeiro

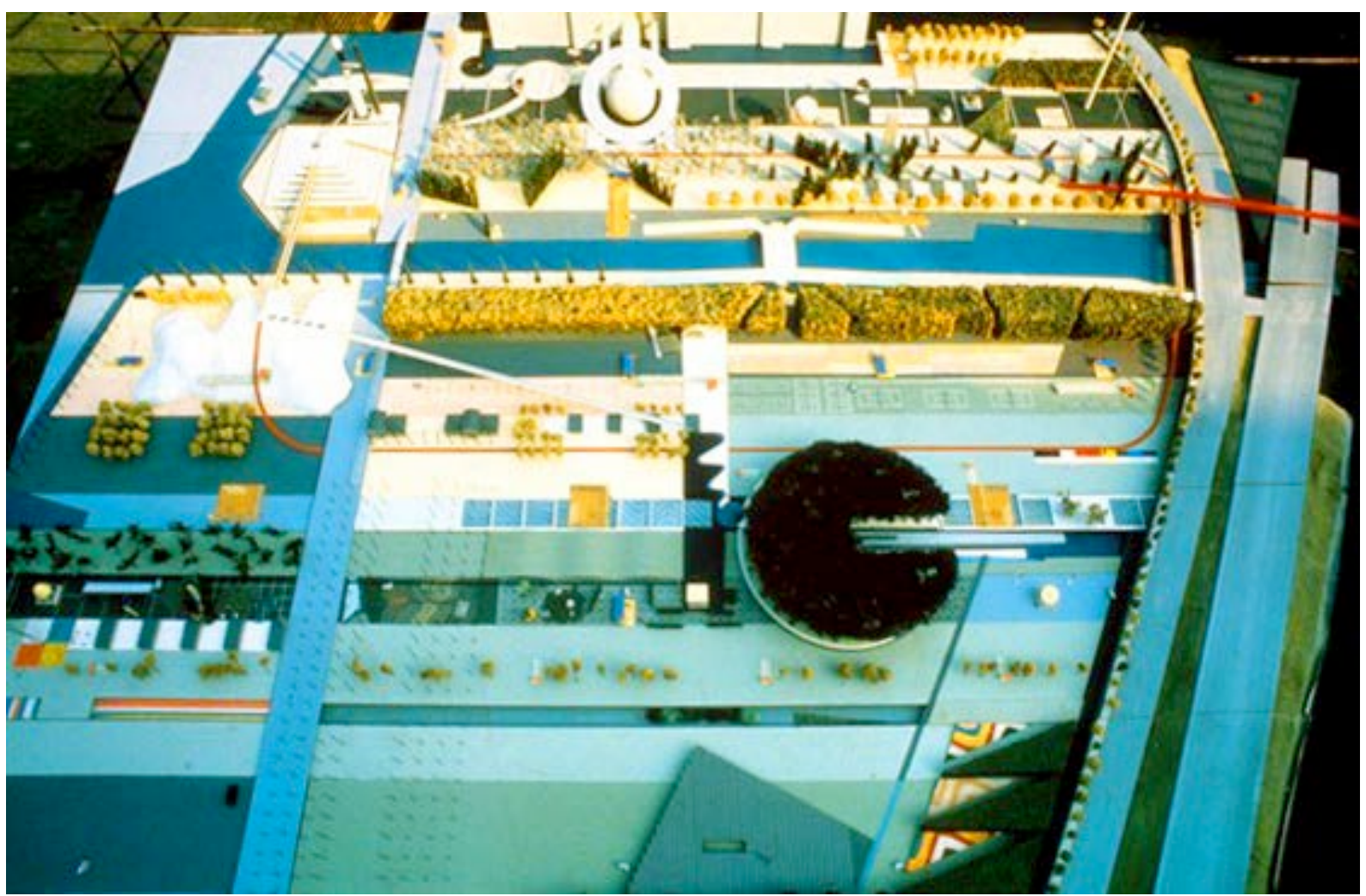

OMA/Rem Koolhaas, Parc la Villette, Paris (1982) 


\section{SUPERFÍCIE INDETERMINADA}

Superfícies sem programa sugerem num primeiro momento um vazio, ou até mesmo uma condição de terrain vague (a Feirinha da Madrugada do Pari). Temos que entender que na cidade não existem espaços vazios. O processo de sobreimposição de camadas urbanas através da história garantem a todos os espaços um significado particular, mesmo que na sua aparência se apresentem como "vazios". Ignasi de Solà-Morales elucidou este caráter urbano do vazio de maneira precisa:

A relação entre a ausência de uso, de atividade, e a sensação de liberdade, de expectativa, é fundamental para entender o potencial evocativo de terrains vagues da cidade. Vazio, ausência, mas também promessa, o espaço do possível, da expectativa. Hoje, a intervenção na cidade existente, nos seus espaços residuais, nos seus interstícios dobrados já não pode ser confortável ou eficaz na forma postulada pelo modelo eficiente da tradição iluminada do movimento moderno. Como a arquitetura pode agir no terrain vague, sem se tornar um instrumento agressivo do poder e da razão abstrata? Sem dúvida, através da atenção à continuidade: não a continuidade da cidade planejada, eficiente e legitimada, mas os fluxos, as energias, os ritmos estabelecidos pela passagem do tempo e à perda dos limites. ${ }^{173}$

Neste caso, a superfície da praia, a Marquise do Ibirapuera ou a Schouwburgplein de West8 em Roterdã ilustram claramente o pressuposto de Solà-Morales. O “indeterminado”, representado pela ausência de programas específicos, indica que o vazio urbano de fato tem vida. Um vida não baseada em predisposições, mas sim criada pela abertura de espaços, pela "perda dos limites", onde a experiência humana é produzida pelo imaginário dos seus ocupantes. A cidade é então inventada no tempo-agora, indeterminado, inesperado, imprevisível (Minhocão).

${ }^{173}$ Ignasi de Solà-Morales, “Terrain Vague”, Anyplace, New York: Any Publications, 1994, pp. 118-123. 


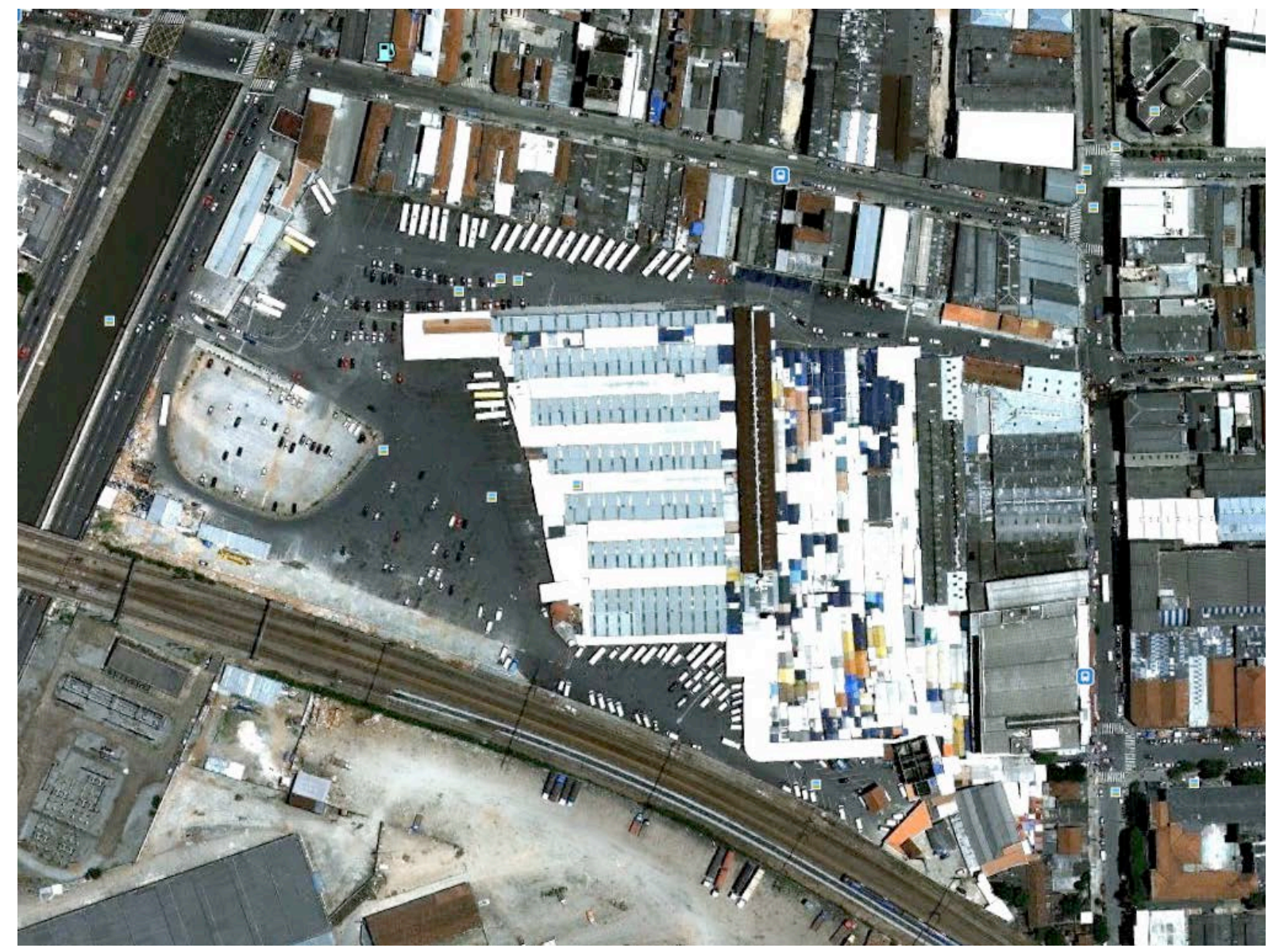

Feirinha do Pari, Brás, São Paulo

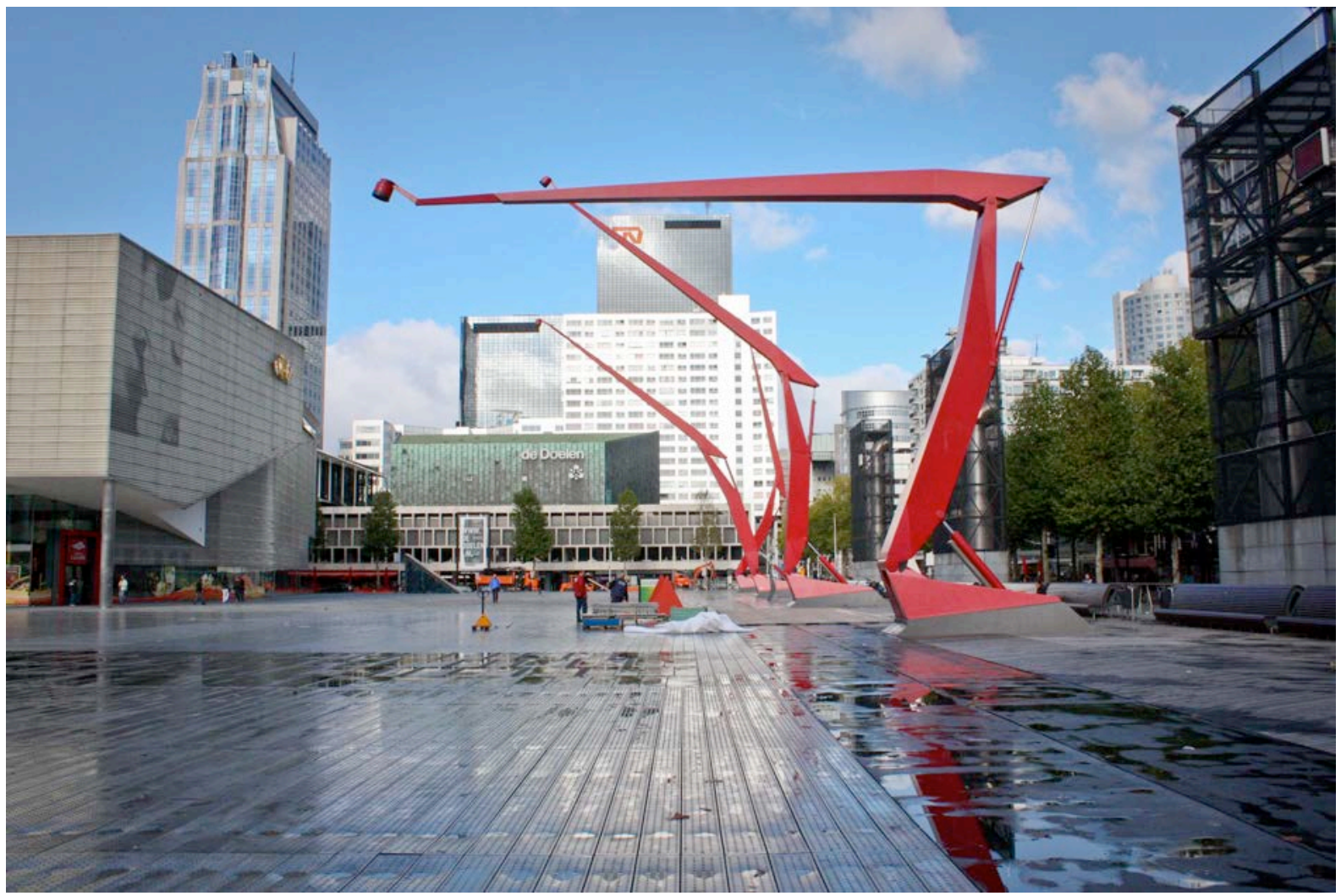

West8, Schouwburgplein, Roterdã (1996) 


\title{
OCUPAÇÃO GARANTIDA
}

\begin{abstract}
Você não pode mentir para uma praça, nem racionalizá-la. Desenhos e ilustrações persuasivas podem demonstrar imagens da vida em propostas para parques, jardins públicos ou espaços públicos, e racionalizações verbais pode convencer que usuários deverão apreciá-los, mas na vida real apenas ambientes diversos têm o poder prático de induzir um fluxo de vida e uso naturais e contínuos. ${ }^{174}$
\end{abstract}

Nem o programa, nem o objeto urbano garantem a ocupação do espaço da cidade. Teríamos que reconhecer os elementos perceptivos e fenomenológicos que influenciam a natureza dos espaços urbanos, incluindo as dinâmicas urbanas que dependem diretamente das qualidades temporais do espaço com seus distanciamentos e proximidades, aberturas, escalas, localizações e acessos. O que garante que um espaço urbano será ocupado? O tempo aqui é fator qualificador das experiências. O tempo também participa diretamente da experiência do lugar: tempo como duração, tempo como momento, tempo cronológico das histórias. E dentro do sentido temporal, as tecnologias: velocidade, iluminação, luz natural, inclinações, o sentar, o ficar, o passar, etc. São através das reações do desenho aos processos culturais e às respostas dos desejos coletivos de sociabilidade que se alcançam os resultados almejados. O desenho tem também o seu tempo. Resta ao desenho desenvolver estratégias de antecipação das dinâmicas sócio-culturais para assim evitarmos superfícies anacrônicas, como por exemplo a antiga Praça Roosevelt. Por outro lado, notamos o grande sucesso cultural urbano no Brasil: os bares de esquina. Neste sentido, a garantia de ocupação revela-se também para além do espaço urbano em questão, onde as suas características de tempo e vizinhança, a maneira em que as periferias do espaço público são programadas, também influenciam a sua intrínseca eficácia.

${ }^{174}$ Ver Jane Jacobs, The Death and Life of Great American Cities. New York: Knopf Doubleday, 1992. 


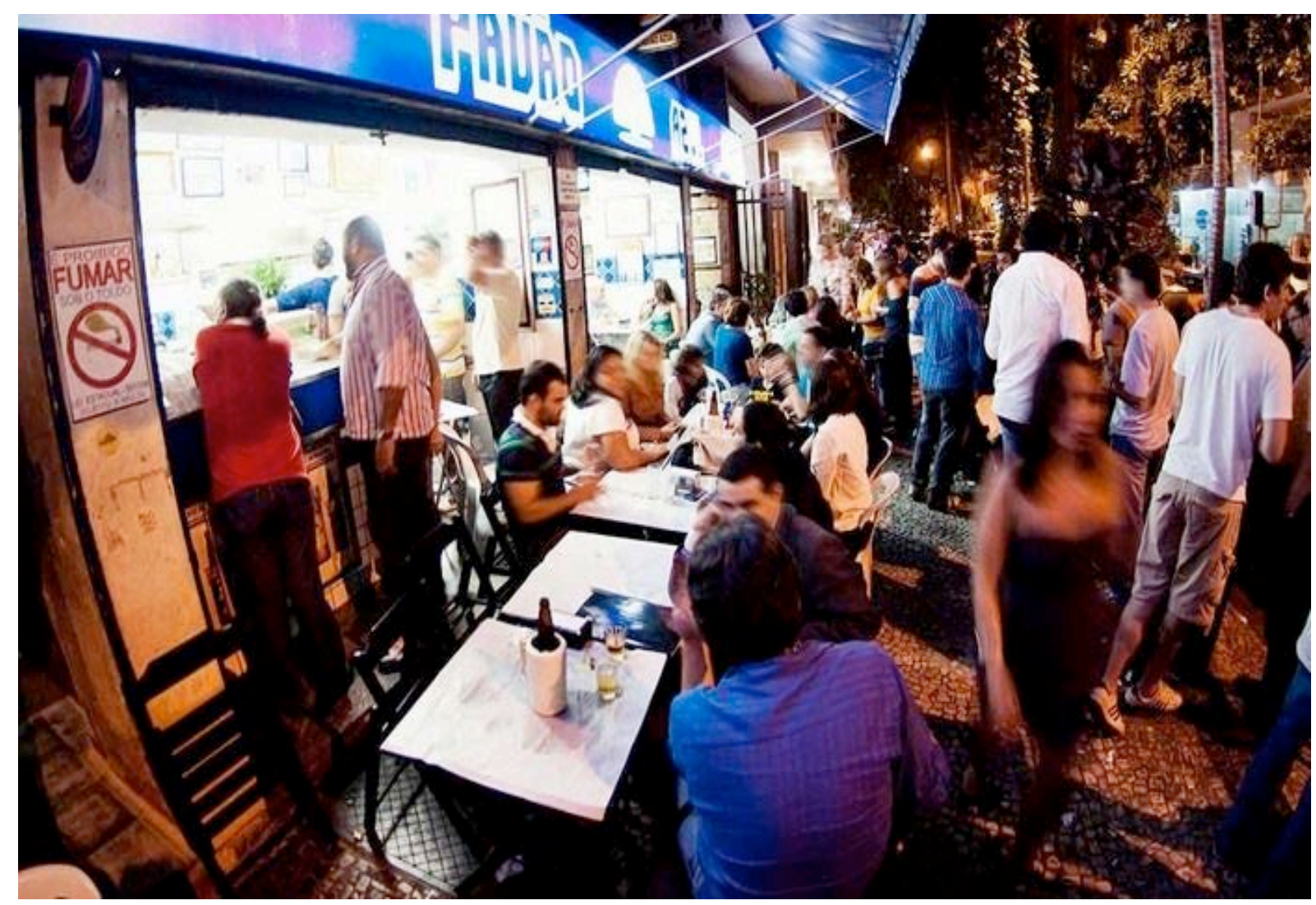

Bar Pavão Azul, Copacabana 


\section{SUPERFÍCIE AMPLIADA}

Dentro de um contexto urbano em contínuo crescimento a superfície urbana disponível torna-se cada vez mais rara. Entre os poderes burocráticos e as forças da economia global, a competição por estes espaços acirra, diminuindo no processo o livre acesso enquanto espaços públicos residuais. O que ocorre é que as potencialidades das superfícies urbanas existentes, ainda em um estado de terrain vague, não são facilmente identificadas. A aparição do Minhocão, por exemplo, deveu-se ao problema do barulho durante o período noturno e nos finais de semana. Com a proibição do tráfico de veículos nestes períodos, descobriu-se, acidentalmente, uma nova potencialidade para esta superfície urbana, transformando-a num espaço público de sucesso. Identificar as potencialidades de superfícies urbanas em um estado terrain vague (Minhocão) e ampliar as superfícies urbanas existentes (Copacabana de Burle Marx) é um procedimento de desenho eficaz no descobrimento de novos espaços públicos na metrópole congestionante. É na sutileza da organização estratégica dessas superfícies que vemos a possibilidade da garantia de uma boa experiência no solo urbano, bem como de arquiteturas interiores, onde a superfície urbana penetra as arquiteturas da cidade. 


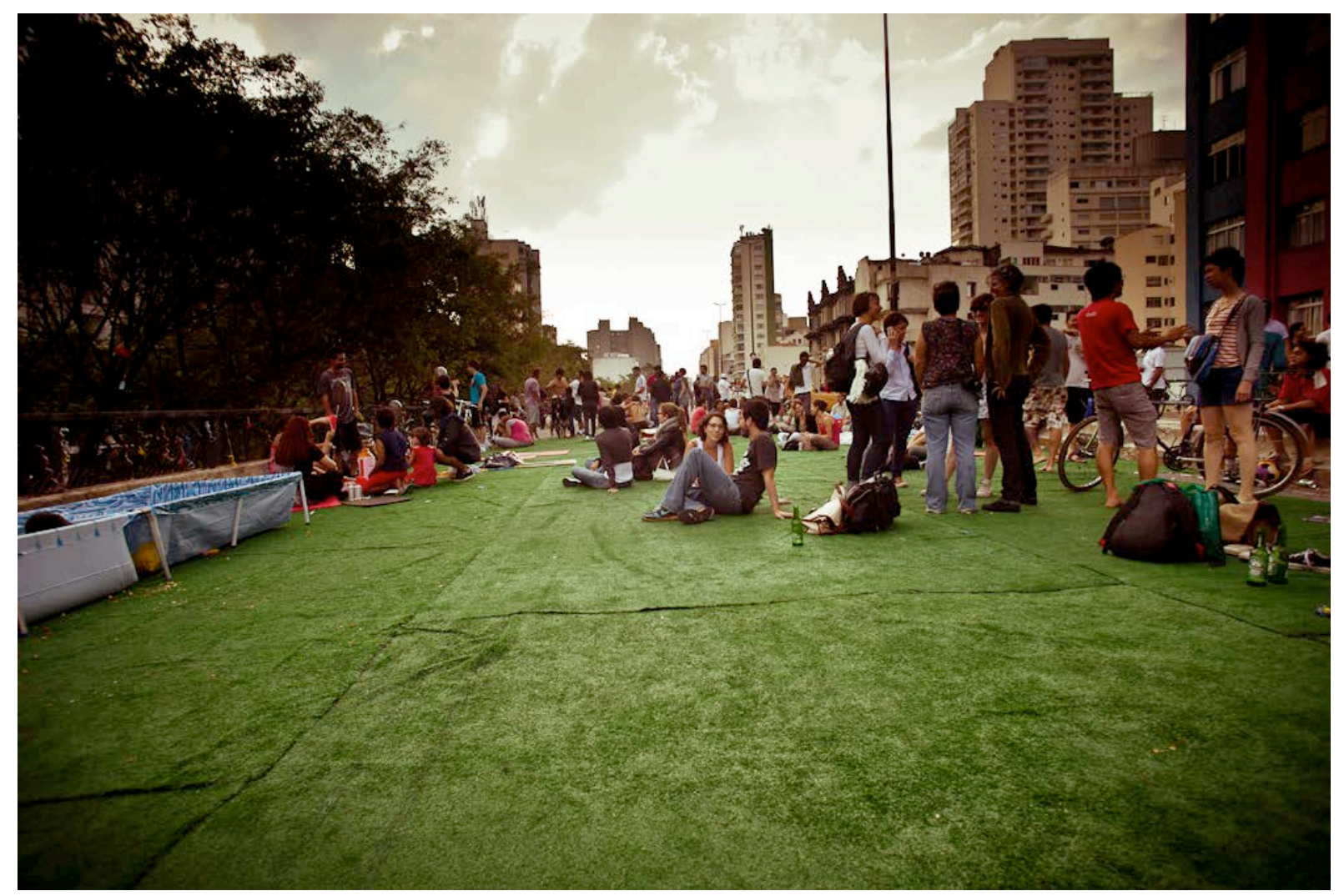

Minhocão, São Paulo

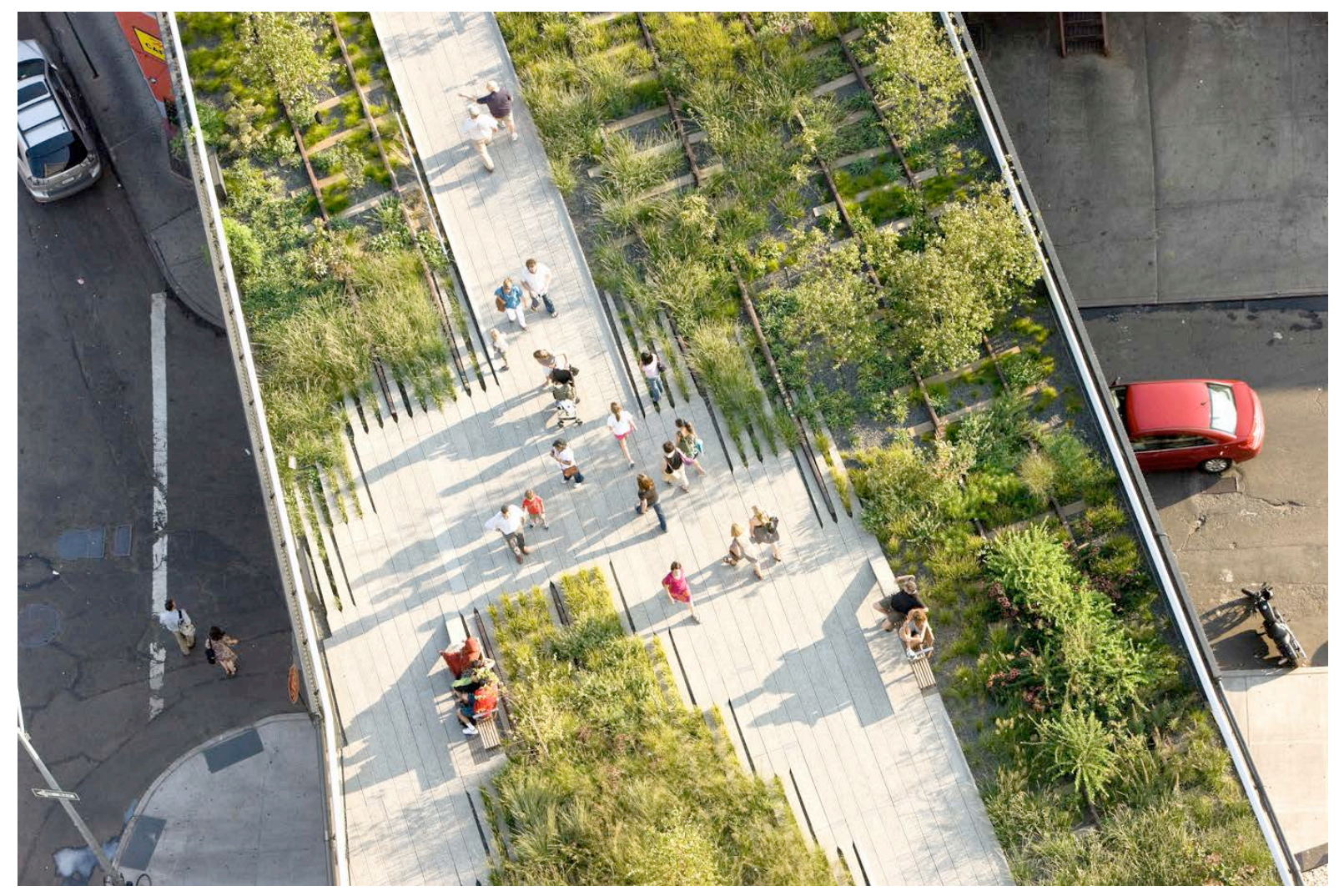

James Corner (Field Operations) e Diller Scofidio + Renfro, Highline, New York (2011) 


\section{SUPERFÍCIE INCLINADA}

Dos vários projetos-praia comentados aqui existe um agrupamento que carrega em si um aspecto em comum: a inclinação do plano, a inclinação da superfície urbana. São eles a Piazza Del Campo de Siena, o Sheep Meadow do Central Park, a Place Georges Pompidou em Paris, o Edifício Copan e a Grande Marquise do Parque Ibirapuera. Um plano inclinado no espaço público é análogo à presença do plano inclinado sempre presente na praia, indicando uma possibilidade efetiva quanto ao procedimento do desenho. Um plano inclinado propõe uma orientação específica para quem pausa no espaço, especialmente em relação à vistas. É mais confortável para se sentar e ficar. Existe uma outra qualidade de tempo quando circula-se num plano inclinado: subindo ou descendo, como mostra o sucesso da Marquise com os skatistas, por exemplo, ou o perambular dos consumidores na galeria do Copan: o tempo é mais acelerado ou mais lento. 


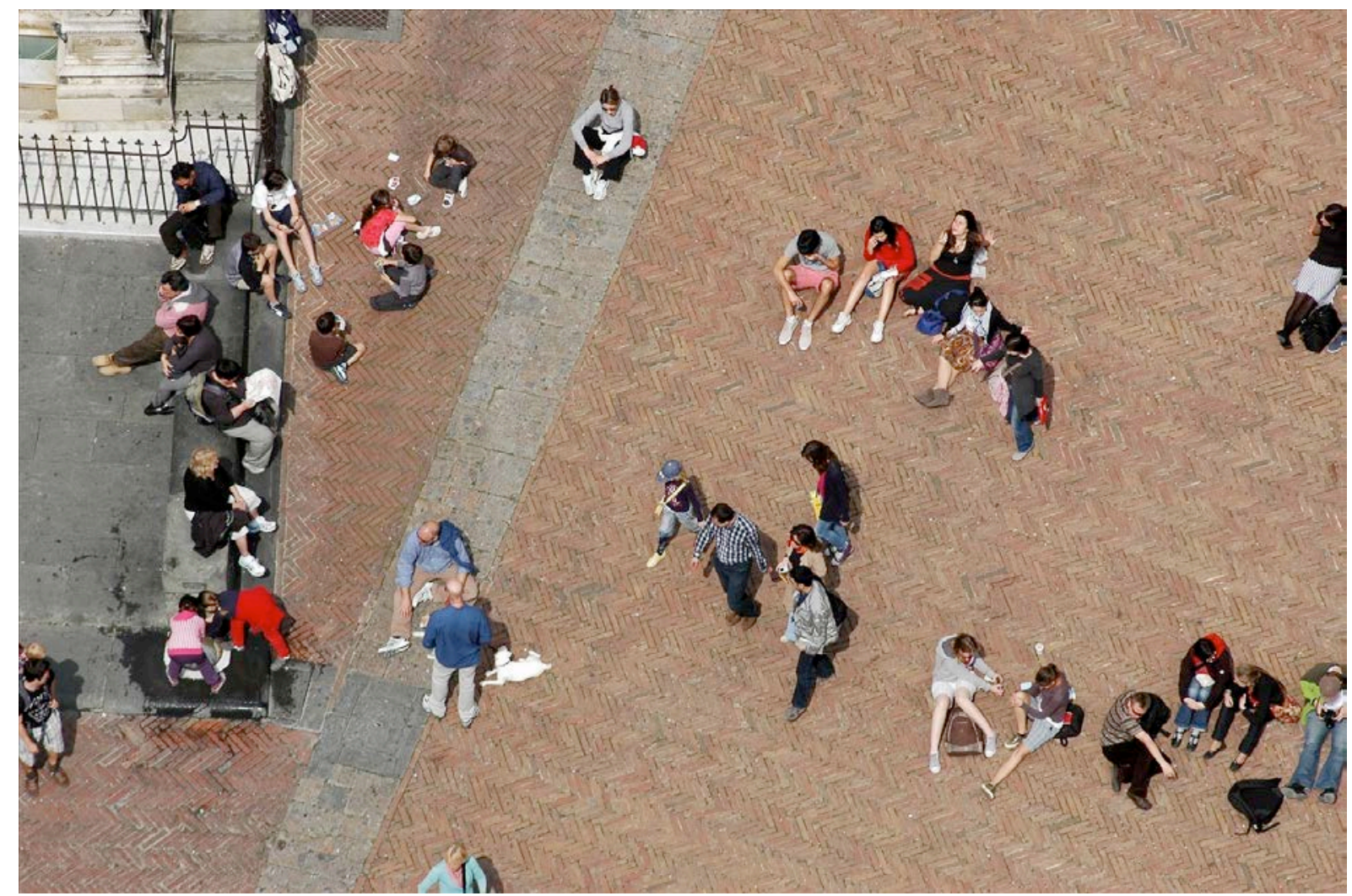

Superfície inclinada: Piazza Del Campo de Siena
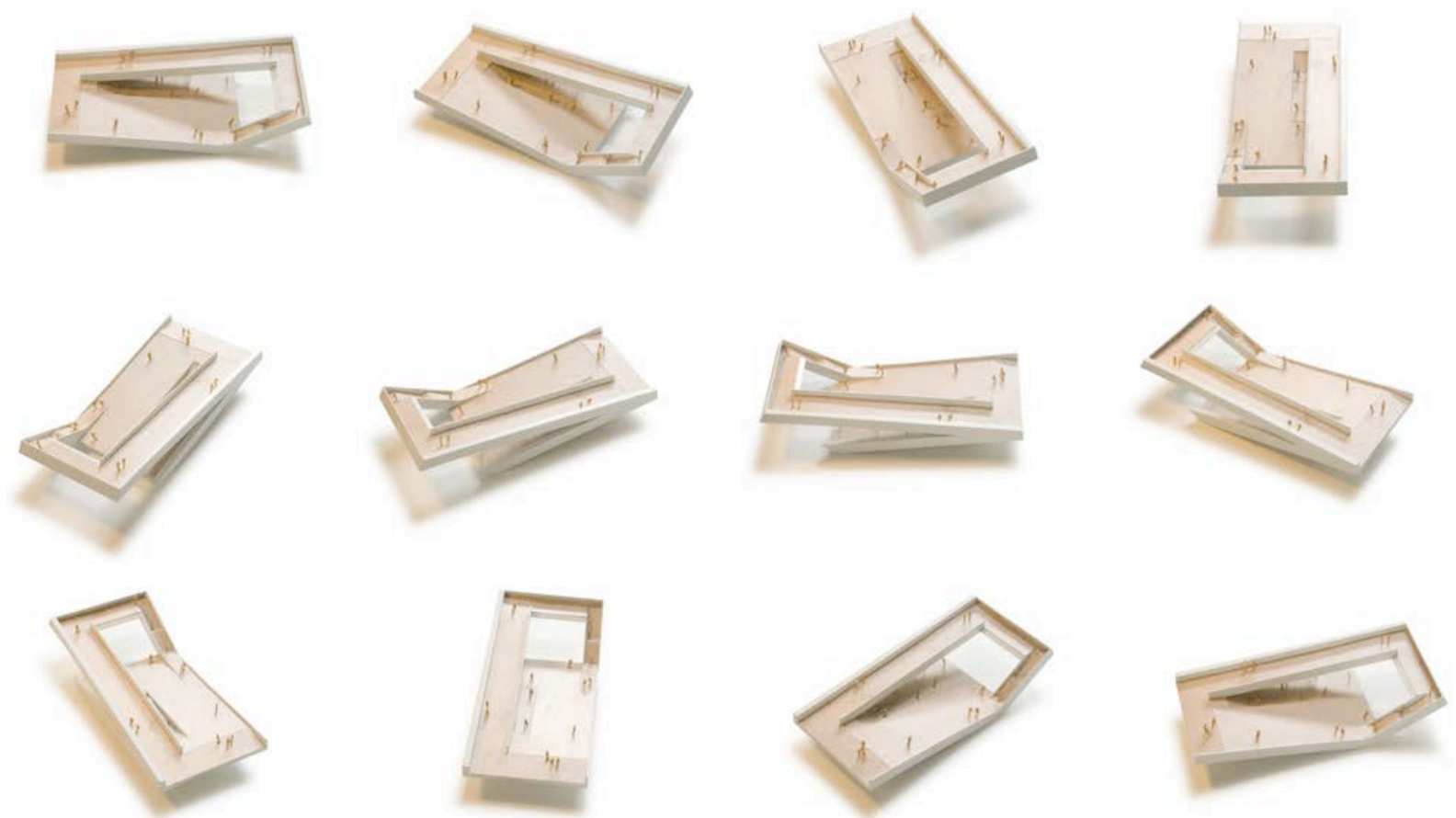

0+A, Estudo para uma praia urbana para o rio IJ em Amsterdã (2009) 


\section{MATERIALIDADES MALEÁVEIS, MATERIAIS FUTUROS}

A partir das observações da superfície de areia da praia ou da presença da água que ditam tanto o conforto como propõem uma lentidão de movimento, todos os materiais constitutivos de praiapaisagem são determinantes de qualidades específicas. Na tradição do Brasil urbano, o mosaico português ou o ladrilho hidráulico, por exemplo, representam materiais comuns, resistentes e versáteis, que correspondem a um equilíbrio entre o estético, o duradouro e o confortável, aumentando o potencial relacional entre o espaço e seu público. A gradação da gama total entre superfícies moles e superfícies duras com variadas combinações criam possibilidades estratégicas para a diferenciação de experiências relacionadas tanto à ergonomia do corpo e conforto ambiental quanto à velocidade da passagem do corpo pelo espaço até à sua permanência por períodos distintos. 


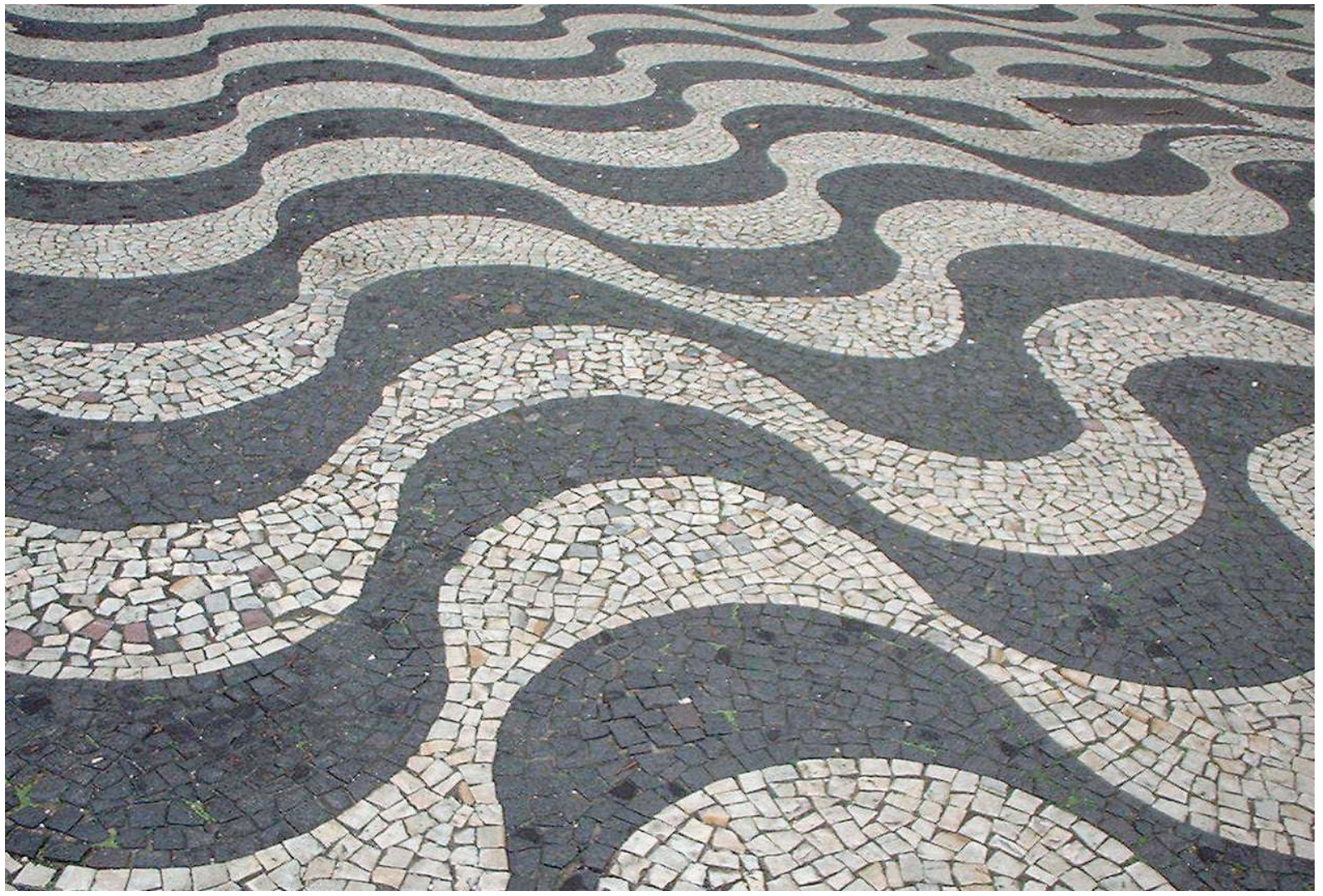

Calçadão de Copacabana

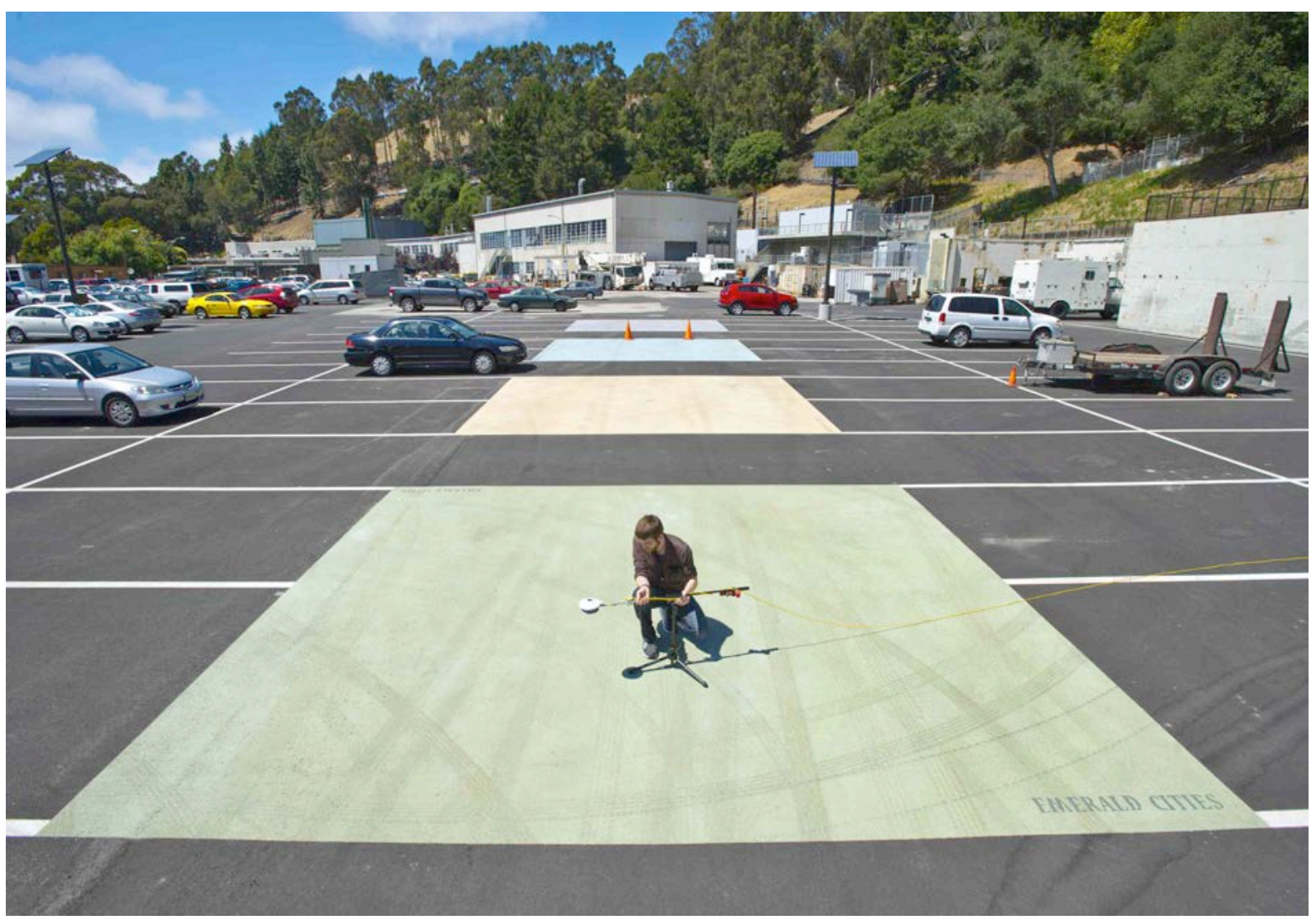

Jordan Woods do Berkeley Lab da Califórnia (Heat Island group) fazendo medições de um novo revestimento resfriado para pavimentos usando um albedômetro (http://heatisland.lbl.gov). 


\title{
O DESENHO DA SUPERFÍCIE
}

\begin{abstract}
Ao final dos anos sessenta, a experimentação informalista desenvolvida no ateliê de pintura [de Roberto Burle Marx] chega até seus jardins, principalmente no desenho dos pisos, recebendo a nomeação de jardim "Abstrato Lírico". Estes jardins estão compostos por superposições de camadas, de estruturas formais do cubismo, da idéia de construção da arte concreta e, acima de tudo, de uma gestualidade controlada, onde o gesto expressionista se manifesta, mas não transborda, configura mas não determina, desconstrói o rigor do traçado regulador mas não o elimina. Sua poética é resultado, não de eliminações, mas de soma. Seus desenhos são tomados por camadas e superposições, por uma geometria cheia de fraturas, deslocamentos e superposições de planos pictóricos e arquitetônicos. ${ }^{175}$
\end{abstract}

Um dos maiores ícones do espaço público brasileiro, o calçadão de Copacabana se prima pelo equilíbrio entre a tradição histórica e o legado moderno. A transformação sutil de Burle Marx de uma marca histórica catapultou o calçadão a ícone gráfico mundial. Este traço carrega em si a simbologia ideal do lugar (as ondas) registrando uma perfeita identidade com a praia. Além desta capacidade de marcar o lugar com um traço, o desenho do calçadão de Copacabana possui também uma capacidade fenomenológica pois "o andar sobre as ondas" organiza o ritmo e a direção do movimento da calcada além de promover uma sensação delicada de flutuação, de "estar sobre as ondas". O famoso exemplo do calçadão de Copacabana é indicativo da importância significativa do desenho da superfície: de como um padrão gráfico assume um papel fundamental na experiência e mitologia do espaço público, aspecto tão comumente reconhecido nas calcadas do Brasil e Portugal. Em uma escala urbana a tradição das superfícies da cidade tratadas com uma pavimentação articulada por uma qualidade gráfica rigorosa gera um espaço público com um maior potencial de identificação cultural.

\footnotetext{
${ }^{175}$ Cesar Floriano, "Passeio de Copacabana: uma referência da arte pública de Roberto Burle Marx", p. 7. Artigo apresentado no $8^{\circ}$ Seminário Docomomo Brasil (2009). Disponível em: <http://www.docomomo.org.br/seminario\%208\%20pdfs/159.pdf>. Acesso em: 11 de janeiro de 2014.
} 

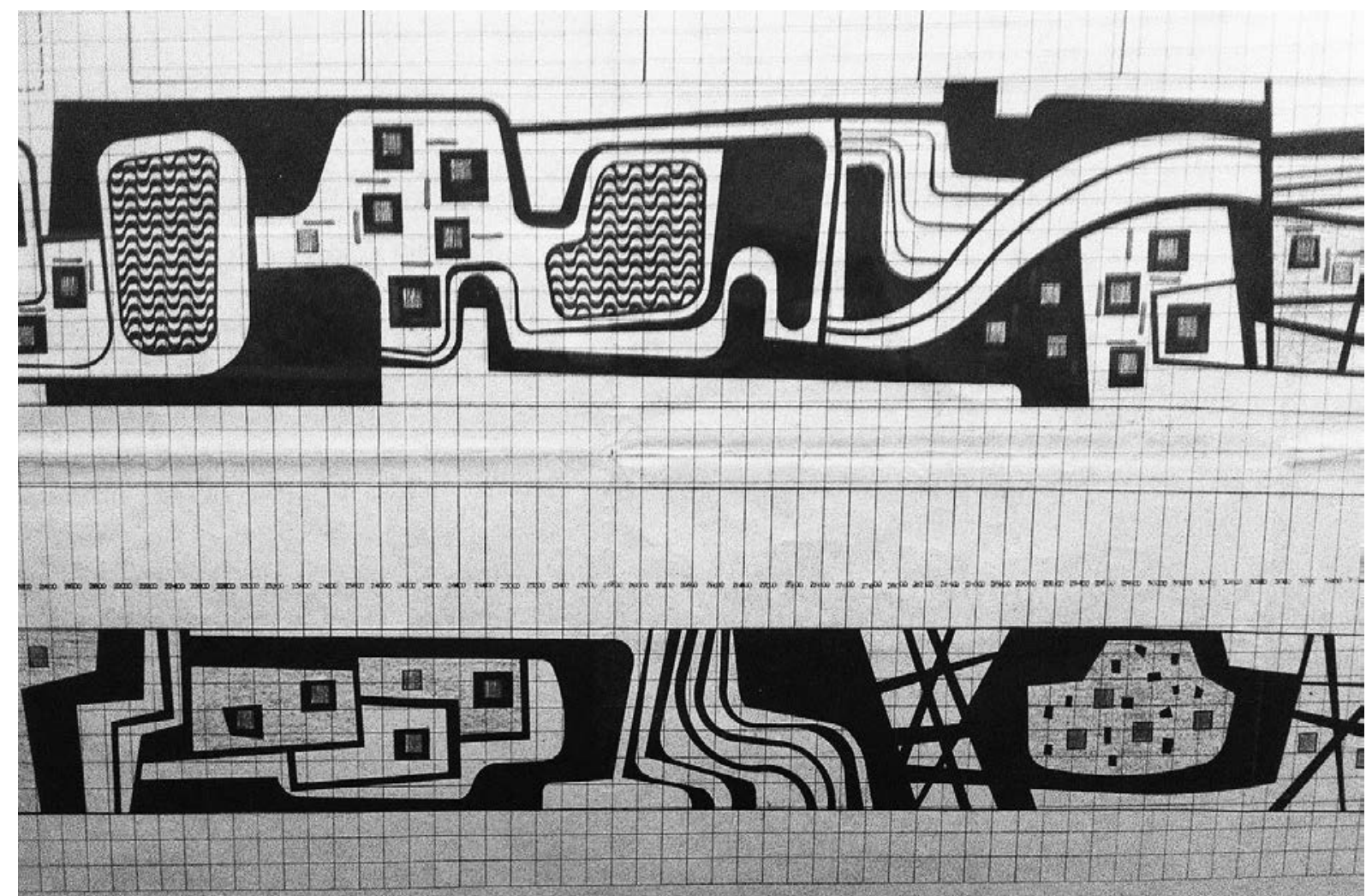

Roberto Burle Marx: Copacabana

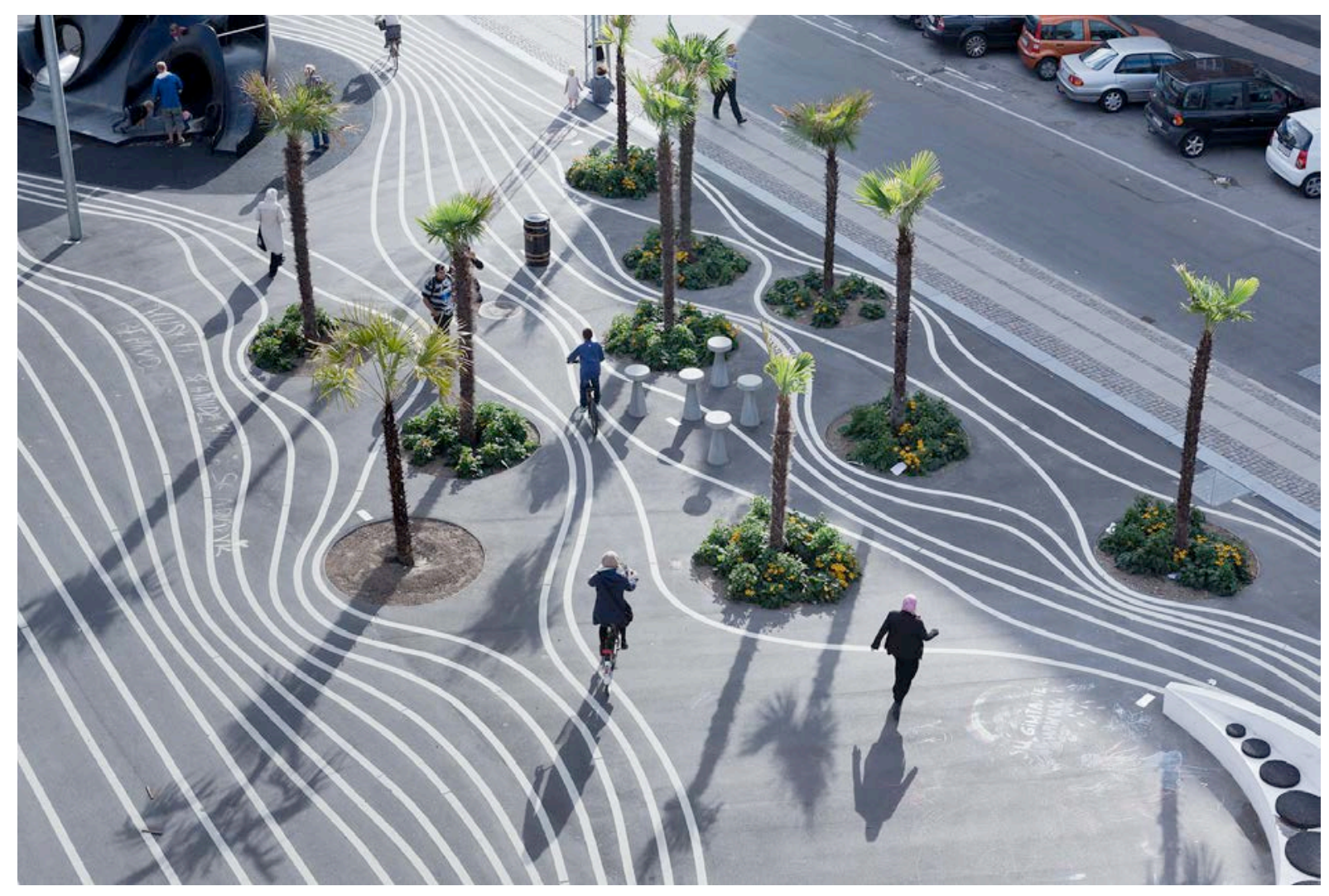

Superflex, Bjarke Ingels Group e Topotek1, Parque Superkilen, Copenhagen (2012) 


\title{
POETIZAR O URBANO
}

\begin{abstract}
A experiência estética é essencialmente final, isto é, o seu fim reside em considerar a situação de pertença de modo mais amplo, mais rico e intenso, fora dos mecanismos da rotina e sem recair numa nova habitualidade mecânica. (...) Poderia também ser a descoberta do paraíso terrestre, vivido na primeira infância, quando o impulso para o prazer dos sentidos não encontra repressões e censuras pela obrigação de prestar contas com as exigências práticas e sociais. ${ }^{176}$
\end{abstract}

Desde Charles Baudelaire, passando por Piet Mondrian, Marcel Duchamp, Vito Acconci, Hélio Oiticica, Francis Alÿs, os Situacionistas e muitos outros, ficou historicamente evidente que a prática poética do urbano sugere novas possibilidades de engajamento e participação na cidade. Tais práticas propõem uma nova leitura para os variados tipos de espaços urbanos, oferecendo alternativas de encontro, trocas e lazer, representando aqui uma transição entre as práticas poéticas e as políticas urbanísticas, como sugerida por Oiticica. As práticas poéticas deveriam então superar o seu caráter crítico insular, limitando-se ao próprio confinamento da produção artística, ao invés ativar uma disciplina híbrida entre o poético e o urbano. Seria assim um meio de envolver mais diretamente os poetas no desenho da cidade e os urbanistas no potencial poético do urbano.

${ }^{176}$ Renato Barilli. Curso de Estética. Lisboa: Editorial Estampa, 1994, p.34. 

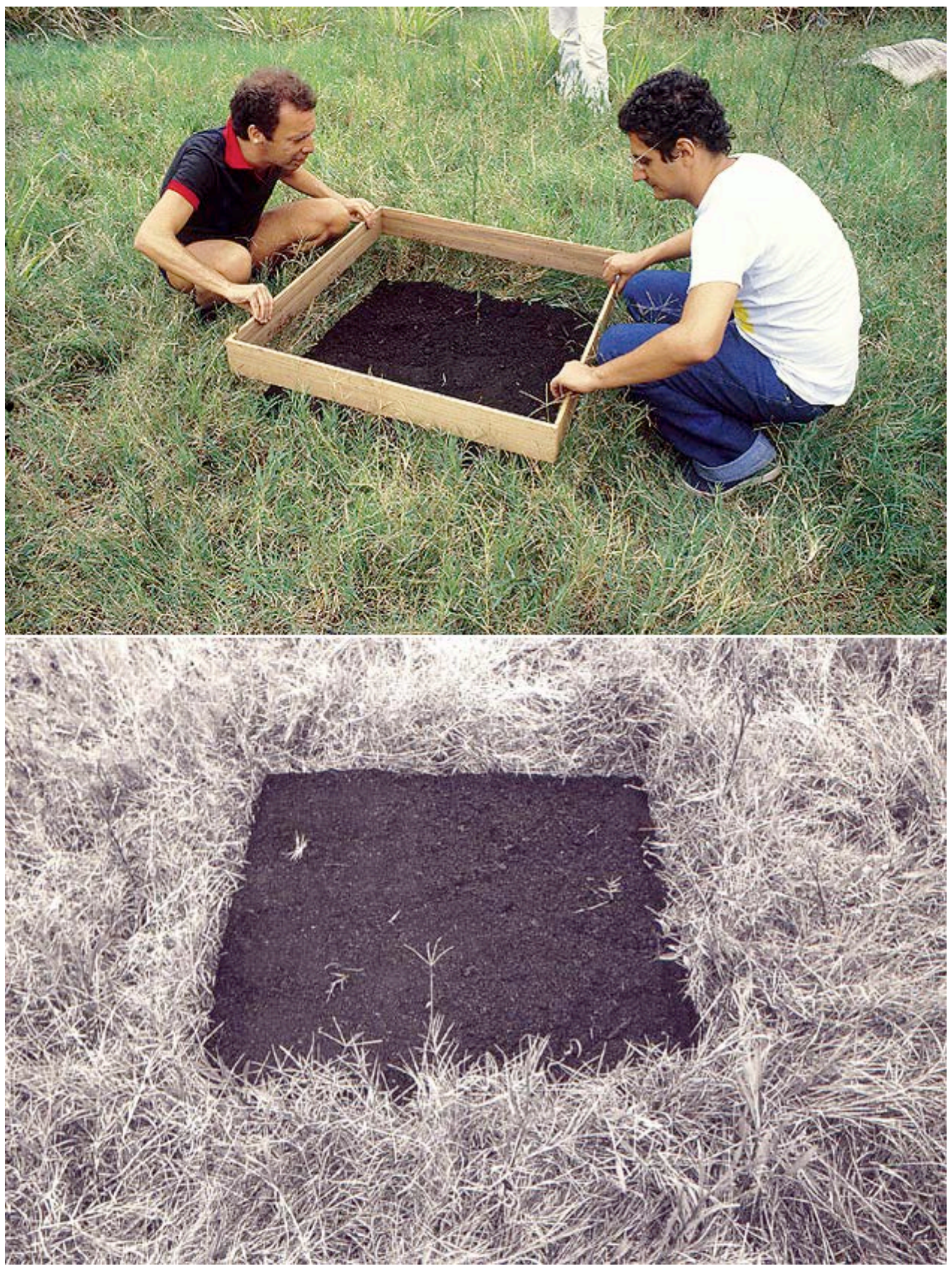

Helio Oiticica: Acontecimentos poético-urbanos, Contra-bólide devolver terra à terra, Caju, Rio de Janeiro (1980) 


\title{
ARTE PÚBLICA
}

O surgimento da arte pública como estratégia política nos últimos quarenta anos aponta para a potencialidade de transformação dos espaços públicos. Mesmo que na maioria das vezes as políticas municipais reduzem a obra em objeto de simples contemplação, quando consideramos o próprio espaço público como arte, na sua expansão e potencialidade plena, "a prática poética" em si propõe novas práticas e políticas a partir da arte pública. Mas antes precisamos redefinir a noção de público ${ }^{177}$ para que nos processos de articulação política a arte pública assuma um papel mais eficiente do que simplesmente criar controvérsia. Jane Rendell argumenta:

\begin{abstract}
O que significa para o espaço ser público? 0 espaço de uma cidade, construção, exposição, instituição ou obra de arte? Os limites projetados em torno de noções de público e privado não são linhas neutras ou descritivas, mas contornos que são culturalmente construídos, que mudam historicamente e denotam sistemas de valores específicos. Os termos aparecem como metáforas sociais e espaciais em geografia, antropologia e sociologia, como termos de propriedade privada na economia, e como esferas políticas em filosofia política e direito. Público e privado e as variações entre esses dois termos significam coisas diferentes para pessoas diferentes - isolamento protegido ou de contenção indesejável, intrusão ou convite, exclusão ou segregação. E como a privatização do espaço público ocorre cada vez mais em todas as direções - estendendo-se para fora, para todas as regiões do globo e para dentro, para alcances escondidos da mente - é preciso definir cuidadosamente a forma como usamos os termos.
\end{abstract}

A arte pública tem a capacidade de traduzir a riqueza da vida urbana e transformar o espaço público em algo de significativo e simbólico. A tarefa não é fácil haja visto as dificuldades enormes de articular representações localizadas. As políticas municipais são insuficientes para responder a tal complexidade. Mesmo assim a arte pública apresenta a possibilidade de ampliar o repertorio de praiapaisagem através de obras permanentes de cunho site-specific, ou efêmeras através de performances ou instalações temporárias, criando assim uma arte localizada, identificada com os outros atores do espaço público. Adicionando ao repertorio tradicional da arte pública Saskia Sassem sugere também que "as novas tecnologias de rede abrem e ampliam a questão de como construir espaços modestos e com a participação das pessoas. Uma questão que pode servir para captar soluções críticas pode ser:

\footnotetext{
${ }^{177}$ Não podemos esquecer aqui a noção de espaço compartilhado ao invés de espaço público, como propõe Temporary Services.
} 
Como é que vamos urbanizar o código aberto (open-source)?" ${ }^{178}$ No processo de redesenhar o espaço público a arte pública vem de encontro com a necessidade de superar as imposições do capital que dissolvem a escala humana do lugar. A prática do desenho produz narrativas que contribuem para o valor dos contextos existentes, produzindo também uma espécie de arte pública que pode produzir narrativas de ruptura ao capital globalizante, tornando legível a cultura local silenciada.

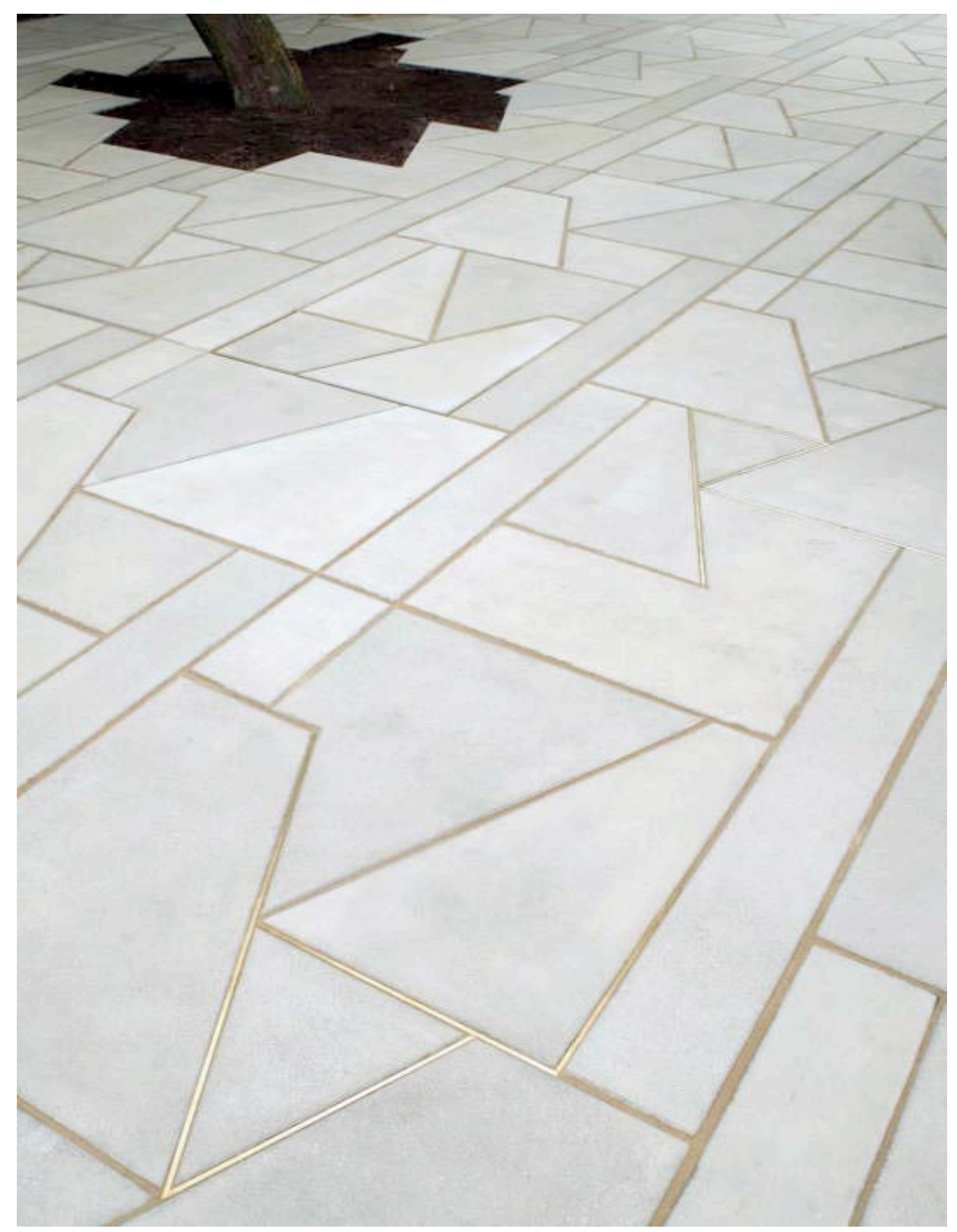

Martin Boyce, We are Still and Reflective, Münster (2007)

${ }^{178}$ Saskia Sassen, "Making Public Interventions in Today's Massive Cities". Disponível em: $<$ http://public.citymined.org/UrbanPlatform/PDF/saskia_sassen_2006.pdf>. Acesso em: 6 de novembro de 2013. 


\title{
REPENSAR A INFRAESTRUTURA
}

Infraestruturas tradicionalmente responderam por necessidades físicas em grande escala na cidade para o bom funcionamento operativo da cidade: transporte, iluminação, água e esgoto. Tais estruturas ocupam um lugar significativo no solo urbano, sem prover nada mais além do que a sua função primordial. Um exemplo clássico de tal uso são os piscinões em São Paulo que engoliram uma faixa significativa do solo urbano sem necessariamente retribuir com um benefício para a vida local da comunidade na sua superfície, criando paisagens desoladas sem nenhum caráter humano. Repensar infraestrutura significa que tais estruturas podem ser articuladas com as demais políticas setoriais e novos usos podem ser embutidos ao uso original das infraestruturas. Redefinindo o poder da infraestrutura mmbb arquitetos propõe a sua reinvenção:

\begin{abstract}
A velocidade da urbanização das metrópoles brasileiras tornou inócua grande parte das tentativas de se ordenar a produção do ambiente construído, o que mantém como pauta a delimitação do campo possível de ação dos arquitetos. Algumas hipóteses focam o projeto da infra-estrutura urbana, uma vez assumidos o seu valor público e o seu caráter sistêmico. Há uma potencialidade no projeto da infra-estrutura que, inserida na cidade pela forma difusa de uma rede, identifica e constrói, pontualmente, os elementos que reverberem na reconfiguração do sistema ao qual pertence. 0 que sugere uma estratégia possível de intervenção na metrópole... $A$ construção de uma rede de vazios urbanos é um fato em São Paulo que pode ser convertido em uma oportunidade de difusão de uma nova rede de espaços públicos. Essa ação demanda uma investigação de inserção urbana que permita a transposição de algumas das fronteiras da nossa metrópole, ao redefinir as superfícies de contato entre a infraestrutura e a localidade, aportando ao espaço construído um valor de morada. ${ }^{179}$
\end{abstract}

Uma nova vocação para as infraestruturas consolidam-se quando os novos programas respondem às necessidades evidentes de mais espaço público e áreas de lazer na cidade, adequando-se à paisagem e conectando-se com a vida cotidiana pública em sintonia com a vida doméstica. Exemplos significativos de tais proposições são os projetos Vazios de Água e Projeto Urbano Córrego do Antonico de MMBB e Hidroanel de Alexandre Delijaicov, André Takiya e Milton Braga. Estes projetos investem substancialmente no poder da arquitetura em transformar infraestruturas em espaços públicos vivazes e dignos, em relação com o restante da cidade, verdadeiras praiapaisagens.

${ }^{179}$ MMBB arquitetos, "Vazios de água”. Projeto ganhador do prêmio "Best Entry” na III Bienal de Roterdã em 2007. Disponível em: <http://www.mmbb.com.br/documents/essays/page/2>. Acesso em: 26 de fevereiro de 2014. 


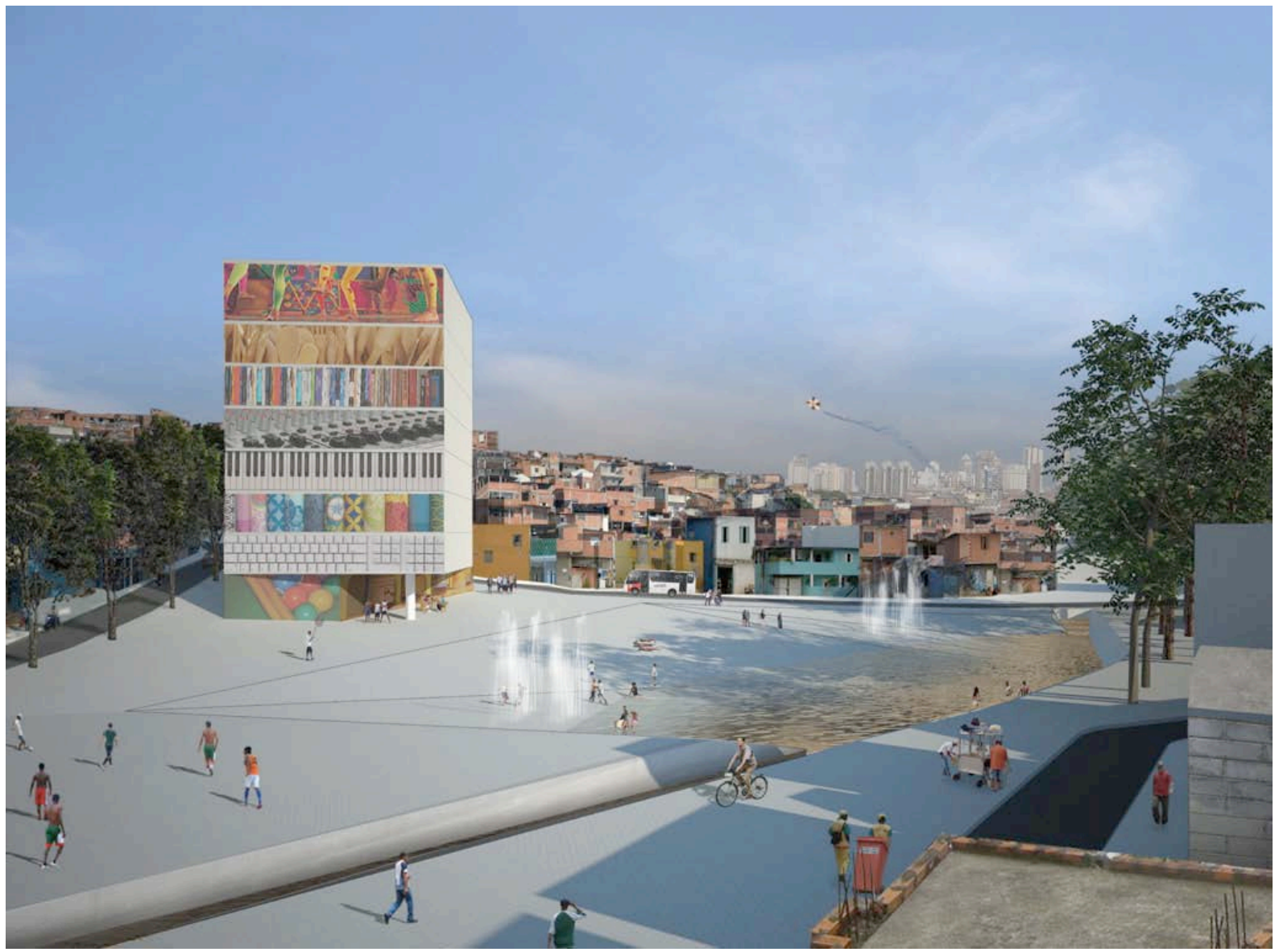

MMBB Arquitetos, Projeto Urbano Córrego do Antonico, Paraisópolis, São Paulo (2009)

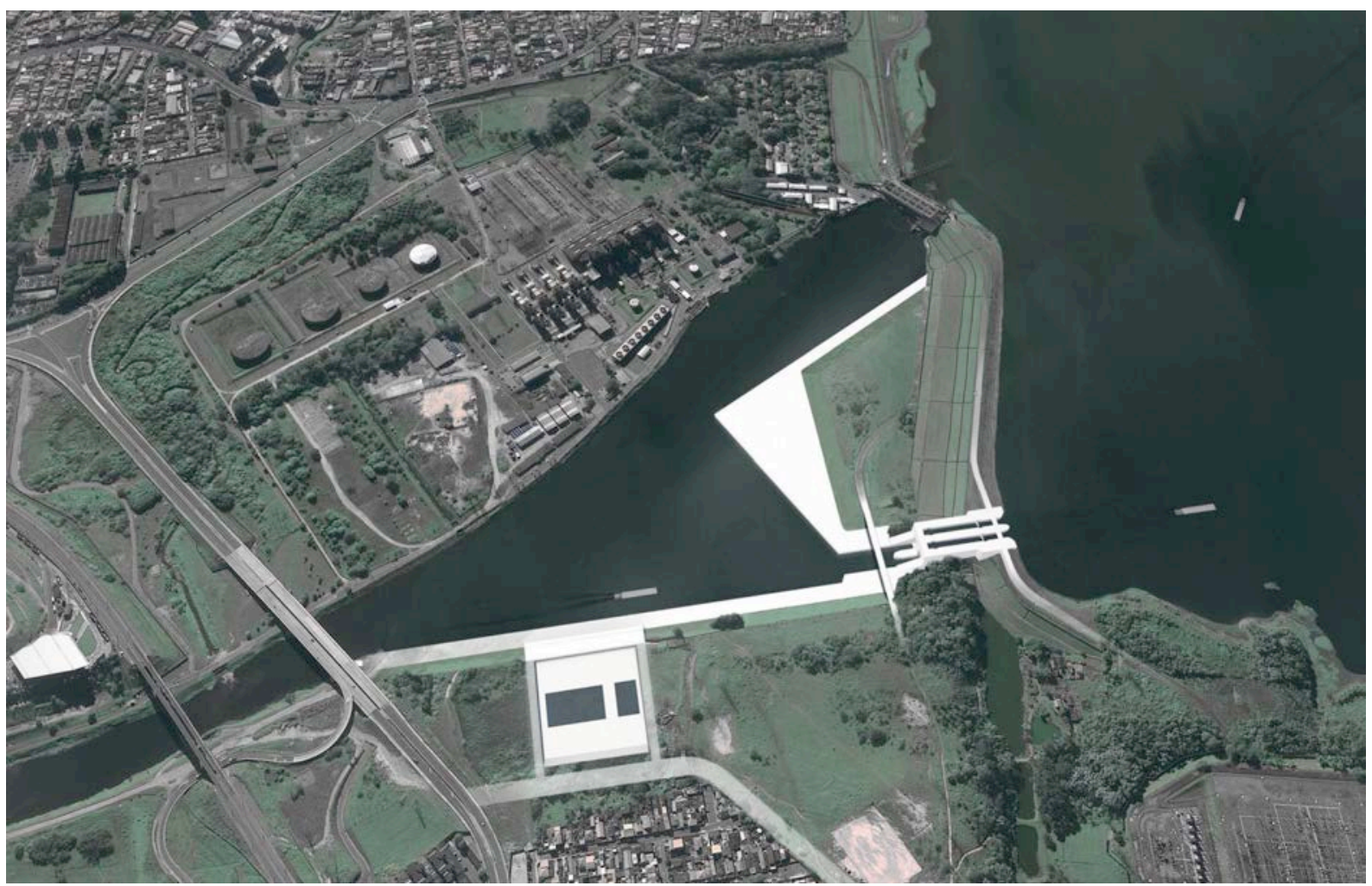

Alexandre Delijaicov, André Takiya e Milton Braga, Hidroanel, São Paulo (2012) 
Através de uma série de constatações, categorizações, e sugestões em torno do conceito de praiapaisagem articulados aqui, esperamos revelar uma nova consciência para os espaços públicos da cidade negociados pelo potencial dinâmico que as suas superfícies oferecem a partir da experiência da praia. Em uma época em que a grande questão urbana é exatamente o desenvolvimento infraestrutural - “a grande resolução urbana” — desafiamos com praiapaisagem as ações das administrações, do poder público, da massa política e da máquina corporativista das nossas cidades a não se aterem somente às preciosidades do capitalismo de investimentos, mas a responderem às necessidades humanas, físicas e culturais de uma nova metrópole.

A metrópole contemporânea está em crescimento perene, onde o congestionamento urbano mostra-se como um dos problemas mais pontuais, sempre carente de fluxos, multiplicidades e escoamentos, onde as redes de sistemas existentes se tornam rapidamente insuficientes, demandando os expedientes necessários para a reorganização radical da vida metropolitana. E como na metrópole as oportunidades de reinvenção gradualmente diminuem por força do seu crescimento precipitado, as superfícies suspensas (terrain vague) bem como as mais utilizadas pedem a sua própria reinvenção, buscando assim um melhor equilíbrio das dinâmicas urbanas. A idéia da reconstrução do lugar começa nas suas potencialidades, nas oportunidades que as infraestruturas urbanas oferecem para a arquitetura e o espaço público. Os específicos procedimentos de desenho propostos aqui, baseados nos antecedentes da praia, não se limitam a estes mas sugerem uma reflexão contínua destas dinâmicas. Juntos estes procedimentos almejam uma visão mais humanista do território urbano, ensejando devolver a cidade aos seus cidadãos, habitando-a em contentamento e celebração. Praiapaisagem aponta para uma possível direção em resposta à cidade em transformação. 


\title{
IV_Leça de Palmeira I 0 encontro derradeiro entre arquitetura e a praia
}

\author{
Sei que nós, os que vamos à praia, [...] vamos sempre mais ou menos atrás da mesma \\ coisa: das marcas do que o mundo era antes que a mão do homem decidisse \\ reescrevê-lo. Antes - mas talvez depois também. Porque a praia, espaço \\ escatológico por excelência, reúne em sua fisionomia de tábula rasa os valores de \\ uma era primitiva, anterior à história, e todos os traços de um cenário póstumo, que \\ uma catástrofe natural ou o impacto de uma força aniquiladora teriam reduzido ao \\ mais elementar: uma paisagem de restos e escombros microscópicos. A praia é ao \\ mesmo tempo o que esteve antes e o que veio depois, o princípio e o fim, o ainda \\ intacto e o já arrasado, a promessa e a nostalgia. ${ }^{180}$
}

Na elocução do escritor argentino Alan Pauls sobre a sua experiência com a praia restam o início e o fim, e ambos encontram-se na praia: o começo de tudo (no caso do Brasil, bem certo), o fim de tudo (uma paisagem apocalíptica). Para Pauls, a praia é um lugar interior onde a memória atiça as mais profundas marcas, como se praia revelasse o melhor amigo a quem se confia tudo. A praia então não é somente um destino ao prazer mas também ativa o pensamento, a introspecção, um equilíbrio que tentamos aqui na descoberta de praiapaisagem. Propomos então que a praia seja primordialmente um espaço-entre - não só nas suas dinâmicas urbanas, mas também na mais profunda experiência do indivíduo: entre o observar e a imaginação, entre a introspecção e a sociabilidade, entre a fenomenologia e a economia, entre a realidade e a mitologia.

Nas acepções entre praia (objeto) e praiapaisagem (proposição), são os atributos não quantificáveis que sustentam a possibilidade de um outro desenho, a possibilidade de uma outra vida na cidade, mais próxima dos nossos desejos. Então se começamos estas observações pelas mais diretas observações da praia como simples objeto - da areia, do mar, das pessoas, do calçadão, das canções - chegamos em seu desenlace com um desejo de focalizar naquilo que de mais primordial praiapaisagem representa. Para tanto, um projeto-praia da maior relevância posiciona-se no cerne da discussão apresentada aqui pela sua capacidade de sintetizar muitos dos conceitos desenvolvidos em praiapaisagem: as Piscinas das Marés de Leça da Palmeira, em Matosinhos (Porto, Portugal), de autoria de Álvaro Siza.

${ }^{180}$ Alan Pauls, A vida descalço, São Paulo: Cosac Naify, 2013. 


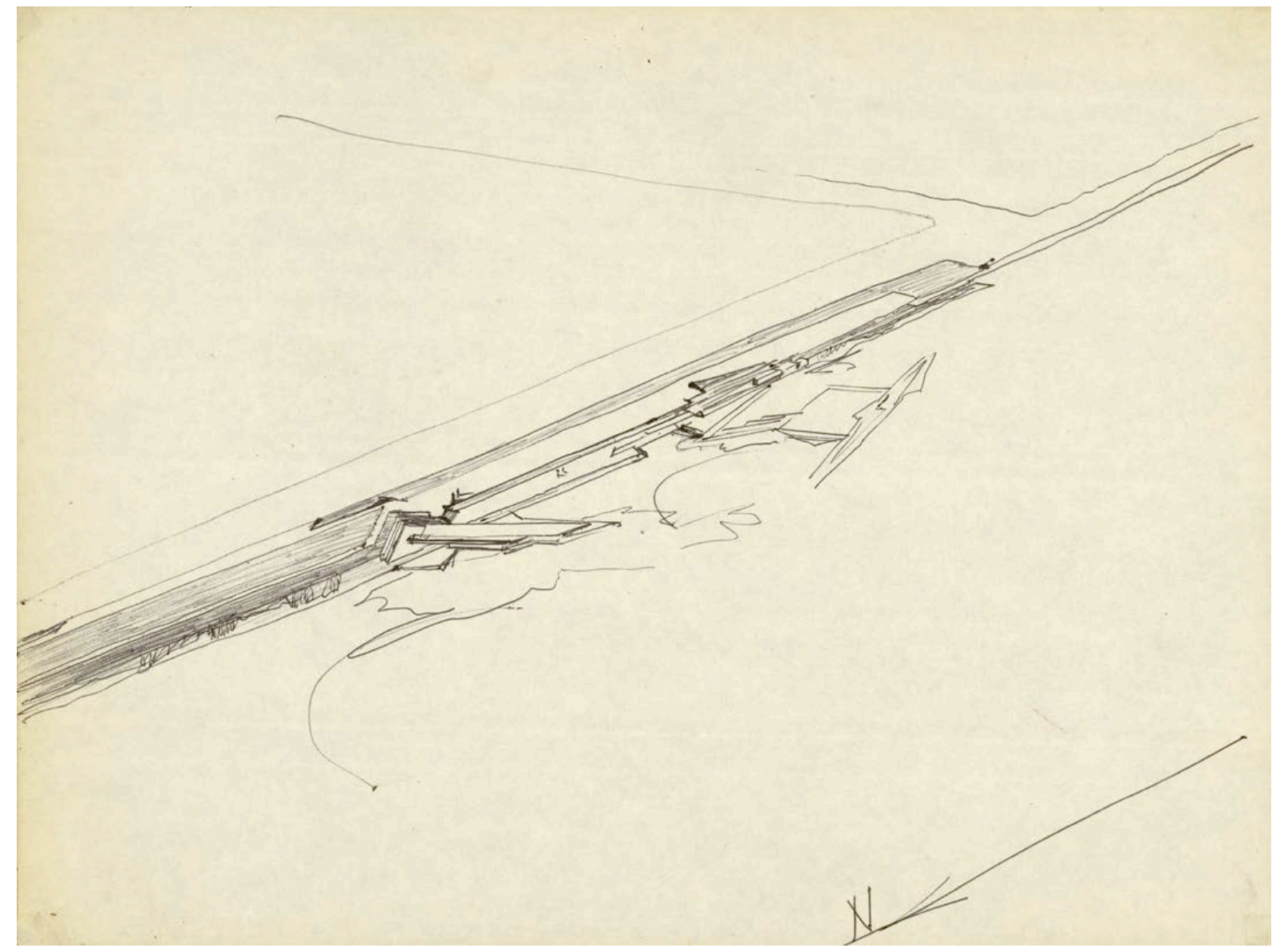

Álvaro Siza, Piscinas das Marés, Leça da Palmeira, croquis (1959)

O projeto foi iniciado pelo engenheiro Bernardo Ferrão em 1959 como uma infraestrutura local para se criar uma piscina numa encosta ríspida no litoral praiano ao norte da cidade do Porto. A intenção era estabelecer uma transição entre a cidade e o mar, utilizando-se de uma piscina natural de água salgada para acomodar confortavelmente os banhistas. Álvaro Siza foi posteriormente convidado para articular os aspectos urbanos do projeto, bem como para projetar os edifícios do balneário (vestiários) e redefinir a presença do tanque principal em relação ao conjunto, processo este que levou por volta de quatorze anos.

As Piscinas de Leça, construídas por entre as rochas, funcionam em resposta à maré alta, sistema este que, passivo, permite um saneamento natural da água sem qualquer outro método mecânico de purificação. A sua implantação usufruiu ao máximo dos desafios topográficos da escarpa, bem como da presença dos agressivos rochedos. Tanto o tanque principal como as piscinas secundárias foram cuidadosamente desenhados em resposta aos meticulosos espaços gerados entre os rochedos. 


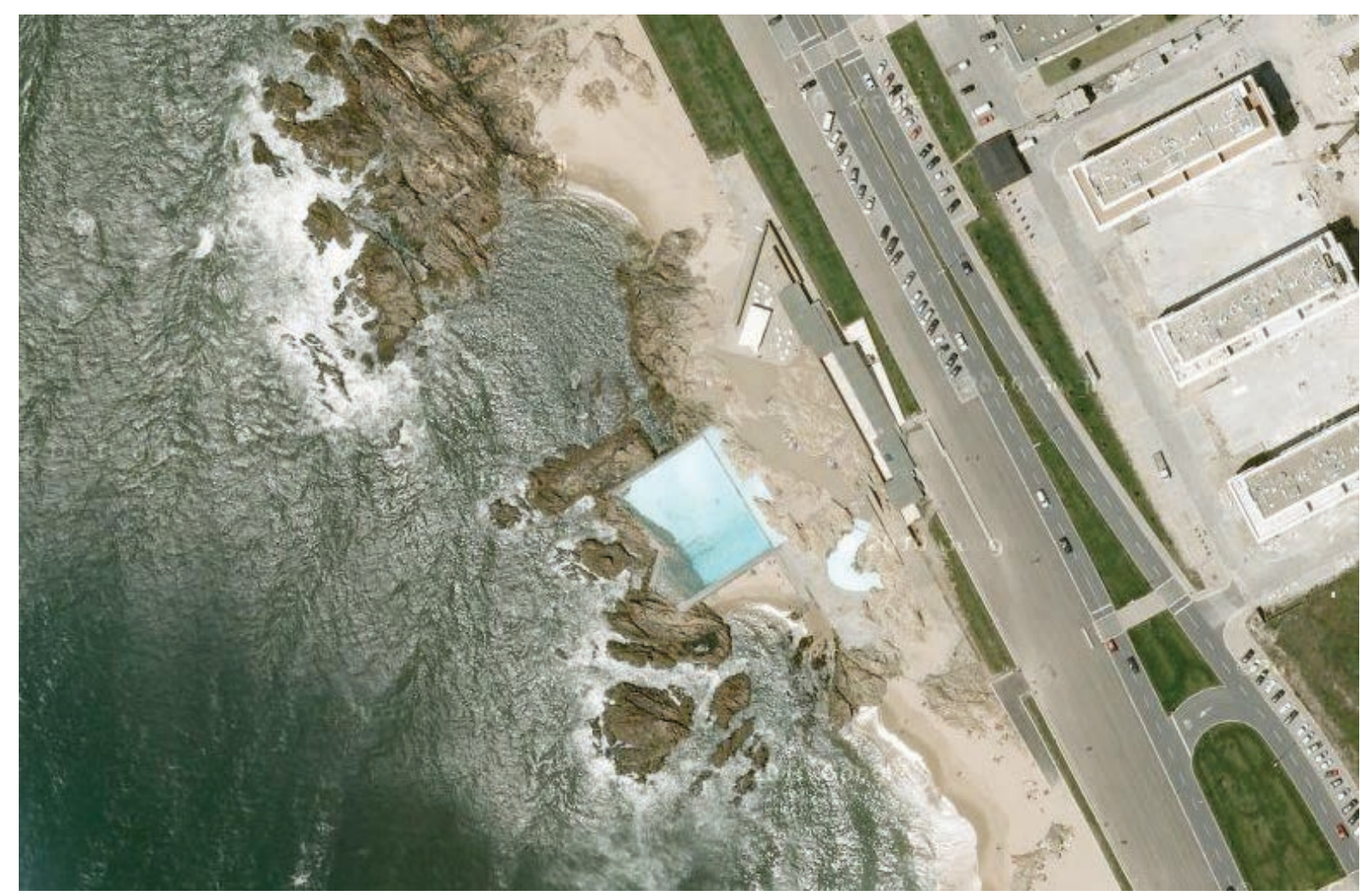

Álvaro Siza, Piscinas das Marés, Leça da Palmeira, vista aérea (1959-73)

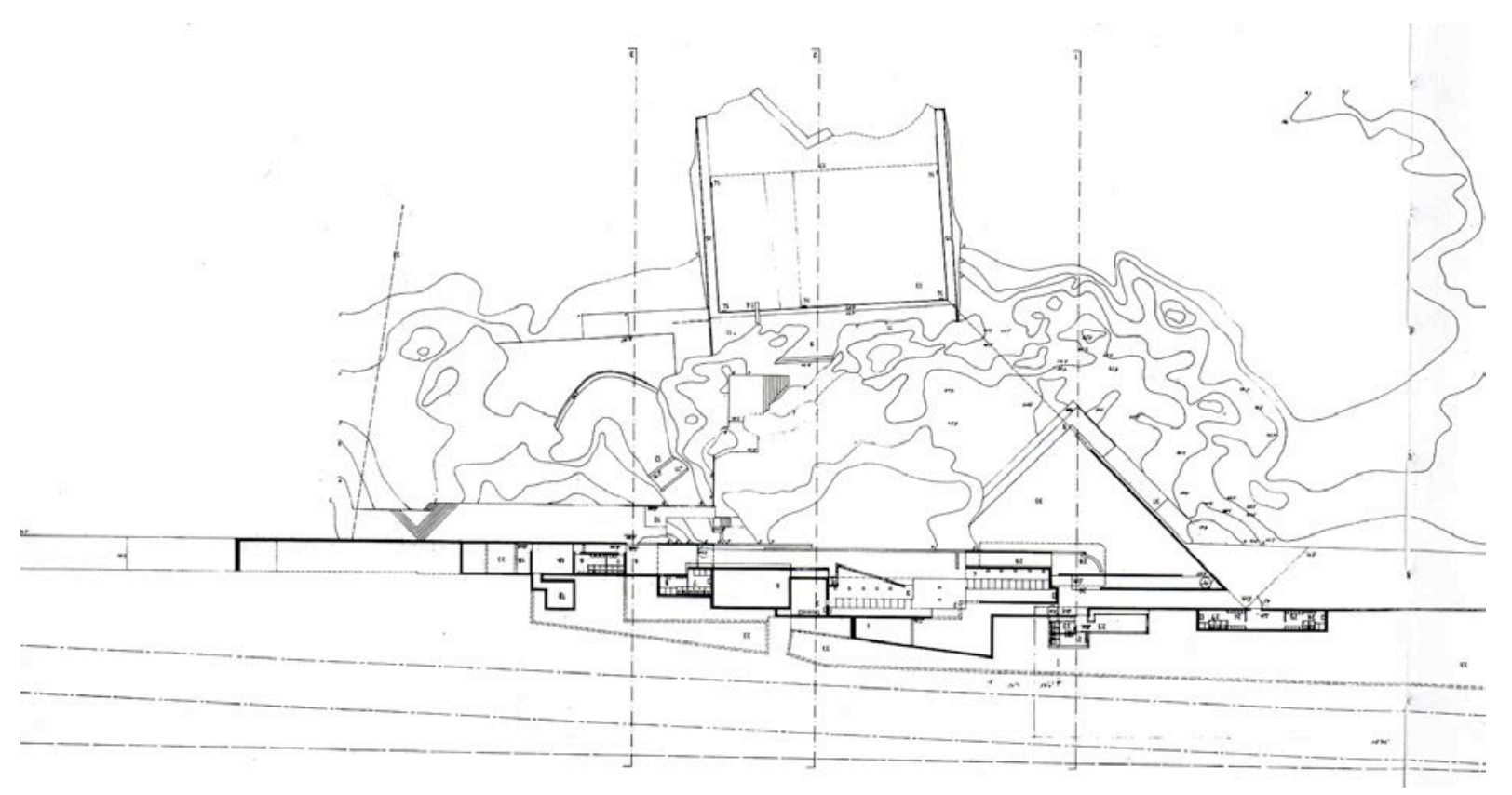

Álvaro Siza, Piscinas das Marés, Leça da Palmeira, planta (1959-73)

Para resolver a dissonância entre esta paisagem aparentemente agressiva e a cidade, $o$ gesto urbanista de Siza introduziu um muro linear ao longo da praia, negociando a sua relação com a Avenida Liberdade. Se de um lado o muro serviu de referência para o estacionamento 
de veículos e do passeio público, do lado da praia o muro virou a espinha dorsal da organização dos espaços e da sua circulação. Nota-se que o muro nunca ultrapassa em sua altura a linha do horizonte do mar adiante. A arquitetura do balneário, com os seus vestiários e lanchonete, é comprimida na topografia do terreno no nível da avenida e seus acessos negociados através de uma rede de rampas e corredores. O rigor da implantação valorizou enormemente o caráter espontâneo da paisagem e preservou a relação mais evidente entre a cidade e a praia: ao invés de criar uma ruptura entre os dois a arquitetura vira um convite sutil ao mistério e ao prazer do mar, camuflando o edifício e preservando a vista plena adiante para aquele que aborda o lugar pela cidade.

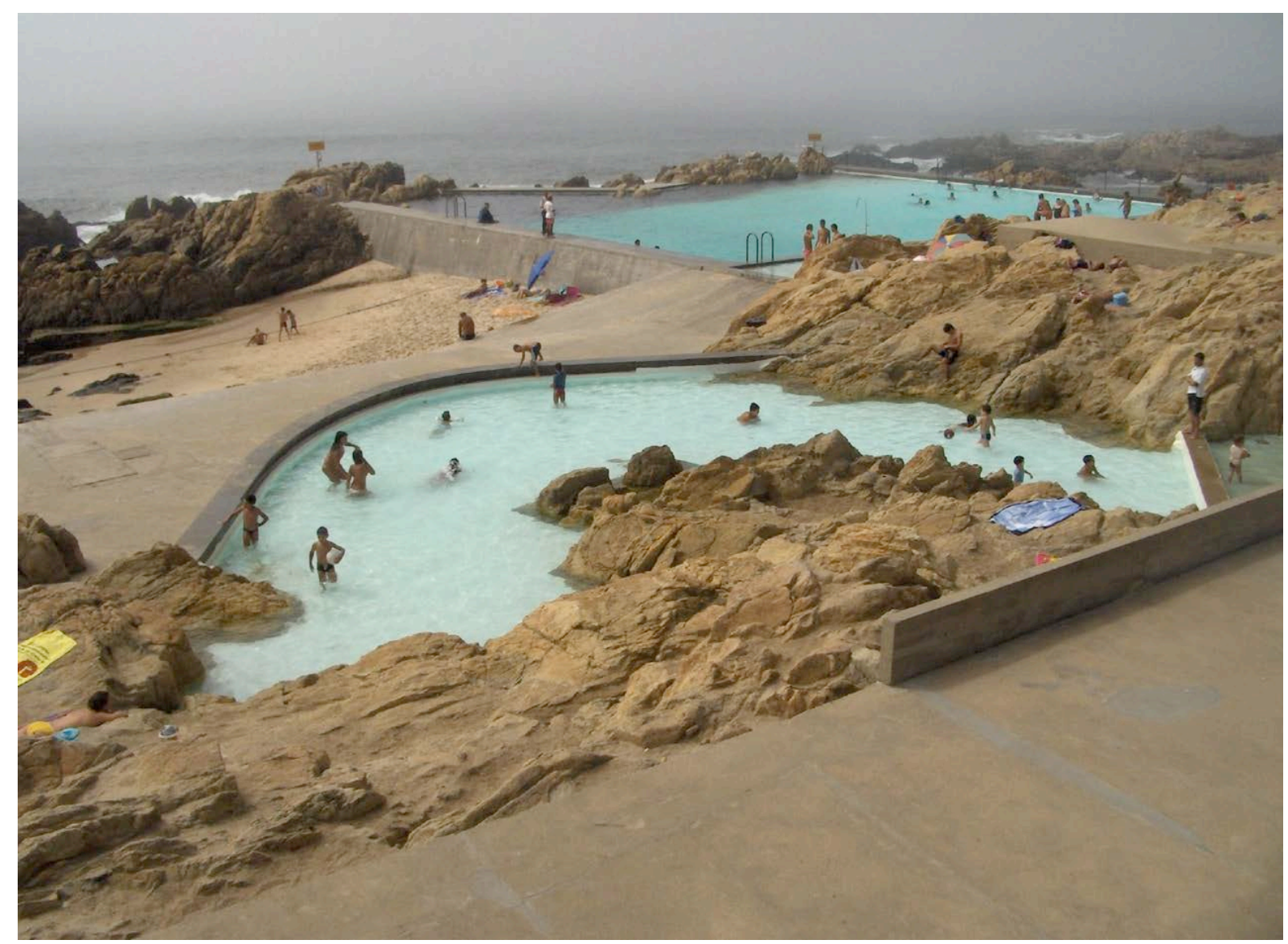

Álvaro Siza, Piscinas das Marés, Leça da Palmeira, vista geral (1959-73) 


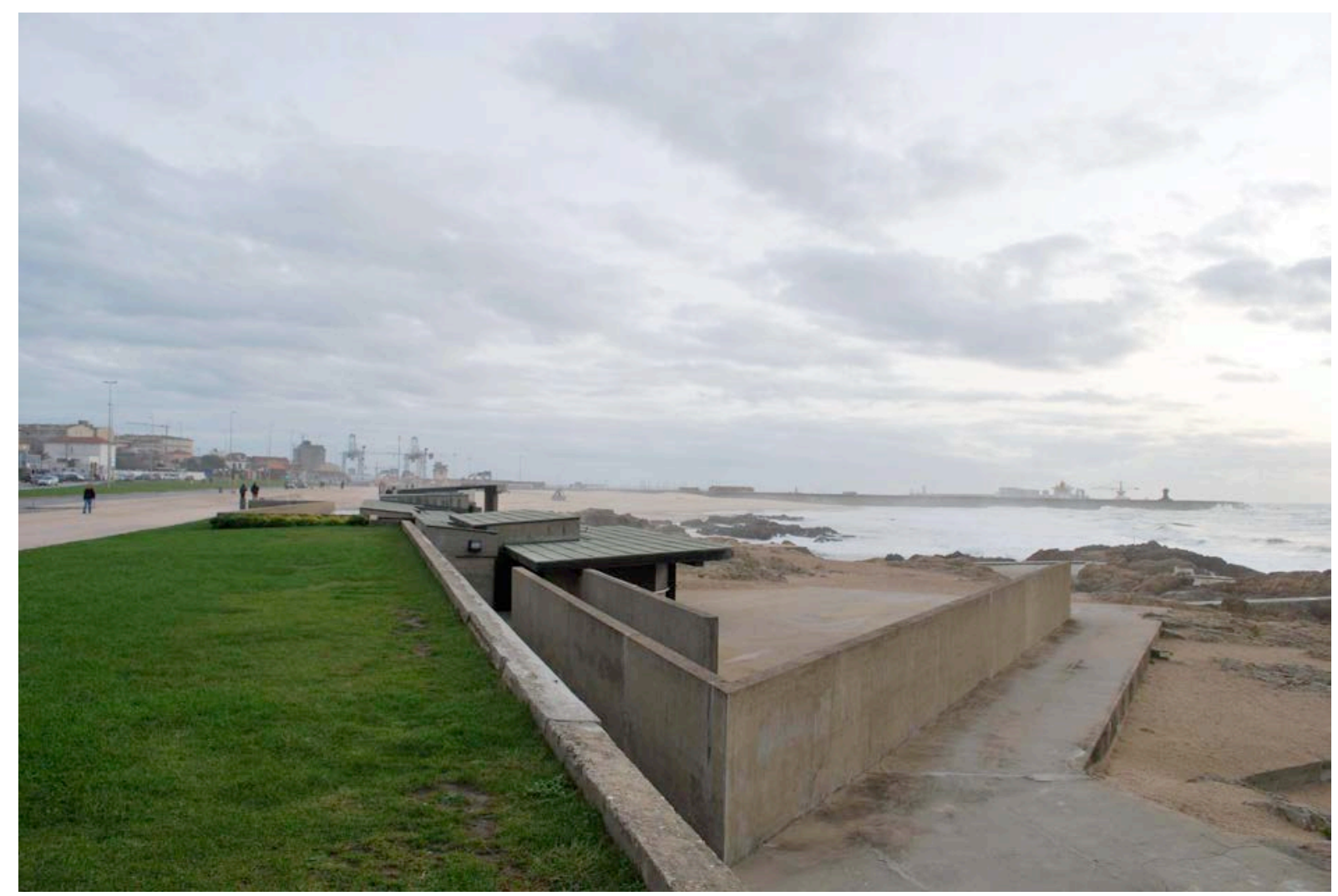

Álvaro Siza, Piscinas das Marés, Leça da Palmeira (1959-73)

Dentro dos procedimentos de desenho de Siza, praiapaisagem se manifesta na interlocução entre a praia, a paisagem e a cidade. Na sua sensibilidade, Siza reconhece a importância da dissolução da arquitetura, do seu próprio desaparecimento em prol de uma experiência única com a paisagem. A escolha de materiais, tão congruente aos materiais naturalmente presentes no lugar, atesta também ao desejo de construir um só território, uma só entidade, em uníssono - cidade-edifício-paisagem. O concreto armado, utilizado nas elevações de todo o edifício, dos corredores aos elementos de circulação (rampas e escadas), e também no longo muro estruturador, é essencialmente formado pela agregação de cimento, pedras e areia: a geologia da praia. Os corredores e rampas são articulados em uma forma complexa na sua gradual progressão por uma não-linearidade, pelo enquadramento estratégico de vistas, e pela baixa invasão de luz externa no interior da arquitetura, aludindo assim ao mistério de um ambiente natural não controlado, uma floresta, uma ruína, uma caverna. A cobertura é resolvida pela utilização de um material mais leve, uma madeira escura. Então, em sua natureza aparente e ilusória, os materiais manifestam-se na arquitetura através da experiência dos sentidos, e na consciência, como se a arquitetura e a paisagem 
fossem uma mesma coisa, como se a arquitetura não estivesse lá, como se a arquitetura fosse a própria paisagem, síntese esta explicitada por Álvaro Siza:

\begin{abstract}
Nestes primeiros trabalhos foi germinando a sensação irreprimível e determinante de que a arquitetura não termina em ponto algum, vai do objeto ao espaço e, por consequência, à relação entre os espaços, até ao encontro com a natureza. ${ }^{181}$
\end{abstract}

Esta ideia da arquitetura como construção do lugar aproxima as Piscinas de Leça com a proposta de Paulo Mendes da Rocha para a baía de Montevidéu. A proposta é de uma grande praça aquática, redesenhando as suas margens em uma forma quadrada, que organiza uma nova articulação urbana nas margens da cidade. Tal gesto é análogo à grande piscina de Leça: uma forma euclidiana que apresenta uma lógica contraditória em relação às formas orgânicas da costa (ou das margens da baía de Montevidéu), mas delineia-se como se fosse a escolha mais natural, inteligente. Como Siza e Ferrão, Mendes da Rocha transforma tanto o espaço como a paisagem através de um procedimento radical de desenho, um traço claramente moderno - ao invés de se propor simplesmente uma forma primária e automática, a consequência última é exatamente a proposta de uma nova maneira de viver e conviver na cidade.

As Piscinas das Marés de Leça da Palmeira tipificam a epítome da conjunção do homem com o mar, ritualizando o momento, traduzindo através da arquitetura o significado maior deste encontro derradeiro. Esta dimensão maior da arquitetura, que constrói um lugar com a visão aberta para o mundo, da ação do mundo em si e de si no mundo, é o que praiapaisagem propõe, pois a praia, sem fazer muito, constrói o tudo que uma vida compartilhada requer: uma vida junto, num espaço público comum, com dignidade, memória, celebração e significado.

Tal como Pauls, Caymmi sempre projetou a praia como o início de tudo (quem vem pra beira do mar / nunca mais quer voltar), na inauguração de uma vida ou de uma poesia, também entendeu que a praia é o destino derradeiro do ser humano (é doce morrer no mar / nas ondas verdes do mar). No conto "O piano" de Aníbal Machado, os desejos, o drama e a

${ }^{181}$ Álvaro Siza Vieira. Immaginare l'Evidenza. Roma-Bari: Laterza, 1998, p. 19. 


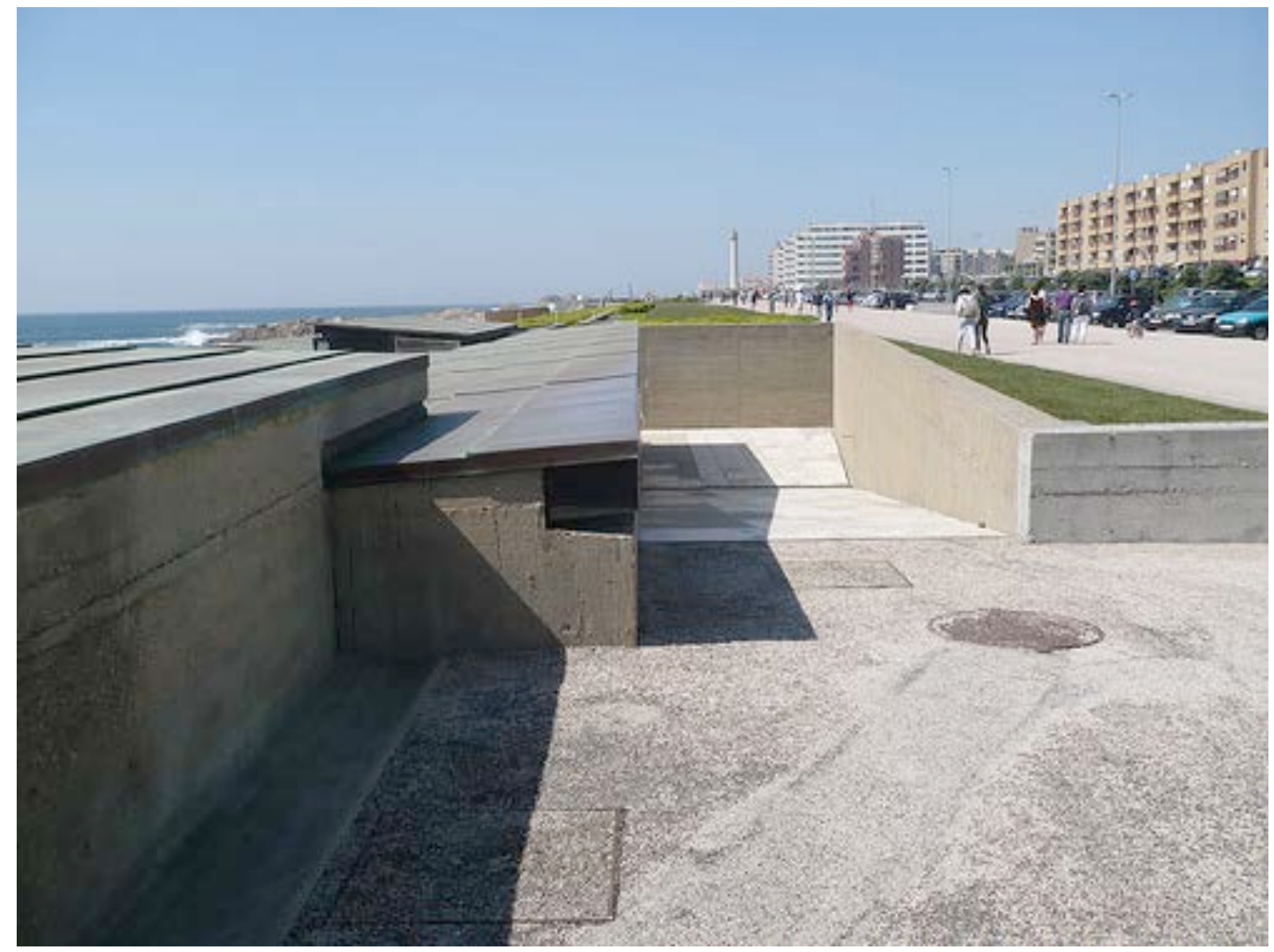

Álvaro Siza, Piscinas das Marés, Leça da Palmeira, entrada (1959-73)

lutas de uma família são acompanhados por um piano que participa das suas vidas aparentemente plácido, num canto, como se estivesse apenas observando. Mas quando o seu destino final acabou sendo a praia, e da praia o desconhecido mar, foi quando a realidade da sua presença demonstrou-se evidente para aqueles que compartilharam uma vida inteira na sua companhia, sustentados pela sua música e pela sua majestosa presença física. Pela reflexão se reconhece na história o fator essencial na formação de uma cultura. Pela experiência compartilhada se conhece o verdadeiro valor das relações humanas. É no espaço público em que tais relações se desenvolvem. Então porque não almejar espaços públicos tão atraentes, sedutores, aconchegantes como a praia, que promovem firmemente um ideal de uma sociedade mais humana? Praiapaisagem oferece proposições que contribuem para a resolução dos grandes desafios nos territórios públicos das nossas cidades, aspirando a espaços mais humanos e responsivos perante à complexa condição urbana contemporânea. 


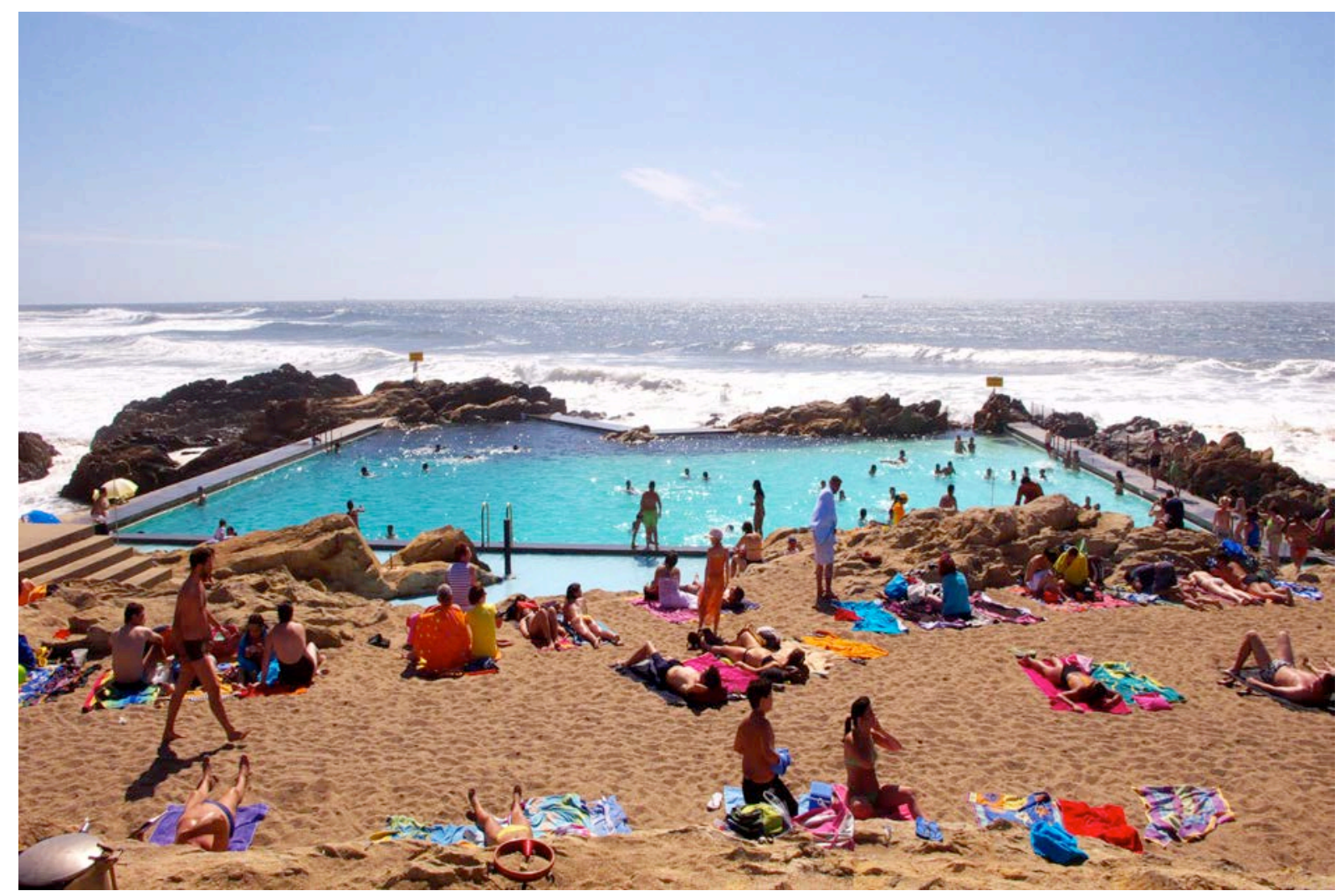

Álvaro Siza, Piscinas das Marés, Leça da Palmeira (1959-73) 
10_REFERÊNCIAS BIBLIOGRÁFICAS

\section{I_LIVROS}

ALLEN, Stan. Points + Lines. New York: Princeton Architectural Press, 1999.

ALLEN, Stan; MCQUADE, Marc. Landform Building: Architecture's New Terrain. Zurique: Lars Muller Publishers, 2011.

ALMY, Dean [org.]. On Landscape Urbanism. Austin: The University of Texas, 2007.

ANTÔNIO. João. Ô, Copacabana! São Paulo: Cosac Naify, 2001.

APPADURAI, Arjun. Modernity at large: cultural dimensions of globalization. Minneapolis: University of Minnesota Press, 1996.

------. Dimensões Culturais da Globalização: A modernidade sem peias. Lisboa: Teorema, 1996.

AQUINO, Eduardo; SHANSKI, Karen. Complex Order: intrusions in public space. Winnipeg: Plug In Editions, 2009.

ARTIGAS, Rosa [org.]. Paulo Mendes da Rocha. São Paulo: Cosac Naify, 2000.

ASHBERY, John, Self Portrait in a Convex Mirror. New York: Penguin Books, 1990.

AZEVEDO, Ricardo Marques de. Metrópole: Abstração. São Paulo, Perspectiva, 2006.

BACHELARD, Gaston. A Poética do Espaço. São Paulo: Martins Fontes, 2008.

BARILLI, Renato. Curso de Estética. Lisboa: Editorial Estampa, 1994.

BATTCOCK, Gregory [org.]. Minimal art: a critical anthology. New York: E. P. Dutton, 1968.

BENJAMIN, Walter. The Arcades Project. Cambridge, MA: Belknap Press of Harvard University Press, 2002.

------. Charles Baudelaire: A Lyric Poet in the Era of High Capitalism. London, Verso, 1997.

BOURRIAUD, Nicolas. Relational Aesthetics. Dijon: Les Presse Du Reel, 1998.

BOZO, Dominique, Yves Klein 1928-1962: A Retrospective, Institute for the Arts. Houston: Rice University, 1982.

BRAGA, Rubem. Ai de ti, Copacabana. Rio de Janeiro: Record, 2009.

BRAND, Jan e JANSELIJN, Han, Architectuur en Verbeelding (Voorwoord). Zwolle: Uitgeverij Waanders, 1989.

BRETT, Guy; OITICICA, Hélio. Hélio Oiticica. Londres: Whitechapel Gallery, 1969.

BRETT, Guy. Brasil Experimental: arte/vida, proposições e paradoxos. Rio de Janeiro: Contra Capa, 2005.

BRITO, Ronaldo. Neoconcretismo: vértice e ruptura do projeto construtivo brasileiro. Rio de Janeiro: FUNARTE, 1985.

BROUWER, Joke; BROOKMAN, Philip; MULDER, Arjen. TransUrbanism. Rotterdam: NAi Publishers, 2002. 
BUCK-MORSS, Susan. The dialectics of seeing: Walter Benjamin and the Arcades project. Cambridge, MA: The MIT Press, 1991.

BUDNEY, Jen; BLACKWELL, Adrian. Unboxed: Engagements in Social Space, Ottawa, Gallery 101, 2005.

BURLE MARX, Roberto. Arte e Paisagem (conferências escolhidas). São Paulo: Editora Nobel, 1987.

CARERI, Francesco. El andar como práctica estética. Barcelona: Gustavo Gili, 2002.

CAVALCANTI, Lauro et al. Roberto Burle Marx: The Modernity of Landscape. Paris: Institut français d'architecture/Actar, 2011.

CORBIN, Alain. The Lure of the Sea: The Discovery of the Seaside 1750-1840. Penguin Books, 1995.

CORNER, James [org.]. Recovering Landscape: Essays in Contemporary Landscape Architecture. New York: Princeton Architectural Press, 1999.

COUTINHO, Wilson. Copacabana, cidade eterna: 100 anos de um mito. Rio de Janeiro: Relume Dumará, 2001.

DAVIDSON, Cynthia D. Anyplace. New York: Any Corporation / Rizzoli, 1995.

DAVIDSON, Cynthia D. Anything. Cambridge, MA: The MIT Press, 2001.

DE CERTEAU, Michel. The Practice of Everyday Life. California: University of California Press, 1984.

DELEUZE, Gilles; GUATTARI, Félix. A Thousand Plateaus: Capitalism and Schizophrenia. Minneapolis: University of Minnesota Press, 1987.

DERCON, Chris [org.]. Hélio Oiticica. Rotterdam: Witte de With, center for contemporary art, 1992.

FAWCETT, Fausto. Copacabana Lua Cheia (Série Coleção Sebastião). Rio de Janeiro: Dantes Editora, 2001.

FAVARETO, Celso. A invenção de Hélio Oiticica. São Paulo: Edusp, 1992.

FIGUEIREDO, Luciano; OITICICA, César; FILHO, César Oiticica. Hélio Oiticica: penetráveis. Rio de Janeiro: Centro Cultural Hélio Oiticica, 2008.

FOSTER, Hal. The Anti-Aesthetic: Essays on Postmodern Culture. Seattle: Bay Press, 1983.

FOUCAULT, Michel. Society Must be Defended: Lectures at the Collège de France, 1975-76 (7th January 1976). London: Picador, 1983.

FRAMPTON, Kenneth. Megaform as Urban Landscape. Ann Arbour: University of Michigan, 1999.

GALOFARO, Luca. Artscapes: el arte como aproximación al paisaje contemporáneo. Barcelona: Gustavo Gili, 2002.

GASPAR, Claudia Braga. Orla carioca: história e cultura. São Paulo: Metalivros, 2004.

GREENBERG, Clement. Art and Culture Critical Essays Boston: Beacon Press.

GULLAR, Ferreira. Experiência neoconcreta. São Paulo: Cosac Naify, 2007.

------. Dentro da noite veloz. Rio de Janeiro: José Olympio, 1967. 
HAJER, Maarten; REIJNDORP, Arnold [org.]. In Search of New Public Space: Analysis and Strategy. Rotterdam: NAi Publishers, 2001.

HARRISON, Charles; WOOD, Paul J. Art in Theory 1900-2000: An Anthology of Changing Ideas. Hoboken, NJ: Wiley-Blackwell, 2002.

HABERMAS, Jurgen. The structural transformation of the public sphere: An inquiry into a category of bourgeois society. Cambridge, MA: MIT Press, 1989.

HOBBS, Robert. Robert Smithson: Sculpture. Ithaca: Cornell University Press, 1981.

HOLLEVOET, Christel; JONES, Karen; NYE, Timothy. The Power of the City, the City of Power. New York: The Whitney Museum of American Art, 1992.

HOLT, Nancy [org.]. The Writings of Robert Smithson. New York: New York University Press, 1979.

HOLTZMAN, Harry; JAMES, Martin S. The New Art-The New Life: The Collected Writings of Piet Mondrian. Boston: G. K. Hall \& Co., 1986.

IBELINGS, Hans. Supermodernism. Rotterdam: NAi Publishers, 2003.

JAMESON, Fredric. Postmodernism, or, The Cultural Logic of Late Capitalism, London: Verso, 1991.

KNABB, Ken, Situationist International Anthology. Berkeley: Bureau of Public Secrets, 1982.

KOOLHAAS, Rem. Delirious New York: A Retroactive Manifesto for Manhattan. New York: Monacelli, 1997.

KOOLHAAS, Rem. S,M,L,XL. New York: The Monicelli Press, 1995.

KWON, Miwon. One Place after Another: Site Specific Art and Locational Identity. Cambridge, MA: The MIT Press, 2004.

JACOBS, Jane. The Death and Life of Great American Cities. New York: Knopf Doubleday, 1992.

LACAN, Jacques. The Language of the Self. Baltimore: The Johns Hopkins University Press, 1956.

LACY, Suzanne. Mapping the Terrain: New Genre Public Art. Seattle: Bay Press, 1994.

LEACH, Neal. Re-thinking Architecture: A Reader in Cultural Theory. London, Routledge, 1997.

LEFEBVRE, Henri. The Production of Space. New York: Wiley-Blackwell, 1992.

LEFEBVRE, Henri, Writings on Cities. Malden: Blackwell Publishers, 2000.

LENCEK, Lena; BOSKER, Gideon. The Beach: The History of Paradise on Earth. Viking, New York, 1998.

------. Beach: Stories by the Sand and Sea. Cambridge, MA: Da Capo Press, 2000.

LIPPARD, Lucy R. Overlay: Contemporary Art and the Art of Prehistory. New York: New Press, 1995.

------ . The Lure of the Local: Senses of Place in a Multicentered Society. New York: New Press, 1998. 
LINS E SILVA, Flávia; KALLMAN, Daniela. Faixa de areia: um filme sobre as praias do Rio. Rio de Janeiro: Focus Filmes, 2007 [filme].

MAAK, Niklas. The Architect on the Beach. Munique: Hirmer Verlag, 2011.

MARTINS, Carlos. A Paisagem carioca. Rio de Janeiro: MAM, 2000.

MOREIRA, Inês, Petit Cabanon. Porto: Dafne (opúsculo 7), 2007

MASI, Domenico de. Ócio Criativo. São Paulo: Editora Sextante, 2000.

MOSTAFAVI, Mohsen; NAJLE, Ciro. Landscape Urbanism: A Manual for the Machinic Landscape. London: AA Publications, 2004.

MULDER, Arjen. "The Right to Participate in the Work of Imagination" (Entrevista com Arjun Appadurai). Transurbanism. Rotterdam: NAi Publishers, 2002.

OITICICA, Hélio. Aspiro ao grande labirinto. Rio de Janeiro: Rocco, 1986.

PAULS, Alan. A vida descalço, São Paulo: Cosac Naify, 2013.

PEIXOTO, Nelson Brissac. Paisagens urbanas. São Paulo: Editora Marca D'Água, 1996.

PETIT, Jean. Le Corbusier Lui-même. Genebra: Rousseau, 1970.

RENDELL, Jane. Art and Architecture: A Place Between. Londres: I. B. Tauris, 2007.

ROCHA, Glauber [Orlando Senna, org.]. Roteiros do terceyro mundo. Rio de Janeiro: Alhambra/Embrafilme, 1985.

ROCHA, Glauber. Revolução do cinema novo. São Paulo: Cosac Naify, 2004.

RUBY, Ilka; RUBY, Andreas. Groundscapes: El reencuentro com el suelo em la arquitectura contemporânea. Barcelona: Gustavo Gili, 2006.

SADLER, Simon. The Situationist City. Cambridge, MA: The MIT Press, 1998.

SANTOS, Milton. Técnica, espaço, tempo: globalização e meio técnico-científico informacional. São Paulo: Hucitec, 1994.

------. A natureza do espaço: espaço e tempo: razão e emoção. São Paulo: Hucitec, 1999.

SASSEN, Saskia ; DE CAUTER, Lieven ; DEHAENE, Michiel ; URRY, John. Power: Producing the Contemporary City. Rotterdam: NAi Publishers, 2007.

SENNETT, Richard. The fall of public man. New York: Knopf, 1977.

------. Flesh and Stone: The Body and the City in Western Civilization. New York: W.W. Norton \& Co., 1996.

SEUPHOR, Michel. Abstract Painting. New York: Dell Publishing Co., 1964.

SIMMEL, Georg. The Sociology of Georg Simmel. London: Mcmillan, 1950.

SIZA, Álvaro. Piscina na praia de Leça de Palmeira [1959-1973]. Lisboa: Blau, 2004.

SIZA, Álvaro. Immaginare l'Evidenza. Roma-Bari: Laterza, 1998.

SMITHSON, Alison et al. Team 10 Primer. Cambridge, MA: The MIT Press, 1974.

SOLÀ-MORALES, Ignasi de. Differences: Topographies of Contemporary Architecture. Cambridge, MA: The MIT Press, 1996.

SOLNIT, Rebecca. Wanderlust: A History of Walking. New York: Penguin, 2000. 
TEMPORARY SERVICES. Public Phenomena: Informal Modifications of Shared Spaces. Temporary Services: Chicago, 2005.

WALDHEIM, Charles. The Landscape Urbanism Reader. New York: Princeton Architectural Press, 2006.

WALVIN, James. Beside the Seaside: A Social History of the Popular Seaside Holiday. London: Allen Lane, 1978.

WITTGENSTEIN, Ludwig. Philosophical Investigations. New York: MacMillan, 1953.

WOMACK, Chloé; BROOME, Brennan (ed.). Doing Our Homework: Documents on Infrastructure and Collaboration in Social Practice. Windsor: Broken City Lab, 2012.

XAVIER, Ismail. Sertão Mar: Glauber Rocha e a estética da fome. São Paulo: Cosac Naify, 2007.

\section{II_ARTIGOS E TESES}

AURELI, Pier Vitorio, "Toward the Archipelago: Defining the Political and the Formal in Architecture.” New York: Log Journal 11, 2008, pp. 91-119.

CASTELLS, Manuel. “The Space of Flows”. The Rise of the Network Society. Oxford: Blackwell, 2000, p. 407-459.

DaMATTA, Roberto. "Na praia, a reforma da sociedade". O Globo, Rio de Janeiro, p. 7, 25 jan. 2006.

DANTAS, Eustógio Wanderley Correia. Maritimidade nos trópicos: por uma geografia do litoral. Fortaleza: UFC Edições, 2009.

FARDY, Jonathan R. Double Vision: Reviewing Man Ray and Marcel Duchamp's 1920 PhotoText (tese de mestrado). Faculty of Arts, Bowling Green State University. Bowling Green, $\mathrm{OH}$ : 2008.

FREEMAN, James. "Great, good, and divided: the politics of public space in Rio de Janeiro". Journal of Urban Affairs, v. 30, n. 5, p. 529-556. Hoboken, NJ: Wiley, 2008.

------. "Democracy and Danger on the Beach: Class Relations in the Public Space of Rio de Janeiro". Space and culture, vol. 5 no. 1, fevereiro. Thousand Oaks, Calif.: Sage Publications, 2002, pp. 9-28.

GODFREY, Brian J.; ARGUINZONI, Olivia M. "Regulating Public Space on the Beachfronts of Rio de Janeiro". New York: The Geographical Review 102 (1), pp. 17-34, January 2012.

HARTLEY, John. "The public sphere on the beach". European Journal of Cultural Studies, v. 9, n. 3, p. 341-362, Thousand Oaks, CA: SAGE Publications, 2006.

INGERSOLL, Richard. “The Death of the City and the Survival of Urban Life”. Simpósio Urban Traumas: The City and Disasters [7 a 11 de julho de 2004, palestra]. Disponível em: http://urban.cccb.org/urbanLibrary [16/05/2007]

OBRADOR-PONS, Pau. "A haptic geography of the beach: naked bodies, vision and touch". New York: Social \& Cultural Geography, v. 8, n. 1, fev. 2007, p. 123-141. 
------. "Building Castles in the Sand: Repositioning Touch on the Beach". The Senses and Society, v. 4, n' 2, p. 195-210, 2009.

REESER, Amanda Lawrence; Schafer, Ashley, “Re: Programming”, Praxis (Journal of writing and building), número 8. Cambridge, Mass.: Praxis, 2006.

TELLES, Sophia da Silva. Arquitetura Moderna no Brasil: o desenho da superfície. São Paulo: FFLCH-USP (Dissertação de mestrado), 1988.

TRAINOR, James, "Walking the Walk: the Artist as Flâneur". Winnipeg: Border Crossings Magazine, no. 88, 2003, pp. 82-92.

\section{III_WEBGRAFIA}

a.h.s. boy. Coletânea online de textos de autoria de autores situacionistas. $<$ http://www.nothingness.org/SI >. (12 de outubro de 2011).

BARBOSA, Antônio Agenor. "Copacabana em música”. Vitruvius, Minha Cidade, 4 de outubro de 2003. <http://www.vitruvius.com.br/revistas/read/minhacidade/04.039/2035>. (12 de novembro de 2012).

BERENSTEIN JACQUES, Paola. "Elogio aos errantes: Breve histórico das errâncias urbanas" (2004). <http://www.vitruvius.com.br/arquitextos/arq000/esp256.asp.> (18 de fevereiro, 2012).

BUFORD, Bill. Revista Granta, "Dirty Realism” (1983). <http://www.granta.com/Archive/8>. (16 de junho de 2012).

CAYMMI, Dorival. “Quem vem pra beira do mar”. <http://letras.mus.br/dorivalcaymmi/688632>. (12 de julho de 2013).

e Carlos Guinle, “Sábado em Copacabana”. <http://www.letras.com.br/\#!dorivalcaymmi/sabado-em-copacabana>. (21 de junho de 2012).

CHRISTO \& Jean-Claude. “Artworks". <http://www.christojeanneclaude.net/fe.html>. (23 de julho de 2011).

DE MASI, Domenico. Ócio Criativo.

$<$ http://www.domenicodemasi.it/pt/paradigma/\#oziocriativo>. (10 de agosto de 2013).

FLORIANO, Cesar, "Passeio de Copacabana: uma referência da arte pública de Roberto Burle Marx", Artigo apresentado no $8^{\circ}$ Seminário Docomomo Brasil (2009).

$<$ http://www.docomomo.org.br/seminario\%208\%20pdfs/159.pdf $>$. (11 de janeiro de 2014).

GULLAR, Ferreira. "Entrevista a Weydson Barros Leal", Jornal da Poesia.

$<$ http://secrel.com.br/jpoesia/gular01.html>. (3 de outubro de 2011).

------. "Corpo a corpo com a linguagem".

$<$ http://portalliteral.terra.com.br/ferreira_gullar/porelemesmo>. (23 de junho de 2011).

------. "Entrevista a Caco Xavier e grupo. Disponível em:

$<$ http://www.casadobruxo.com.br/poesia/f/fgullarent.htm $>$. Acessado em: 14 de julho de 2010. 
KIPNIS, Jeffrey. Discrimination, Palestra na Escola de Arquitetura da Universidade Harvard. $<$ http://www.gsd.harvard.edu/\#/media/discrimination-by-jeffrey-kipnis.html>. (7 de setembro de 2010).

MEIRELES, Cildo. “Glovetrotter 1991”, London: The Tate Gallery (2008-09).

$<$ http://www.tate.org.uk/whats-on/tate-modern/exhibition/cildo-meireles >. (13 de junho de 2010).

MENDES DA ROCHA. Paulo, "Paulo Mendes da Rocha Interview".

$<$ http://www.designboom.com/eng/interview/rocha.html>. (14 de abril de 2012).

MMBB Arquitetos. "Vazios de água” (2007).

<http://www.mmbb.com.br/documents/essays/page/2>. (26 de fevereiro de 2014).

MONDRIAN, Piet. "Café Society Downtown: mais boogie-woogie".

$<$ http://www.artmuseums.harvard.edu/mondrian/glossary.html>. (14 de julho de 2010).

OITICICA, Hélio. "Eu em Mitos Vadios”, Ivald Granato, (original de Oiticica de 1978).

$<$ http://www.itaucultural.org.br/aplicexternas/enciclopedia/ho/index.cfm?fuseaction=docume ntos\&cod $=462 \&$ tipo $=2>$. (8 de fevereiro 2012).

. "Delirium Ambulatorium”. Participação em Mitos Vadios de Ivald Granato,

Programa Hélio Oiticica, Itaú Cultural.

$<$ http://www.itaucultural.org.br/aplicexternas/enciclopedia/ho/index.cfm?fuseaction=docume ntos\&cod $=165 \&$ tipo $=2>$. (18 de maio de 2012).

PARDO, Jorge. "Press release de uma exposição na Galeria Gagosian".

<http://www.gagosian.com/exhibitions/2010-07-16_jorge-pardo>. (5 de julho de 2010).

RIBEIRO, Sólon. “Mitos Vadios”. <http://solonribeiro.multiply.com/journal/item/3>. (15 de junho de 2012).

RODRIGUES, Nelson. "Entrevista para o Ciclo de Teatro Brasileiro do Museu da Imagem e do Som" (Walmir Ayala, José Lino Grunewald, Fausto Wolff, Otto Lara Resende e Hélio Pellegrino). <http://www.nelsonrodrigues.com.br/site/comnelson_det.php?Id=16>. (14 de dezembro de 2013).

SASSEN, Saskia, "Imminent Domain: Saskia Sassen and Hans Haacke on the Spaces of Occupation". New York: Art Forum (janeiro de 2012).

$<$ http://artforum.com/inprint/id=29814>. (10 de abril de 2012).

SHAD. "What is the Occupy Movement?", The Vancouver Sun (21 de novembro de 2011). $<$ http://blogs.vancouversun.com/2011/11/21/shad-what-is-the-occupy-movement $>$. (11 de janeiro de 2012).

SPECTOR, Nancy. "Paired, Gold: Félix González-Torres and Roni Horn”, New York: Guggenheim Museum (2010). <http://www.guggenheim.org/newyork/exhibitions/past/exhibit/3155>. (3 de outubro de 2013). 


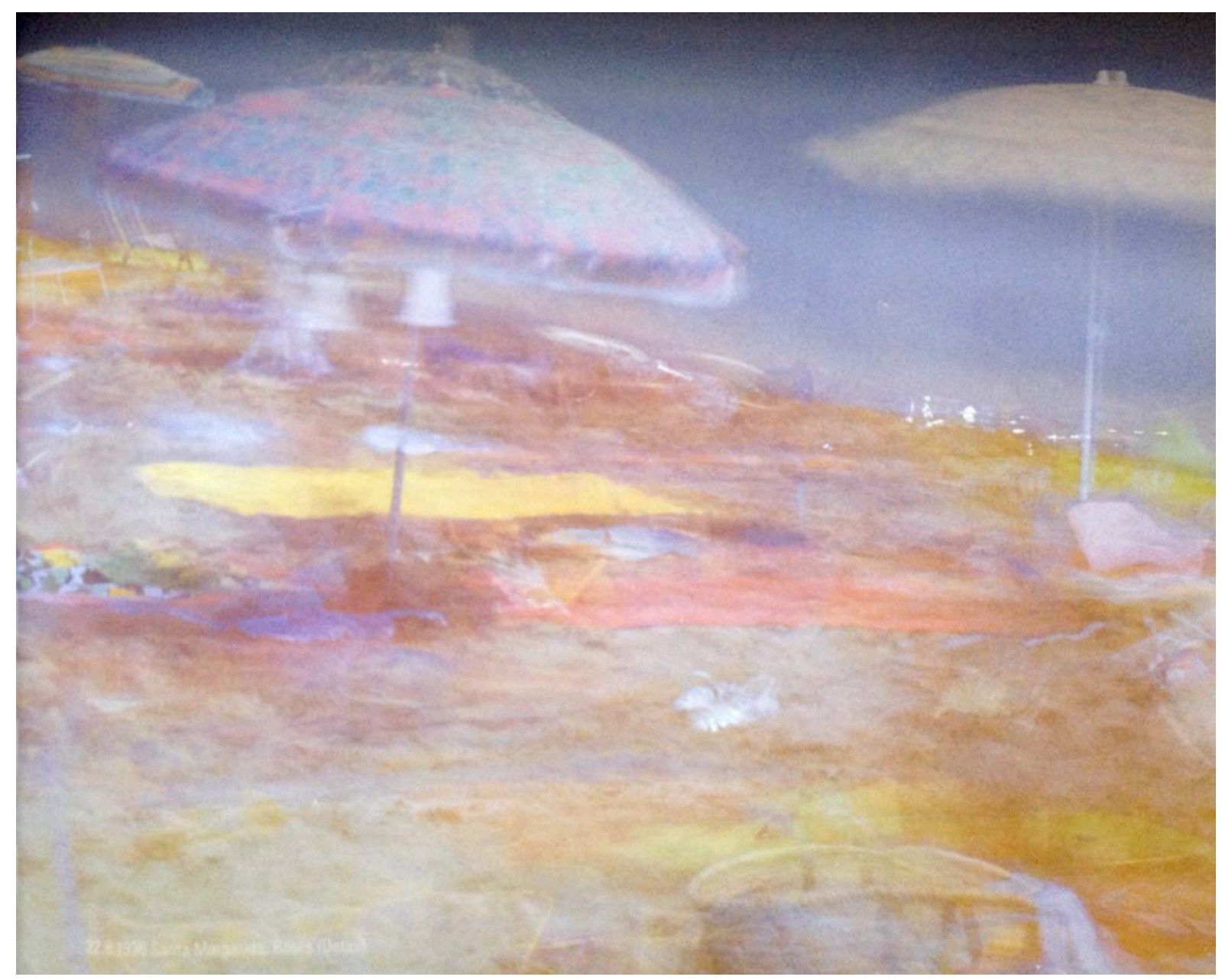

Michael Wesely, Praia Santa Margarida (1996) 